$x^{2}$
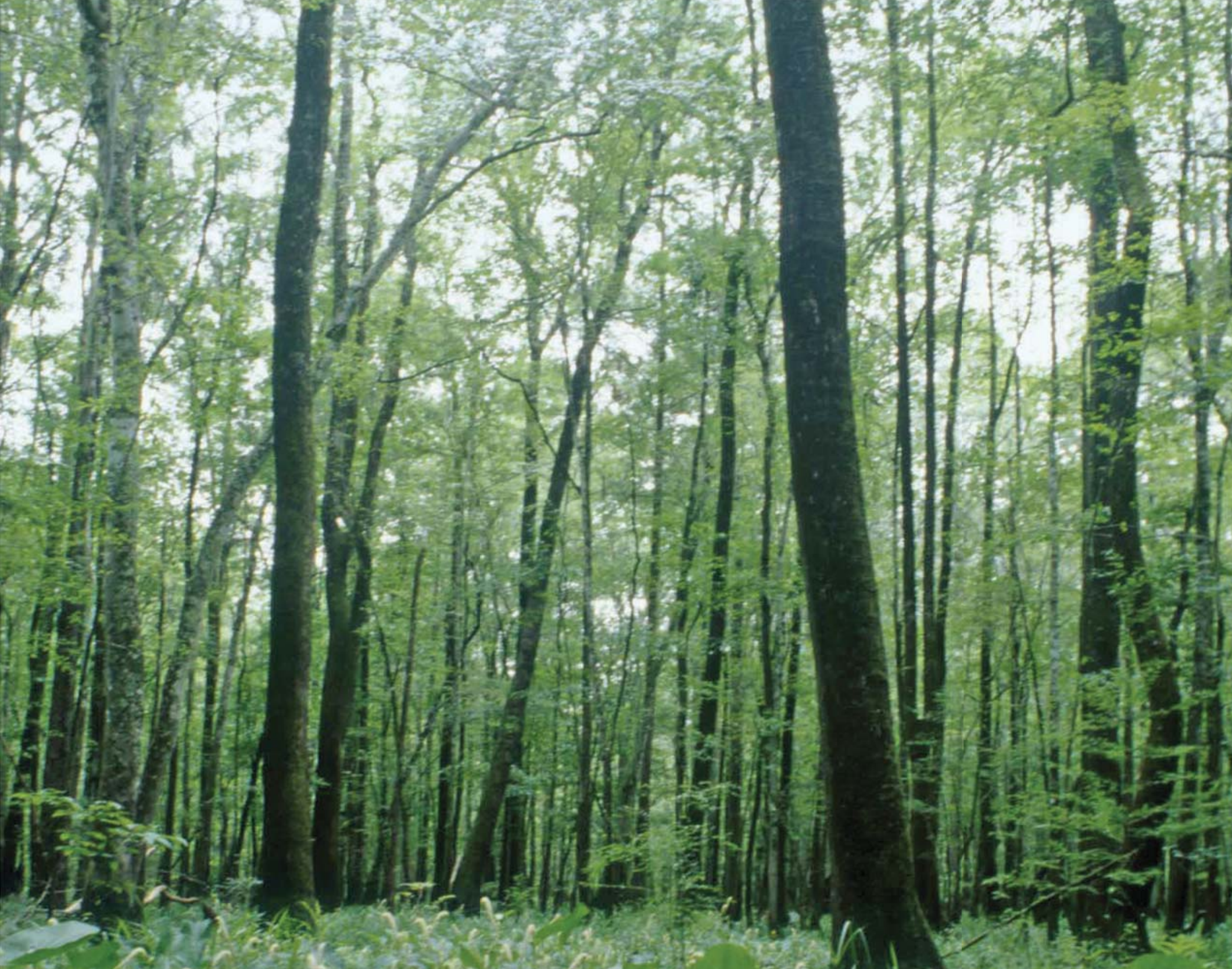

$\frac{3}{4}$
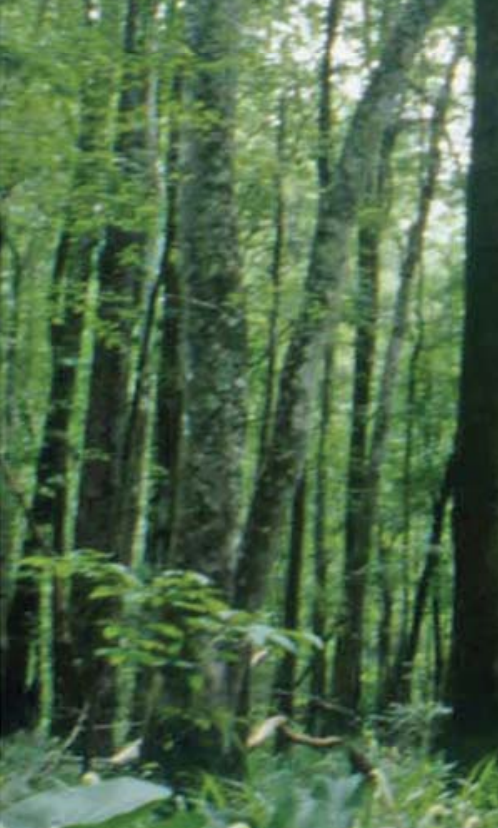

I.

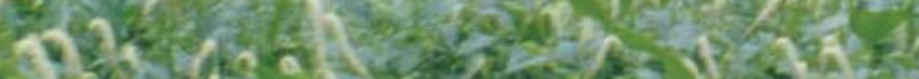


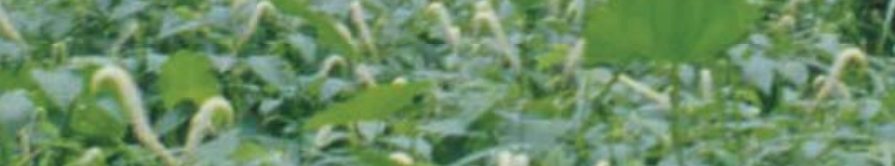

$+2,0,2$

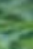

e

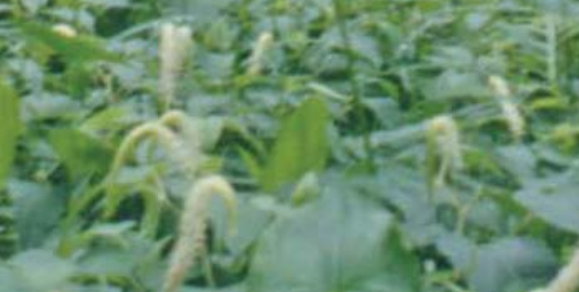

Savannah River Site

Environmental Report for 2012

Savannah River Nuclear Solutions, LLC 
Front Cover - David Scott of the Savannah River Ecology Laboratory (SREL) provided this year's cover photo. The photo was taken in the Mixed Swamp Forest Set-Aside, which is part of the Savannah River swamp. This Set-Aside is one of the original ten SREL habitat reserve areas selected in 1968 to represent a diversity of bottomland hardwood/ floodplain forest communities of a southern river swamp system. Represented are aquatic, semi-aquatic, and terrestrial habitats associated with cypress-tupelo ponds, mixed hardwood sloughs, and mixed hardwood ridges. This Set-Aside is important because seasonally flooded hardwood forests are becoming increasingly rare habitats that are particularly vulnerable to habitat destruction and/or alteration due to drainage, water control projects, industrial or urban waste discharge, or power plant cooling effluents. The flower in the foreground is called Lizard's Tail (Latin name Saururus cernuus). It grows in a variety of aquatic habitats, but on SRS it can be particularly abundant in some of the swamp forests.

For more information about this report, or to obtain additional copies, contact

Amy Meyer

Savannah River Nuclear Solutions, LLC

Building 735-B, Savannah River Site

P. O. Box A

Aiken, SC 29802-9969

Telephone: (803) 952-8660

E-mail address: Amy.meyer@srs.gov

This document was prepared in conjunction with work accomplished under Contract No. DE-AC09-08SR22470 with the U.S. Department of Energy. This work was conducted under an agreement with, and funded by, the U.S. Government. Neither the U.S. Government nor its employees, nor any of its contractors or subcontractors or their employees, makes any expressed or implied 1) warranty or assumes any legal liability for the accuracy or completeness - or for the use or results of such use - of any information, product, or process disclosed; or 2) representation that such use or results of such use would not infringe on privately owned rights; or 3) endorsement or recommendation of any specifically identified commercial product, process, or service. Any views and opinions of authors expressed in this document do not necessarily state or reflect those of the U.S. Government, or of its contractors or subcontractors. 


\section{Savannah River Site}

\section{Environmental Report for 2012}

Prepared by

Savannah River Nuclear Solutions, LLC

Savannah River Site

Aiken, SC 29808 



\section{ACKNOWLEDGEMENTS}

Sample Data Management acknowledges with deep appreciation the efforts of the following individuals, who provided valuable resources, information, technical data, management, administrative, field or other support to the Savannah River Site Annual Environmental Report for 2012:

$\begin{array}{llll}\text { Perry Allen } & \text { Jim Fudge } & \text { Jeff Lintern } & \text { David Scott } \\ \text { Mark Amidon } & \text { James Hall } & \text { Bill Littrell } & \text { Carl Shealy } \\ \text { Stephen Armstrong } & \text { John Harley } & \text { Bill Maloney } & \text { Ashley Shull } \\ \text { Rob Backer } & \text { Tim Hartley } & \text { Hugh Marberry } & \text { Dan Skiff } \\ \text { Charles Bishop } & \text { Duane Hoepker } & \text { Shelia McFalls } & \text { Paul South } \\ \text { Gerald Blount } & \text { David Hughey } & \text { John McGehee } & \text { Mark Spires } \\ \text { Nancy Brown } & \text { Ginger Humphries } & \text { Laureen McMurray } & \text { Rebecca Sturdivant } \\ \text { Bruce Boulineau } & \text { Jay Hutchinson } & \text { Grace Miller } & \text { Benjamin Terry } \\ \text { Vivian Cato } & \text { Rod Hutto } & \text { Winston Moore } & \text { Jeff Thibault } \\ \text { Joy Chapman } & \text { Paul Jolley } & \text { Hal Morris } & \text { Art Timms } \\ \text { Bob Craig } & \text { Thomas Kmetz } & \text { Karen Palmer } & \text { Cyndi Tindall } \\ \text { Sharon Crawford } & \text { Branden Kramer } & \text { Kathy Petty } & \text { Joan Toole } \\ \text { Daryl Doman } & \text { Bill Lewis } & \text { Jesse Pierce } & \text { Michele Wilson } \\ \text { Keith Dyer } & \text { Cheryl Lewis } & \text { Reginald Robinson } & \text { David Wolfe } \\ \text { Tim Faugl } & \text { Keith Liner } & \text { Jeff Ross } & \text { Kim Wolfe } \\ & & & \text { James Yascavage }\end{array}$

Special thanks to Taressa Barnes for providing expert word processing and design support.

Special thanks to David Scott of the Savannah River Ecology Laboratory (SREL) for providing the cover photo.

Special thanks to Emily Macdonald and Kevin Kytola of Sapere Consulting, Inc. for providing technical editing services.

Thanks to Rachel Baker, Roy Blackwell, and James Tussey for providing computer hardware and software support.

Marvin Stewart is acknowledged with appreciation for providing Internet expertise and computer software support. 
A special thanks to Gail Whitney for coordinating the DOE-SR review and approval process, which requires dedication and support from both DOE-SR and SRNS:

$\begin{array}{ll}\text { DOE-SR } & \text { NNSA } \\ \text { TimothyArmstrong } & \text { Christina Edwards } \\ \text { DeLisa Carrico } & \text { Gregg Nelson } \\ \text { Amy Caver } & \text { Jay Ray } \\ \text { Jeffrey Crenshaw } & \underline{\text { SRNS }} \\ \text { Geraldine Flemming } & \text { Dan Campbell } \\ \text { Candice Freeman } & \text { Tom Coughenour } \\ \text { James Gusti } & \text { Kevin Schmidt } \\ \text { Arthur Gould } & \text { USFS-SR } \\ \text { Andrew Grainger } & \text { Mark Cramer } \\ \text { Brian Hennessey } & \\ \text { Gary Hoover } & \\ \text { Maatsi Ndingwan } & \\ \text { Tony Polk } & \\ \text { Phillip Prater } & \\ \text { Dennis Ryan } & \\ \text { Bill Taylor } & \end{array}$

A special acknowledgement for our late friend and colleague, Mark Cramer, who passed away June 5, 2013, for his support of our efforts to produce a quality document for the Site. 


\section{TO OUR READERS}

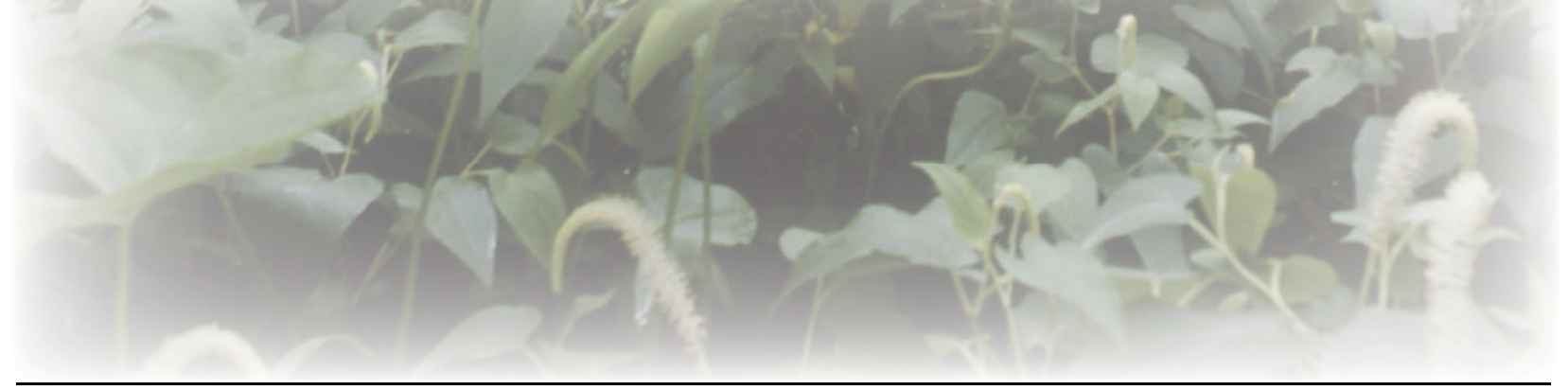

The Savannah River Site (SRS) has had an extensive environmental monitoring program in place since 1951 (before Site startup). In the 1950s, data generated by the onsite environmental monitoring program were reported in Site documents. Beginning in 1959, data from offsite environmental surveillance activities were presented in reports issued for public dissemination. SRS reported onsite and offsite environmental monitoring activities separately until 1985, when data from both programs were merged into one public document.

The Savannah River Site Environmental Report for 2012 (SRNS-STI-2013-00024) is an overview of effluent monitoring and environmental surveillance activities conducted on and in the vicinity of SRS from January 1 through December 31, 2012 - including the Site's performance against applicable standards and requirements. Details are provided on major programs such as the Environmental Management System (EMS) and permit compliance. Information for the 2012 report was compiled and prepared by the Environmental Compliance and Area Completion Projects (EC\&ACP) Department of Savannah River Nuclear Solutions, LLC (SRNS), the Site's management and operations (M\&O) contractor. The "Environmental Monitoring Program Management Plan" (SRS EM Plan, 2013) documents 1) the rationale and objectives for the monitoring program, 2) the frequency of monitoring and analysis, 3) the various sampling locations, and 4) the specific analytical and sampling protocols used. The "Environmental Monitoring Quality Assurance Project Plan" (SRS EM QA Plan, 2013) describes the associated quality assurance requirements.

Complete data tables are included on the $\mathrm{CD}$ inside the back cover of this report. The $\mathrm{CD}$ also features 1) an electronic version of the report; 2) an appendix of Site, environmental sampling location, dose, and groundwater maps; and 3) annual (2012) reports from a number of other SRS organizations. The data tables generally are presented as unformatted Excel spreadsheets; they are not intended to be printed. However, if printing is desired, the user can modify the "Page Setup" parameters in Excel as needed. If printing of the "SRS Maps" on the CD is desired, it is recommended (to ensure clarity) that figures be printed $8.5 \times 11$ inches.

The following information should aid the reader in interpreting data in this report:

- Variations in environmental report data reflect year-to-year changes in the routine monitoring program, as well as occasional difficulties in sample collection or analysis. Examples of such difficulties include adverse environmental conditions (such as flooding or drought), sampling or analytical equipment malfunctions, sample handling and transportation issues, and compromise of the samples in the preparation laboratories or counting room.

- Table heading abbreviations may include the following: 1) "N" is number of observations; 2) "Sample-Con" is sample concentration; 3) "SampleStd" is standard deviation; and 4) "Sig" is significance, with "Yes" meaning detectable and "No" meaning less than the analytical method detection limit. If the uncertainty (standard deviation) is large, the significance may also be set to "No."

- Analytical results and their corresponding uncertainty terms generally are reported with up to three significant figures. This is a function of the computer software used and may imply greater accuracy in the reported results than the analyses would allow.

- Units of measure and their abbreviations are defined in the glossary (beginning on page G-1) and in charts at the back of the report. The reported uncertainty of a single measurement reflects only the counting error, not other components of random and systematic error in the measurement process, so some results may imply a greater confidence than the determination would suggest. 
- An uncertainty quoted with a mean value represents the standard deviation of the mean value. This number is calculated from the uncertainties of the individual results. For an unweighted mean value, the uncertainty is the sum of the variances for the individual values divided by the number of individual results squared. For a weighted mean value, the uncertainty is the sum of the weighted variances for the individual values divided by the square of the sum of the weights.

- All values represent the weighted average of all acceptable analyses of a sample for a particular analyte. Samples may have undergone multiple analyses for quality assurance purposes or to determine if radionuclides are present. For certain radionuclides, quantifiable concentrations may be below the minimum detectable activity of the analysis, in which case the actual concentration value is presented to satisfy DOE reporting guidelines.

- The generic term “dose," as used in the report, refers to the committed effective dose (50-year committed dose) from internal deposition of radionuclides and to the effective dose attributable to beta/gamma radiation from sources external to the body.

\title{
Report Available on Web
}

\author{
Readers can find the \\ SRS Annual Environmental Report \\ on the World Wide Web at the following address: \\ http://www.srs.gov/general/pubs/ERsum/index.html.
}


Description $\quad$ Number

Acknowledgements .............................. iii

To Our Readers $\ldots \ldots \ldots \ldots \ldots \ldots \ldots \ldots \ldots \ldots \ldots \ldots \ldots \ldots \ldots \ldots$ iv

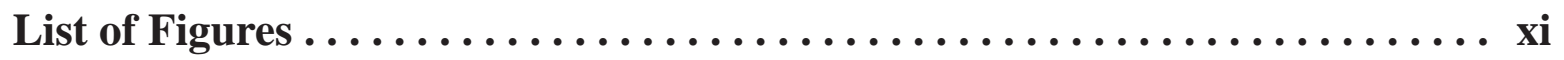

List of Tables $\ldots \ldots \ldots \ldots \ldots \ldots \ldots \ldots \ldots \ldots \ldots \ldots \ldots \ldots \ldots \ldots \ldots$

Abbreviations and Acronyms ....................... xvii

Sampling Location Information $\ldots \ldots \ldots \ldots \ldots \ldots \ldots \ldots \ldots \ldots \ldots$

Chapter 1 - Introduction $\ldots \ldots \ldots \ldots \ldots \ldots \ldots \ldots \ldots \ldots \ldots \ldots \ldots \ldots \ldots$

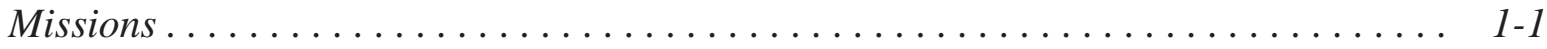

Organization ................................. 1-2

Site Locations, Demographics, and Environment . . . . . . . . . . . . . . 1-4

DOE EM Primary Site Activities . . . . . . . . . . . . . . . . . . . . 1-6

DOE NNSA Primary Site Activities . . . . . . . . . . . . . . . . 1-9

Chapter 2 - Environmental Management System . . . . . . . . . . . . . . . 2-1

SRS EMS Implementation . . . . . . . . . . . . . . . . . . . . 2-1

Sustainability Accomplishments . . . . . . . . . . . . . . . . . . 2-6

EMS Best Practices/Lessons Learned . . . . . . . . . . . . . . . . . . . . . . 2-12

Ongoing Environmental Enhancement Projects . . . . . . . . . . . . . . . . . . . . 2-14 
Description

Page

Chapter 3 - Compliance Summary . . . . . . . . . . . . . . . . . . . 3-1

Compliance Status . . . . . . . . . . . . . . . . . . . . . . 3-1

Environmental Restoration and Waste Management .................. 3-3

Radiation Protection . . . . . . . . . . . . . . . . . . . . . . . . 3-7

Air Quality and Protection . . . . . . . . . . . . . . . . . . . . . . . .

Water Quality and Protection . . . . . . . . . . . . . . . . . . . . . 3-10

Other Environmental Requirements . . . . . . . . . . . . . . . . . . . 3-11

DOE Orders/Executive Orders for Environmental Systems . . . . . . . . . . . . . . . 3-15

SRS Environmental Issues/Actions . . . . . . . . . . . . . . . . . . 3-16

Permits . . . . . . . . . . . . . . . . . . . . . . . . . . . . . 3-22

Chapter 4 - Effluent Monitoring $\ldots \ldots \ldots \ldots \ldots \ldots \ldots \ldots \ldots \ldots \ldots \ldots$ 4-1

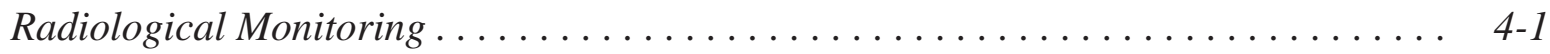

Nonradiological Monitoring . . . . . . . . . . . . . . . . . . . . . . . . 4-7

Chapter 5 - Environmental Surveillance . . . . . . . . . . . . . . . . . 5-1

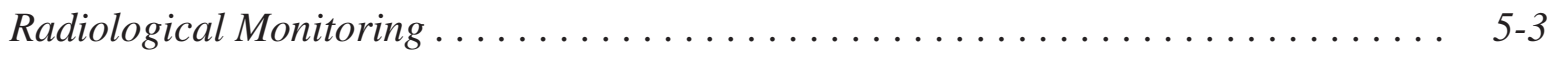

Nonradiological Monitoring . . . . . . . . . . . . . . . . . . . . 5-28

Chapter 6 - Radiological Dose Assessments . . . . . . . . . . . . . . . 6-1

What is a Dose? ............................ 6-1

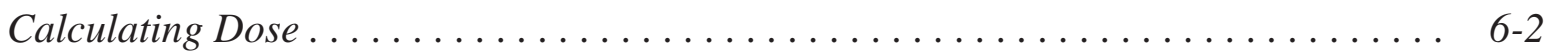

Dose Calculation Results . . . . . . . . . . . . . . . . . . . . . . 6-5

Release of Material Containing Residual Radioactivity . . . . . . . . . . . . . . . 6-16

Radiation Dose to Aquatic and Terrestrial Biota . . . . . . . . . . . . . . . . 6-17

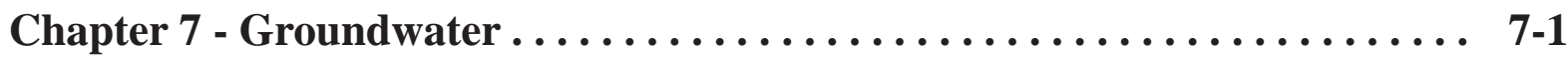

Groundwater Protection Program at SRS . . . . . . . . . . . . . . . . . 7-1

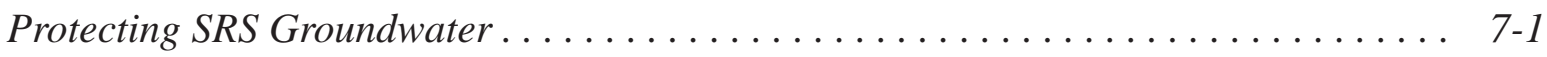

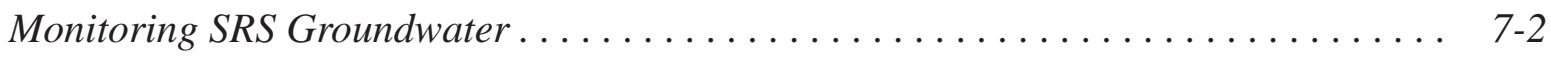

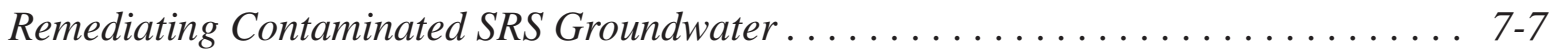

Monitoring Groundwater in Georgia . . . . . . . . . . . . . . . . . 7-7

Using and Conserving SRS Groundwater . . . . . . . . . . . . . . . 7-10

Chapter 8 - Quality Assurance ........................... 8-1

Background ................................ 8-1

Quality Assurance Program Summary . . . . . . . . . . . . . . . . . . 8-1

Environmental Monitoring Progress Assessment Activities . . . . . . . . . . . . . 8-2

Environmental Monitoring Program Quality Control Activities . . . . . . . . . . . . 8-2 
Description

Page

Chapter 9 - Special Studies ......................... 9-1

National Atmospheric Deposition Program . . . . . . . . . . . . . . . . . . 9-1

Comprehensive Survey of Savannah River Creek Plantation Swamp . . . . . . . . . . . . 9-2

American Alligator Public Harvest Program in Georgia and South Carolina . . . . . . 9 9-6

Trophic Modeling to Assess Potential Ecological Threats of Ash Deposits in the Wetlands Area at Dunbarton Bay . . . . . . . . . . . . . . . . . . . . . . . 9-9

Special Study of Mercury and Tin in the Tims Branch Ecosystem . . . . . . . . . . . . 9-11

Appendix A - Radionuclide and Chemical Nomenclature . . . . . . . . . . A-1

Appendix B - Errata $\ldots \ldots \ldots \ldots \ldots \ldots \ldots \ldots \ldots \ldots \ldots \ldots \ldots \ldots \ldots \ldots$ B-1

Glossary .................................. G-1

References .................................... R-1 
This page intentionally left blank. 


\section{LIST OF FIGURES}

Page

Number

Chapter 1 Introduction ......................... 1-1

Figure 1-1 SRS Organization ............................. 1-2

Figure 1-2 The Savannah River Site and Surrounding Area Map ............. 1-5

Chapter 2 Environmental Management System ............... 2-1

Figure 2-1 Environmental Management Systems Integration ................ 2-2

Figure 2-2 DOE-SR Energy Reduction Performance ................. 2-7

Figure 2-3 A-Area Biomass Steam Plant....................... 2-8

Figure 2-4 View of Biomass Cogeneration Facility.................... 2-9

Figure 2-5 SRS Gasoline Reduction Performance .................. 2-11

Figure 2-6 E85 Fuel Usage at SRS ........................ 2-11

Figure 2-7 Mercury Characterization using Traditional Soil Sampling Techniques . 2-14

Figure 2-8 Mercury Characterization using Membrane Interface Probe System . . . 2 2-14

Chapter 3 Compliance Summary ..................... 3-1

Figure 3-1 SRS Workers Pump Grout from a Concrete Mix Truck to Tank 18F . . . . . 3-5

Chapter 4 Effluent Monitoring ....................... 4-1

Figure 4-1 Ten-Year History of SRS Annual Atmospheric Tritium Releases . . . . . . . 4-3

Figure 4-2 Typical SRS Facility Stack. . . . . . . . . . . . . . . . . . 4-4

Figure 4-3 Radiological Surface Water Sampling Locations ................. 4-5

Figure 4-4 Ten-Year History of Direct Release of Tritium to SRS Streams . . . . . . . . 4-6

Figure 4-5 NPDES Industrial Wastewater Outfall Sampling Locations . . . . . . . . . 4-9

Figure 4-6 NPDES Industrial Stormwater Outfall Sampling Locations . . . . . . . . . 4-10

Figure 4-7 $\begin{aligned} & \text { An Automated Water Sampler is Programmed at an Industrial } \\ & \text { Wastewater Outfall . . . . . . . . . . . . . . . . . . . . . . . . . }\end{aligned}$

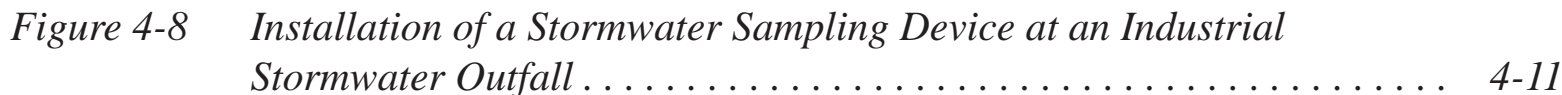


Chapter 5 Environmental Surveillance.................. 5-1

Figure 5-1 SRS Offsite Sampling Media for Georgia and South Carolina ........ . 5-2

Figure 5-2 Environmental Monitoring Field Technician Reads the Flow at the Burial Ground North Air Surveillance Station ............... 5-7

Figure 5-3 An Environmental Monitoring Field Technician Removes TLD from Burial Ground North Air Station . . . . . . . . . . . . . . . . . . 5-9

Figure 5-4 Radiological Surface Water Sampling Locations . ............... . 5-11

Figure 5-5 Maintenance Being Performed on an Automated Sampler at one of the Stream Sampling Locations . . . . . . . . . . . . . . . . . . . . . . . 5-11

Figure 5-6 Ten-Year Trend of Average Tritium Concentration in Locations Pen

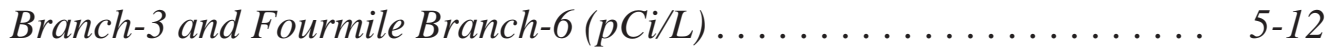

Figure 5-7 Ten-Year Trend of Average Tritium Concentration in Lower Three Runs-3, Steel Creek-4, and Upper Three Runs-4 (pCi/L) . ......... 5-13

Figure 5-8 Estimated Tritium Migration from SRS Seepage Basins and SWDF to

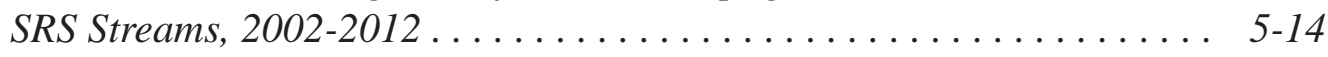

Figure 5-9 Tritium Concentrations in Fourmile Branch, 1997 - 2012 . . . . . . . . 5 5-15

Figure 5-10 Environmental Monitoring Field Technician Performs Area Velocity Measurements across an SRS Stream ................. 5-16

Figure 5-11 Savannah River Surveillance Sample Collection River Mile 160 . . . . . . 5-17

Figure 5-12 SRS Tritium Transport Summary, 1960 - 2012 ................ 5-18

Figure 5-13 Ten-Year Trend of SRS Tritium Transport, 2003 - 2012 ............ 5-19

Figure 5-14 Fish Sample Collection on Savannah River . . . . . . . . . . . . . 5-22

Figure 5-15 Evaluation of Cesium-137 Means (pCi/g) in Bass for the Period 2008

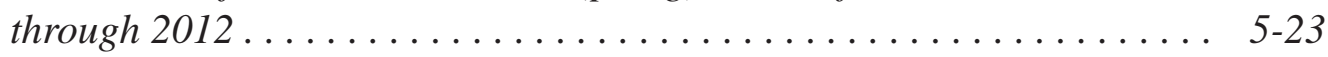

Figure 5-16 Fish Composite Concentrations (at RM-118.8) versus Radioactive Decay for Cesium-137 ........................ 5-23

Figure 5-17 Field Monitoring During the Annual Deer Hunt .............. 5-24

Figure 5-18 Historical Trend of Cesium-137 Concentrations in Deer (pCi/g),

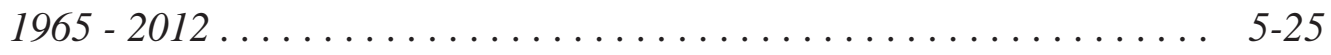

Figure 5-19 Soil Sampling Collection .......................... 5-26

Figure 5-20 Environmental Monitoring Field Technician Collects Grassy Vegetation 5-27

Figure 5-21 Stream Sampling Location .......................... 5 5-29

Figure 5-22 Nonradiological Surface Water Sampling Locations . . . . . . . . . . 5-30

Figure 5-23 Average Mercury Concentrations in Fish by Location and Species for

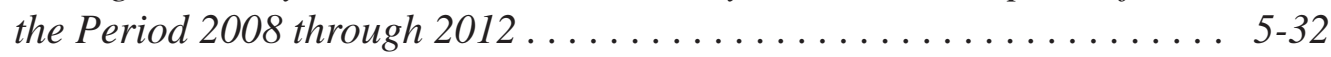




\section{Chapter 6 Radiological Dose Assessments ................... 6-1}

Figure 6-1 Exposure Pathways to Humans from Atmospheric and Liquid Effluents . 6-2

Figure 6-2 Radionuclide Contributions to the 2012 SRS Total Liquid Pathway Dose of 0.23 mrem $(0.0023 \mathrm{mSv}) \ldots \ldots \ldots \ldots \ldots \ldots \ldots \ldots \ldots \ldots . \ldots \ldots$

Figure 6-3 Radionuclide Contributions to the 2012 SRS Pathway Dose of 0.027

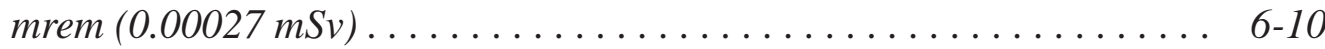

Figure 6-4 Ten-Year History of SRS Maximum Potential All-Pathway Doses . . . . . . 6-12

Figure 6-5 Ten-Year History of SRS Creek-Mouth Fisherman's Doses . . . . . . . . . . 6-15

Chapter 7 Groundwater.......................... 7-1

Figure $7-1 \quad$ Groundwater Plumes at SRS ....................... $7-3$

Figure 7-2 Location of Site Boundary Wells at SRS - Between A/M Areas and Jackson, South Carolina (Nearest Population Center) . . . . . . . . . 7-5

Figure 7-3 Location of Tritium Wells Sampled in Burke and Screven Counties, Georgia .............................. $7-8$

Figure 7-4 Time-Trend Data for Georgia Tritium Wells.................. 7-9

Chapter 8 Quality Assurance ........................ 8-1

Figure 8-1 Field Technician Preparing to Deploy RiverSurveyor ${ }^{\circledR}$ in SRS Waterway 8-2

Figure 8-2 Fish Samples Being Prepared in an SRS Laboratory ............. 8-3 


\section{Chapter 9}

Figure 9-1
Special Studies

2011 Total Mercury in Rainfall Results from the National Atmospheric Deposition Program (NADP) . . . . . . . . . . . . . . . .
9-1

Figure 9-2 2012 Results from Cesium-137 in Surface Soil at Creek Plantation and 2011 Aerial Gamma Survey Measurements . . . . . . . . . . . . . . . . . . 9-4

Figure 9-3 Mature American Alligators Basking in the Sun on the Banks of L-Lake. 9-6

Figure 9-4 American Alligator Harvest Data for Counties that Border SRS (Data Compiled from South Carolina Department of Natural Resources Reports) .

Figure 9-5 Comparison of Mercury and Radionuclides observed in American Alligator with Range Observed in Edible Fish. . . . . . . . . . . . . . . 9-9

Figure 9-6 Centipede Collected at the Wetland Area at Dunbarton Bay . . . . . . . . 9-10

Figure 9-7 Three Species of the Genus Rana (True Frogs) Collected from the WADB Sampling Effort: Green Frog, Bullfrog, and Leopard Frog . . . . 9 9-10

Figure 9-8 Photo of Raccoon (Procyon lotor) at SRS . . . . . . . . . . . . . 9-11

Figure 9-9 Photo of a Great Blue Heron (Ardea herodia) at SRS . . . . . . . . . . . . . 9-11

Figure 9-10 SRS Modified the M1 Air Stripper System in 2007 to Remove Mercury . . 9-11

Figure 9-11 SRNL Scientist Collects Water Samples from Tims Branch . . . . . . . . . . 9-12

Figure 9-12 Florida International University Student Marks a Sampling Location along Tims Branch . . . . . . . . . . . . . . . . . . . . . 9 9-12

Figure 9-13 Oak Ridge Scientists Collect Fish Samples in 2011 to Support Research on the Impacts of the Mercury Treatment in Tims Branch . . . . . . . . . . 9-12 


\section{LIST OF TABLES}

Page

Number

Chapter 2 Environmental Management System ............... 2-1

Table 2-1 2012 SRS EMS Targets (Summary) ....................... 2-3

Table 2-2 2012 SRS Pollution Prevention Activities .................. 2-6

Chapter 3 Compliance Summary ...................... 3-1

Table 3-1 Key Federal Environmental Laws and Regulations Applicable to SRS . . . . 3-2

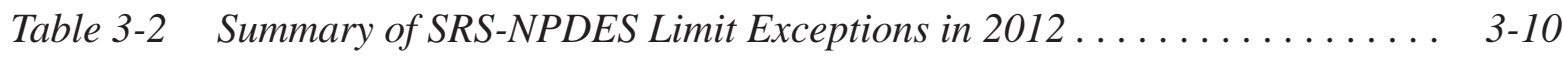

Table 3-3 Summary of SRS-Related NEPA Reviews in $2012 \ldots \ldots \ldots \ldots \ldots \ldots$. . . . . . . . . . .

Table 3-4 SRS NOV/NOAV Summary, 2008 - $2012 \ldots \ldots \ldots \ldots \ldots \ldots \ldots \ldots$. . . . . . . . . . . .

Table 3-5 2012 SRS Self-Assessment Summaries . . . . . . . . . . . . . . . . . . . 3-17

Table 3-6 2012 External Audits/Inspections and Results . . . . . . . . . . . . . . . 3-19

Table 3-7 SRS Construction and Operating Permits, $2012 \ldots \ldots \ldots \ldots \ldots \ldots$. $3-22$

Chapter 4 Effluent Monitoring $\ldots \ldots \ldots \ldots \ldots \ldots \ldots \ldots \ldots \ldots \ldots$ 4-1

Table 4-1 SRS Estimated SCDHEC Standard 2 Pollutant Air Emissions, 2008 - 2012 (TV-0080-0041 \& TV-0300-00036) . . . . . . . . . . . . . . . . . 4-8

Chapter 5 Environmental Surveillance ..................... 5-1

Table 5-1 Offsite Radiological Annual Sampling Collection and Monitoring Distribution by State . . . . . . . . . . . . . . . . . . . . . . . . 5-3

Table 5-2 Radiological Surveillance Sampling Frequencies .............. 5-4

Table 5-3 Atmospheric Surveillance Stations ....................... 5-5

Table 5-4 2012 Average Tritium-in-Air Results $\left(p C i / m^{3}\right), 2008$ - $2012 \ldots \ldots \ldots \ldots$. . . . .

Table 5-5 2012 Tritium-in-Rainwater Results $(p C i / L) \ldots \ldots \ldots \ldots \ldots \ldots \ldots$ 5-8

Table 5-6 Average Gross Alpha, Gross Beta, and Tritium Summary for Stormwater Basins .................................... 5-10

Table 5-7 Radionuclides in Z-Area Basin . . . . . . . . . . . . . . . . . . 5 5-10

Table 5-8 2012 Concentrations of Radioactivity in SRS Stream Locations Prior to Entry into the Savannah River ...................... 5-12

Table 5-9 Tritium Migration Total (Curies) From SRS Seepage Basins and SWDF . . 5-14 Table 5-10 Migration into Fourmile Branch - Estimates, Total (Curies) . . . . . . . . 5-15 Table 5-11 Average 2012 Concentrations of Radioactivity in the Savannah River . . . 5-17 
Page

Number

Table 5-12 Radionuclides Detected in Food Products in 2012 . . . . . . . . . . . . . . 5-21

Table 5-13 Radionuclides Detected in Milk Products in 2012 . . . . . . . . . . . . . . 5-21

Table 5-14 2012 Cesium-137 Results for Laboratory and Field Measurements . . . . . 5-24

Table 5-15 Nonradiological Sampling Frequencies . . . . . . . . . . . . . . . . . 5-28

Table 5-16 South Carolina Water Quality Standards for Freshwaters . . . . . . . . . . 5-29

Chapter 6 Radiological Dose Assessments .................. 6-1

Table 6-1 Comparison of Reference and Typical Person Usage Parameters with Pre-2012 Usage Parameters . . . . . . . . . . . . . . . . . . . . . . . 6 6-3

Table 6-2 2012 Radioactive Liquid Release Source Term and 12-Month Average Downriver Radionuclide Concentrations Compared to the EPA's Drinking Water Maximum Contaminant Levels (MCL) . . . . . . . . . . . . 6-6

Table 6-3 Potential Dose to the Maximally Exposed Individual from SRS Liquid Releases in $2012 \ldots \ldots \ldots \ldots \ldots$. . . . . . . . . . . . . 6-7

Table 6-4 Potential Doses to the Representative Person and to the MEI from SRS Atmospheric Releases in 2012 and Comparison to the Applicable Dose Standard ............................. 6-9

Table 6-5 2012 Representative Person All-Pathways and Sportsman Doses Compared to the DOE All-Pathways Dose Standard . . . . . . . . . . . . 6-13

Table 6-6 Potential Lifetime Risks from the Consumption of Savannah River Fish Compared to Dose Standards . . . . . . . . . . . . . . . . . 6-16

Chapter 7 Groundwater.......................... 7-1

Table 7-1 Summary of Maximum Well Monitoring Results for Major Areas within SRS (2012) . . . . . . . . . . . . . . . . . . . . . . 7-6

Chapter 9 Special Studies . . . . . . . . . . . . . . . . . . . . . 9-1

Table 9-1 2012 TLD Survey Results for Creek Plantation, millirem . . . . . . . . . . . 9 9-3

Table 9-2 Results for Cesium-137 in Soil and Vegetation at Creek Plantation, pCi/g . 9-5

Table 9-3 Cesium-137 and Strontium-89, 90 Results for Timber Wood Chips near Creek Plantation Trail 1 . . . . . . . . . . . . . . . . . . . 9 9-5

Table 9-4 Total Mercury and Radionuclides from American Alligators harvested from the Savannah River near Little Hell Landing (River Mile 135) . . . . 9-8 


\section{ACRONYMS AND ABBREVIATIONS}

Note: sampling location abbreviations can be found on page xxv

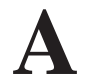

ACM

ADN

AEA

AERMOD

AFS

AFV

ALARA

ANS

ARP

ATSDR

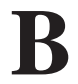

BAT

BCF

BCG

BGN

BJWSA

BTU/GSF

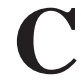

C\&D

CAA

CAAA

CAB

CD

CEI

CERCLA

CFR

$\mathrm{Ci}$

CMC

CO

COE

COR
Asbestos-Containing Material

Asbestos Disturbance Notice

Atomic Energy Act of 1954

American Meteorological Society/Environmental Protection Agency Regulatory Model

Alternative Feed Stock

Alternative Fuel Vehicles

As Low As Reasonably Achievable

Academy of Natural Sciences

Actinide Removal Process

Agency for Toxic Substances and Disease Registry

Best Available Technology

Biomass Cogeneration Facility

Biota Concentration Guide

Burial Ground North

Beaufort-Jasper Water and Sewer Authority

British Thermal Units per Gross Square Foot

Construction and Demolition

Clean Air Act

Clean Air Act Amendments

Citizens Advisory Board

Compact Disk

Compliance Evaluation Inspection

Comprehensive Environmental Response, Compensation, and Liability Act

Code of Federal Regulations

Curie

Chemical Management Center

Carbon monoxide

Corps of Engineers

Challenges, Opportunities, and Resolution 


$\begin{array}{ll}\text { CPT } & \text { Cone Penetrometer Technology } \\ \text { CR } & \text { Control Room } \\ \text { CRMP } & \text { Cultural Resources Management Plan } \\ \text { CSRA } & \text { Central Savannah River Area } \\ \text { CWA } & \text { Clean Water Act } \\ \text { CX } & \text { Categorical Exclusion } \\ \text { CY } & \text { Calendar Year } \\ & \\ \text { D } & \\ \text { DCS } & \text { Derived Concentration Standard } \\ \text { DEAR } & \text { Department of Energy Acquisition Regulations } \\ \text { DNR } & \text { Department of Natural Resources } \\ \text { DOD } & \text { U.S. Department of Defense } \\ \text { DOE } & \text { U.S. Department of Energy } \\ \text { DOE-SR } & \text { U.S. Department of Energy - Savannah River } \\ \text { DOECAP } & \text { DOE Consolidated Audit Program } \\ \text { DUS } & \text { Dynamic Underground Stripping } \\ \text { DWPF } & \text { Defense Waste Processing Facility } \\ \text { DWS } & \text { Drinking Water Standards }\end{array}$

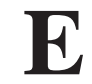

EA

EC\&ACP Environmental Compliance and Area Completion Projects

EDAM Environmental Dose Assessment Manual

EDP Economic Development Partnership

EEC Environmental Evaluation Checklist

EIS

EISA Energy Independence and Security Act

EM Environmental Management

EML Environmental Monitoring Laboratory

EMS Environmental Management System

EO Executive Order

EPA U.S. Environmental Protection Agency

EPCRA Emergency Planning and Community Right-to-Know Act

EPEAT Electronic Product Environmental Assessment Tool

EPP Environmentally Preferable Purchasing

eQUEST The Quick Energy Simulation Tool

EQMD Environmental Quality Management Division

ESA Endangered Species Act

ESEC Environmental Science Education Cooperative

ESPC Energy Savings Performance Contract 


\section{$\mathbf{F}$}

FEIS

FFA

FFCA

FFCACt

FIFRA

FIMS

FMP

FONSI

ft

$\mathbf{f t}^{2}$

$\mathrm{ft}^{3}$

FTF

FY

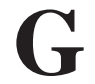

GDNR

GHG

GSA

GPS

GTCC LLW
Final Environmental Impact Statement

Federal Facility Agreement

Federal Facility Compliance Agreement

Federal Facility Compliance Act

Federal Insecticide, Fungicide, and Rodenticide Act

Flow Injection Mercury Systems

Fish Monitoring Plan

Finding of No Significant Impact

Feet/Foot

Square Feet

Cubic Feet

F-Tank Farm

Fiscal Year

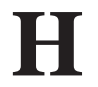

HANM

HFC

HPSB

HQ

HSWA

HVAC

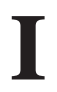

I\&D

IAPCR

ICP-AES

ICP-MS

ICRP

ISMS

ISO
Georgia Department of Natural Resources

Greenhouse Gases

General Separations Area

Global Positioning System

Greater-Than-Class-C Low-Level Radioactive Waste

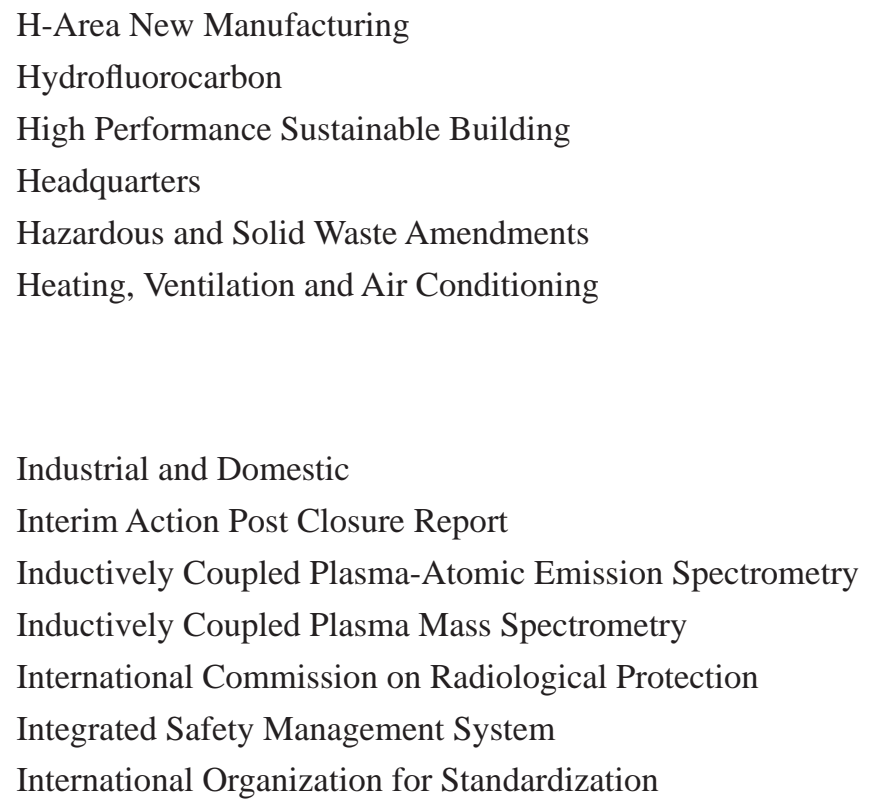




\section{K}

Kg

L

lb

LDR

LEED $^{\circledR}$

LOAEL

LWO

M

M\&O

MACT

MAPEP

MBTA

MCL

MDC

MDL

MDN

MSDU

MEI

MFFF

mi

$\mathbf{m i}^{2}$

MOX

mrem

MRF

mSv

MT

MW

MWMF

$\mathbf{N}$

NADP

NBN

NDAA

NEPA

NESHAP

NHPA

NNSA

NOAV

NOV
Kilogram

Pound

Land Disposal Restrictions

Leadership in Energy and Environmental Design

Lowest Observable Adverse Effect Level

Liquid Waste Operations

Management and Operating

Maximum Achievable Control Technology

Mixed Analyte Performance Evaluation Program

Migratory Bird Treaty Act of 1918

Maximum Contaminant Levels

Minimum Detectable Concentration

Method Detection Limit

Mercury Deposition Network

Mega Saltstone Disposal Unit

Maximally Exposed Individual

Mixed Oxide Fuel Fabrication Facility

Mile

Square Mile

Mixed Oxide

Millirem

Material Recovery Facility

Millisievert

Metric Ton

Mixed Waste

Mixed Waste Management Facility

National Atmospheric Deposition Program

No Building Number

National Defense Authorization Act

National Environmental Policy Act

National Emission Standards for Hazardous Air Pollutants

National Historic Preservation Act

National Nuclear Security Administration

Notices of Alleged Violation

Notice of Violation 


\begin{tabular}{|c|c|}
\hline NOx & Oxides of Nitrogen \\
\hline NPDES & National Pollutant Discharge Elimination System \\
\hline NPL & National Priority List \\
\hline NRC & Nuclear Regulatory Commission \\
\hline NRHP & National Register of Historic Places \\
\hline NTN & National Trends Network \\
\hline NWPs & Nationwide Permits \\
\hline O\&M & Operations and Maintenance \\
\hline ODS & Ozone-Depleting Substances \\
\hline ORNL & Oak Ridge National Laboratory \\
\hline ORPS & Occurrence Reporting and Processing System \\
\hline OSHA & Occupational Safety and Health Administration \\
\hline $\mathbf{P} 2$ & Pollution Prevention \\
\hline PA & Performance Assessments \\
\hline PC & Personal Computers \\
\hline PCB & Polychlorinated biphenyl \\
\hline PCE & Tetrachloroethylene \\
\hline $\mathrm{pCi} / \mathrm{g}$ & Picocuries per gram \\
\hline $\mathbf{p C i} / \mathbf{L}$ & Picocuries per liter \\
\hline PGP & General Permit for Discharges of Application of Pesticide \\
\hline $\mathbf{p H}$ & $\begin{array}{l}\text { Measure of the hydrogen ion concentration in an aqueous solution (acidic solutions, } \mathrm{pH} \\
\text { from } 0 \text { to } 6 \text {; basic solutions, } \mathrm{pH}>7 \text {; and neutral solutions, } \mathrm{pH}=7 \text { ) }\end{array}$ \\
\hline $\mathbf{P M}$ & Particulate Matter \\
\hline ppm & Parts Per Million \\
\hline PQL & Practical Quantification Limit \\
\hline PUE & Power Usage Effectiveness \\
\hline QA & Quality Assurance \\
\hline QC & Quality Control \\
\hline RCRA & Resource Conservation and Recovery Act \\
\hline RHA & Rivers and Harbors Act \\
\hline $\mathbf{R M}$ & River Mile \\
\hline RMP & Risk Management Program \\
\hline
\end{tabular}




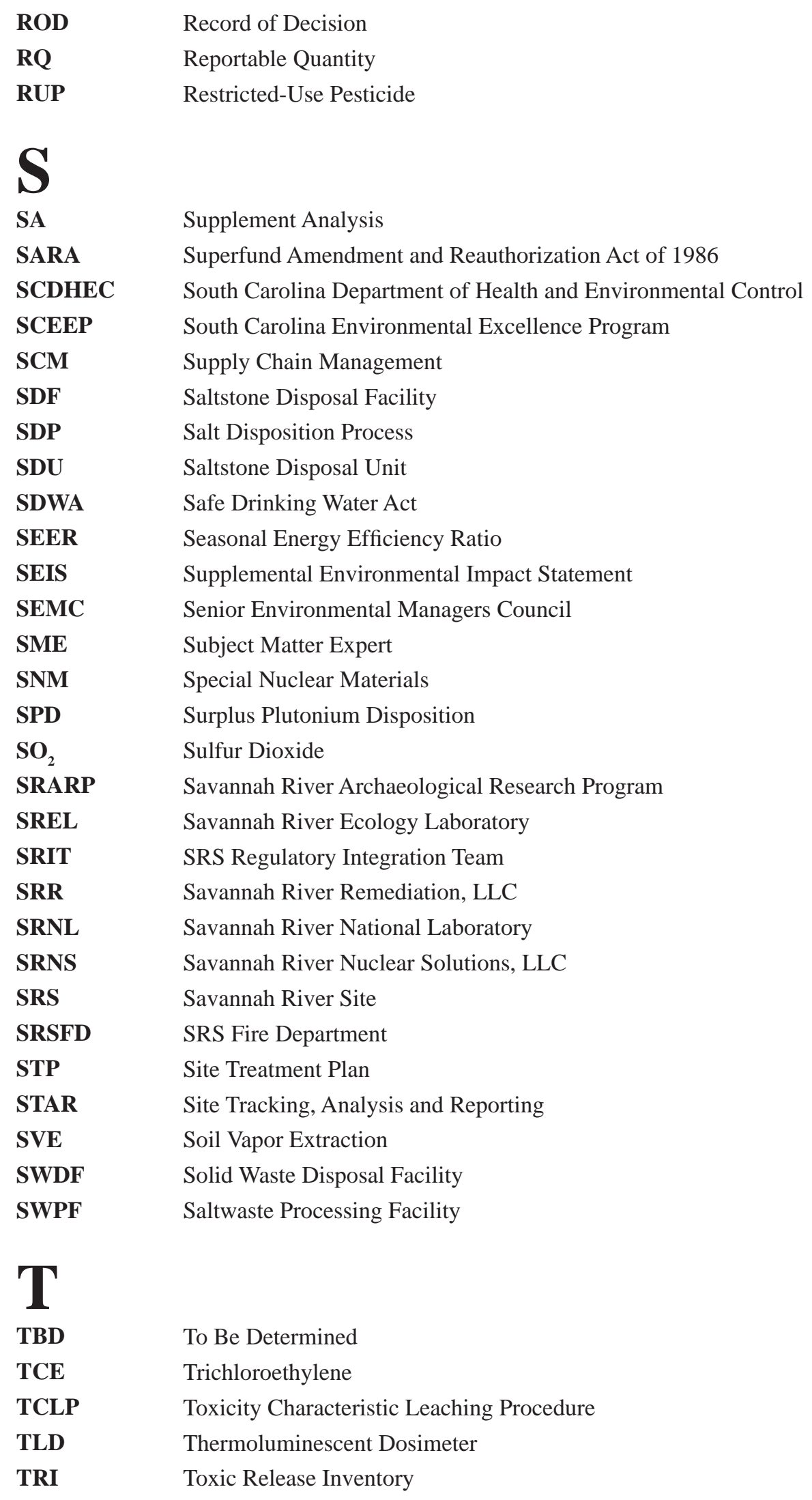


TRU Transuranic

TSCA Toxic Substances Control Act

TSS Total Suspended Solids

TVA Tennessee Valley Authority

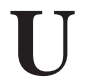

USDA U.S. Department of Agriculture

USFS-SR U.S. Forest Service-Savannah River

USGS U.S. Geological Survey

UST Underground Storage Tanks

VEGP Vogtle Electric Generating Plant

VOC Volatile Organic Compound

W

WADB Wetland Area at Dunbarton Bay

WQC Water Quality Criteria

WIPP Waste Isolation Pilot Plant

WSB Waste Solidification Building

WSI Wackenhut Services, Inc.

WSTS Western Sector Treatment System 
This page intentionally left blank. 


\section{SAMPLING LOCATION INFORMATION}

Note: $\quad$ This section contains sampling location abbreviations used in the text and/or on the sampling location maps. It also contains a list of sampling locations known by more than one name (see next page).

\begin{tabular}{|l|l|}
\hline Location Abbreviations & Location Name/Other Applicable Information \\
\hline 4M & Fourmile \\
\hline 4MB & Fourmile Branch (Fourmile Creek) \\
\hline 4MC & Fourmile Creek \\
\hline BDC & Beaver Dam Creek \\
\hline BG & Burial Ground \\
\hline EAV & E-Area Vaults \\
\hline FM & Four Mile \\
\hline FMB & Fourmile Branch (Fourmile Creek) \\
\hline GAP & Georgia Power Company \\
\hline HP & HP (sampling location designation only; not an actual abbreviation) \\
\hline HWY & Highway \\
\hline KP & Kennedy Pond \\
\hline L3R & Lower Three Runs \\
\hline NRC & Nuclear Regulatory Commission \\
\hline NSB L\&D & New Savannah Bluff Lock \& Dam (Augusta Lock and Dam) \\
\hline PAR & "P” and “R” Pond \\
\hline PB & Pen Branch \\
\hline RM & River Mile \\
\hline SC & Steel Creek \\
\hline SWDF & Solid Waste Disposal Facility \\
\hline TB & Tims Branch \\
\hline TC & Tinker Creek \\
\hline TNX & Multipurpose Pilot Plant Campus \\
\hline U3R & Upper Three Runs \\
\hline VEGP & Vogtle Electric Generating Plan (Plant Vogtle) \\
\hline & \\
\hline
\end{tabular}




\begin{tabular}{|l|}
\hline Sampling Locations Known by More Than One Name \\
\hline Augusta Lock and Dam; New Savannah River Lock \& Dam \\
\hline Beaver Dam Creek; 400-D \\
\hline Fourmile Creek-2B; Fourmile Creek at Road C \\
\hline Fourmile Creek-3A; Fourmile Creek at Road C \\
\hline Lower Three Runs-2; Lower Three Runs at Patterson Mill Road \\
\hline Lower Three Runs-3; Lower Three Runs at Highway 125 \\
\hline Pen Branch-3; Pen Branch at Road A-13-2 \\
\hline R-Area downstream of R-1; 100-R \\
\hline River Mile 118.8; U.S. Highway 301 Bridge Area; Highway 301, US 301 \\
\hline River Mile 129.1; Lower Three Runs Mouth \\
\hline River Mile 141.5; Steel Creek Boat Ramp \\
\hline River Mile 150.4; Vogtle Discharge \\
\hline River Mile 152.1; Beaver Dam Creek Mouth \\
\hline River Mile 157.2; Upper Three Runs Mouth \\
\hline River Mile 160.0; Dernier Landing \\
\hline Steel Creek at Road A; Steel Creek-4; Steel Creek-4 at Road A; Steel Creek at Highway 125 \\
\hline Tims Branch at Road C; Tims Branch-5 \\
\hline Tinker Creek at Kennedy Pond; Tinker Creek-1 \\
\hline Upper Three Runs-4; Upper Three Runs-4 at Road A; Upper Three Runs at Road A; Upper Three Runs at \\
Hwy 125 \\
\hline Upper Three Runs-1A; Upper Three Runs-1A at Road 8-1 \\
\hline Upper Three Runs-3; Upper Three Runs-3 at Road C \\
\hline Highway 17 Bridge; Houlihan Bridge \\
\hline Stokes Bluff; Stokes Bluff Landing \\
\hline
\end{tabular}




\section{INTRODUCTION}

Michael Griffith

Environmental Compliance \& Area Completion Projects

Timothy Jannik

Savannah River National Laboratory

This report was prepared in accordance with United States Department of Energy (DOE) Order 231.1B "Environ-

1 mental, Safety, and Health Reporting” to present summary environmental data for the Savannah River Site (SRS)

for the purpose of:

- highlighting significant Site programs and efforts,

- summarizing environmental occurrences and responses reported during the calendar year,

- describing compliance status with respect to environmental standards and requirements,

- characterizing the Site's environmental management performance, and

- $\quad$ providing results for radiological monitoring and clearance of property.

This report is the principal document that demonstrates compliance with the requirements of DOE Order 458.1, "Radiation Protection of the Public and the Environment," and is a key component to DOE's effort to keep the public informed of environmental conditions at SRS.

\section{Missions}

The mission of SRS is to safely and efficiently operate SRS to protect the public health and the environment while supporting the nation's nuclear deterrent and the transformation of the Site for future use. Activities at SRS are organized around three primary mission areas to support the DOE Environmental Management (EM) program, the National Nuclear Security Administration (NNSA), and the needs of the nation:

- Environmental Stewardship - Focused on reducing the environmental legacy of nuclear materials and radioactive waste at SRS through initiatives such as groundwater restoration, deactivation and decommissioning of excess contaminated facilities, and radioactive waste disposition.

- National Security - Focused on enhancing national security through innovative solutions to safely manage nuclear materials, including the disposition of surplus nuclear materials, tritium supply, and nuclear stockpile maintenance and evaluation.

- Clean Energy - Focused on research and development to accelerate technology development through public and private partnerships to sustainably provide regional energy while protecting environmental health.

In 2012, SRS continued implementation of the Enterprise•SRS initiative to develop broader missions for SRS to serve national needs in the primary mission areas. More information can be obtained by viewing SRS's website at http://www.srs.gov/general/srs-home.html. 


\section{Organization}

To execute SRS's missions, the DOE uses a number of contractors in various supporting roles. The relationship of these contractors with DOE is shown in Figure 1-1 and each entity is described below.

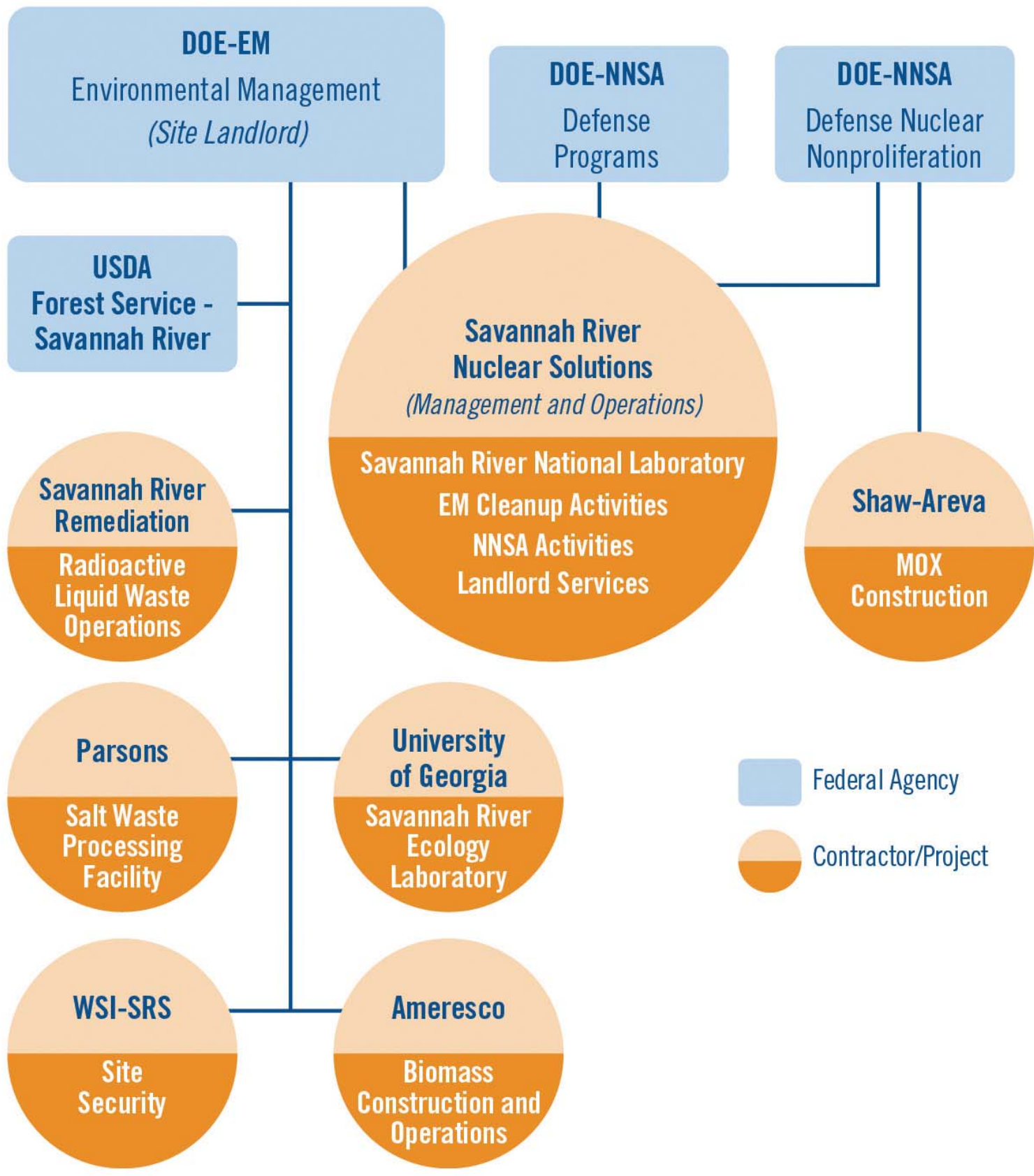

Figure 1-1 SRS Organization 
The DOE Savannah River Operations Office (DOE-SR) is responsible for oversight of Environmental Management operations and landlord services at SRS. More information can be obtained by viewing the DOE-SR website at http://sro.srs.gov.

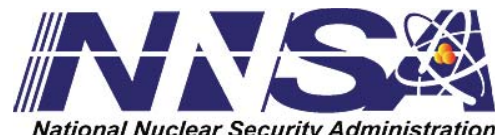

Three NNSA offices, the Savannah River Field Office (NNSA-SRFO), the Office of Fissile Materials Disposition (NA-26), and the Office of Acquisition and Project Management (NA-APM) oversee the NNSA missions and project at SRS. These organizations are responsible for management of key program areas including Defense Programs, Nuclear Nonproliferation, National Security, emergency operations related to SRS tritium facility operations and DOE/ NNSA Radiological Emergency Response assets.

Savannah River Nuclear Solutions, LLC (SRNS), a joint venture of Fluor Corporation, Newport News Nuclear, and Honeywell International, Inc., is the SRS management and operations (M\&O) contractor. SRNS operates the Savannah River National Laboratory (SRNL), nuclear materials and used nuclear fuel facilities, solid waste management facilities, tritium programs, Site infrastructure, and waste site remediation and closure projects. More information can be obtained by viewing the SRNS website at http://www.savannahrivernuclearsolutions.com.

Operated by SRNS, SRNL is SRS's and DOE-EM's applied research and development laboratory. SRNL creates and implements practical, high-value, cost-effective technology solutions in the areas of environmental stewardship, national security, and clean energy. SRNL also provides technical leadership and key support for future SRS missions. More information can be obtained by viewing SRNL's website at http://srnl.doe.gov.

Savannah River Remediation LLC (SRR) is the liquid waste contractor for DOE-SR. SRR treats, stores, and disposes of radioactive liquid waste. SRR is composed of a team of companies led by URS Corporation with partners Bechtel National, CH2M Hill, and Babcock \& Wilcox. Critical subcontractors for the contract are AREVA, Energy Solutions, and URS Safety Management Solutions. More information can be obtained by viewing the SRR website at http://srremediation.com.

Parsons Government Services, Inc. is under contract with DOE-SR to design, build, startup, and operate the Salt Waste Processing Facility. More information can be obtained by viewing the Parsons website at http://www.parsons.com/projects/Pages/salt-waste-processing-facility.aspx.

Shaw Areva MOX Services, LLC is under contract with NNSA and is responsible for the design, construction, startup, and operation of the SRS Mixed Oxide (MOX) Fuel Fabrication Facility. More information can be obtained by viewing the Shaw Areva MOX Services website at http://www.moxproject.com.

Ameresco Federal Solutions, Inc. constructed and now operates biomass steam generating plants in $\mathrm{K}$ and $\mathrm{L}$ Areas and the steam and electricity cogeneration plant near F Area. DOE has contracted Ameresco to supply steam and electricity to SRS. The biomass steam generating and steam and electricity cogeneration plants data is not included in the Annual Environmental Report because the facilities operate under environmental permits issued directly to Amersco by SCDHEC. More information can be obtained by viewing the Ameresco website at http://www.ameresco.com/sites/default/files/cs savriver v5.pdf. 


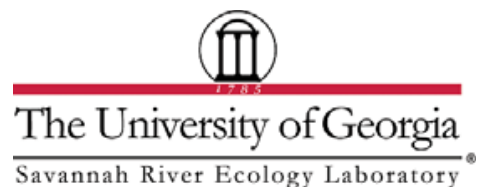

U.S. Department of Agriculture
Forest Service
Southern Region
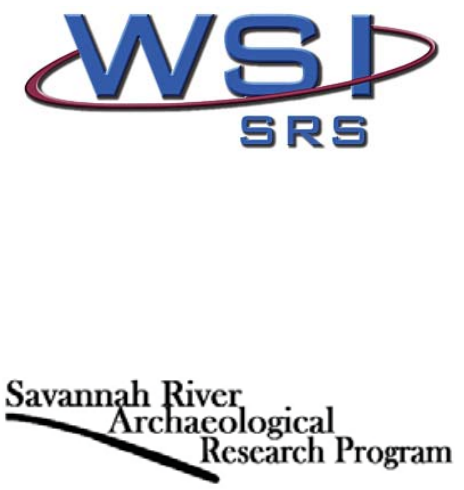

The Savannah River Ecology Laboratory (SREL) is a research unit of the University of Georgia that has been conducting ecological research at SRS for more than 60 years. The facility's overall mission is to acquire and communicate knowledge of ecological processes and principles. SREL conducts fundamental and applied ecological research, as well as education and outreach programs under a cooperative agreement with DOE-SR. More information can be obtained by viewing the laboratory's website at http://www.srel.edu.

Under an Interagency Agreement with DOE-SR, the United States Department of Agriculture (USDA) Forest Service-Savannah River (USFS-SR) contributes to environmental stewardship at SRS by: managing the Site's natural resources, including timber; maintaining and improving habitat for threatened, endangered, and sensitive species; maintaining secondary roads and site boundaries; performing prescribed burns and protecting the site from wild-land fires; and evaluating the effects of its management practices on the environment. More information can be obtained by viewing the USFS-SR website at http://www.fs.usda.gov/savannahriver.

Wackenhut Services, Inc. (WSI-SRS) is contracted by DOE-SR to provide a protective force that fulfills security requirements and executes emergency contingency plans that protect special nuclear materials, government assets, site employees, and surrounding communities from security threats. More information can be obtained by viewing the corporate website at http://www.g4sgs.com/.

The Savannah River Archaeological Research Program (SRARP) is a research unit of The University of South Carolina that provides the technical expertise to support DOE management of SRS cultural resources. SRARP responsibilities include identifying, evaluating, and protecting SRS archaeological sites and artifacts, conducting compliance based research, offering public outreach programs, and preparing documents and reports for state and Federal regulators. More information can be obtained by viewing the SRARP website at http://www.srarp.org.

\section{Site Location, Demographics, and Environment}

SRS was constructed during the early 1950s to produce materials (primarily plutonium-239 and tritium) used in nuclear weapons. The Site, which borders the Savannah River, covers about 310 square miles in the South Carolina counties of Aiken, Allendale, and Barnwell. SRS is about 12 miles south of Aiken, South Carolina, and 15 miles southeast of Augusta, Georgia (Figure 1-2). The Savannah River flows along a portion of the Site's southwestern border. The capital letters within the SRS borders on Figure 1-2 identify operations areas referenced throughout this report.

Based on the U.S. Census Bureau's 2010 decennial data, the population within a 50-mile radius of the center of SRS is about 781,060. This translates to an average population density of about 104 people per square mile outside the SRS boundary, with the largest concentration in the Augusta metropolitan area. 


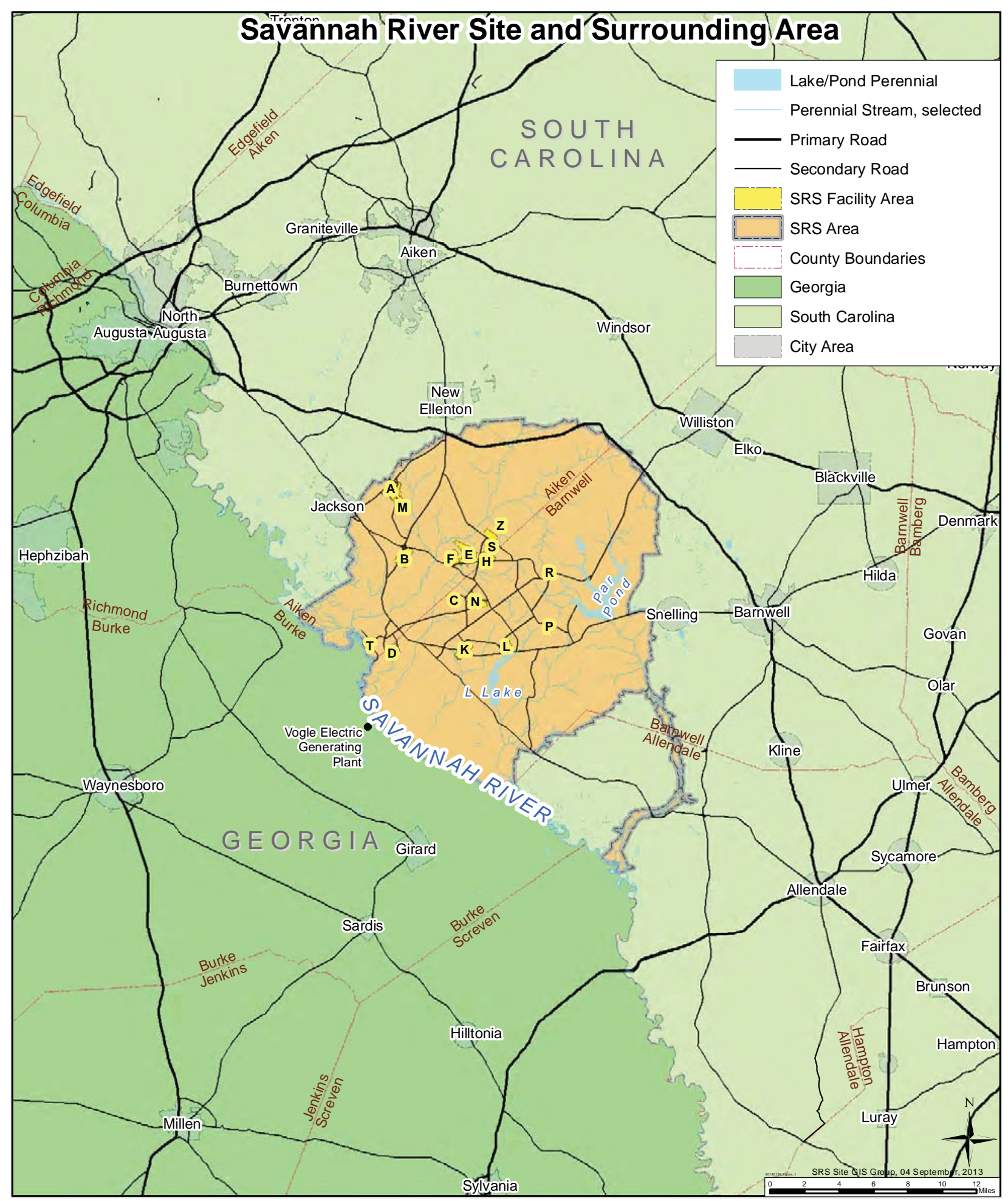

Figure 1-2 The Savannah River Site and Surrounding Area 


\section{Water Resources}

SRS is bounded on the southwest by the Savannah River for about 35 river miles and is about 160 river miles from the Atlantic Ocean. The nearest downriver municipal facility that uses the river as a drinking water source (BeaufortJasper Water and Sewer Authority's Purrysburg Water Treatment Plant) is about 90 river miles from the site. The river also is used for commercial and sport fishing, boating, and other recreational activities. No known large-scale uses of the river exist for irrigation by farming operations downriver of the Site.

The groundwater flow system at SRS consists of four major aquifers. Groundwater generally migrates downward as well as laterally, eventually either discharging into the Savannah River and its tributaries or migrating into the deeper regional flow system. SRS groundwater is used on Site both for industrial processes and drinking water.

\section{Geology}

SRS is on the southeastern Atlantic Coastal Plain, part of the larger Atlantic Plain that extends south from New Jersey to Florida. The center of SRS is about 25 miles southeast of the geological fall line that separates the Coastal Plain from the Piedmont. The catastrophic Charleston Earthquake of 1886 dominates characterization of regional earthquake activity (estimated magnitude of 7.0 on the Richter scale). With nearly three centuries of available historic and contemporary seismic data, the Charleston/Summerville area remains the most seismically active region of South Carolina and the most significant seismogenic region affecting SRS. Ongoing studies by University of South Carolina seismologists suggest a recurrence interval of 500 - 600 years for magnitude 7.0 or greater earthquakes (similar to the 1886 event) near Charleston (Taiwani 2001). Levels of seismic activity within this region are very low, with magnitudes or sizes generally less than or equal to 3.0.

\section{Land and Forest Resources}

About 90 percent of SRS land area consists of natural and managed forests planted, maintained, and harvested by the USFS-SR. The Site contains four major forest types: mixed pine-hardwoods, sandhills pine savanna, bottomland hardwoods, and swamp floodplain forests. More than 345 Carolina bays exist on SRS. Carolina bays are relatively shallow depressions that provide important wetland habitat and refuge for many plants and animals.

\section{Animal and Plant Life}

The majority of SRS is undeveloped; only about 10 percent of the total land area is developed or used for missionorientated facilities. The remainder is maintained in healthy, diverse ecosystems. SRS is home to about 1,500 species of plants, more than 100 species of reptiles and amphibians, some 50 species of mammals, nearly 100 species of fish, and provides habitat for more than 250 species of birds. Nearly 600 species of aquatic insects can be found in SRS streams and wetlands. The Site also provides habitat for a number of protected species including the wood stork, the red-cockaded woodpecker, the pondberry, and the smooth purple coneflower (all federally listed as endangered) and at least 40 plant species of state or regional concern.

\section{DOE EM Primary Site Activities}

\section{Nuclear Materials Stabilization}

In the past, the separations facilities located in the core area of the SRS processed special nuclear materials (SNM) and used fuel from Site reactors to produce materials for nuclear weapons and isotopes for medical and National Aeronautics and Space Administration (NASA) applications. The end of the Cold War in 1991 brought a shift in the mission of these facilities to stabilization of nuclear materials from onsite and offsite sources for safe storage or disposition. 
SRS's two primary separations facilities, called "canyons” because of their resemblance to a gorge in a deep valley between steeply vertical cliffs, are located in F and H Areas. The canyon buildings are 835 feet long, 122 feet wide and 66 feet tall, with several levels to accommodate the various stages of material stabilization, including control rooms to monitor overall equipment and operating processes, equipment and piping gallery for solution transport, storage, and disposition, and unique overhead bridge cranes to support overall process operations. F Canyon and $\mathrm{H}$ Canyon are where nuclear materials were chemically recovered and purified. F Canyon was deactivated in 2006 while H Canyon continues to operate.

An important part of H Canyon's mission is the conversion of weapons-usable, highly enriched uranium to lowenriched uranium. The uranium is then used in the manufacturing of commercial reactor fuel, which is a key function of the nation's nuclear nonproliferation program. With the implementation of Enterprise•SRS, H Canyon was selected to support several potential mission initiatives. While many of the new campaigns are in the planning phase, $\mathrm{H}$ Canyon has begun dissolving and purifying a quantity of SRS excess plutonium to provide the initial feed material to the MOX Fuel Fabrication Facility (MFFF). H Canyon is also dissolving and disposing of vulnerable sodium experimental reactor fuel while also conducting tests to support NNSA's Next Generation Safeguards Initiative. During 2012, SRS continued to use $\mathrm{H}$ Canyon and HB Line to prepare surplus plutonium materials for disposition at the Waste Isolation Pilot Plant (WIPP) in New Mexico. More information can be obtained by viewing SRS's website at

http://www.srs.gov/general/programs/harea/index.htm.

\section{Nuclear Materials Consolidation and Storage}

SRS provides for the handling and interim storage of our nation's excess plutonium and other SNM and fulfills the United States' commitment to international nonproliferation efforts in a safer and environmentally sound manner. The K-Area Complex is DOE's only SNM storage facility designated for interim safe storage of plutonium. The principal operations building formerly housed K Reactor, which produced nuclear materials to support the United States during the Cold War for nearly four decades. DOE has revitalized this very robust structure to safely store nuclear materials. More information can be obtained by viewing the Nuclear Materials Management page on SRS's website at http://www.srs.gov/general/programs/nmm/index.htm.

\section{Used Nuclear Fuel Storage}

The mission of the Used Nuclear Fuel (UNF) program is to support the Global Threat Reduction Initiative and research reactor programs by safely and cost effectively receiving and storing used fuel elements from foreign and domestic research reactors, pending disposition. Currently, UNF is stored at the L-Area Complex. More information can be obtained by viewing the L-Area Complex fact sheet at SRS's website at http://www.srs.gov/general/news/ factsheets/esrs_lac.pdf.

\section{Waste Management}

SRS manages large volumes of radiological and nonradiological waste created by previous operations at the nuclear reactors and their support facilities, as well as newly generated waste created by ongoing Site operations. Specific waste management initiatives are described below.

\section{Radioactive Liquid Waste Management}

Radioactive liquid waste is generated at SRS as byproducts from the processing of nuclear materials for national defense, research, and medical programs. It is stored in underground tanks in the F- and H-Area Tank Farms. A total of approximately 37 million gallons of radioactive liquid waste is safely stored in 44 tanks.

Of the seven unused tanks, two tanks (17F and 20F) were operationally closed in 1997, two tanks (18F and 19F) were operationally closed in 2012, two tanks (5F and 6F) have been emptied and undergoing preparations for operational closure in 2013, and one tank (16F) was emptied and removed from service in 1972. 
While waste is stored in the tanks, sludge settles by gravity to the bottom of the tank and a liquid (salt), known as supernate, resides on top of the sludge. The supernate is reduced by evaporation and the condensed vapors are transferred to the Effluent Treatment Project (ETP) for treatment. The concentrated salt that remains is transferred to the Salt Disposition Process (SDP). The SDP consists of the Actinide Removal Process (ARP) and Modular Caustic Side Solvent Extraction Unit (MCU). The two systems work together as an integrated process to remove nearly all of the radioactive isotopes from salt. The low-activity decontaminated salt is then sent to the Saltstone Production Facility (SPF), where it is mixed with cement, ash, and furnace slag and poured into permanent concrete vaults for safe disposal, at the Saltstone Disposal Facility. The high-activity contaminates that were removed at ARP and MCU are transferred along with the tank sludge for treatment at the Defense Waste Processing Facility (DWPF). At DWPF, the waste is treated and converted into a solid glass form suitable for long-term storage and disposal. This solidification process is also known as vitrification. More information can be obtained by viewing the Radioactive Liquid Waste Disposition page at SRS's website at http://www.srs.gov/general/programs/liquidwaste/index.htm and the Waste Solidification pages at http://www.srs.gov/general/programs/solidification/index.htm.

SRS waste tanks have provided more than 50 years of safe storage for radioactive liquid waste. Removing waste from the tanks will allow for permanent closure of the Site's radioactive liquid waste tanks, a high priority for DOE. More information can be obtained on SRS's website at http://www.srs.gov/general/news/factsheets/lnwtc.pdf.

\section{Solid Waste Management}

Solid wastes managed at SRS include the following types:

- Low-level radioactive solid waste, which includes items such as protective clothing, tools and equipment that have become contaminated with small amounts of radioactive material;

- Transuranic (TRU) waste, which contains alpha-emitting isotopes with an atomic number greater than uranium;

- Hazardous waste, which is any toxic, corrosive, reactive, or ignitable material that could affect human health or the environment;

- Mixed waste, which contains both hazardous and radioactive components; and

- Sanitary waste, which like ordinary municipal waste, is neither radioactive nor hazardous.

All wastes generated at SRS are treated, stored, and disposed to meet environmental and regulatory requirements. The Site also emphasizes waste minimization and recycling as a way to reduce the volume of waste that must be managed. More information can be obtained by viewing the Solid Waste Management page on SRS's website at

http://www.srs.gov/general/programs/solidwaste/index.htm.

\section{Area Completion}

Past operations at SRS have resulted in the release of hazardous and radioactive substances to soil and groundwater, with contamination levels exceeding regulatory limits. The purpose of the Area Completion program is to deactivate and decommission contaminated facilities and remediate (if necessary) soils, groundwater, surface water, and sediments to levels that are protective of human health and the environment.

SRS has pioneered a number of technologies to increase the effectiveness of SRS's remediation efforts to reduce human health and environmental impacts of legacy material. During characterization or remediation of waste sites, SRS uses a Green Remediation approach to reduce greenhouse gas and other emissions that may have negative environmental consequences. Green Remediation is the practice of (1) considering all the environmental effects of remedy implementation and (2) incorporating options to minimize the environmental footprints of cleanup actions.

Natural remedies used at SRS include phytoremediation (augmented natural vegetative processes), bioremediation (augmented naturally occurring microbial processes), and natural attenuation (natural processes to address contamination). These technologies are proving to be a cost-efficient means to expedite the reduction of risks to human health and the environment. 
SRS uses a streamlined cleanup strategy to accelerate work and reduce overall lifecycle costs. A key component of this approach is the use of a core team process with the U.S. Environmental Protection Agency (EPA) Region 4 and SCDHEC. In reaching such decisions public and stakeholder (such as the Citizens Advisory Board [CAB]) input is solicited and considered.

During 2012, SRS completed soil removal activities and implementation of additional access controls along Lower Three Runs (stream) and in-situ decommissioning of the C-Reactor Disassembly Basin. More information can be obtained by viewing the Area Completion Projects page on SRS's website at

http://www.srs.gov/general/programs/soil/extpage.html.

\section{Effluent Monitoring and Environmental Surveillance}

SRS personnel conduct extensive environmental monitoring within a 2,000 square-mile network extending 25 miles from SRS, with some monitoring performed as far as 100 miles from the Site. This area includes neighboring cities, towns, and counties in South Carolina and Georgia. Thousands of samples of air, rainwater, surface water, drinking water, groundwater, food products, wildlife, soil, sediment, and vegetation are collected by SRS and state authorities, and are analyzed for the presence of radioactive and nonradioactive contaminants. SRS sampling locations, sample media, sampling frequency, and types of analysis are selected based on environmental regulations, exposure pathways, public concerns, and measurement capabilities. The selections also reflect the Site's commitment to (1) safety, (2) protecting human health, (3) meeting regulatory requirements, (4) reducing the risks associated with past, present, and future operations, and (5) improving cost effectiveness.

\section{DOE NNSA Primary Site Activities}

\section{Tritium Processing}

Tritium is a radioactive form of hydrogen gas that is a vital component of nuclear weapons. Tritium has a half-life of 12.3 years and must be periodically replenished. SRS is the nation's only facility for extracting, recycling, purifying, and reloading tritium. Tritium is replenished by recycling tritium from existing warheads and by extracting tritium from target rods irradiated in nuclear reactors operated by the Tennessee Valley Authority. Recycled and extracted gases are purified to produce tritium suitable for use. SRS Tritium facilities are part of the NNSA's Defense Programs operations at SRS. More information can be obtained by viewing the Defense Programs page on SRS's website at http://www.srs.gov/general/programs/dp/index.htm.

\section{Defense Nuclear Nonproliferation}

SRS is one of the primary DOE sites with missions to address issues of national security and nonproliferation, including legacy material disposition. Currently under construction, the MFFF will convert excess weapons-usable plutonium to a form that can be used in commercial power reactors. Once irradiated, the plutonium can no longer be readily used for nuclear weapons. This critical facility, along with the associated Waste Solidification Building (WSB), are essential to U.S. plans to consolidate and dispose of surplus U.S. weapon-grade plutonium. More information can be obtained by viewing the MOX project website at http://www.moxproject.com. 
This page intentionally left blank. 


\section{ENVIRONMENTALMANAGEMENT \\ SYSTEM

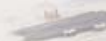 \\ Kim Cauthen \\ Environmental Compliance \& Area Completion Projects}

The Department of Energy (DOE) is committed to implementing sound stewardship practices that protect the air, 1 water, land, and other natural, archaeological, and cultural resources potentially impacted by Savannah River Site (SRS) construction, operations, maintenance, and decommissioning activities. A consistent site-wide implementation of an Environmental Management System (EMS) is a part of the overall Integrated Safety Management System (ISMS). The EMS provides for the systematic planning, integrated execution, and evaluation of SRS activities for: (1) public health and environmental protection, (2) pollution prevention and waste minimization, (3) compliance with applicable environmental and cultural resources protection requirements, and (4) continuous improvement of the EMS.

To manage operations and activities consistent with the overall goal of sound stewardship, the SRS EMS enables SRS to clearly identify and establish environmental goals, develop and implement plans to meet the goals, determine measurable progress toward the goals, and take steps to ensure continuous improvement. SRS continues to be compliant with the DOE EMS requirements.

\section{SRS EMS Implementation}

EMS is a recognized business tool that has a well-developed structure and format that reflects the best environmental and sustainability practices. As such, DOE has integrated the specific framework provided by DOE Order 450.1A, "Environmental Protection Program," into the current management practices and procedures at SRS. While there are a number of acceptable EMS models, each follow a similar format. The framework chosen by DOE is the International Organization for Standardization (ISO) Standard 14001 (Environmental Management Systems). The ISO 14001 model employs a cycle of policy development, planning, implementation and operation, checking, and corrective action, and management review. The ultimate goal is to improve environmental performance as the cycle repeats.

In accordance with the requirements of DOE Order 450.1A, an independent team of assessors conducted an audit of the Savannah River Nuclear Solutions, LLC (SRNS), and Savannah River Remediation LLC (SRR), EMS for conformance to the requirements of ISO 14001 in April 2012. An opportunity for improvement related to the documentation of communications was identified during the audit and immediately implemented. On June 15, 2012, the Department of Energy-Savannah River Operations Office (DOE-SR) determined that the EMS for both contractor organizations met the ISO 14001 requirements and issued a formal "Declaration of Conformance." The next scheduled external audit will be in 2015. Multiple contractors implement EMS at SRS using documents, programs, and with individual strategies tailored to organization-specific activities. DOE-SR oversees the implementation of each strategy to ensure a consistent, integrated Site program. This chapter provides highlights of these programs.

Documentation of the implementation strategy for SRNS and SRR is in the "Environmental Management System Description Manual” (G-TM-G-00001). This manual is located on the SRS website at http://www.srs.gov/general/pubs/ envbul/documents/ems_manual.pdf. Wackenhut Services Inc. (WSI-SRS), and Shaw AREVA MOX Services, LLC maintain EMS programs in compliance with DOE Order 450.1A and their individual contract-specific requirements.

\section{Integration of the SRS EMS within ISMS}

The objective of the Integrated Safety Management System (ISMS) program is to perform work in a safe and environmentally sound manner. More specifically, DOE and its contractors must integrate safety into management and work practices at all levels so that missions are accomplished while protecting the worker, the public, and the environment. 


\section{INTEGRATION OF SRS EMS INTO ISMS}

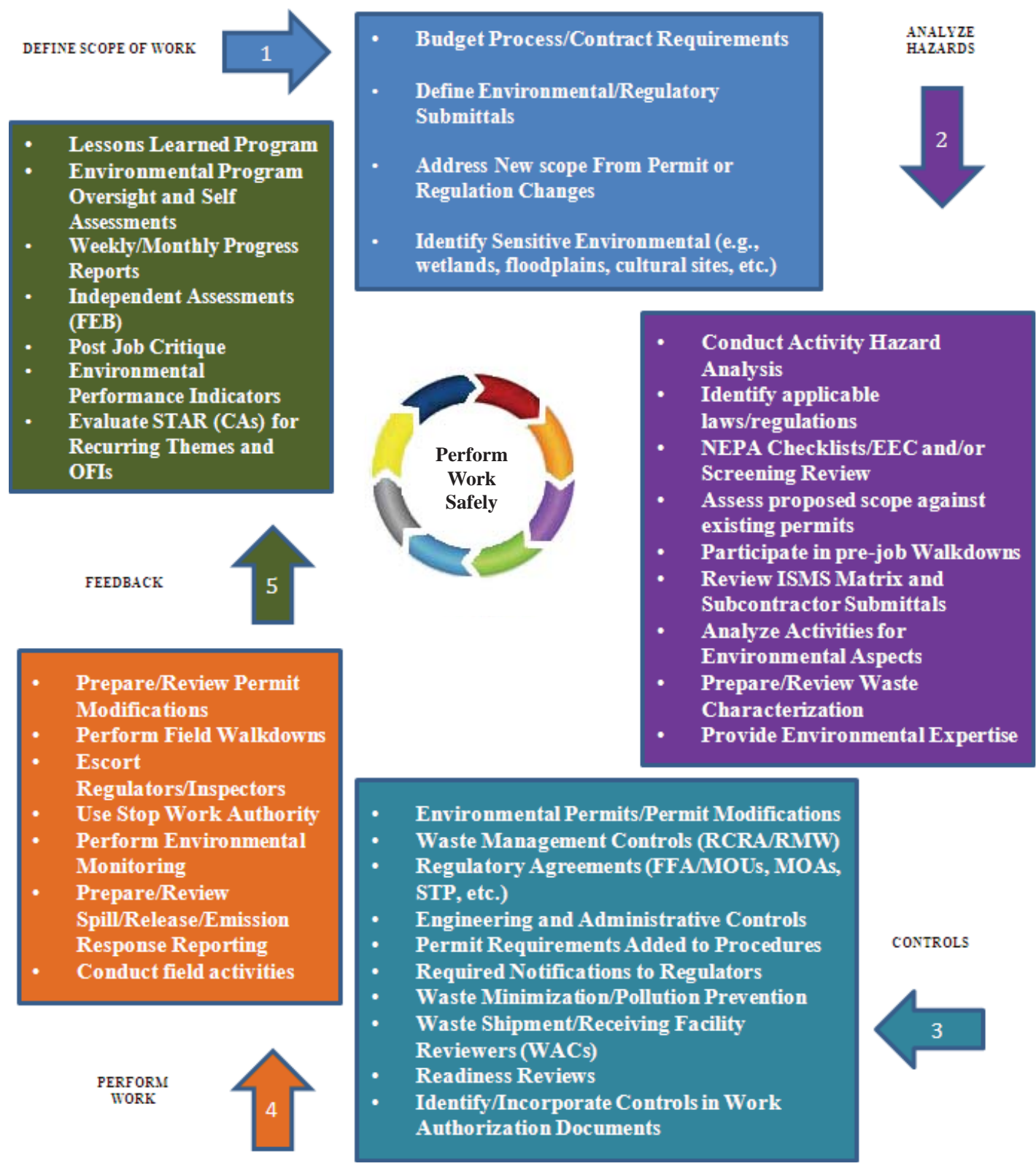

Figure 2-1 Environmental Management System Integration

Figure 2-1 depicts the processes for integrating EMS activities into the SRS ISMS program. All SRS organizations follow this approach and include environmental and regulatory requirements into their programs and procedures.

\section{Environmental Policy}

The SRS Environmental Policy documents SRS's intent to implement sound stewardship practices that protect the air, water, land, and other natural and cultural resources potentially impacted by SRS construction operations, maintenance, and decommissioning activities. The policy is reviewed annually and updated as needed. Chapter 6 of the SRS Policy Manual on the DOE-SR website at http://sro.srs.gov/pdf_files/SRSPM_250_1_1A.pdf contains the current policy. 


\section{Objectives, Targets, and Programs}

Through the EMS, SRS organizations set new goals and targets on an annual basis in support of DOE environmental objectives.

Twelve specific objectives and targets were established for 2012. These targets and a summary of SRS's progress in achieving them are shown in Table 2-1.

Table 2-1 2012 SRS EMS Targets (Summary)

\begin{tabular}{|l|}
\hline \multicolumn{1}{|c|}{ EMS Target/Objectives } \\
\hline $\begin{array}{l}\text { Reduce Scope } 1 \text { and } 2 * \text { greenhouse gas emis- } \\
\text { sions by } 28 \%\end{array}$ \\
\hline $\begin{array}{l}\text { Provide } 7.5 \% \text { of electricity utilization from re- } \\
\text { newable energy sources }\end{array}$
\end{tabular}

Reduce the potable water consumption by $26 \%$ (gal per gross square foot) by FY 2020 from a FY 2007 baseline.

Expand purchases of Environmentally Preferable Purchasing (EPP) products

\section{This} to startup of the new Biomass Cogeneration Facility (BCF) in
FY 2012. SRS has four biomass facilities in operation (BCF, A Area, K Area, and L Area); all site coal-fired plants have been retired.

$13.9 \%$ of the electrical consumption at SRS was from renewable energy sources due to the operation of the new BCF in FY 2012 and the shutdown of the D-Area coal boilers.

SRS has realized a $10.9 \%$ decrease in potable water consumption since FY 2007 mainly due to population reductions and some conservation measures such as low flow devices.

SRS includes a requirement to use EPP in all new applicable solicitations. At least $95 \%$ of applicable solicitations included the EPP clause.

SRS began implementation of a new business system implemented that provides a mechanism to track requisitions.

Reduce the use of hazardous materials and toxic chemicals by:

1. Reducing the volume of hazardous and radioactive generated waste by $10 \%\left(357 \mathrm{~m}^{3}\right)$

2. Achieving a minimum of $35 \%$ recycle rate for routine sanitary waste

3. Reducing the purchase of chemicals with hazard rating 3 or 4 by $5 \%$

Reduce consumption of fleet petroleum by $30 \%$ by FY 2020 relative to the baseline of FY 2005

Minimize pollution associated with stormwater runoff

Purchase at least $95 \%$ of electronic products that meet Electronic Product Environmental Assessment Tool (EPEAT) standards
1. Pollution Prevention projects during the year resulted in the reduction of $3,822 \mathrm{~m}^{3}$ of hazardous and radioactive waste generated.

2. SRS documented a recycle rate of $43 \%$, equal to 730 metric tons, of routine sanitary waste diverted to recycle markets.

3. The Chemical Management Center (CMC) reduced the number of high hazard chemical procurements in 2012 by $39 \%$ over purchases made in 2011. Additionally, the CMC distributed for reuse more than 35,900 lbs of chemicals in 2012, avoiding more than $\$ 450,000$ in chemical acquisition and waste management costs.

SRS fleet petroleum use was reduced approximately 19\% (FY 2012 vs. FY 2005). SRS E85 use has increased by nearly 300\% since FY 2000.

Best Management Practices for stormwater runoff pollution prevention were reviewed during the year to ensure releases and contaminant discharges were minimized. Additional inspections were conducted and any deficiencies documented and corrected.

EPEAT standards currently apply only to laptop computers and desktop monitors. $100 \%$ of laptop computers and desktop monitors acquired for use by SRNS/SRR meet EPEAT standards. 
Table 2-1 2012 SRS EMS Targets (Summary) (Continued)

\begin{tabular}{|l|l|}
\hline \multicolumn{1}{|c|}{ EMS Target/Objectives } & \multicolumn{1}{c|}{ Status } \\
\hline $\begin{array}{l}\text { Increase fleet non-petroleum based fuel con- } \\
\text { sumption by 10\% annually while decreasing total } \\
\text { consumption of petroleum-based fuels }\end{array}$ & $\begin{array}{l}\text { The use of alternative fuels at SRS has increased dramatically } \\
\text { in recent years. Approximately 77\% of vehicles in the light duty } \\
\text { fleet currently utilize E85 fuel or are gasoline hybrids. The Site } \\
\text { works to ensure the use of alternative fuels remains high by pri- } \\
\text { oritizing use of flex fuel and hybrid vehicles. In the initial year } \\
\text { of alternative fuel use (FY 2000), SRS consumed about 80,000 } \\
\text { gallons of E85 fuel. In FY 2012, the consumption of E85 fuel } \\
\text { total rose to well over 300,000 gallons. The result is an increase } \\
\text { of nearly 300\% since initiation of this fuel choice. }\end{array}$ \\
\hline $\begin{array}{l}\text { Evaluate planned work and conduct environmen- } \\
\text { tal studies to ensure offsite impacts from SRS ac- } \\
\text { tivities are minimized }\end{array}$ & $\begin{array}{l}\text { Offsite monitoring to assess impacts, if any, continued during } \\
\text { FY 2012. Periodic reviews of the program ensure appropriate } \\
\text { environmental media sampling and reporting. Details are con- } \\
\text { tained in Chapter 5, "Environmental Surveillance," of this re- } \\
\text { port. National Environmental Policy Act (NEPA) evaluations } \\
\text { and decisions concerning planned activities at SRS were com- } \\
\text { pleted in 2012 and with detailed discussions in detail in Chapter } \\
\text { 3, “Compliance Summary,” of this report. }\end{array}$ \\
\hline $\begin{array}{l}\text { Prevent occurrence of and minimize the severity } \\
\text { of spills through proper handling of materials and } \\
\text { wastes }\end{array}$ & $\begin{array}{l}\text { No reportable spills occurred during the year. Plans to prevent } \\
\text { and minimize spills were reviewed and updated. }\end{array}$ \\
\hline $\begin{array}{l}\text { Maintain regulatory compliance } \\
\text { *Scope 1 consists of direct emissions such as onsite combustion or fossil fuels or fugitive greenhouse gas emissions } \\
\text { Scope 2 consists of indirect emissions associated with the consumptions of electricity, heat, or steam }\end{array}$ \\
\hline
\end{tabular}

\section{Competence, Training, and Awareness}

SRS employees receive general environmental awareness training annually. Additionally, SRS subject matter experts offer specialized environmental and waste management training, as needed. Regularly scheduled classes ensure that operations and maintenance personnel, as well as environmental professionals, have the knowledge and skills to perform work safely and in a manner that protects the environment in and around SRS.

\section{Resources, Roles, Responsibilities, and Authority}

All SRS employees have specific roles and responsibilities in key areas, including environmental protection. Environmental and waste management technical support personnel assist Site operating organizations with identifying and meeting their environmental responsibilities. SRS maintains detailed manuals on resources, roles, responsibilities, and authority to assist employees in performing their duties.

\section{Communications}

SRS continues to maintain and improve internal and external communications on environmental issues. SRS solicits input from interested parties such as community members, activists, elected officials, and regulatory agencies. As an example, the SRS Citizens Advisory Board (CAB) provides advice and recommendations to DOE in many areas of SRS operations including environmental matters. Other external communications include Environmental Justice community meetings, websites, environmental bulletins, and social media. Internal SRS forums associated with environmental issues include:

- SRS Senior Environmental Managers Council (SEMC) composed of senior-level environmental managers (from all SRS contractors) who share information on environmental concerns and regulatory matters.

- DOE-SR Environmental Quality Management Division (EQMD) environmental oversight staff meets regularly with SRS contractors to discuss issues relevant to environmental protection and compliance. 
- SRS Regulatory Integration Team (SRIT), consisting of DOE-SR, the U.S. Environmental Protection Agency (EPA) Region 4, and South Carolina Department of Health and Environmental Control (SCDHEC) representatives, address crosscutting issues that require high-level agency collaboration.

- Site Joint Regulatory Integration Team (SJRIT), consisting of senior representatives from the various DOE-SR program offices, meets routinely to discuss emerging environmental issues and develop common strategies for interactions with the regulatory agencies and stakeholders with regard to site wide issues.

- Challenges, Opportunities, and Resolution (COR) Team, consisting of regulatory compliance representatives of SRNS and other major SRS contractors, discuss emerging compliance or implementation challenges and opportunities to develop and coordinate resolutions.

\section{Operational Controls}

Operational controls help ensure that regulatory compliance, pollution prevention, and continuous improvement plans are in place and implemented. One of the more significant operational controls is the required use of the Environmental Evaluation Checklist (EEC) process. Initiation of an EEC occurs when a new process or activity is considered or a change to an existing operation is proposed. The EEC process provides timely identification of regulatory requirements and potential impacts on the environment.

\section{Emergency Preparedness and Response}

The SRS Emergency Plan (SRS EP, 2013) specifies procedures to facilitate the identification of emergencies and accidents that could affect the environment and provides definitions of appropriate responses and reporting criteria for such situations and accidents.

\section{Monitoring and Measuring}

The "SRS Environmental Monitoring Program Management Plan" (SRS EM Plan, 2013) documents the rationale, objectives, and activities associated with the routine effluent monitoring and environmental surveillance programs. The purpose of these programs is to demonstrate compliance with regulatory and DOE requirements as well as determine, if any, the effects of SRS operations to the public and on the environment. Additional information on effluent monitoring, environmental surveillance, and groundwater monitoring is located in Chapter 4, "Effluent Monitoring," Chapter 5, "Environmental Surveillance,” Chapter 7, “Groundwater,” and, Chapter 9, "Special Studies,” of this report.

\section{Evaluation of Compliance}

Evaluation and assessment of specific environmental laws and regulations occurs on a program- or facility-specific basis periodically. Environmental support organizations conduct regulatory assessments in selected topical areas to verify compliance. External regulatory agencies and/or technical experts may also perform independent compliance audits. Additional information on environmental compliance is in Chapter 3, "Compliance Summary," of this report.

\section{Nonconformity, Corrective Action, and Preventive Action}

Nonconformity, corrective action and preventive action are part of the SRS Quality Assurance (QA) Program and included in the EMS. Instances of nonconformance identified by assessments and evaluations are recorded and addressed according to established procedures. Additional QA information is in Chapter 8, "Quality Assurance," of this report.

\section{Control of Records and Documents}

The SRS EMS reflects the identification, maintenance, and disposition of environmental records and documents required by environmental regulations and DOE directives. The SRS Records Management (RM) program satisfies the requirement for management of environmental records. 


\section{Internal Audits}

DOE and contractor assessment programs are used to verify that the Site's EMS is functioning as intended. Performance assessments include performance objectives and criteria for management system review. Self-assessments are conducted in accordance with approved assessment plans. SRS conducts independent performance-based assessments for Site programs to satisfy contractual and regulatory obligations.

\section{Management Review}

The SRS Environmental Policy requires periodic evaluations of EMS effectiveness. Senior management reviews the EMS to ensure its continuing suitability, adequacy, and effectiveness. Reviews include assessing opportunities for improvement and the need for changes to the EMS. Retention of records of management reviews is in accordance with applicable procedures.

\section{Sustainability Accomplishments}

\section{Pollution Prevention/Waste Minimization}

SRS strives to prevent or reduce pollution and waste generation at its source whenever feasible. In 2012, the Site's $10 \%$ waste reduction goal for hazardous and radioactive waste equated to 487 cubic meters $\left(\mathrm{m}^{3}\right)$ based on forecasted generation rates. During the year, implementation of pollution prevention (P2) projects resulted in the avoidance or diversion of 3,822 $\mathrm{m}^{3}$ of hazardous and radioactive waste. The annual cost avoidance resulting from these projects is nearly \$5.1 million. Table 2-2 shows a summary of the 2012 P2 and waste minimization projects and their contributions.

Concurrently, SRS annually establishes a performance target for recycling its routine office-type sanitary waste stream. For 2012, the waste recycle target was 35\% and SRS achieved a recycle rate of $43 \%$ for this stream. This equals 730 metric tons of routine sanitary waste diverted to recycle markets. In addition, SRS diverted 14 metric tons of shredded wood waste, 465 metric tons of scrap metal, 69 metric tons of scrap electronics, and 130 metric tons of scrap furniture. The Chemical Management Center (CMC) distributed for reuse more than 35,900 pounds of chemicals in 2012, thus avoiding more than $\$ 450,000$ in chemical acquisition and waste management costs.

Table 2-2 2012 SRS Pollution Prevention Activities

\begin{tabular}{|c|c|c|c|}
\hline Activity Description & $\begin{array}{l}\text { Waste } \\
\text { Type }\end{array}$ & $\begin{array}{l}\text { Waste Vol. } \\
\text { Reduction } \\
\qquad\left(\mathrm{m}^{3}\right)^{*}\end{array}$ & $\begin{array}{l}\text { Annualized } \\
\text { Savings** }\end{array}$ \\
\hline L-Area 85/30 Ton Crane Rad Cleared for Release & LLW & 26 & $\$ 20,050$ \\
\hline Mercury Float Recycle & HAZ & 1 & $\$ 2,600$ \\
\hline $\begin{array}{l}\text { Decontamination and Disposal of Steel from H Tank Farm to Construc- } \\
\text { tion and Demolition Landfill }\end{array}$ & LLW & 29 & $\$ 22,600$ \\
\hline $\begin{array}{l}\text { Established new position for the Hot Crane in the Hot Crane Maintenance } \\
\text { Area (HCMA) to reduce breathing air hose use }\end{array}$ & LLW & 15 & $\$ 33,387$ \\
\hline Recycle DOE Moratorium and Suspension Lead & Mixed & 14 & $\$ 18,612$ \\
\hline Decontamination and Reuse of Contactors & LLW & 4 & $\$ 3,132,120$ \\
\hline Tritium Operations LLW Segregation & LLW & 13 & $\$ 18,970$ \\
\hline Railroad Rails Decontaminated and Released to Sanitary Landfill & LLW & 4.8 & $\$ 6,650$ \\
\hline Defense Waste Processing Facility Waste Fuel Reused @ A Area & HAZ & 32 & $\$ 23,400$ \\
\hline
\end{tabular}


Table 2-2 2012 SRS Pollution Prevention Activities (Continued)

\begin{tabular}{|c|c|c|c|}
\hline Activity Description & $\begin{array}{l}\text { Waste } \\
\text { Type }\end{array}$ & $\begin{array}{l}\text { Waste Vol. } \\
\text { Reduction } \\
\qquad\left(\mathrm{m}^{3}\right)^{*}\end{array}$ & $\begin{array}{l}\text { Annualized } \\
\text { Savings** }\end{array}$ \\
\hline $\begin{array}{l}\text { Savannah River National Laboratory (SRNL) Radiological Area } \\
\text { Recovery }\end{array}$ & LLW & 16 & $\$ 29,470$ \\
\hline In-situ Waste Disposal in 105-C Disassembly Basin & LLW & 68 & $\$ 90,240$ \\
\hline PCB Fluids and Equipment Recycle & PCB & 226 & $\$ 800,000$ \\
\hline Tritiated Debris Thermal Treatment Project & LLW & 3,375 & $\$ 900,000$ \\
\hline Totals & & $3,822 \mathrm{~m}^{3}$ & \$5.1 million \\
\hline \multicolumn{4}{|l|}{$\begin{array}{l}\text { Vaste as defined by the Resource Conservation } \\
\text { contains both radioactive and hazardous wastes } \\
\text { ted biphenyl containing wastes }\end{array}$} \\
\hline
\end{tabular}

\section{Energy Intensity}

Energy intensity is the energy consumption per square foot of building space, including industrial and laboratory facilities. DOE is required to reduce its energy intensity by 30\% by FY 2015 from a FY 2003 baseline. SRS is well ahead of the curve in energy intensity reduction. SRS energy intensity has been drastically reduced over many years. Energy intensity has been reduced 91\% since 1985 and 43\% vs. the current requirement based on the 2003 baseline. Figure 2-2 illustrates this comparison against the current baseline.

\section{DOE-SR Performance Toward} $30 \%$ Energy Reduction Goal

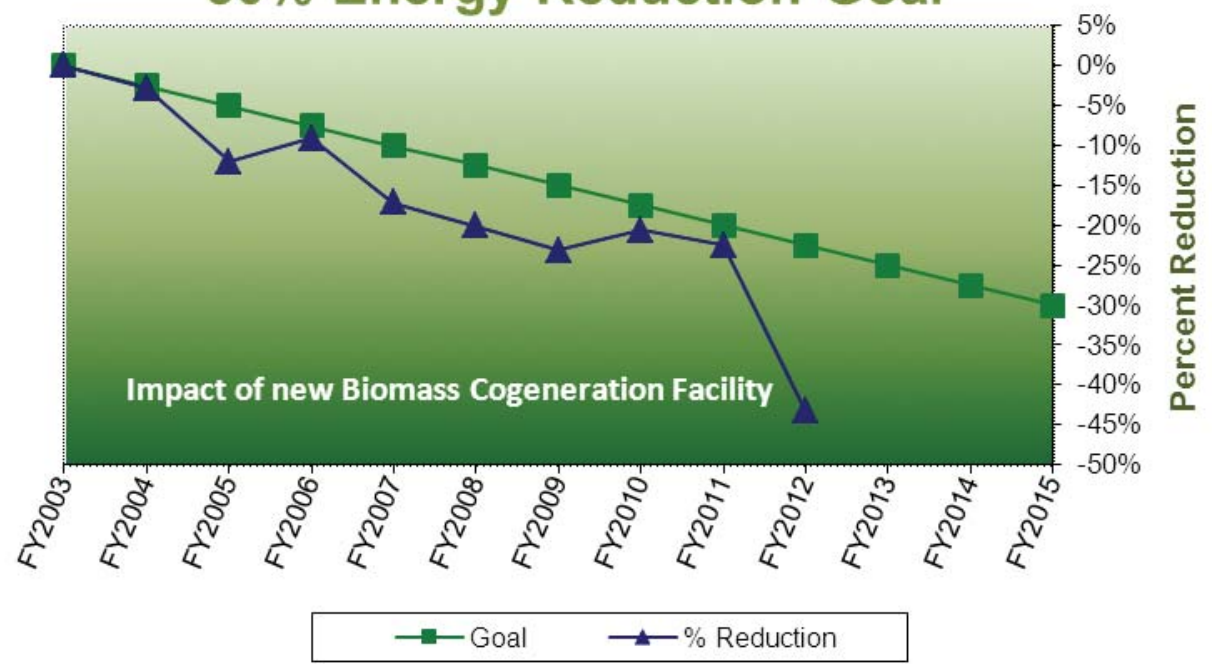

Figure 2-2 DOE-SR Energy Reduction Performance 
SRS conducted many activities in 2012 that reduced energy intensity:

- Completed startup and six months of operations of the new Biomass Cogeneration Facility. This had the most impact on the energy intensity reduction at SRS in 2012. Steam and electricity output from the plant are not included in the intensity metric because the plant is a renewable energy source;

- Completed the installation of several heating, ventilation, and air conditioning (HVAC) units with new, higher Seasonal Energy Efficiency Ratio (SEER) units;

- $\quad$ Reduced fuel oil use by over $30 \%$ at the A-Area biomass plant while increasing the use of wood/biomass;

- Conducted energy audits and building commissioning evaluations in approximately 540,000 square feet as part of sustainable building efforts;

- Conducted Energy Independence and Security Act of 2007 (EISA) audits in approximately 2.4 million square feet;

- Initiated multiple peak alerts during the summer months;

- Installed new electrical meters;

- Utilized cool roofs on roof replacements; and

- Replaced air compressors and air dryers in Building 775-A.

SRS conducted many significant activities in energy intensity reduction specifically in the Tritium facilities in 2012 including:

- Installing two electricity meters at 248-H to measure Power Usage Effectiveness (PUE) in the Classified and Unclassified Computer Rooms;

- $\quad$ Replacing 235-H rooftop HVAC units for improved efficiency and reliability;

- Continuing progress on an ice storage chilled water system project for 234-7H. This system is a pilot application of using ice storage to support a process facility;

- Performing condenser coil cleaning on multiple air-cooled HVAC units for improved efficiency and reliability; and

- Preparing a path forward for converting older fluorescent light fixtures to the higher efficiency design.

\section{Renewable Energy}

A variety of laws, regulations, and DOE Orders encourage the use of renewable energy sources such as biomass fuels. Using Energy Saving Performance Contracts (ESPC) new steam and electrical generation facilities have been constructed at SRS that use biomass as the primary fuel. This has eliminated coal as a source of energy at SRS. SRS has four biomass steam plants in permanent operation in A Area, L Area, K Area, and F Area. Ameresco Federal Solutions, Inc. (Ameresco) began operation of the new Biomass Cogeneration Facility near F Area in 2012.

The thermal-only steam plant in A Area (Figure 2-3) utilizes biomass as the primary fuel source. Early 1950's vintage coal-fired boilers were replaced with new state-of-the-art boilers and emission controls while maintaining steam

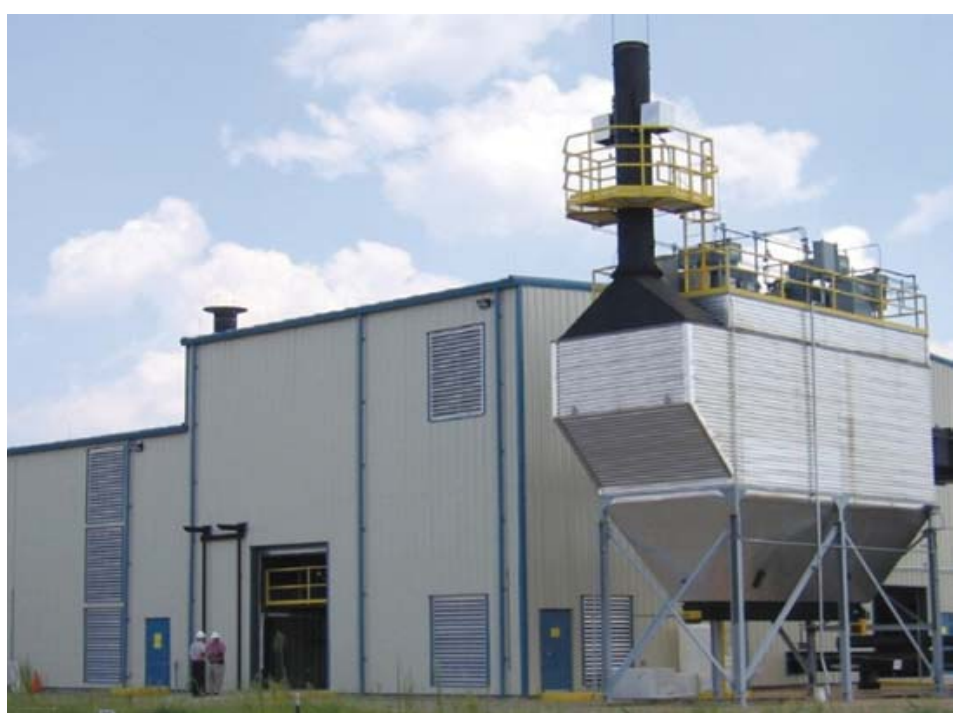

Figure 2-3 A-Area Biomass Steam Plant availability around-the-clock at minimum cost. Installation of this plant utilized the existing ESPC in place at SRS. The total cost of the project was $\$ 13.8$ million and annual savings average over $\$ 1.5$ million. The facility will be paid for (term of the contract) in nine years. 
The renewable and environmental aspects of the A Area biomass project are numerous:

- Utilization of coal is reduced by over 12,000 tons annually.

- Utilization of biomass is increased by nearly 27,000 tons annually.

- Particulate Matter (PM) emissions reduced from 411 tons/year to 7.36 tons/year and PM-10 microns from 300 tons/year to 4.38 tons/year.

- $\quad$ Sulfur dioxide $\left(\mathrm{SO}_{2}\right)$ emissions are reduced from 1,836 tons/year to 4.38 tons/year.

- $\quad$ Nitrogen oxide ( $\mathrm{NO}_{\mathrm{x}}$ ) emissions are reduced from 256.7 tons/year to 35 tons/year.

- Carbon monoxide (CO) emissions are reduced from 120.8 tons/year to 105.1 tons/year.

- Ash generation and disposal is reduced.

- Compliance with Clean Air Act and Clean Water Act standards are achieved.

The new Biomass Cogeneration Facility in F Area will generate an estimated 77,500 MW-hours of electricity in its first year of operation. This production rate will be well above the $7.5 \%$ statutory goal for energy consumption that must come from renewable energy sources for 2013 and thereafter. DOE reimburses Ameresco from actual cost savings generated during the 15-year debt service payback period; the savings result from replacement of the Site's old and inefficient coal-fired plant. The benefits of the biomass facility include the use of wood vs. coal as a fuel source, location closer to the end users, and equipment designed to support the current steam and electrical needs of the Site. The surrounding communities also receive health and environmental benefits associated with the reduction in greenhouse gas emissions.

The K- and L-Area biomass plants continue to provide steam for heating during the winter months in those industrial complexes. These units replaced existing fuel oil fired heating units located in each area.

Some of the benefits of the Biomass Cogeneration Facility (Figure 2-4) and the biomass facilities in $\mathrm{K}$ and L Areas include:

- Reducing over 161,000 tons of annual coal consumption and 300,000 gallons of fuel oil consumption.

- Using 322,000 tons of biomass and bio-derived fuels per year.

- $\quad$ Reducing emissions:

- 400 tons/year - PM

- $\quad 3,500$ tons/year $-\mathrm{SO}_{2}$

- 2,500 tons/year - $\mathrm{NO}_{x}$

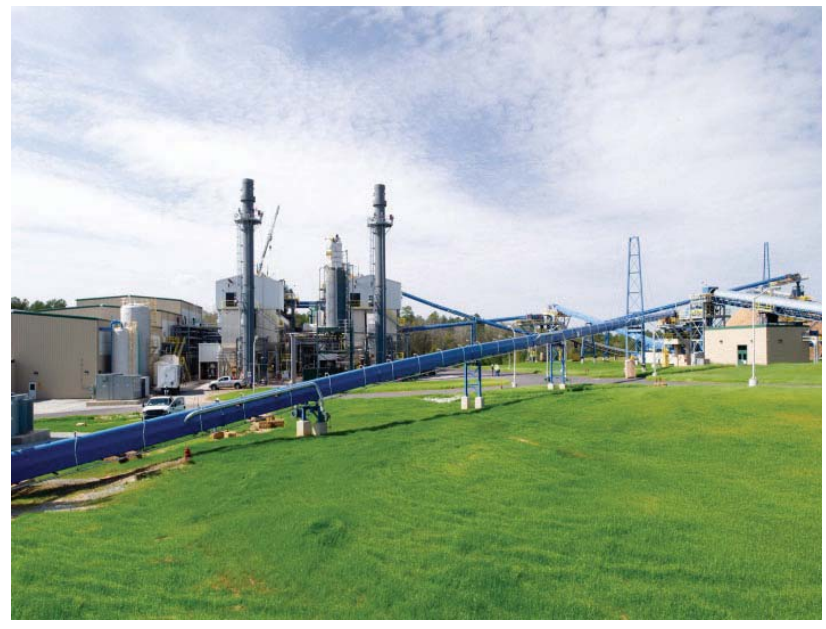

Figure 2-4 View of the Biomass Cogeneration Facility

- Reducing over one billion gallons of water pulled from the Savannah River annually.

- Reducing greenhouse gas (GHG) emissions by about 100,000 tons per year, significantly decreasing the carbon footprint of SRS (due to coal, a major contributor to greenhouse gases, being completely eliminated while maximizing the burning of wood).

- Meeting and exceeding renewable energy goals in federal directives, thereby serving as a key project for assisting DOE with achieving complex-wide renewable goals.

- Maintaining air quality standards through the reduction in Site air emissions.

- $\quad$ Supporting DOE initiative to be the lead federal agency in Renewable Energy Goals.

- Allowing SRS to permanently deactivate inefficient coal-fired boilers in D Area. 


\section{Greenhouse Gas Reduction}

SRS is committed to reducing GHG Scope 1 and 2 emissions by 28\% by fiscal year (FY) 2020 from the FY 2008 baseline. Scope 1 consists of direct emissions such as onsite combustion of fossil fuels or fugitive GHG emissions and Scope 2 consists of indirect emissions associated with the consumption of electricity, heat, or steam. Actual targets by DOE take into account new mission growth and other factors.

Ongoing organization of GHG data associated with the various impact sources, such as Site energy use and vehicle/ equipment use will allow for development of a comprehensive inventory and subsequent management.

Scope 1 and 2 GHG emissions are currently generated and inventoried from the following sources at SRS:

- Coal (although FY 2012 was the last year that coal was burned at SRS),

- Purchased electricity,

- Wood (biomass),

- Fuel oil,

- Propane,

- Hydrofluorocarbon (HFC),

- Gasoline,

- Diesel fuel,

- $\quad$ E85 (ethanol) fuel, and

- Jet fuel.

SRS has greatly reduced GHG emissions by transferring to a biomass-based energy supply versus the previous coalbased supply. GHG reduction benefits will be realized in FY 2013 and following years due to the operation of the existing three biomass plants and the recent addition of the biomass cogeneration facility.

\section{Water Management}

DOE is required to reduce potable water intensity by $26 \%$ by FY 2020 relative to the FY 2007 baseline. Compared to the baseline, SRS has currently reduced potable water intensity by 10.9\%. In FY 2012, low-flow toilet flush valves, low-flow urinal flush valves, and low-flow faucets continued to be installed as part of routine maintenance practices. In recent years, several hundred faucets and flush valves have been replaced with reducers or low-flow units.

Process water consumption decreased by 9.4\% in FY 2012 compared to the baseline usage in FY 2010. Changes during the year included adjustments in the process usage in $\mathrm{H}$ Area and D Area as well as reductions in Site water well pumpage rates. 


\section{Transportation and Fleet Management}

The primary DOE transportation and fleet management goals are to decrease fleet petroleum consumption by $2 \%$ annually by FY 2020 from the FY 2005 baseline and increase alternative fuel (E85) consumption by $10 \%$ annually by FY 2015 relative to the FY 2005 baseline.

The use of E85 fuel at SRS has increased dramatically in recent years while gasoline usage has decreased as shown in Figure 2-5. Approximately $80 \%$ of vehicles in the light duty fleet currently utilize E85 fuel or are gasoline hybrids. The Site works to ensure the use of E85 fuels remains high by prioritizing the use of flex fuel vehicles. In the initial year of E85 fuel use (FY 2000), SRS consumed about 80,000 gallons of E85 fuel. In FY 2012, this consumption total was well over 300,000 gallons (Figure 2-6).

SRS Fleet Management prepared a vehicle reduction plan to accomplish a $35 \%$ reduction in the number of fleet vehicles by the end of FY 2014. This plan provided details to reduce vehicle fleet size by $35 \%$ over 3 years, based on a 2005 fleet inventory baseline. SRS has exceeded the initial goal for FY 2012 and is on track to meet the $35 \%$ vehicle reduction plan by the end of FY 2014.

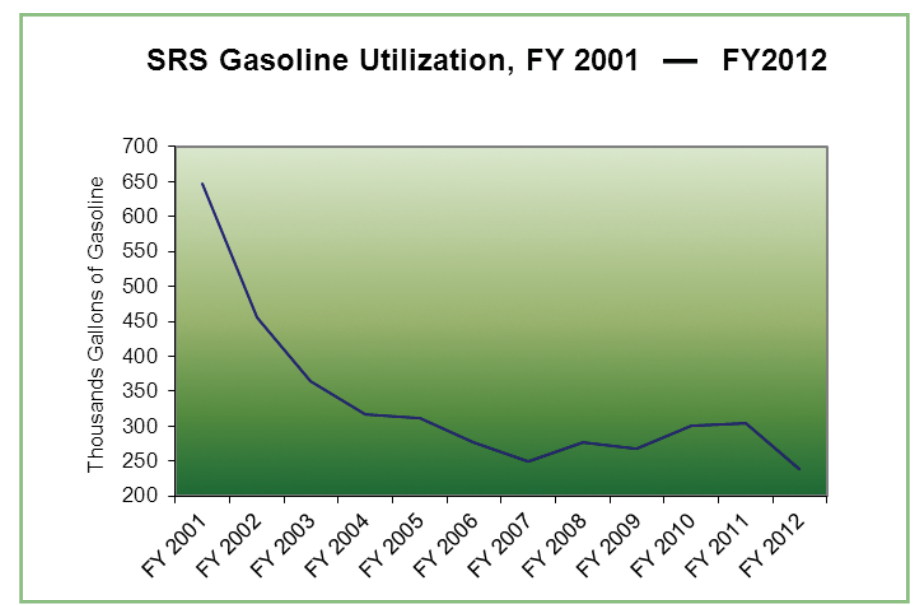

Figure 2-5 SRS Gasoline Reduction Performance

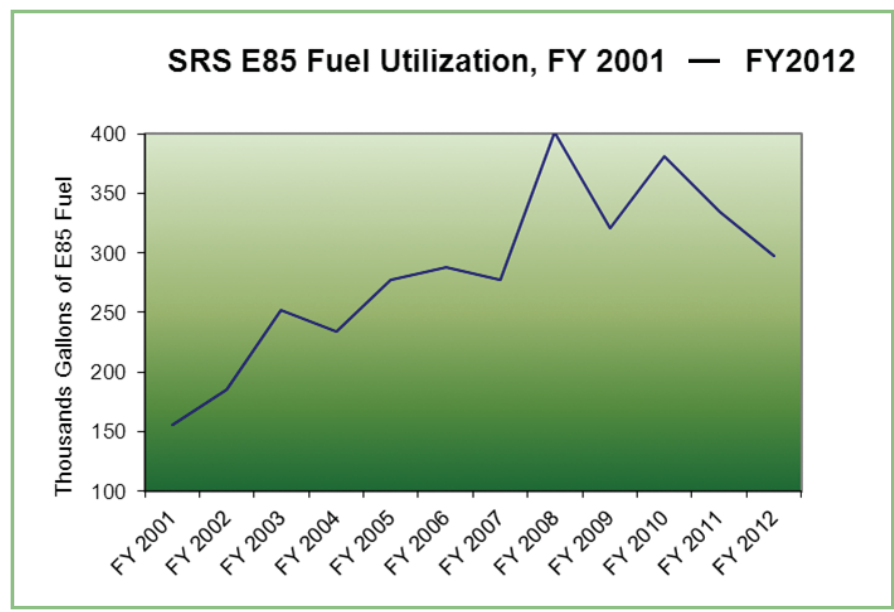

Figure 2-6 E85 Fuel Usage at SRS

\section{Contracts and Concession Agreements}

SRNS Supply Chain Management (SCM) has established sustainable acquisition practices for Environmentally Preferable Purchasing (EPP). At least 95\% of applicable solicitations included an EPP clause in FY 2012. Through this initiative, SCM has worked with other SRS entities (e.g., maintenance, engineering, and infrastructure organizations) during the performance of facility modifications to procure EPP alternatives as recommended and approved for Site use. Several practices have evolved relative to EPP procurements, including:

- The SRNS Chemical Management Center (CMC) reviews and approves all chemical acquisitions. This review monitors usage of hazardous chemicals and, where appropriate, recommends EPPs.

- Electronic stewardship has yielded the procurement/leasing of desktops, laptops, and monitors that meet EPEAT standards and copiers that are Energy Star compliant.

- Procurement of EPP substitutions under various new and existing contracts, including bulk janitorial supplies (e.g., cleaners, paper products) and safety items (e.g., earplugs, filters).

- Development and incorporation of an "Environmentally Preferable Purchasing" clause is invoked on all new applicable solicitations.

SRS will continue to evaluate and include environmental procurement requirements as existing contract(s) come up for renewal or rebid. 


\section{High-Performance Sustainable Buildings - New Construction}

DOE Order 430.2B “Departmental Energy, Renewable Energy, and Transportation Management,” stipulates that all new buildings and major renovations in the stages of pre-project planning through conceptual design that have not obtained preliminary design approval and that have a value exceeding \$5 million must achieve the U.S. Green Building Council’s Leadership in Energy and Environmental Design (LEED ${ }^{\circledR}$ ) Gold certification. In addition, to the extent possible and in consideration of life-cycle cost factors, such buildings must meet the guiding principles for federal leadership in High Performance Sustainable Buildings (HPSBs). Any buildings below or equal to the \$5 million threshold also must meet the guiding principles.

Although DOE Order 430.2B is not a specific requirement of the Shaw AREVA MOX Services prime contract, MOX Services strives to meet these objects for the construction of support facilities (MOX Services nuclear production facilities are built to meet missions and achieve Nuclear Regulatory Commission requirements). To this end, MOX Services Administration Building received LEED ${ }^{\circledR}$ Gold certification in FY 2010. In FY 2012, MOX Services applied for LEED ${ }^{\circledR}$ Gold certification for the new Technical Support Building.

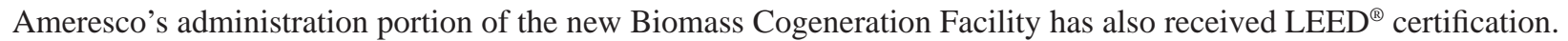
Design features of the new office space include a 6,000-gallon rainwater storage tank to reduce potable water usage for flushing fixtures and irrigation, permeable pavers in the parking lot to help control the volume of stormwater runoff, and the use of materials containing recycled content to improve the building's green footprint. Realization of energy savings are through efficient lighting and equipment, a variable speed drive for the water pump, and increased building insulation.

\section{Electronic Assets Management}

SRS continued to purchase EPEAT and other energy efficient electronic products during the year. Leasing of many of the personal computers allows for the return and redeployment of devices no longer needed at SRS.

\section{EMS Best Practices/Lessons Learned}

\section{Sustainability Campaign}

SRS continued implementation of the “One Simple Act of Green” environmental awareness campaign. The program targets specific items of sustainability and environmental stewardship that promote individual action by connecting SRS employees to information, tools, and programs that make a difference to our environment.

During 2012, several recommendations to SRS employees included:

- Using reusable shopping bags,

- Using programmable thermostats,

- Using energy efficient light bulbs,

- Waste recycling ideas,

- $\quad$ Turning off lights in unused room, and

- Green Christmas ideas.

Additional ideas and recommendations will be presented in 2013.

\section{Chemical Management Center}

The CMC provides centralized control of chemical materials procurement and management of excess chemical materials to reduce the volume and toxicity of the chemicals procured, reduce chemical inventories and waste, and improve tracking and communication of chemicals currently in onsite inventory. Hazardous and non-hazardous chemicals are reused onsite, returned to vendors when possible, sold through sealed bid sales to approved vendors, and donated to local government institutions to promote good community service while reducing waste generation. The CMC distributed for reuse more than 35,900 pounds of chemicals in 2012 and avoided more than \$450,000 in chemical acquisition and waste management costs. 


\section{Awards and Recognitions}

DOE recognizes significant contributions to Site missions that positively affect the local and surrounding environment. Site activities and projects are evaluated for noteworthy practices, implementation of new and emerging technologies, and insightful approaches to resolving environmental stewardship issues.

SRNS received recognition from the Georgia Clean Air Campaign for taking actions to improve air quality in Georgia and reduce traffic congestion on the roads in 2012. SRS has collaborated with the Georgia Clean Air Campaign since 2009 in an effort to reduce air pollution resulting from SRS employee travel.

Additionally, Shaw AREVA MOX Services maintained their membership in the South Carolina Department of Health and Environmental Control's South Carolina Environmental Excellence Program (SCEEP), which recognizes outstanding environmental leadership. SCEEP is a voluntary program recognizing South Carolina facilities that have demonstrated environmental performance through P2, energy and resource conservation, and the use of an EMS. Shaw AREVA MOX Services was invited and accepted into the program because of its effective implementation of a strong EMS and the absence of any violations of environmental regulations during the more than six years of site work and construction of the Mixed Oxide Fuel (MOX) project.

The DOE Office of Sustainability Performance Awards Programs recognized SRS projects with three national-level "DOE Sustainability Awards.” The winning nominations were the "SRS Biomass Steam and Co-generation Project," "SRS Moving Beyond Pump and Treat for cVOC Remediation Project," and the "SRS - An Innovative Approach for In-Situ Detection of Mercury in Soils and Sediments Project.” Only 20 "DOE Sustainability Awards” were granted from 137 nominations across the DOE complex. The three projects are described in more detail below and on the following page.

\section{Biomass Steam and Cogeneration Project}

This project utilizes the nation's largest ESPC to design, build, and operate three energy-efficient, biomass-fueled, renewable energy steam/cogeneration plants. Projected cost savings are approximately \$34 million annually with a reduction in GHG emissions of approximately 100,000 tons per year. This project represents a major environmental success for DOE and the federal government. This project was discussed in detail earlier in this chapter.

\section{Moving Beyond Pump and Treat for Chlorinated Volatile Organic Compounds Solvent Remediation Projects}

SRS successfully degraded a chlorinated volatile organic compounds solvent groundwater plume with edible oil injection. This project has enhanced attenuation of the plume and received regulatory support to achieve a final shutdown of an active pump and treat system. The enhanced attenuation approach reduced the size of the contaminated plume in a sustainable manner. A significant cost savings occurs by eliminating the operation and maintenance cost of the pump and treat system. The historical operating costs for the pump and treat system was approximately $\$ 1$ million per year. This approach will reduce the time for remediation and closure from over 30 years using pump, treat to approximately 10 years under monitored natural attenuation, and significantly reduce GHG emissions and energy consumption. 


\section{Innovative Approach for In-Situ Detection of Mercury in Soils and Sediments Project}

The Savannah River National Laboratory developed an innovative approach for the identification of elemental mercury in sediments and soils beneath former industrial facilities. The process uses commercial equipment developed for subsurface detection of volatile organic contaminants, expanding its application for use in the definitive detection of elemental mercury. This approach virtually eliminates the health risks associated with potential personnel exposure to hazardous mercury vapors and the need for the high cost treatment and disposal of mercury contaminated job control and sample residue wastes associated with drilling activities (Figure 2-7, 2-8).

Honorable mention was also received for the "SRS PCB Equipment Recycle” project.

SRS also won an EPA Federal Electronics Challenge "Bronze Award" for its sustainable electronics program incorporating procurement to end-of-life recycle.

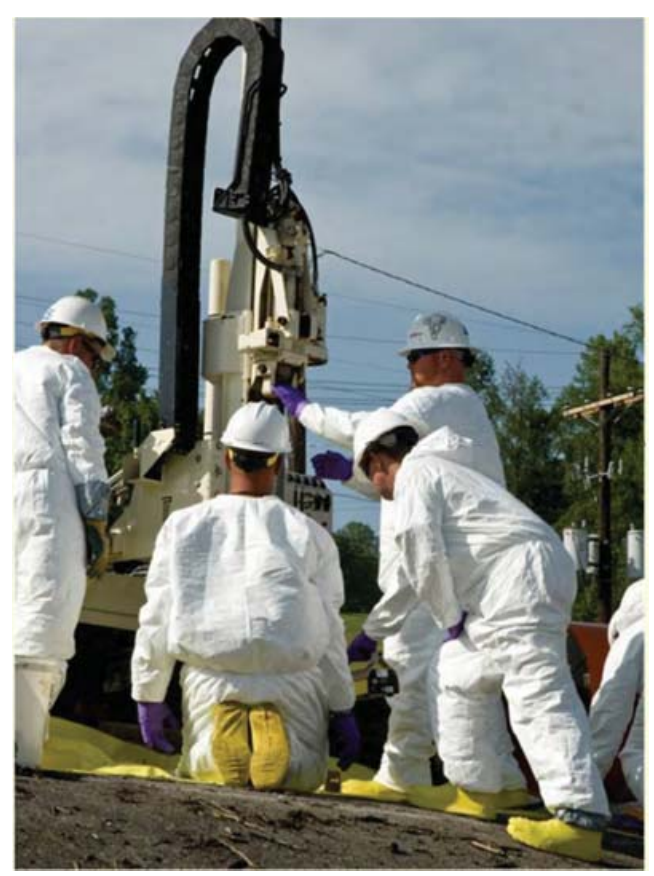

Figure 2-7 Mercury Characterization using Traditional Soil Sampling Techniques

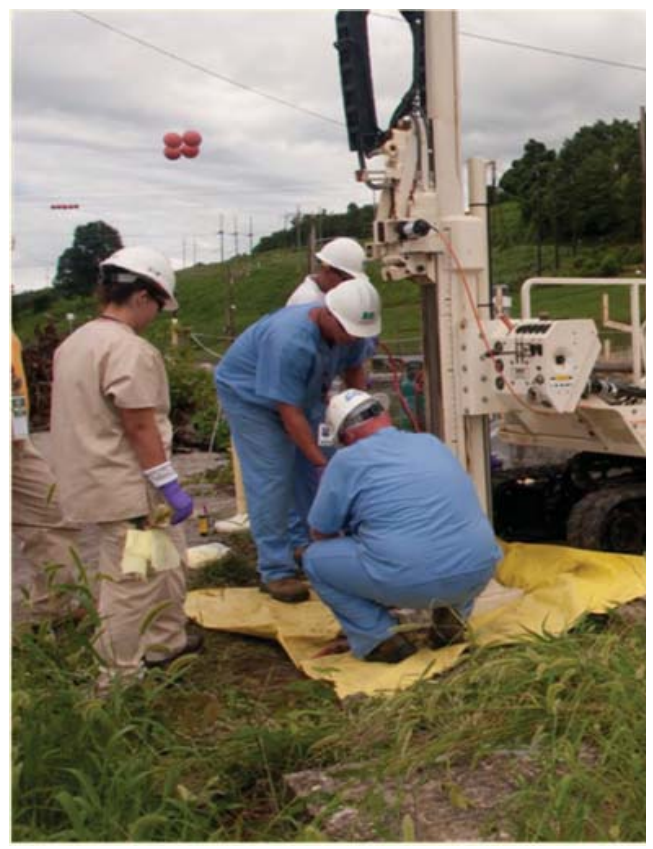

Figure 2-8 Mercury Characterization using Membrane Interface Probe system (Note reduction in the necessary protective clothing)

\section{Ongoing Environmental Enhancement Projects}

\section{SRS Vehicle Energy and Emissions Reduction}

Over the past decade, SRS successfully continued to maximize the use of E85 fuels. No appreciable percentage increase in use of this fuel is projected in 2013 since increases in previous years have been so dramatic. SRS will continue to prioritize acquisition of alternative fuel vehicles (AFV) and hybrids in the light-duty fleet based on General Services Administration (GSA) availability and use of the vehicles. Use of AFVs is the primary consideration when making decisions regarding the fleet.

In addition, SRS is working to secure an electric vehicle and charging station at the Site. This vehicle is a plug-in electric vehicle under the pilot program arrangement with GSA. This pilot will allow an increased number of federal agencies the opportunity to perform their missions while evaluating the application of advanced technology vehicles. The vehicle purchase and the charging station installation are expected in 2013. 


\section{Water Usage Reduction}

No appreciable percentage change in potable water intensity is projected for FY 2013. SRS will continue to install low-flow toilet flush valves, low-flow urinal flush valves, and low-flow faucets as part of fixture replacement, when needed.

\section{Greenhouse Gas Reduction}

The new Biomass Cogeneration Facility was operational in spring 2012. It is expected that the GHG emissions will further decline in 2013 following a full year of operation at the Biomass Cogeneration Facility and no coal usage. This is primarily a result of transitioning from a coal-based facility to a biomass energy source.

\section{Sanitary Waste Disposal}

In 2012, 730 metric tons of materials were recovered for recycling, representing 43\% of the sanitary waste stream. SRS received notice during mid-2012 that operation of the Three Rivers Material Recovery Facility (MRF) facility would be discontinued due to operational cost. Effective November 2012, SRS awarded a subcontract to the North Augusta MRF for routine sanitary waste stream recycle services.

\section{Computer Acquisition}

Purchasing of energy efficient computer products continues at SRS. Most computers are provided to Site employees via a lease agreement. Computer leases for the Site will continue to meet Energy Star, EPEAT, and low standby power requirements.

\section{EMS Benefits to Agency Mission}

Although methods of execution vary from site-to-site and contractor-to-contractor, implementation of an EMS provides a clear and recognized structure to standardize the evaluation of, preparation for, and execution of activities and projects that have environmental implications. More specific instances in which an EMS can benefit DOE's mission are below.

- $\quad$ Policy development and program planning facilitate integration of environmental compliance programs.

- $\quad$ Promotion of environmental stewardship throughout the project planning cycle (cradle-to-grave).

- $\quad$ Solid waste offsite contract evaluation to ensure that best management practices and appropriate stewardship protocols are built into contracts.

- Enabling a clear and consistent flow down of expectations and compliance framework in contracting documents.

- $\quad$ Clear articulation of DOE complex-wide EMS requirements to promote consistency in contract specifications and environmental management expectations. 
This page intentionally left blank. 


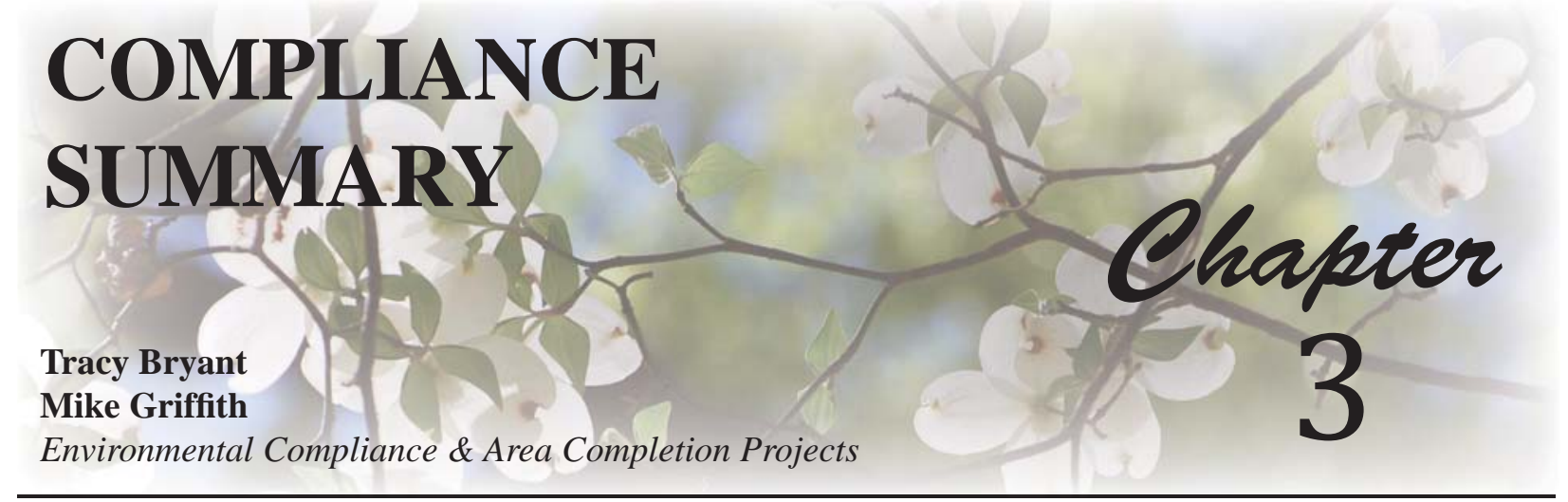

To ensure the protection of human health and the environment through safe operations, the Savannah River Site 1 (SRS) implements compliance programs designed to fulfill requirements of applicable federal, state, and local environmental laws and regulations, and with United States Department of Energy (DOE) orders, notices, directives, policies, and guidance.

The purpose of this chapter is to report the status of SRS compliance with applicable statutes, orders, directives, and programmatic documents. The chapter addresses the following topics:

- Compliance Status,

- SRS Environmental Issues/Actions,

- Continuous Release Reporting,

- Unplanned Releases, and

- Permits.

Table 3-1 summarizes the key federal environmental regulations referenced throughout this chapter.

\section{Compliance Status}

This section addresses environmental restoration, waste management, radiation protection, air quality and protection; water quality and protection, and compliance with other environmental requirements.

SRS's exceptional compliance record demonstrates our commitment to protect the environment. During 2012, SRS environmental staff successfully managed more than 500 environmental permits, each containing numerous compliance requirements and conditions. SRS received one Notice of Violation (NOV) from the South Carolina Department of Health and Environmental Control (SCDHEC) on September 13, 2012, for copper exceedances at National Pollutant Discharge Elimination System (NPDES) H-12 outfall. SRS voluntarily implemented extensive corrective actions to address the violation, and SCDHEC did not access any penalties. SRS received no Notice of Alleged Violations (NOAVs) and continued to meet all regulatory requirements and deadlines. NOVs/NOAVs are the formal regulatory notices that allege violations of an organization's permits or of environmental laws or regulations. SRS continues to evaluate and improve its compliance program to minimize environmental occurrences.

No releases occurred in 2012 that required reporting to local emergency planning committees. 
Table 3-1 Key Federal Environmental Laws and Regulations Applicable to SRS

\begin{tabular}{|c|c|}
\hline Legislation & Requirements \\
\hline $\begin{array}{l}\text { AEA } \\
\text { Atomic Energy Act of 1954, } \\
42 \text { U.S.C. } § 2011 \text { et seq., (1954) }\end{array}$ & $\begin{array}{l}\text { The AEA grants authority to DOE to develop applicable stan- } \\
\text { dards (documented in DOE orders) for protecting the public and } \\
\text { environment from radioactive materials. DOE Order } 435.1 \text { and } \\
\text { implementing Manual 435,1-1, "Radioactive Waste Manage- } \\
\text { ment," provides requirements for radioactive waste management, } \\
\text { waste characterization, storage, treatment, disposal, and closure. }\end{array}$ \\
\hline $\begin{array}{l}\text { CAA } \\
\text { Clean Air Act (1970) }\end{array}$ & $\begin{array}{l}\text { The establishment of air quality standards for criteria pollutants, } \\
\text { such as sulfur dioxide and particulate matter, and for hazardous } \\
\text { air emissions, such as radionuclides and benzene. }\end{array}$ \\
\hline $\begin{array}{l}\text { CAAA } \\
\text { Clean Air Act Amendments of } 1990\end{array}$ & $\begin{array}{l}\text { The establishment of a national permit program, and for provi- } \\
\text { sions that address acid rain, ozone depletion, and toxic air pol- } \\
\text { lution. }\end{array}$ \\
\hline $\begin{array}{l}\text { CERCLA: SARA } \\
\text { Comprehensive Environmental Response, Com- } \\
\text { pensation, and Liability Act (1980); Superfund } \\
\text { Amendments and Reauthorization Act (1986) }\end{array}$ & $\begin{array}{l}\text { The establishment of liability, compensation, cleanup, and emer- } \\
\text { gency response for hazardous substances released to the envi- } \\
\text { ronment. The Federal Facility Agreement (FFA) (89-05-FF) } \\
\text { between the United States Environmental Protection Agency } \\
\text { (EPA), DOE, and SCDHEC integrates CERCLA and Resource } \\
\text { Conservation and Recovery Act (RCRA) requirements to } \\
\text { achieve a comprehensive remediation of SRS. The FFA governs } \\
\text { the corrective/remedial action process, sets annual work priori- } \\
\text { ties, and establishes milestones for activities, including closure } \\
\text { of the high-level waste tanks. The agreement also coordinates } \\
\text { administrative and public participation requirements. }\end{array}$ \\
\hline $\begin{array}{l}\text { CWA } \\
\text { Clean Water Act (1972) }\end{array}$ & $\begin{array}{l}\text { The regulation of liquid discharges at outfalls (e.g., drains or } \\
\text { pipes) that carry effluent to streams (NPDES, Section 402); regu- } \\
\text { lation of dredge and fill operations of U.S. waters (Section 404) } \\
\text { and associated water quality for those activities (Water Quality } \\
\text { Criteria [WQC], Section 401). }\end{array}$ \\
\hline $\begin{array}{l}\text { EPCRA } \\
\text { Emergency Planning and Community } \\
\text { Right-to-Know Act (1986) }\end{array}$ & $\begin{array}{l}\text { The reporting of SRS hazardous substances and their releases to } \\
\text { EPA, state emergency response commissions, and local planning } \\
\text { units. }\end{array}$ \\
\hline $\begin{array}{l}\text { ESA } \\
\text { Endangered Species Act (1973) }\end{array}$ & Prevention of extinction for threatened and endangered species. \\
\hline $\begin{array}{l}\text { FFCA } \\
\text { Federal Facility Compliance Act (1992) }\end{array}$ & $\begin{array}{l}\text { Federal agencies must comply with all substantive and procedur- } \\
\text { al requirements of federal, state, and local solid/hazardous waste } \\
\text { laws in the same manner as any private party. The FFCA requires } \\
\text { DOE to have a Site Treatment Plan (STP) for the development of } \\
\text { treatment capacities and technologies for all of the mixed wastes } \\
\text { at SRS and a Consent Order requiring compliance with such } \\
\text { plan. The Act also requires EPA and authorized states to conduct } \\
\text { annual RCRA inspections of all federal facilities. }\end{array}$ \\
\hline $\begin{array}{l}\text { FIFRA } \\
\text { Federal Insecticide, Fungicide, and Rodenticide } \\
\text { Act (1947) }\end{array}$ & $\begin{array}{l}\text { The regulation of restricted-use pesticides through a state-admin- } \\
\text { istered certification program. }\end{array}$ \\
\hline
\end{tabular}


Table 3-1 Key Federal Environmental Laws and Regulations Applicable to SRS (Continued)

\begin{tabular}{|c|c|}
\hline Legislation & Requirements \\
\hline $\begin{array}{l}\text { MBTA } \\
\text { Migratory Bird Treat Act (1918) }\end{array}$ & The protection of migratory birds, including their eggs and nests. \\
\hline $\begin{array}{l}\text { NDAA } \\
\text { Ronald W. Reagan National Defense Authoriza- } \\
\text { tion Act for Fiscal Year 2005, Section 3116(a), } \\
\text { Pub. Law 108-375, (2005) }\end{array}$ & $\begin{array}{l}\text { Section 3116(a) allows the Secretary of Energy, in consultation } \\
\text { with the Nuclear Regulatory Commission (NRC), to determine } \\
\text { that certain waste from reprocessing is not high-level radioactive } \\
\text { waste requiring deep geologic disposal if it meets the criteria set } \\
\text { forth in Section 3116. Section 3116(b) regards monitoring from } \\
\text { NRC and SCDHEC. }\end{array}$ \\
\hline $\begin{array}{l}\text { NEPA } \\
\text { National Environmental Policy Act (1969) }\end{array}$ & $\begin{array}{l}\text { The identification of potential environmental consequences by } \\
\text { proposed federal activities and potential alternatives to support } \\
\text { informed, environmentally sound decision-making regarding de- } \\
\text { sign and implementation. }\end{array}$ \\
\hline $\begin{array}{l}\text { NHPA } \\
\text { National Historic Preservation Act (1966) }\end{array}$ & The preservation of historical and archaeological sites. \\
\hline $\begin{array}{l}\text { RCRA } \\
\text { Resource Conservation and Recovery Act } \\
\text { (1976) amended by Hazardous and Solid Waste } \\
\text { Amendments (1984) }\end{array}$ & $\begin{array}{l}\text { The management of hazardous and non-hazardous solid waste } \\
\text { and underground storage tanks (USTs) containing hazardous ma- } \\
\text { terials and wastes. Mandates cradle-to-grave requirements for } \\
\text { storage, treatment, and disposal of hazardous waste and investi- } \\
\text { gation and the remediation of inactive waste sites. }\end{array}$ \\
\hline $\begin{array}{l}\text { RHA } \\
\text { Rivers and Harbors Act of } 1899 \text {, Section } 10\end{array}$ & $\begin{array}{l}\text { The regulation of construction over or obstruction of navigable } \\
\text { waters of the United States. }\end{array}$ \\
\hline $\begin{array}{l}\text { SDWA } \\
\text { Safe Drinking Water Act (1974) }\end{array}$ & $\begin{array}{l}\text { The protection of drinking water and public drinking water re- } \\
\text { sources. }\end{array}$ \\
\hline $\begin{array}{l}\text { TSCA } \\
\text { Toxic Substances Control Act (1976) }\end{array}$ & $\begin{array}{l}\text { The regulation of polychlorinated biphenyls (PCBs), radon, as- } \\
\text { bestos, and lead, as well as the evaluation and notification of EPA } \\
\text { of new chemicals and significant new uses of existing chemicals. }\end{array}$ \\
\hline
\end{tabular}

\section{Environmental Restoration and Waste Management}

\section{Environmental Restoration/Cleanup}

SRS is included on the National Priority List (NPL) due to past releases or threatened releases of hazardous substances, pollutants, or contaminants. As such, SRS must assess the nature and extent of the public health and environmental risks associated with the releases, and must determine the appropriate remedial actions required, if any, in accordance with CERCLA, as amended by SARA. DOE, EPA, and SCDHEC, in accordance with Section 120 of CERCLA, entered into the FFA on August 16, 1993. The FFA directs the comprehensive environmental remediation of SRS and integrates CERCLA and RCRA requirements to achieve a comprehensive remediation of SRS and to coordinate administrative and public participation requirements. The FFA governs the remedial action process, sets annual work priorities, and establishes milestones for activities.

SRS has 515 waste units subject to the FFA, including RCRA/CERCLA units, Site Evaluation Areas, and facilities covered as required by the SRS RCRA permit. At the beginning of Fiscal Year (FY) 2012, surface and groundwater cleanup of 373 of these units were complete, and 13 units were in the remediation phase. By the end of FY 2012, 399 units were complete, and 12 units were in the remediation phase. A listing of all 515 waste units at SRS is found in Appendices C ("RCRA/CERCLA Units List") and G ("Site Evaluation List”) of the FFA at http://www.srs.gov/general/programs/soil/ffa/ffa.pdf. The status of FFA activities for FY 2012 can be found at http://www.srs.gov/general/ programs/soil/ffa/ffaapr.pdf. 


\section{Radioactive Liquid Waste Processing and Disposition}

The SRS radioactive liquid waste processing and disposition program completed a successful compliance year in 2012 with no NOVs or NOAVs and continued to meet all regulatory requirements and deadlines. More information can be obtained by viewing the Liquid Waste Disposition page at http://www.Srs.gov/general/programs/liquidwaste/index.htm and the Waste Solidification page at http://www.srs.gov/general/programs/solidification/index.htm on SRS's website.

The Actinide Removal Process (ARP), Modular Caustic Side Solvent Extraction Unit (MCU), and Saltstone Production Facility (SPF) are permitted under the SCDHEC Industrial Wastewater Regulations. The ARP/MCU process will eventually be replaced by the Salt Waste Processing Facility (SWPF), which is currently under construction. The Saltstone Disposal Facility (SDF) is permitted under the SCDHEC Solid Waste Landfill Regulations. New circular Saltstone Disposal Units (SDU) were designed, constructed, watertight tested, and began disposal operations in 2012. SRS designed a new mega SDU (MSDU) and plans to begin construction in 2013. The MDSU is similar to the current circular SDUs but will be much larger and will hold ten times the volume of waste. In 2012, a total of 1.25 million gallons of waste was processed and disposed through the Saltstone facilities.

The Defense Waste Processing Facility (DWPF) is permitted under SCDHEC Industrial Wastewater Regulations. In FY 2012, DWPF produced 275 canisters with approximately one million gallons of glass, immobilizing approximately 7.7 million curies of radioactivity. Since operations began in March 1996, approximately 14 million pounds of glass have been produced and 48 million curies have been immobilized.

The Effluent Treatment Project (ETP) is permitted under the SCDHEC Industrial Water Regulations and processes approximately 20 million gallons of wastewater per year that is monitored and discharged to a state permitted outfall. The Liquid Waste Disposition page on SRS’s website at http://www.srs.gov/general/programs/liquidwaste/index.htm provides additional information.

\section{Radioactive Liquid Waste Tank Closure}

The F- and H-Area Tank Farms are permitted under the SCDHEC Industrial Wastewater Regulations through the provisions of Section IX, "High-Level Radioactive Waste Tank System(s)," of the FFA, and the SCDHEC Industrial Wastewater Treatment Facility Construction Program. In addition, tank closure activities are subject to DOE Order 435.1, "Radioactive Waste Management,” and NDAA, Section 3116 discussed later is this chapter.

Stabilizing the tanks with grout completes operational closure and significantly reduces future risk to the environment, the public, and the SRS workforce. Operational closure activities can only begin after waste in the tanks have been processed/treated and dispositioned in SDUs or DWPF. SCDHEC and EPA oversee the closure process through the protocols DOE has established in the Industrial Wastewater General Closure Plan for both the F- and H-Area Tank Farms. The DOE, SCDHEC, and EPA work closely together to establish strict closure requirements. In addition, Appendix $\mathrm{L}$ of the FFA provides the closure commitments for removing the tanks from service.

The FFA required the operational closure of Tanks 18F and 19F by December 2012. Successful closure of these tanks signifies the most substantial environmental risk reduction achievement for the State of South Carolina since 1997, when SRS closed the first two waste tanks in the nation. Tanks 18F and 19F, each with a waste capacity of approximately 1.3 million gallons, were both constructed in 1958. Both tanks underwent an extensive waste removal process that included bulk waste removal, specialized mechanical cleaning, and isolation of the tanks from all external systems. These activities culminated in regulatory confirmation that the tanks were ready for stabilization. SRS operationally closed Tanks 18F and 19F in September 2012 following a summer when 2,080 cement trucks delivered and poured more than 3.3 million gallons of specially formulated cement-like grout into the tanks. SRS completed this milestone three months ahead of the required operational closure date.

SRS has scheduled Tanks 5F and 6F for operational closure in 2013. The Radioactive Liquid Waste Operational Closure of Tanks fact sheet on SRS's website at http://www.srs.gov/general/news/factsheets/lnwtc.pdf provides additional information. 


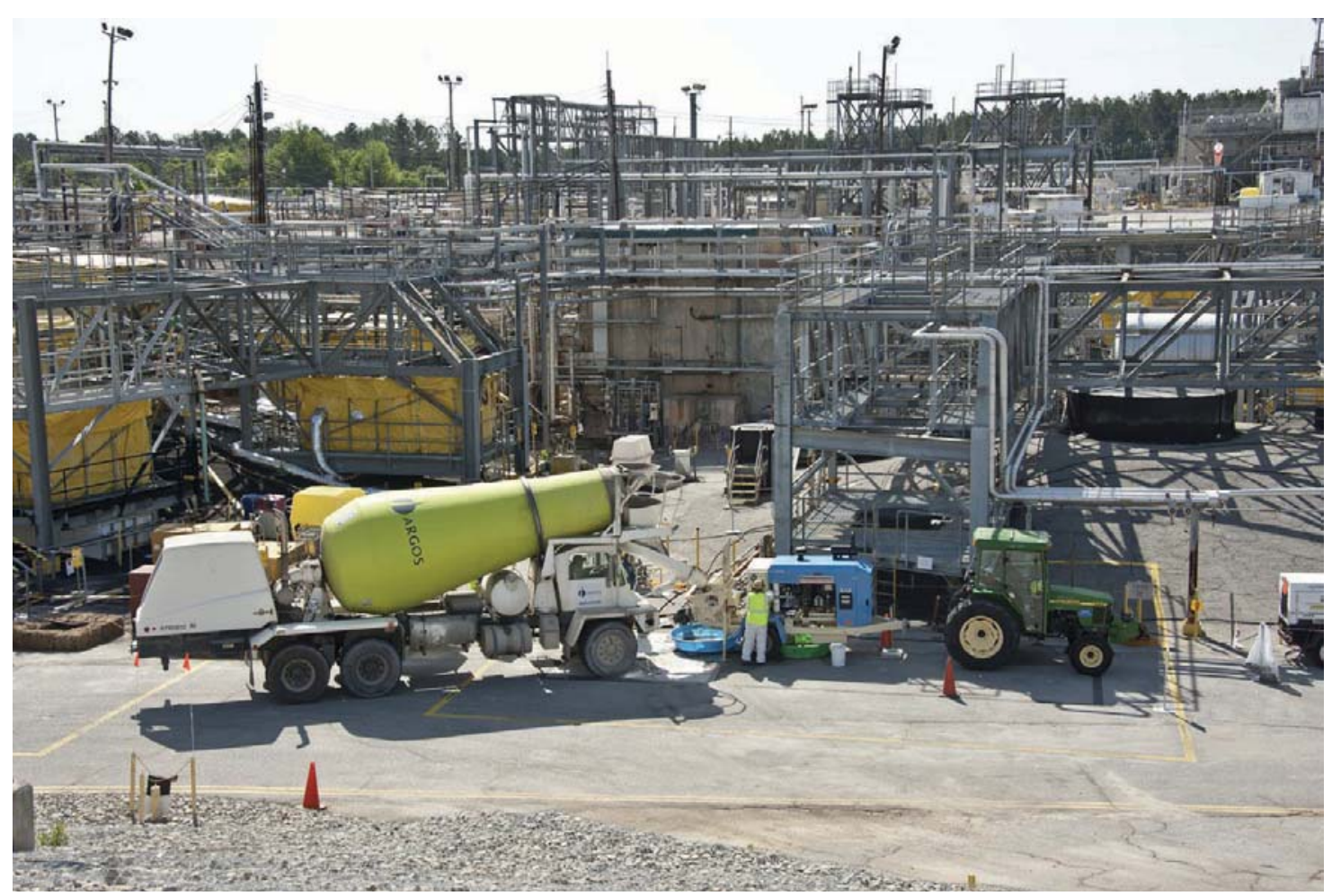

Figure 3-1 SRS Workers Pump Grout from a Concrete Mix Truck to Tank 18F.

\section{Atomic Energy Act/DOE Order 435.1, Radioactive Waste Management}

The Atomic Energy Act of 1954 provides authority to DOE to implement DOE Order 435.1 to ensure radioactive waste is managed in a manner that is protective of worker and public health, and safety, and the environment. SRS manages low-level, high-level, and transuranic (TRU) waste in compliance with DOE Order 435.1 using a number of storage and disposal units. As required by Manual 435.1-1, "Radioactive Waste Management," DOE is required to perform risk informed assessments to evaluate the potential impacts of low-level radioactive waste disposal to the workers, the public, and the environment. The risk-informed assessments are called Performance Assessments (PAs). The PAs provide the technical basis and evaluation needed to demonstrate compliance with DOE Order 435.1. DOE approved site-specific PAs for the E-Area Low Level Waste Facility, SDF, and the F-Area Tank Farm. A site-specific PA for the H-Area Tank Farm is currently under review.

SRS performs a comprehensive annual review to ensure operations and any developing information do not alter the original conclusions of the PAs and that there is a reasonable expectation the facility will continue to meet the performance objectives of the Order. The 2012 annual reviews for the E-Area Low-Level Waste Facility PA and the SDF PA showed that operations in FY 2012 were within the performance envelope, and continued to protect the public and environment.

\section{Ronald W. Reagan National Defense Authorization Act for Fiscal Year 2005, Section 3116}

NDAA Section 3116(a) allows the Secretary of Energy, in consultation with the NRC, to determine that certain waste from reprocessing is not high-level radioactive waste requiring deep geologic disposal, if it meets the criteria set forth in Section 3116(a). The "Basis for Section 3116 Determination for Closure of F-Tank Farm at the Savannah River Site" demonstrated compliance with the Section 3116(a) requirements and provided the basis for the Secretary of Energy's determination on the residual waste in the tanks. After completion of the consultation process with the NRC, the Secretary of Energy signed the Section 3116 Determination for Closure of the F-Tank Farm (DOE-WD-2012-001 http://sro.srs.gov/LW\%20Documents/DOE-WD-2012-001.pdf) in March 2012, in which the Secretary made the de- 
termination, among others that the stabilized residual, tanks, and ancillary structures at closure of the FTF will not require permanent isolation in a deep geologic repository; would have had highly radioactive residuals removed to the maximum extent practical; and would be disposed pursuant to Closure Plans approved by the State of South Carolina.

In 2006, after completing consultation with the NRC, the Secretary of Energy signed the Section 3116 Determination for Salt Waste Disposal at the Savannah River Site. The determination states that treated salt waste meets all of the criteria in NDAA Section 3116(a) and therefore is not high-level waste and may be disposed in SDF. The SDF is currently in the monitoring phase as required by NDAA Section 3116(b). During the monitoring phase the NRC, in coordination with the State of South Carolina, monitors disposal actions taken by DOE for the purpose of assessing compliance with the performance objectives set out in Title 10 Code of Federal Regulations (CFR) Part 61, Subpart C, "Performance Objectives." The NRC publishes the NRC Periodic Compliance Monitoring Report for U.S. Department of Energy Non-High-Level Waste Disposal Actions to document NRC monitoring activities during each calendar year. These reports are available to the public on the NRC web page at http://www.nrc.gov/reading-rm/doccollections/nuregs/staff/sr1911/.

\section{Resource Conservation and Recovery Act (RCRA)}

RCRA established regulatory standards for generation, transportation, storage, treatment, and disposal of hazardous waste. EPA authorizes SCDHEC to regulate hazardous waste and the hazardous components of mixed waste at SRS. Mixed waste contains both radioactive and hazardous components. A RCRA hazardous waste permit application contains two parts - Part A and Part B. Part A consists of the required EPA forms along with general facility information including maps, drawings, and photographs. Part B of the RCRA hazardous waste permit application contains detailed, site-specific information addressing the treatment, storage, and disposal facilities operated and closed by SRS. SRS currently has one RCRA Part A permit volume and 13 Part B permit volumes. SRS operated and maintained closed treatment, storage, and disposal facilities in compliance with the SRS RCRA permit requirements in 2012.

Nineteen USTs at SRS contain petroleum products and are regulated under Subtitle I of RCRA. These tanks require an annual compliance certificate from SCDHEC. The SCDHEC inspection and audit on October 23, 2012 found all 19 tanks to be in compliance, marking ten consecutive years without a violation.

\section{Federal Facility Compliance Act (FFCA)}

The AEA, as administered through DOE orders, regulates radioactive wastes and the radioactive component of mixed wastes. The FFCA requires the identification of existing quantities for mixed waste, the proposal of methods and technologies of treatment and management, the creation of enforceable timetables, and the tracking and completion of deadlines. In 1995, SRS obtained approval of a Site Treatment Plan (STP) as required by the FFCA. As part of compliance activities associated with the Consent Order, SRS and SCDHEC meet annually to discuss the status of the STP and determine if the agreed-upon five-year interval is appropriate or if more frequent intervals are necessary. SRS and SCDHEC held the annual STP status meeting in June 2012. The parties examined and discussed current milestones and projected status of the STP goals. Neither party identified concerns during the meeting that would warrant submittal of a 2012 STP update. SRS will schedule the next annual STP status meeting in 2013.

\section{Toxic Substances Control Act (TSCA)}

SRS has a well-structured program that complies with TSCA regulations, with DOE orders, and with Site policies regarding the use, storage, and disposal of organic chemicals (polychlorinated biphenyl (PCB)). SRS disposes of routinely generated non-radioactive PCBs at EPA-approved facilities within the regulatory period, which is one year from the date of generation. SRS completed the 2011 PCB document log and submitted the 2011 annual report of onsite PCB disposal activities to EPA in July 2012, meeting applicable requirements.

Disposal capacity is not immediately available for some forms of radioactive PCB wastes, specifically those contaminated TRU radionuclides. Such wastes will remain in long-term storage pending necessary processing and packaging that will allow shipment for disposal to the Waste Isolation Pilot Plant (WIPP) in New Mexico. SRS stores these wastes in TSCA-compliant storage facilities. SRS did not ship any PCB/TRU waste in 2012. 
In April 2012, EPA visited the Dynamic Underground Stripping (DUS) project located in M Area in advance of the formal request from SRS to modify the existing TSCA risk-based disposal approval. The renewal revisions included changing the name of the treatment system to Western Sector Treatment System (WSTS) to reflect current activities, reuse of certain containers without decontamination, and expanding the use of RCRA land disposal restriction debris technology for some system components that will be removed during dismantlement of some of the existing DUS system. SRS received approval of the application for risk-based disposal for WSTS in November 2012.

\section{Infectious Waste}

To comply with South Carolina Infectious Waste Management Regulation, R.61-105, SRS contracts with a vendor for monthly pick-up and destruction of infectious (medical) waste. In 2012, SRS managed all infectious wastes in compliance with the requirements for treatment, storage, transportation, and disposal or destruction. SCDHEC registers SRS as a large quantity generator based on the amount of infectious waste generated per month. The current SRS Infectious Waste Generator Registration expires on April 30, 2014.

\section{Radiation Protection}

\section{DOE Order 458.1, Radiation Protection of the Public and the Environment}

DOE Order 458.1, "Radiation Protection of the Public and the Environment," establishes the requirements for protection of the public and the environment against any undue risk from radiation associated with radiological activities at DOE sites. SRS completed implementation of this Order during 2012 which requires an Environmental Radiological Protection Program (ERPP). The SRS ERPP is a composite of plans, procedures, and other documents that describe the methods used to ensure SRS implements the appropriate actions for complying with the requirements of DOE Order 458.1.

DOE Order 458.1 specifies radiation dose standards for individual members of the public. The dose standard to the general public is 100 millirem (mrem) (1 millisievert [mSv]) per year to a person from routine DOE operations. In 2012, the representative person was 0.26 mrem, which is less than $1 \%$ of the 100 mrem standard and consistent with estimated doses to the public from previous years. Chapter 6, "Radiological Dose Assessments," provides additional information on the process for determining radiological dose to the public.

\section{Air Quality and Protection}

\section{Clean Air Act (CAA)}

Though EPA maintains overall authority for the control of nonradiological air pollution under the CAA, EPA has delegated regulatory authority for all types of emissions to SCDHEC. SCDHEC's air pollution regulations are at least as stringent as the federal requirements. SRS is required to comply with SCDHEC Regulation 61-62, "Air Pollution Control Regulations and Standards.” The various CAA programs covered by these SCDHEC regulations are discussed below.

\section{Title V Operating Permit Program}

SCDHEC classifies SRS as a "major source" of nonradiological air emissions, and SRS falls under the CAA Part 70 Operating Permit Program. The Part 70 Air Quality Permit regulates radioactive, nonradioactive, toxic, and criteria pollutant emissions from 19 emission units, with each unit having specific emission limits, operating conditions, and monitoring and reporting requirements. The operating permit also contains an "Insignificant Activities List," that identifies approximately 500 SRS sources that are exempt from monitoring based on insignificant emission levels, or on equipment size or type. The current SRS Title V operating permit expired on June 20, 2012. SRS submitted a renewal application and expects to receive the new Part 70 Air Permit from SCDHEC in 2013. Until the permit is renewed, SRS continues to operate in accordance with requirements of the current permit. 
DOE proposed replacement of the existing D-Area Powerhouse prior to the expiration of its Title V operating permit. Construction and start-up of the biomass cogeneration facility under the SCDHEC Construction Permit No. 00800144CA (November 12, 2008) required permanent removal of the existing coal-fired boilers at the D-Area Powerhouse from operation. SRS completed construction and start-up of the new plant in 2012. After more than 60 years of operation, SRS removed the D-Area Powerhouse from service prior to expiration of the Title V Operating Permit. On May 15, 2012, SCDHEC cancelled the Title V Permit for the D-Area Powerhouse.

SCDHEC issued an air construction permit (08800139CA) for the Mixed Oxide Fuel Fabrication Facility (MFFF), a part of the SRS Nuclear Nonproliferation Program. Construction of the MFFF began August 1, 2007 and continued through 2012.

SCDHEC evaluated compliance with the SRS Part 70 Air Quality Permit conditions on March 6, 2012. The inspection report issued by SCDHEC concluded that no violations of permit requirements or applicable regulations were observed during this evaluation.

\section{Accidental Release Prevention Program}

As outlined in the Clean Air Act Amendments of 1990 Section 112(r), any facility that maintains specific hazardous or extremely hazardous chemicals in quantities above specified threshold values must develop a risk management plan (RMP). The RMP develops hazard assessments in the event of an accidental release, completes prevention and training programs, and establishes emergency response programs should a release occur. In 2012, SRS maintained hazardous and extremely hazardous chemical inventories below the threshold value; therefore, SRS was not required to develop an RMP. No reportable 112(r)-related hazardous or extremely hazardous chemical releases occurred at SRS in 2012.

\section{Ozone-Depleting Substances}

The CAA mandates air quality standards for the protection of stratospheric ozone. The CAA Title V Operating Permit Program requires SRS to comply with the standards for emissions reduction and phase-out pursuant to 40 CFR 82. The permit specifies compliance with the requirements of Subpart B ("Servicing of Motor Vehicle Air Conditioners”), Subpart E ("The Labeling of Products using Ozone-Depleting Substances”), and Subpart G ("Significant New Alternatives Policy Program”). Accordingly, all leak repair data for large (greater than or equal to 50-pound charge) heating, ventilation, and air conditioning/chiller systems are reported monthly. Incidental discharges from refrigerant sources at SRS during 2012 totaled 11,119 pounds. In 2012, SRS did not experience any releases of refrigerant during recycle and recovery activities in excess of acceptable amounts allowed by the regulation.

The Title V operating permit also requires that SRS not knowingly or willfully release ozone-depleting substances (ODS) such as halon into the atmosphere (40 CFR 82, Subpart H, "Halon Emissions Reduction"). SRS uses haloncontaining equipment as a fire suppression agent in some facilities. The SRS Fire Department (SRSFD) maintains and recharges halon-containing equipment, and manages the national halon repository (Savannah River Halon Repository). The SRSFD reports the total halon inventory in an annual report to DOE. As of December 31, 2012, there were approximately 52,114 pounds in the SRS inventory, including 19,704 pounds in 85 installed fire suppression systems, and 7,075 pounds of unprocessed halon stored in original containers. The balance, 25,365 pounds, has been processed and is stored onsite in 1-ton bulk containers. In addition to the SRS inventory, SRS maintains 31,690 pounds on halon in the national halon repository. In 2012, SRS did not experience any releases of halon during recycle and recovery activities in excess of acceptable amounts allowed by regulation.

\section{Air Emissions Inventory}

SCDHEC Regulation 61-62.1, Section III (“Emissions Inventory”), requires compilation of an air emissions inventory in order to locate all sources of air pollution and to define and characterize the various types and amounts of pollutants. To demonstrate compliance, SRS personnel conducted the initial comprehensive inventory of air emissions sources. SRS used source operating data and calculated emissions from 1990 to establish the baseline emissions and to provide data for air dispersion modeling. 
SRS is required to submit an annual air emission inventory report to SCDHEC by March 30 for the previous calendar year. SRS submitted the 2011 emissions inventories on March 29, 2012 for Operation Permit 0080-0041. EPA created the National Emissions Inventory as a comprehensive and detailed estimate of air emissions of both criteria and hazardous air pollutants from all air emissions sources, including SRS. The EPA website at http://www.epa.gov/ttn/chief/eiinformation.html provides the most recent information.

\section{National Emission Standard for Hazardous Air Pollutants (NESHAP)}

NESHAP is a CAA-implementing program that sets air quality standards for hazardous air pollutants, such as radionuclides, benzene, and asbestos.

\section{NESHAP Radionuclide Program}

The current list of 187 hazardous air pollutants includes all radionuclides as a single pollutant. EPA has delegated regulation of these pollutants to SCDHEC; however, EPA continues to oversee some aspects of the regulation.

SRS maintains compliance with the NESHAP Radionuclide Program by performing all required inspections and maintaining monitoring systems to meet regulatory requirements. Subpart $\mathrm{H}$ of the NESHAP regulations require SRS to determine and report annually by June 30 the highest effective dose to any member of the public at an offsite point. SRS transmitted the "SRS Radionuclide Air Emissions Annual Report for 2012" on June 14, 2012 to EPA, SCDHEC, and DOE Headquarters.

During 2012, the maximally exposed individual effective dose equivalent, calculated using the NESHAP required CAP88 computer code, was estimated to be $3.95 \times 10^{-2}$ millirem (mrem) $/ \mathrm{yr}\left(3.95 \times 10^{-4} \mathrm{mSv} / \mathrm{yr}\right)$, which is $0.4 \%$ of the $10 \mathrm{mrem} / \mathrm{yr}$ (0.10 mSv per year) EPA standard. Chapter 6, "Radiological Dose Assessments," contains details on this calculation.

\section{NESHAP Non-radionuclide Program}

SRS uses many chemicals identified as toxic or hazardous air pollutants, but most of them-due to quantities or usage are not regulated under the CAA or federal NESHAP regulations. Except for asbestos, SRS facilities and operations do not fall into any of the "categories" listed in the original subparts. In December 1993, EPA issued a final list of hazardous air pollutant-emitting source categories potentially subject to maximum achievable control technology (MACT) standards; promulgated MACT standards for source categories have not affected SRS to date.

\section{NESHAP Asbestos Abatement Program}

Site compliance for asbestos operations and maintenance (O\&M) activities, minor and small jobs as well as building renovations and demolitions falls under SCDHEC and federal regulations. SRS conducted 27 permitted renovations and demolitions in 2012.

SCDHEC issued an Asbestos Abatement Group License to SRS (Number ASB-8021). SRS manages O\&M, minor and small-licensed projects through the SRS Asbestos Disturbance Notice (ADN) procedure. In addition to "projectspecific" ADNs, SRS issued ADN notifications to each Site facility on a quarterly basis, which allow SRS to report amounts of Asbestos Containing Material (ACM) removed and disposed of during each quarter. SRS issued 50 ADN notifications in 2012. Certified personnel removed and disposed of 280 linear feet, 129 square feet, and 60 cubic feet of friable (regulated) ACM, and 19 linear feet, 4,290 square feet and 15 cubic feet of non-friable (unregulated) ACM during 2012. The 2012 SRS Annual Asbestos Group License report listed 288 asbestos specialist certified by SCDHEC in the Project Designer, Building Inspector, Supervisor, Worker, and O\&M Worker disciplines.

SRS disposed of 148 linear feet, 2,493 square feet, and four cubic feet of radiologically contaminated asbestos waste in 2012 at the SRS E-Area Low-Level Waste Facility. Nonradiological asbestos waste was disposed of at the Three Rivers Solid Waste Authority Landfill. Both disposal sites are SCDHEC-approved landfills for the disposal of regulated and non-regulated ACM. 


\section{Water Quality and Protection}

\section{Clean Water Act (CWA)}

\section{National Pollutant Discharge Elimination System (NPDES)}

SCDHEC administers the NPDES program under EPA authority. The program protects surface waters by limiting releases of effluents into streams, reservoirs, and wetlands.

SRS had five NPDES permits in 2012:

- Two permits for industrial wastewater discharges (SC0047431, for the D-Area Powerhouse and SC0000175, for the remainder of SRS);

- Two general permits for stormwater discharges (SCR000000 for industrial and SCR100000 for construction); and

- One general utility water permit SC250273, issued May 5, 2011.

Throughout the year, SRS monitors 28 NPDES-permitted industrial wastewater outfalls across SRS on a monthly basis. For each outfall, physical, chemical, and biological parameters are determined and reported to SCDHEC in SRS monthly discharge monitoring reports, as required by the permit. Annually, SRS reports more than 1,400 measurements. In 2012, the SRS NPDES program maintained a greater than 99\% compliance rate. SRS had six permit limit exceptions during 2012, and received one NOV for an exceedance of copper limits at H-12 outfall. Table 3-2 summarizes the NPDES exceptions.

SRS has one no-discharge permit for land application of biosolids (ND0072125). This permit was renewed in 2010 and is applicable for 10 years. Chapter 4, "Effluent Monitoring," provides additional information about SRS's NPDES permits.

Table 3-2 Summary of SRS-NPDES Limit Exceptions in 2012

\begin{tabular}{|c|c|c|l|}
\hline Outfall & Parameter & $\begin{array}{c}\text { Number of } \\
\text { Exceptions }\end{array}$ & \multicolumn{1}{|c|}{ Description/Solution } \\
\hline L-07A & Flow & 1 & $\begin{array}{l}\text { Debris blocked drainage channel, which reduced flow. } \\
\text { The channel was cleared of debris. }\end{array}$ \\
\hline $\mathbf{H - 1 2}$ & $\begin{array}{c}\text { Copper - Average } \\
\text { Concentration }\end{array}$ & 2 & $\begin{array}{l}\text { Increased chlorination of cooling water was necessary } \\
\text { due to higher ambient water temperature. Copper leached } \\
\text { from pipes due to elevated chlorine concentration. SRS } \\
\text { submitted a corrective action plan to SCDHEC. }\end{array}$ \\
\hline L-07 & $\begin{array}{c}\text { Copper - Maximum } \\
\text { Concentration }\end{array}$ & 1 & $\begin{array}{l}\text { Increased chlorination of cooling water was necessary } \\
\text { due to higher ambient water temperature. Copper leached } \\
\text { from pipes due to elevated chlorine concentration. SRS } \\
\text { submitted a corrective action plan to SCDHEC. }\end{array}$ \\
\hline $\mathbf{H - 0 2}$ & $\begin{array}{c}\text { Zinc - Maximum } \\
\text { Concentration }\end{array}$ & 1 & $\begin{array}{l}\text { Low-pH river water lowered outfall pH. Outfall pH can- } \\
\text { not be adjusted. }\end{array}$ \\
\hline
\end{tabular}

The NPDES General Permit for Stormwater Discharges (SCR000000) associated with industrial activity requires installing, implementing, and maintaining control measures to ensure that stormwater discharges do not result in an exceedance of water quality standards in receiving streams. One outfall exceeded benchmark levels and required 
installation of additional control measures; however, no violations of this permit occurred in 2012. Results from sampling of stormwater outfalls appear in effluent monitoring Data Table 4-9 in the "Environmental Data/Maps - 2012" section of the CD accompanying this report.

SCDHEC issued an industrial wastewater discharge (Permit No. SC0049107, G-05 outfall) to Ameresco for discharges associated with the Biomass Cogeneration Facility. This permit is independent of SRS's permits.

\section{Dredge and Fill; Rivers and Harbors}

In 2012, SRS had four open permits under the Nationwide Permits (NWPs) program (general permits under Section 404) and the RHA, Section 10, as follows:

- SRS completed dam construction on an unnamed tributary to Fourmile Branch for the Mixed Waste Management Facility Groundwater Interim Measures project in 2000 under NWP 38, "Hazardous Waste Cleanup.” However, mitigation for the impact to wetlands was pending in 2012 and must be addressed before the permit can be closed. DOE is evaluating a request to use wetland mitigation bank credits to satisfy the mitigation issue and close the permit.

- SRS initiated a project during 2009 to dredge sediments out of the 681-3G and 681-5G pump house canals to allow for better flow to the water intake of each pump house. The U.S. Army Corps of Engineers (USACE) issued a RHA of 1899 Section 10 permit (SAC-2008-1156) on March 24, 2009, to allow the dredging work to begin. SRS successfully dredged both canals and returned them to their original design. Maintenance dredging of accumulated sediments in the 681-5G canal will occur as needed until the permit authorization expires on March 31, 2014. The Section 10 permit will remain open until March 31, 2014.

- $\quad$ SRS installed ten shallow hand-augured wells in wetlands adjacent to Castor Creek for groundwater sampling activities. SRS permitted this activity by rule in April 2012 under NWP 5-Scientific Measurement Devices.

- $\quad$ SRS installed a Ballymore Ladder in Fourmile Creek at Sampling Location 4MC-002F to minimize safety hazards. SRS permitted this activity by rule in December 2012 under NWP 5-Scientific Measurement devices.

\section{Safe Drinking Water Act (SDWA)}

SCDHEC regulates drinking water facilities under the SWDA. SRS uses groundwater sources to supply onsite drinking water facilities. The A-Area and D-Area drinking water facilities supply most Site areas. Remote facilities such as field laboratories, barricades, and pump houses utilize small drinking water systems or bottled water.

SRS and SCDHEC collect and analyze samples to ensure that all Site domestic water systems meet SCDHEC and EPA bacteriological and chemical drinking water quality standards. All samples collected in 2012 met these standards. Refer to Chapter 5, "Environmental Surveillance,” of this report for results.

The SRS domestic water systems are sampled for lead and copper on a three-year cycle. In 2012, the D-Area system was in compliance with the SCDHEC action levels for lead and copper. SRS will sample the A-Area system for lead and copper in 2013.

\section{Other Environmental Requirements}

\section{National Environmental Policy Act (NEPA)}

SRS initiates the evaluation process required by NEPA by completing an Environmental Evaluation Checklist (EEC) for new projects or changes to existing projects. SRS uses the EEC to review the proposed action, identify any potential environmental concerns, and determine the appropriate level of NEPA review required for the project.

SRS conducted 413 NEPA reviews in 2012 (Table 3-3). For additional information on SRS NEPA activities, visit the NEPA webpage at http://www.srs.gov/general/pubs/envbul/nepa1.htm. 
Table 3-3 Summary of SRS-Related NEPA Reviews in 2012

\begin{tabular}{|c|c|}
\hline Type of NEPA Review & Number \\
\hline Categorical Exclusion Determination & 304 \\
\hline “All No” EEC Determinations ${ }^{a}$ & 78 \\
\hline Actions Tiered to Previous NEPA Reviews & 23 \\
\hline Environmental Impact Statements (EIS) ${ }^{\mathrm{b}}$ & 3 \\
\hline Supplement Analysis ${ }^{\mathrm{c}}$ & 3 \\
\hline Interim Action & 1 \\
\hline Revised FONSI & 1 \\
\hline Environmental Assessments (EA) & 0 \\
\hline Total SRS-Related NEPA Reviews & 413 \\
\hline \multicolumn{2}{|c|}{$\begin{array}{l}\text { a Proposed actions that require no further NEPA action } \\
\text { b DOE/EIS-0283-S2, Surplus Plutonium Disposition Supplemental EIS; DOE/EIS-0375, Disposal of } \\
\text { Greater-Than-Class-C Low-Level Radioactive Waster; DOE-EIS/0423, Long-Term Management and } \\
\text { Storage of Elemental Mercury (all in progress) } \\
\text { c SA for SRS Spent Nuclear Fuel Management FEIS DOE/EIS -0279 (in progress) } \\
\text { SA for SRS-High-Level Waste Tank Closure Environmental Impact Statement DOE/EIS-0303-SA-01 } \\
\text { SA for Transportation of Depleted Uranium Hexafluoride for Conversion to Depleted Uranium } \\
\text { Oxide DOE/EIS-0283-SA-03 }\end{array}$} \\
\hline
\end{tabular}

The following is a listing of the major NEPA reviews conducted in 2012, some of which are scheduled for completion in 2013:

- Revised Finding of No Significant Impact (FONSI) for the Environmental Assessment for the Proposed Use of SRS Lands for Military Training (DOE/EA-1606) - In the 2011 EA, DOE defined "Army" as an all-inclusive term for Department of Defense and Department of Homeland Security organizations that use SRS lands and facilities for training purposes. In the revised FONSI, DOE clarified this definition to include work performed by the Savannah River National Laboratory (SRNL) under Work for Others agreements, such as overseeing and facilitating the Federal Bureau of Investigation’s Vehicle Borne Radiological Dispersal Device training. Because the training activities that would be performed under Work for Others agreements are consistent with the type of exercises described in the Army EA, and because it would be conducted in accordance with the Joint Standard Operating Procedures (Appendix A to the Army EA), DOE found that these exercises can be conducted without significant environmental impacts. DOE published the revised FONSI in August 2012.

- Supplement Analysis (SA) for Transportation of Depleted Uranium Hexafluoride (DUF) for Conversion to Depleted Uranium Oxide (DUO) (DOE-EIS-0283-SA-03) - DOE prepared an SA for the proposal to transport cylinders of DUF from the Portsmouth Gaseous Diffusion Plant in Piketon, Ohio to the AREVA-NP Fuel Fabrication Facility in Richland, Washington, and subsequently transport cylinders containing DUO from Richland to SRS. Based on this analysis, DOE's proposed action does not represent substantial changes that are relevant to environmental concerns for DUF-DUO transportation actions evaluated in the Surplus Plutonium Disposition (SPD) EIS. Consequently, because no new concerns are generated, the proposed action will not warrant additional NEPA analysis. DOE previously decided to prepare DUO from DUF to support the MFFF. DOE is not changing that decision; therefore, no revision to the record of decision is required. DOE published the SA in September 2012.

- Interim Action Determination for the Use of H Canyon/HB-Line to Prepare Feed for the Mixed Oxide Fuel Fabrication Facility at the Savannah River Site - DOE, including the National Nuclear Security Administration (NNSA), began preparing the SPD Supplemental Environmental Impact Statement (SEIS) (DOE/EIS-0283-S2). In the SEIS, DOE evaluates alternatives for disposition of plutonium no longer needed to support national security of the United States. The Department continues to evaluate alternative disposition paths for surplus plutonium materials and options for preparing plutonium oxide feed material for MFFF. DOE anticipates issuing the final SPD SEIS in 2013. In the interim, DOE is exploring options for preparing plutonium oxide feed material for the MFFF, with respect to certain plutonium that DOE previously decided to fabricate into mixed oxide (MOX) fuel. DOE has reviewed the environmental analyses relevant to processing alternate feedstock (AFS) metal to oxide in 
H Canyon. Based on these analyses, DOE found that the impacts of processing these materials would be significantly less than the historical levels of operating the $\mathrm{H}$ Canyon facilities. Therefore, no adverse environmental impacts would result from processing AFS material in $\mathrm{H}$ Canyon. In addition, because $\mathrm{H}$ Canyon would not be capable of carrying out the entire mission of producing plutonium metal for MFFF, or even a significant fraction of the mission, use of these facilities in the near-term, prior to selection of an option for plutonium conversion, does not limit the choice of reasonable alternatives being evaluated in the SPD SEIS. Therefore, this action is an allowable interim action in accordance with DOE and Council on Environmental Quality regulations for implementing NEPA. DOE published the interim action determination in July 2012.

\section{Emergency Planning and Community Right-to-Know (EPCRA)/SARA Title III}

EPCRA requires facilities to notify state and local emergency planning entities about their hazardous chemical inventories and to report releases of hazardous chemicals. The Pollution Prevention Act of 1990 expanded the EPCRA-mandated Toxic Chemical Release Inventory (TRI) report to include source reduction and waste management activities. SRS is required to implement the following reporting programs and was in compliance with all reporting requirements respectively in 2012 .

\section{Executive Order 12856}

Executive Order 12856, "Federal Compliance with Right-to-Know Laws and Pollution Prevention Requirements," requires that all federal facilities comply with right-to-know laws and pollution prevention requirements. SRS complies with the appropriate reporting requirements for EPCRA, and incorporates the applicable TRI chemicals into its pollution prevention efforts.

\section{Chemical Inventory Report (Tier II)}

As required by Section 312 of EPCRA, SRS completes an annual Tier II Chemical Inventory Report for all hazardous chemicals present at SRS in excess of specified quantities during the calendar year. SRS submits hazardous chemical storage information to state and local authorities electronically via the Homeland Security E-Plan database by March 1 for the previous calendar year. SRS submitted the Tier II for 2011 on February 22, 2012.

\section{Toxic Release Inventory Report (Form R)}

As required by Section 313 (“Toxic Chemical Release Inventory”) of EPCRA, SRS must file an annual TRI report by July 1 for the previous year. SRS calculates chemical releases to the environment for each regulated chemical and reports those above the threshold value to EPA.

For 2011, SRS submitted a Form R on July 28, 2012 for each of the following regulated chemicals: barium, chlorine, chromium, copper, fluorine, formic acid, hydrochloric acid, led, mercury, nickel nitrate, nitric acid, sodium nitrate, sulfuric acid, xylene, asbestos, and zinc. The EPA website at http://www.epa.gov/tri/tridata provides specific details, including release amounts and detailed information about toxic release inventory reporting.

\section{Federal Insecticide, Fungicide, and Rodenticide Act (FIFRA)}

FIFRA regulates the application of restricted-use pesticides (RUPs) at SRS through a state-administered certification program. At SRS, a licensed pesticide specialist approves and monitors pesticide applications. SRS documents usage which allows environmental personnel to monitor application practices as well as to report total annual chemical inventories or usage to meet EPCRA reporting responsibilities.

The NPDES General Permit for Discharges of Application of Pesticides (PCP) requires tracking of pesticide (i.e., pesticides, herbicides, biocides) applications near water bodies as well as right-of-way treatments of intrusive vegetation. If a treatment reaches the regulatory threshold within any calendar year, the SRS must notify SCDHEC and implement detailed programmatic requirements. SRS did not exceed these thresholds in 2012. 


\section{Endangered Species Act (ESA)}

The ESA provides for the designation and protection of wildlife, fish, and plants in danger of becoming extinct. The Act also protects and conserves the critical habitats on which such species depend.

Several federally endangered plant and animal species exist at SRS, including the wood stork, the red-cockaded woodpecker, the shortnose sturgeon, and pondberry shrub, and the smooth purple coneflower. In addition, found on the SRS is the gopher tortoise, which was recently listed as a candidate for protection as required by the ESA. Although the bald eagle no longer is on the endangered species list, it remains protected as required by the Bald and Golden Eagle Protection Act. Also found at SRS is the Carolina gopher frog, which is a South Carolina endangered amphibian. Programs are in place onsite to enhance the habitat and survival of such species.

During Fiscal Year 2012, while implementing the United States Department of Energy Natural Resources Management Plan for the Savannah River Site (http://www.fs.usda/gov/Internet/FSE DOCUMENTS/stelprdb5208304.pdf), United States Department of Agriculture Forest Service-Savannah River (USFS-SR) personnel developed four biological evaluations for timber and wildlife-related management activities associated with three SRS watersheds, as well as for red-cockaded woodpecker habitat areas in the northern part of SRS. These biological evaluations determined that forest implementation plans are not likely to adversely affect threatened and endangered species due to beneficial, insignificant, or discountable effects. Additionally, USFS-SR reviewed revisions to three SRS watershed management plans and determined complete biological evaluations were not warranted.

\section{National Historic Preservation Act (NHPA)}

The NHPA requires that all federal agencies consider the impacts to historic properties in all their undertakings. SRS ensures compliance with the NHPA through several processes. SRS has implemented The Cold War Programmatic Agreement and “SRS's Cold War Built Environment Cultural Resource Management Plan.” The Savannah River Archaeological Research Program (SRARP) provides cultural resource management guidance to DOE to ensure fulfillment of compliance commitments. SRARP also serves as a primary facility for investigation of archaeological research problems associated with cultural development within the Savannah River valley, using the results to help DOE manage more than 1,900 known archaeological sites at SRS.

The Site Use Program is also used to ensure compliance with NHPA. Through this program, SRARP evaluates all locations being considered for activities, such as construction, to ensure that archaeological or historic sites are not impacted. Reviews of timber compartment prescriptions include surveying for archaeological resources and documenting areas of importance with regard to historic and prehistoric significance.

More information on activities conducted by the SRARP in 2012 can be obtained by visiting the SRARP website at http://www.srarp.org. In addition, SRARP's 2012 report is included on the CD accompanying this report.

\section{Migratory Bird Treaty Act (MBTA)}

The MBTA prohibits the taking, possession, import, export, transport, selling, purchase, or barter of, or offering for sale, purchase or barter, any migratory bird or its eggs, parts, and nests, except as authorized under a valid permit. In 2012, SRS personnel found several nests that required protection by the MTBA in large mobile equipment located at various Site locations. SRS maintained barricades around the equipment until the hatchlings fledged or SRS determined, with concurrence by the U.S. Fish and Wildlife Service, the nests were no longer viable. 


\section{DOE Orders/Executive Orders for Environmental Systems}

\section{Summary of Environmental Management Systems (EMS) Program}

SRS complies with the requirements set forth in DOE Orders 450.1A, "Environmental Protection Program,” and 430.2B, “Department Energy, Renewable Energy and Transportation Management,” to use an EMS as the framework to implement, manage, measure, and continually improve upon sustainable environmental, energy, and transportation practices. Chapter 2, “Environmental Management System,” contains additional information on these and other sustainability programs.

\section{DOE Order 436.1/Greenhouse Gas Reduction}

DOE Order 436.1, “Department Sustainability,” incorporates requirements in Executive Orders 13514, "Federal Leadership in Environmental, Energy, and Economic Performance,” and 13423, "Strengthening Federal Environmental, Energy, and Transportation Management,” and other related statutes, administrative requirements, and goals. Executive Order 13514 established greenhouse gas reduction goals based on estimated emissions in 2008 . Scope 1 and 2 items (power generation facilities) have a 28\% reduction goal, and Scope 3 items (business and employee travel) have a $13 \%$ reduction goal by 2020 .

Reducing energy intensity, completing construction and starting operation of a Biomass Cogeneration Facility, operating satellite biomass plants, and increasing the use of alternative fuels, alternative-fuel vehicles, and hybrid vehicles are some ways SRS made progress toward this goal in 2012. Chapter 2, "Environmental Management System,” provides details on meeting Site sustainability goals.

\section{Waste Minimization and Pollution Prevention Program Results and Highlights}

The SRS Waste Minimization and Pollution Prevention (WMin/P2) Program continued to achieve significant results in 2012. All required Site waste generator organizations demonstrated active participation in the program through documented pollution avoidance and/or direct mission support activities for Site recycling. SRS employees’ P2 awareness was increased through online articles and both general employee and job-specific training.

The WMin/P2 Program met all DOE and regulatory agency reporting requirements. Chapter 2, “Environmental Management System,” highlights 2012 program accomplishments.

\section{Floodplain and Wetlands Management}

As required by 10 CFR 1022, “Compliance with Floodplains and Wetlands Environmental Review Requirements”, DOE establishes policies and procedures for implementing its responsibilities in terms of compliance with Executive Orders 11988, “Floodplain Management,” and 11990, “Protection of Wetlands.” This regulation includes DOE policies regarding the consideration of floodplains and wetlands factors in planning and decision making. It also includes DOE procedures for identifying proposed actions involving floodplains and wetlands, providing early public reviews of such proposed actions, preparing floodplains/wetlands assessments, and issuing statements of findings for actions in floodplains.

A Floodplain and Wetland Assessment was prepared in compliance with 10 CFR 1022 to document potential impacts of time-critical removal action as required by CERCLA selected to manage potential risks along the Lower Three Runs (LTR) tail. The removal action excavation sites are located in the 100-year floodplain of the LTR within Barnwell County and Allendale County, South Carolina. The assessment examined the impacts of the removal action within three discreet locations within the LTR floodplain. The actions included the excavation of contaminated soil in LTR floodplain wetlands, the installation of additional fencing and fence posts along the DOE property lines adjacent to LTR, and the installation of no trespassing sign posts along the DOE property lines adjacent to LTR. DOE approved the final Floodplain and Wetland Assessment in April 2012. 


\section{SRS Environmental Issues/Actions}

\section{Lawsuits}

SRS was not involved in any environmental lawsuits during 2012.

\section{Notice of Violation/Notice of Alleged Violation}

SRS reported six NPDES permit condition exceptions in 2012. On September 11, 2012, SCDHEC notified SRS of a violation of NPDES effluent limits for a group of three copper limit exceptions at H-12 outfall in June and July of 2012. An investigation concluded that the copper leached from cooling system components in the presence of elevated chlorine levels required in response to high summer temperatures. Subsequent analyses indicated copper levels were well within limits. SRS and SCDHEC have completed discussions regarding a consent agreement with final approval anticipated in 2013. SRS did not receive any NOAVs in 2012. NOVs/NOAVs received from 2008 through 2012 are summarized in Table 3-4.

Table 3-4 SRS NOV/NOAV Summary, 2008 - 2012

\begin{tabular}{|l|c|c|c|c|c|}
\hline \multirow{2}{*}{ Program Area } & \multicolumn{5}{c|}{ NOV/NOAV } \\
\cline { 2 - 6 } & 2012 & 2011 & $\mathbf{2 0 1 0}$ & $\mathbf{2 0 0 9}$ & $\mathbf{2 0 0 8}$ \\
\hline CAA & 0 & 0 & 2 & 0 & 1 \\
\hline CWA & 1 & 0 & 0 & 0 & 2 \\
\hline RCRA & 0 & 0 & 0 & 0 & 0 \\
\hline CERCLA & 0 & 0 & 0 & 0 & 0 \\
\hline Others & 0 & 0 & 0 & 0 & 0 \\
\hline Total Violations & $\mathbf{1}$ & $\mathbf{0}$ & $\mathbf{2}$ & $\mathbf{0}$ & $\mathbf{3}$ \\
\hline
\end{tabular}

\section{Environmental Occurrences}

The Occurrence Reporting and Processing System (ORPS), mandated by DOE Order 232.2, "Occurrence Reporting and Processing of Operations Information," is designated to "ensure that the DOE complex and the NNSA are informed of events that could adversely affect the health and safety of the public and workers, the environment, DOE missions, or the credibility of the Department." The ORPS system promotes "organizational learning consistent with DOE’s Integrated Safety Management System goal of enhancing mission safety, and sharing effective practices to support continuous improvement and adaptation to change."

Of the 116 ORPS-reportable events at SRS in 2012 (including all contractors), there were three ORPS reportable events within ORPS Group 5 (Environmental) or ORPS Group 9 (Noncompliance Notification). The three ORPS reportable events are described below:

- On June 12, 2012, sanitary wastewater (sewage) overflowed a manhole because a lift station was not operating. This event was categorized as an ORPS Reportable 5A(2), "any release (onsite or offsite) of a pollutant from a DOE facility that is above levels or limits specified by outside agencies in a permit, license, or equivalent authorization, when reporting is required in a format other than routine periodic reports."

- On June 20, 2012, SRS personnel collected a composite sample at the H-12 outfall to fulfill the requirements of the NPDES permit for this outfall. The analytical results of the sample were in excess of both the monthly average limits and the daily maximum limit. SRS notified SCDHEC and DOE as required per the permit. This event was categorized as both an ORPS Reportable 5A(2) and an ORPS Reportable 9(1), "any written notification from an outside regulatory agency that a site/facility is considered to be in noncompliance with a schedule or requirement."

- On November 13, 2012, SRS personnel obtained an NPDES compliance sample from the H-02 outfall. The results from the sample showed a zinc level that exceeded the daily maximum allowable limit. It was determined that a noncompliance had occurred. This event was categorized as both an ORPS Reportable 5A(2) an ORPS Reportable 9(1). 


\section{Environmental Audits}

The primary objectives of SRS environmental program assessments are to: 1) ensure compliance with regulatory requirements and 2) to foster continuous improvement. A number of organizations, both outside and within the DOE complex, review the SRS environmental program. In 2012, assessment of the environmental program consisted of self and independent assessments. The assessments ensure the recognition of noteworthy practices, the identification of performance deficiencies, and the initiation and tracking of associated corrective actions until they are satisfactorily completed. In addition, the environmental program assessment is an integral part of the SRS Integrated Safety Management System and supports the SRS EMS, which continues to meet the guidelines of International Organization for Standardization Standard 14001. (ISO 14000 is a family of voluntary environmental management standards and guidelines.) The Site Tracking, Analysis, and Reporting system is a database used for scheduling self-assessments, as well as for (1) documenting their results and any issues or concerns identified, (2) tracking corrective actions to closure, and (3) trending accumulated data for process improvement.

SRS also conducted 17 environmental program level self-assessments in 2012. The self-assessment topic, the purpose of the assessment and a summary of the results follow in Table 3-5. DOE-SR conducted 232 independent functional area environmental protection assessments and participated in various capacities on the contractor environmental program level self-assessments.

SCDHEC, EPA, and the USACE conducted external inspections and audits of the SRS environmental program for regulatory compliance. Table 3-6 provides a summary of the results of the 2012 audits and inspections.

Table 3-5 2012 SRS Self-Assessment Summary

\begin{tabular}{|c|c|c|}
\hline Assessment Area & Purpose & Results \\
\hline Waste Management & $\begin{array}{l}\text { Evaluate the procurement of offsite hazardous waste } \\
\text { treatment, storage and disposal (TSD) services. }\end{array}$ & No issues were identified. \\
\hline Waste Management & $\begin{array}{l}\text { Evaluate WMin/P2 efforts for several SRS waste gen- } \\
\text { erators. }\end{array}$ & No issues were identified. \\
\hline $\begin{array}{l}\text { National Pollutant } \\
\text { Discharge } \\
\text { Elimination System }\end{array}$ & $\begin{array}{l}\text { Evaluate the process of generating the SRS Discharge } \\
\text { Monitoring Report (DMR). }\end{array}$ & No issues were identified. \\
\hline $\begin{array}{l}\text { Liquid Effluent } \\
\text { Monitoring Program }\end{array}$ & $\begin{array}{l}\text { Ensure that the SRS Radiological Liquid Effluent Moni- } \\
\text { toring Program meets DOE orders and Site procedures. }\end{array}$ & $\begin{array}{l}\text { Assessors identified two issues: } \\
\text { (1) procedures require updating } \\
\text { to include sampling require- } \\
\text { ments, and (2) include the re- } \\
\text { sults of this assessment in a pro- } \\
\text { cedure. Corrective actions were } \\
\text { approved and implemented. }\end{array}$ \\
\hline $\begin{array}{l}\text { Domestic Water } \\
\text { Quality }\end{array}$ & $\begin{array}{l}\text { Ensure Site drinking water meets all Federal and State } \\
\text { regulatory requirements and engineering design stan- } \\
\text { dards. }\end{array}$ & No issues were identified. \\
\hline $\begin{array}{l}\text { Groundwater } \\
\text { Sampling and } \\
\text { Analysis Plan }\end{array}$ & $\begin{array}{l}\text { Ensure data acquisition and management is sufficient to } \\
\text { protect groundwater at SRS. }\end{array}$ & No issues were identified. \\
\hline
\end{tabular}


Table 3-5 2012 SRS Self-Assessment Summaries (Continued)

\begin{tabular}{|c|c|c|}
\hline Assessment Area & Purpose & Results \\
\hline $\begin{array}{l}\text { SRS Groundwater } \\
\text { Sampling Program }\end{array}$ & $\begin{array}{l}\text { Ensure programmatic elements of the SRS Groundwater } \\
\text { Sampling Program are transitioned during reorganiza- } \\
\text { tion or staff turnover. }\end{array}$ & No issues were identified. \\
\hline $\begin{array}{l}\text { Meteorological } \\
\text { Monitoring }\end{array}$ & $\begin{array}{l}\text { Ensure conformance with DOE Order } 458.1 \text { and NES- } \\
\text { HAP. }\end{array}$ & No issues were identified. \\
\hline RCRA Permitting & $\begin{array}{l}\text { Ensure that RCRA submittals to SCDHEC are prepared } \\
\text { and submitted in accordance with all applicable require- } \\
\text { ments. }\end{array}$ & No issues were identified. \\
\hline Spills and Releases & $\begin{array}{l}\text { Ensure the adequacy and effectiveness of the Health and } \\
\text { Safety Release Reporting Requirements. }\end{array}$ & No issues were identified. \\
\hline $\begin{array}{l}\text { Laboratory and } \\
\text { Field Quality } \\
\text { Assurance }\end{array}$ & $\begin{array}{l}\text { Ensure SRS laboratories certified by SCDHEC provide } \\
\text { representative, defensible data. }\end{array}$ & No issues were identified. \\
\hline NEPA & $\begin{array}{l}\text { Evaluate the benefits/limitations of electronic notifi- } \\
\text { cation to subject matter experts (SMEs) for Site level } \\
\text { NEPA reviews. }\end{array}$ & No issues were identified. \\
\hline $\begin{array}{l}\text { Air Quality } \\
\text { Protection }\end{array}$ & $\begin{array}{l}\text { Ensure the SRS Radiological Air Quality Protection Pro- } \\
\text { gram is in conformance with applicable DOE orders and } \\
\text { Site procedures. }\end{array}$ & No issues were identified. \\
\hline $\begin{array}{l}\text { Environmental } \\
\text { Radiation } \\
\text { Protection }\end{array}$ & $\begin{array}{l}\text { Ensure that the environmental dosimetry used at SRS } \\
\text { is properly documented and meets regulatory require- } \\
\text { ments. }\end{array}$ & No issues were identified. \\
\hline $\begin{array}{l}\text { Environmental } \\
\text { Quality Assurance }\end{array}$ & $\begin{array}{l}\text { Ensure the SCDHEC certified SRS laboratories sam- } \\
\text { pling and analysis procedures are consistent with the ap- } \\
\text { plicable laboratory and field sampling quality assurance } \\
\text { criteria. }\end{array}$ & No issues were identified. \\
\hline $\begin{array}{c}\text { Environmental } \\
\text { Management } \\
\text { Functions }\end{array}$ & $\begin{array}{l}\text { Ensure the SRS Environmental Management System } \\
\text { Annual Report identifies and addresses environmental } \\
\text { sustainability goals and performance. }\end{array}$ & No issues were identified. \\
\hline $\begin{array}{l}\text { SRS Stormwater } \\
\text { Outfall Assessment }\end{array}$ & $\begin{array}{l}\text { Evaluate the accuracy of stormwater outfall classifica- } \\
\text { tions at SRS. }\end{array}$ & $\begin{array}{l}\text { The assessment identified sev- } \\
\text { eral stormwater outfalls that } \\
\text { should be reclassified from ad- } \\
\text { ministrative to industrial. Cor- } \\
\text { rective actions were approved } \\
\text { and implemented. }\end{array}$ \\
\hline
\end{tabular}


Table 3-6 2012 External Audits/Inspections and Results

\begin{tabular}{|c|c|c|}
\hline Audit/Inspection & Purpose & Results \\
\hline $\begin{array}{l}\text { Compliance Sampling } \\
\text { Inspection of NPDES } \\
\text { Facilities }\end{array}$ & SCDHEC inspected NPDES facilities. & $\begin{array}{l}\text { Initial feedback was positive. } \\
\text { The final report is pending. } \\
\text { No issues were identified. }\end{array}$ \\
\hline $\begin{array}{l}\text { Compliance Evaluation } \\
\text { Inspection (CEI) of } \\
\text { D-Area NPDES Facilities }\end{array}$ & $\begin{array}{l}\text { SCDHEC inspected NPDES wastewater outfalls at } \\
\text { the D-Area Powerhouse in } 2012 .\end{array}$ & No issues were identified. \\
\hline $\begin{array}{l}\text { CEI of Land } \\
\text { Application Site }\end{array}$ & $\begin{array}{l}\text { SCDHEC inspected the SRS NDPES land } \\
\text { application site. }\end{array}$ & No issues were identified. \\
\hline Stormwater Inspection & SCDHEC inspected SRS NPDES stormwater outfalls. & $\begin{array}{l}\text { The inspection resulted in an } \\
\text { unsatisfactory rating, noting } \\
\text { that one stormwater outfall } \\
\text { was not incorporated into the } \\
\text { SRS Stormwater Pollution } \\
\text { Prevention Plan. SRS took } \\
\text { immediate corrective actions } \\
\text { to resolve the deficiency. }\end{array}$ \\
\hline $\begin{array}{c}\text { Underground Storage } \\
\text { Tank CEI }\end{array}$ & SCDHEC inspected 19 SRS USTs. & $\begin{array}{l}\text { All USTs are in compliance, } \\
\text { marking } 10 \text { years without a } \\
\text { violation. }\end{array}$ \\
\hline $\begin{array}{c}\text { SRS Environmental } \\
\text { Monitoring, } \\
\text { Environmental Analysis, } \\
\text { and } \\
\text { Domestic Water } \\
\text { Laboratories Evaluation }\end{array}$ & $\begin{array}{l}\text { SCDHEC's Office of Environmental Laboratory Cer- } \\
\text { tification audited the three SRS laboratories to sup- } \\
\text { port laboratory certification renewal. Laboratory pro- } \\
\text { cedures, practices, and records were reviewed, and } \\
\text { personnel were interviewed. }\end{array}$ & $\begin{array}{l}\text { No issues were identified. } \\
\text { SCDHEC granted new certi- } \\
\text { fications that expire in } 2015 \text {. }\end{array}$ \\
\hline $\begin{array}{l}\text { Infectious Waste } \\
\text { Inspection }\end{array}$ & $\begin{array}{l}\text { SCDHEC Department of Health inspected the medi- } \\
\text { cal waste storage are in } 719-5 \mathrm{~N} \text {. }\end{array}$ & No issues were identified. \\
\hline $\begin{array}{l}\text { Air Programs } \\
\text { Compliance Inspection }\end{array}$ & $\begin{array}{l}\text { SCDHEC inspected SRS facilities for compliance } \\
\text { with State and Federal air quality regulations and air } \\
\text { quality permits. }\end{array}$ & No issues were identified. \\
\hline
\end{tabular}


Table 3-6 2012 External Audits/Inspections and Results (Continued)

\begin{tabular}{|c|c|c|}
\hline Audit/Inspection & Purpose & Results \\
\hline $\begin{array}{l}\text { Z-Area Saltstone Solid } \\
\text { Waste Landfill } \\
\text { Inspections }\end{array}$ & $\begin{array}{l}\text { SCDHEC initially performed inspections of SDF, } \\
\text { Vault } 4 \text { exterior conditions, to observe existing and } \\
\text { potential moisture areas on a weekly basis. During } \\
\text { 2012, SCDHEC reduced the frequency to monthly. }\end{array}$ & $\begin{array}{l}\text { SRS detected moisture areas } \\
\text { on the exterior walls of SDF } \\
\text { Vault } 4 \text {. In accordance with } \\
\text { the SDF's contingency plan, } \\
\text { SRS reported this observa- } \\
\text { tion to SCDHEC. Moisture } \\
\text { areas on the SDF, Vault } 4 \\
\text { exterior walls, are due to a } \\
\text { combination of factors: salt- } \\
\text { stone shrinkage from grout } \\
\text { curing, bleed and process } \\
\text { water accumulation at inside } \\
\text { of the exterior wall, and hy- } \\
\text { drostatic pressure causing } \\
\text { water to weep through pre- } \\
\text { existing construction cracks. } \\
\text { SCDHEC has not mandated } \\
\text { any additional actions other } \\
\text { than monitoring of the SDF } \\
\text { Vault } 4 \text { via these inspections. }\end{array}$ \\
\hline $\begin{array}{c}\text { Comprehensive } \\
\text { Groundwater Monitoring } \\
\text { Evaluation }\end{array}$ & $\begin{array}{l}\text { SCDHEC inspected SRS groundwater facilities asso- } \\
\text { ciated with the F-Area and H-Area Seepage Basins, } \\
\text { M-Area Settling Basin, Metallurgical Laboratory Ba- } \\
\text { sin, Mixed Waste Management Facility, and Sanitary } \\
\text { Landfill. A records review of groundwater related files } \\
\text { was also completed. }\end{array}$ & $\begin{array}{l}\text { A damaged well sign at Well } \\
\text { HSB-107C (H Area) was ob- } \\
\text { served during the inspection. } \\
\text { The sign was replaced, and } \\
\text { no other issues were noted. }\end{array}$ \\
\hline $\begin{array}{l}\text { Industrial Wastewater } \\
\text { Construction Permit } \\
\text { Inspections }\end{array}$ & $\begin{array}{l}\text { SCDHEC conducted inspections throughout } 2012 \text { to } \\
\text { approve the operation or closure of a variety of in- } \\
\text { dustrial wastewater treatment projects including the } \\
\text { 105-C Disassembly Basin Evaporators, industrial } \\
\text { wastewater permitted facilities in D Area, the Western } \\
\text { Sector Treatment System, the Enhanced Low-Activity } \\
\text { Waste Disposal Modification at the SPF, and Tanks } \\
\text { 18F and 19F in the F-Area Tank Farm. }\end{array}$ & No issues were identified. \\
\hline USACE CEI & $\begin{array}{l}\text { The USACE conducted a compliance inspections of } \\
\text { Highway 125/Road } 2 \text { Intersection Improvement Proj- } \\
\text { ect permitted as required by NWP } 14 \text { (2010), and the } \\
\text { Ameresco Stormwater Outfall Project into LTR. }\end{array}$ & No issues were identified. \\
\hline RCRA CEI & $\begin{array}{l}\text { SCDHEC inspected nine Site facilities during a three- } \\
\text { day period and reviewed hazardous waste program } \\
\text { requirements (i.e., notifications and reports to SCD- } \\
\text { HEC, plans, training records, internal inspections, and } \\
\text { waste documentation). }\end{array}$ & $\begin{array}{l}\text { SCDHEC reported SRS is in } \\
\text { compliance with all applica- } \\
\text { ble provisions of the hazard- } \\
\text { ous waste regulations. }\end{array}$ \\
\hline
\end{tabular}


Table 3-6 2012 External Audits/Inspections and Results (Continued)

\begin{tabular}{|c|l|l|}
\hline Audit/Inspection & \multicolumn{1}{|c|}{ Purpose } & \multicolumn{1}{c|}{ Results } \\
\hline $\begin{array}{c}\text { 632-G C\&D Landfill, } \\
\text { 288-F Landfill, 488-4D } \\
\text { Ash Landfill Inspections }\end{array}$ & $\begin{array}{l}\text { SCDHEC conducted ten inspections of the landfills } \\
\text { during 2012. }\end{array}$ & No issues were identified. \\
\hline $\begin{array}{c}\text { Interim Sanitary Landfill } \\
\text { Post-Closure Inspection }\end{array}$ & SCDHEC conducted an annual review of the landfill. & $\begin{array}{l}\text { SCDHEC reported SRS is in } \\
\text { compliance with all applica- } \\
\text { ble provisions of the hazard- } \\
\text { ous waste regulations. }\end{array}$ \\
\hline
\end{tabular}

\section{Regulatory Self-Disclosures}

The Management of Treatability Study Residues at SRNL - On May 14, 2012, SRS laboratory personnel discovered that approximately 40 liters of sample and residues had not been returned to the sample collector after the study was completed. Laboratory personnel conducted the study in 2011 to evaluate the effectiveness of a new solvent for use in the radioactive liquid waste treatment process. The study was completed and a final report issued in November 2011. The laboratory had until December 10, 2011 to either return the sample residues to the sample collector or begin managing them as hazardous/mixed waste in an approved storage area.

The waste was stored in a closed container with secondary containment and managed by personnel that had all the required training; however, the container was not labeled as containing hazardous/mixed waste and was not stored in an approved storage area. Once discovered, personnel immediately labeled the container and placed the container into an approved storage area. SRS environmental personnel also inspected other areas of the laboratory looking for any other residues not managed properly. This inspection did not identify any other instances of improper management of residues. As a corrective action, researchers received management of treatability study residues remedial training, and the SRNL training program was enhanced. In addition, laboratory supervision assigned treatability study coordinators and increased the frequency of treatability study self-assessments. Laboratory personnel also updated the treatability study database and inventory reporting program.

Small Chemical-Based Fire in Laboratory Waste Bin - On December 10, 2012, a researcher at the SRNL was troubleshooting a problem with an instrument in a nonradiological lab. In the course of the work, the researcher discarded an empty cardboard box, a paper filter, a pair of nitrile gloves with carbon residue on them and some chemical products into a rolling waste receptacle. The chemicals were desiccants from glass columns on the instrument. The researcher heard a crackling sound, went to the waste receptacle, and observed small flames. He safely rolled the waste receptacle away from the wall into the center of the room and notified the SRNL Control Room (CR). The SRNL CR notified the fire department. An operator discharged a fire extinguisher into the waste receptacle. Laboratory personnel secured the room until fire department personnel arrived. A fire marshal initiated an evaluation of the contents of the waste receptacle. No hazardous residues remained after the fire. There were no personnel injured during this incident. The discarded desiccants included magnesium perchlorate, which is a Department of Transportation (DOT) oxidizer and a hazardous waste. SRS is conducting an incident investigation. SRS will distribute a report identifying the causes and corrective actions upon completion of the investigation. SRS will send this information to SCDHEC as soon as it is available.

Demonstration Project Operations with Expired Approval - SRS submitted a summary report in May 2012 in response to an incident in 2011 in which SCDHEC issued an extension to continue operation of the Dynamic Underground Stripping (DUS) Industrial Wastewater Demonstration Project. SRS later discovered the approval of the DUS pilot study had expired. SCDHEC extended the approval until December 2012 contingent upon submittal of an industrial wastewater construction permit application in 2011 and provided supplemental information in 2012. SCDHEC issued a construction permit (19,609-IW) on November 7, 2012 and SRS received approval from SCDHEC to place the system (now referred to as the WSTS) into operation on December 3, 2012. 


\section{Continuous Release Reporting}

EPCRA (40 CFR 355.40) requires that reportable releases of extremely hazardous substances or CERCLA hazardous substances be reported to any local emergency planning committees and state emergency response commissions likely to be affected by the release. SRS had no EPCRA-reportable releases in 2012.

\section{Unplanned Releases}

Federally permitted releases comply with legally enforceable licenses, permits, regulations, or orders. If an unpermitted release to the environment of an amount greater than or equal to a reportable quantity (RQ) of a hazardous substance (including radionuclides) occurs, CERCLA requires notification to the National Response Center. Reportable quantities are those quantities of a hazardous substances greater than or equal to values specified in Table 302.4 (“Designation of Hazardous Substances”) of 40 CFR 302 ("Designation, Reportable Quantities, and Notification”). SRS had no CERCLA reportable releases in 2012. The CWA requires SRS to notify the National Response Center if an oil spill causes sheen on navigable waters, such as rivers, lakes, or streams.

SRS made one notification to SCDHEC in 2012 due to a sewer system overflow at the 607-31F lift station (720 gallons). SRS recorded and cleaned up the following spills that did not require reporting as required by CERCLA or to SCDHEC because they were below the RQ: 6 chemical, 4 sewage, and 35 petroleum product spills. None of the small oil spills that occurred in 2012 required a call to the National Response Center.

\section{Permits}

SRS had 518 construction and operating permits in 2012 that specified operating levels to each permitted source. Table 3-7 identifies these permits. These numbers, which reflect permits for all primary contractors and tenant organizations at SRS, with the exception of Ameresco, include some permits voided or closed during 2012.

Table 3-7 SRS Construction and Operating Permits 2012

\begin{tabular}{|l|c|}
\hline \multicolumn{1}{|c|}{ Type of Permit } & Number of Permits \\
\hline Air & 7 \\
\hline USACE - Section 10, Rivers \& Harbors Act of 1899 & 1 \\
\hline USACE Nationwide Permit & 4 \\
\hline USACE - 404 Permit (Dredge and Fill) & 1 \\
\hline Asbestos Demolition/Abatement & 27 \\
\hline Domestic Water & 222 \\
\hline Industrial Wastewater & 77 \\
\hline NPDES Discharge & 3 \\
\hline NPDES No Discharge & 1 \\
\hline NPDES General Utility Water Permit & 1 \\
\hline Stormwater Discharge & 1 \\
\hline Construction Stormwater Grading Permit & 8 \\
\hline RCRA Hazardous Waste & 1 \\
\hline RCRA Solid Waste & 4 \\
\hline RCRA Underground Storage Tank & 7 \\
\hline Sanitary Wastewater & 121 \\
\hline SC Department of Natural Resources Scientific Collecting Permit & 1 \\
\hline SCDHEC 401 & 2 \\
\hline SCDHEC Navigable Waters & 1 \\
\hline Underground Injection Control & 28 \\
\hline TOTAL & $\mathbf{5 1 8}$ \\
\hline \hline
\end{tabular}




\section{EFFLUENT MONITORING}

Lori Coward

Jana D. Ackerman

John Adams

Greta Fanning

Martha Thompson

Environmental Compliance \& Area Completion Projects

\section{Timothy Jannik}

Savannah River National Laboratory

The Savannah River Site (SRS) conducts effluent monitoring to demonstrate compliance with applicable standards

1 and regulations in accordance with specific Environmental Protection Agency (EPA), South Carolina Department of Health and Environmental Control (SCDHEC) and Department of Energy (DOE) sampling and analytical procedures.

SRS conducts monitoring activities for the following effluent categories:

- Radiological airborne effluent,

- Radiological liquid effluent,

- Nonradiological airborne effluent, and

- Nonradiological liquid effluent.

In 2012, effluent releases for radiological airborne and liquid effluent and nonradiological airborne effluent were below permit limits and applicable standards. Six nonradiological liquid effluent samples taken to demonstrate compliance with the National Pollutant Discharge Elimination System (NPDES) permit requirements exceeded permit limits. Details on these six exceptions are discussed in Chapter 3, “Compliance Summary,” Table 3-2.

This chapter presents a summary of the effluent monitoring programs and data results.

\section{Radiological Monitoring}

Analytical results from radiological effluent monitoring are a major component in demonstrating compliance with standards for radiological doses to the public established by EPA and DOE. SRS works to ensure that radiation exposures to employees and that releases of radioactivity to the environment remain below regulatory limits, and takes deliberate actions to further reduce exposures and releases.

EPA's National Emission Standards for Hazardous Air Pollutants (NESHAP) program establishes the requirements and limits that regulate radionuclide emissions from facilities owned or operated by DOE. Subpart H of 40 Code of Federal Regulations (CFR) 61 details the methods for estimating and reporting radioactive emissions from point sources. SCDHEC regulates both radioactive and nonradioactive air pollutant emissions from SRS sources. SCDHEC permits each major source of air emissions on the SRS Part 70 Air Quality Permits with specific limitations and monitoring requirements.

This chapter presents brief summaries of analytical results; the CD housed inside the back cover of this report contains complete data sets, as well as maps which show sampling locations. Tables on the CD ("Environmental Data/Maps - 2012") are denoted in this chapter as "Data Table 4-X.” Tables in the chapter itself are referred to simply as "Table 4-X.” Data Tables 4-1 and 4-2 provide a summary of analytical results for radioactive air and liquid effluent measurements taken at SRS in 2012. Radioactive atmospheric and liquid release data by facility function are contained in Data Tables 4-3 and 4-4.

Alpha and beta radiation releases from unidentified radionuclides in airborne and liquid emissions make up a large percentage of the offsite doses. Data Tables 4-3 and 4-4 list separately the unidentified alpha and unidentified beta radiation releases. These release results are determined by subtracting the identified individual radionuclides from the measured gross activity. Conservatively, for purposes of analysis, unidentified alpha and unidentified beta releases include small amounts of unidentified manmade radionuclides as well as naturally occurring radionuclides, such as uranium, thorium, and potassium- 40 . 


\section{Airborne Emissions}

For process area stacks that release or have the potential to release radioactive materials, SRS has a variety of methods used to estimate the emissions. SRS uses one of these three methods: an inline system, periodic sampling system, or approved calculation methods to estimate the emissions. Depending on the processes involved, SRS may also use real-time instrumentation to monitor discharge stacks to determine instantaneous and cumulative atmospheric releases (e.g., of tritium) to the environment.

\section{Calculated Sources}

SRS calculates radionuclide release estimates (in curies) from unmonitored diffuse and point sources on an annual basis. Radionuclides may be emitted from stacks or other exhaust points (such as vents) on buildings where radionuclide use is authorized and these are referred to as point sources. Point sources may also be reported by combining the emissions of similar type sources (e.g., hoods and vents). SRS does not combine radionuclide releases and thus does not report grouped sources. Alternatively, emissions from diffuse sources are not actively ventilated or exhausted. Diffuse emissions may not originate from a single location, but are released over a larger discrete area. SRS diffuse sources include evaporative emissions, research laboratories, disposal sites and storage tanks, as well as deactivation and decommissioning activities. These estimates are included in the SRS radioactive release totals in Data Table 4-3.

SRS calculates unmonitored releases using the methods contained in 40 CFR 61 Appendix D (EPA, 1989). Because these methods employ conservative assumptions, they generally lead to overestimation of actual emissions. Although SRS does not monitor these releases at their source, onsite and offsite environmental surveillance monitoring stations are in place to quantify unexpected airborne emission releases. Additional information can be found in Chapter 5, "Environmental Surveillance."

\section{Releases Summary}

SRS quantifies the total amount of radioactive material released to the environment by using (1) data obtained from monitored airborne effluent release points, (2) estimates of diffuse sources, and (3) estimates for unmonitored air sources based on approved EPA calculation methods.

Data Table 4-3 presents year-end estimates of the radiological airborne emissions from SRS that have been transmitted to the regulators. These estimates include monitored, unidentified alpha and beta, calculated diffuse and point source releases, and annual totals based on actual operation time. Also included in Data Table 4-3 are the calculated radionuclides released based on the history of the spent fuel that was dissolved in the $\mathrm{H}$ Canyon facility (291-H). The dissolution process releases gaseous and vaporous radionuclides (i.e., krypton-85, carbon-14, and tritium oxide) that are not captured in the 291- $\mathrm{H}$ stack sampling system.

\section{Tritium}

Tritium releases in elemental and oxide forms make up the majority of the airborne radionuclide releases from SRS. More than 65\% of the total radioactivity released to the atmosphere from SRS operations in 2012 is attributed to tritium. Data Table 4-3 details the remaining 35\%. SRS released about 16,700 curies (Ci) of tritium in 2012, compared with approximately 28,100 $\mathrm{Ci}$ in 2011. Approximately $87 \%$ of the releases came from the five tritium processing facilities in $\mathrm{H}$ Area. A small amount $(\sim 9 \mathrm{Ci})$ of tritium was released from the dissolution of spent nuclear fuel in the H Canyon facility (291-H). The remainder is split between the Reactor Areas and the estimated releases from ongoing remediation and restoration activities. The amount of tritium released from SRS fluctuates because of changes in the SRS missions and in the annual production schedules of the tritium processing facilities. The reduction in tritium releases in 2012 is primarily due to the relocation of the helium-3 recovery process from a 1966-vintage facility into a more modern and efficient facility. For the past 10 years, the airborne tritium releases have ranged between about 17,000 to 60,000 Ci per year (Figure 4-1). 


\section{Comparison of Average Concentrations in Airborne Emissions to DOE Derived Concentration Standards}

SRS uses laboratory analyses of samples to determine concentrations of radionuclides in airborne emissions. The annual average concentrations are compared to the DOE derived concentration standards (DCSs) invoked by DOE Order 458.1, "Radiation Protection of the Public and the Environment," as a screening method to determine if existing effluent treatment systems are appropriate and effective. SRS uses the same DCSs as reference concentrations for conducting environmental protection programs that are used at all DOE sites. DCSs are applicable at the point of discharge. The DCSs were developed by DOE and are documented in DOE Derived Concentration Technical Standard (DOE, 2011a).

Data Table 4-5 provides the 2012 atmospheric effluent annual average concentrations and comparisons against the DOE DCSs by monitored discharge point. Also included in Data Table 4-5 are the concentrations of these radionuclides released, calculated based on the history of the spent fuel that was dissolved in the H Canyon facility (291-H).

SRS bases this DCS comparison on isotopic concentrations; the average concentration is determined only if there is at least one significant result for the isotope. With the exception of tritium releases (from several facilities) and calculated gaseous radionuclides (only from the $\mathrm{H}$ Canyon facility), the concentrations reported in Data Table 4-5 correspond only to the emissions that occur during sampling events. Concentrations for other periods, including any time between stack samples, gross alpha and gross beta results, and other emissions estimated using calculations, are not included in Data Table 4-5.

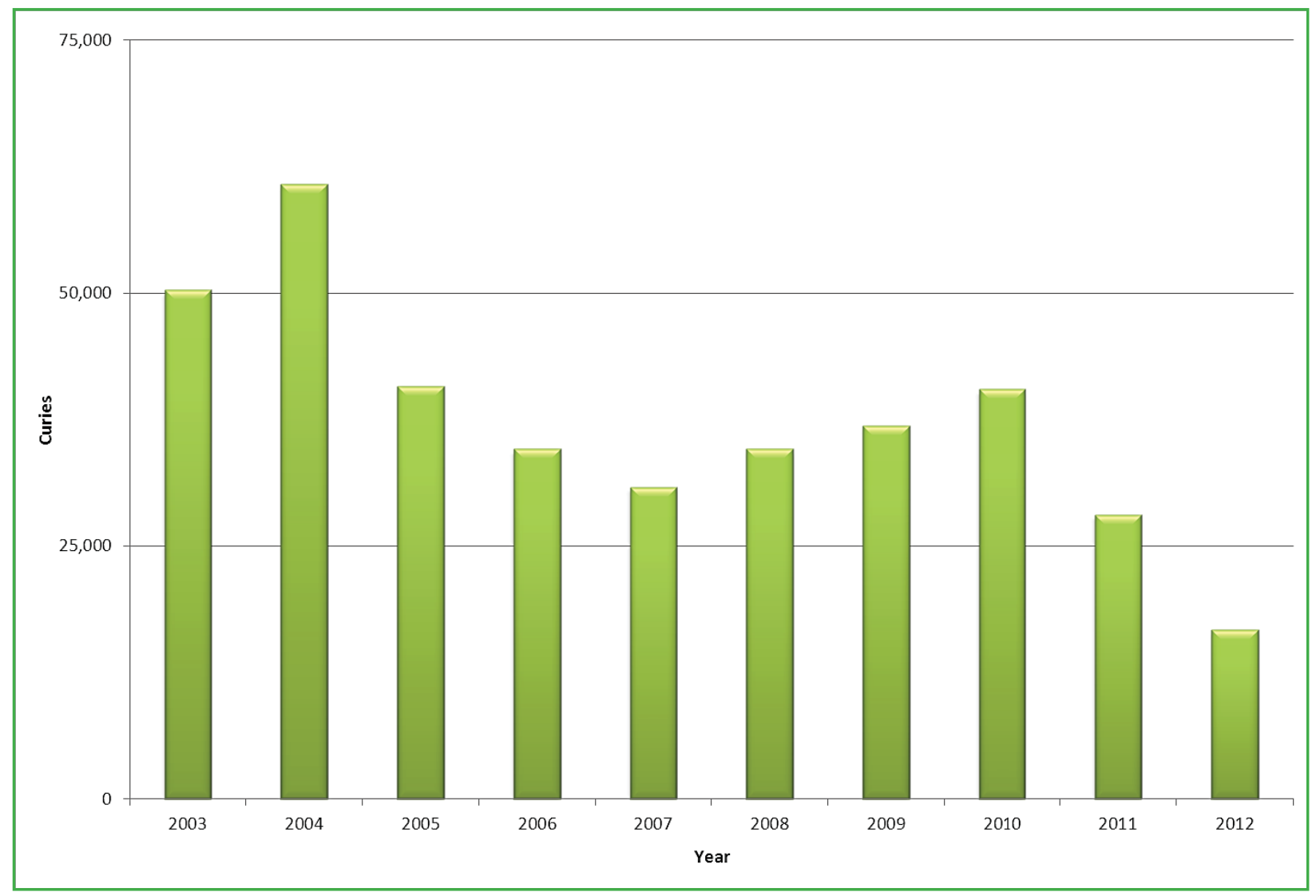

Figure 4-1 Ten-Year History of SRS Annual Atmospheric Tritium Releases 
Most of the SRS radiological stacks/facilities release small quantities of radionuclides at concentrations below the DOE DCSs. Figure 4-2 illustrates a typical SRS stack. Because of the nature of the operations and the application of DCSs at the release point, K Area, L Area, and the tritium facilities routinely exceed tritium DCSs. However, the offsite dose from all atmospheric releases remained well below the DOE and EPA annual atmospheric pathway dose standard of 10 mrem (0.1 mSv), as discussed in Chapter 6, "Radiological Dose Assessments."

\section{Liquid Effluents}

SRS routinely samples and analyzes for radioactivity at each liquid effluent discharge point that releases or has potential to release radioactive materials. Depending on the processes involved, SRS may also monitor liquid effluents with real-time instrumentation to ensure that releases are below DOE established limits. Because the instruments have limited detection sensitivity, SRS does not use inline monitoring systems to quantify liquid radioactive releases. Instead, SRS personnel collect samples for more sensitive laboratory analysis. As shown in Figure 4-3, surveillance and effluent sampling points are near SRS facilities, onsite streams, and on the Savannah River.

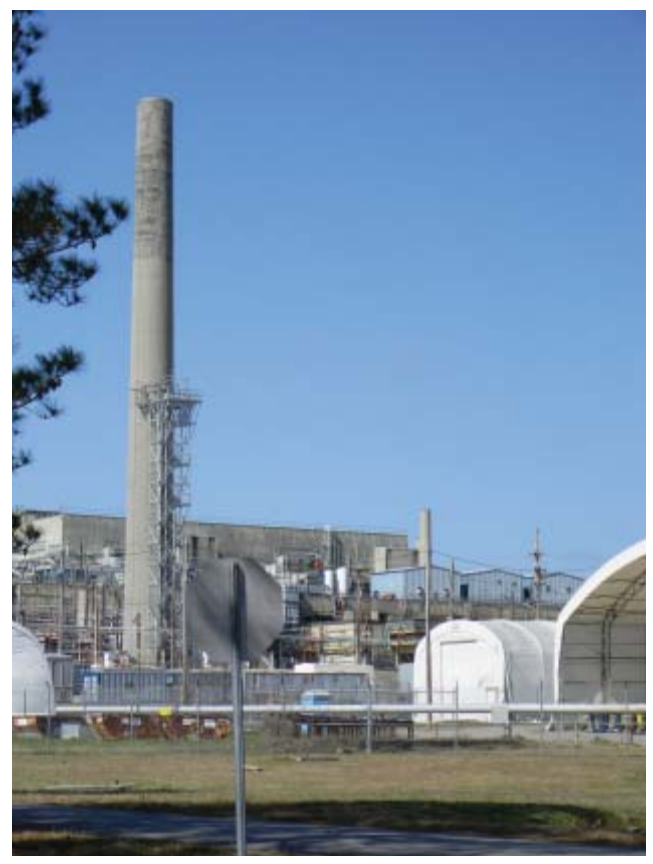

Figure 4-2 Typical SRS Facility Stack 


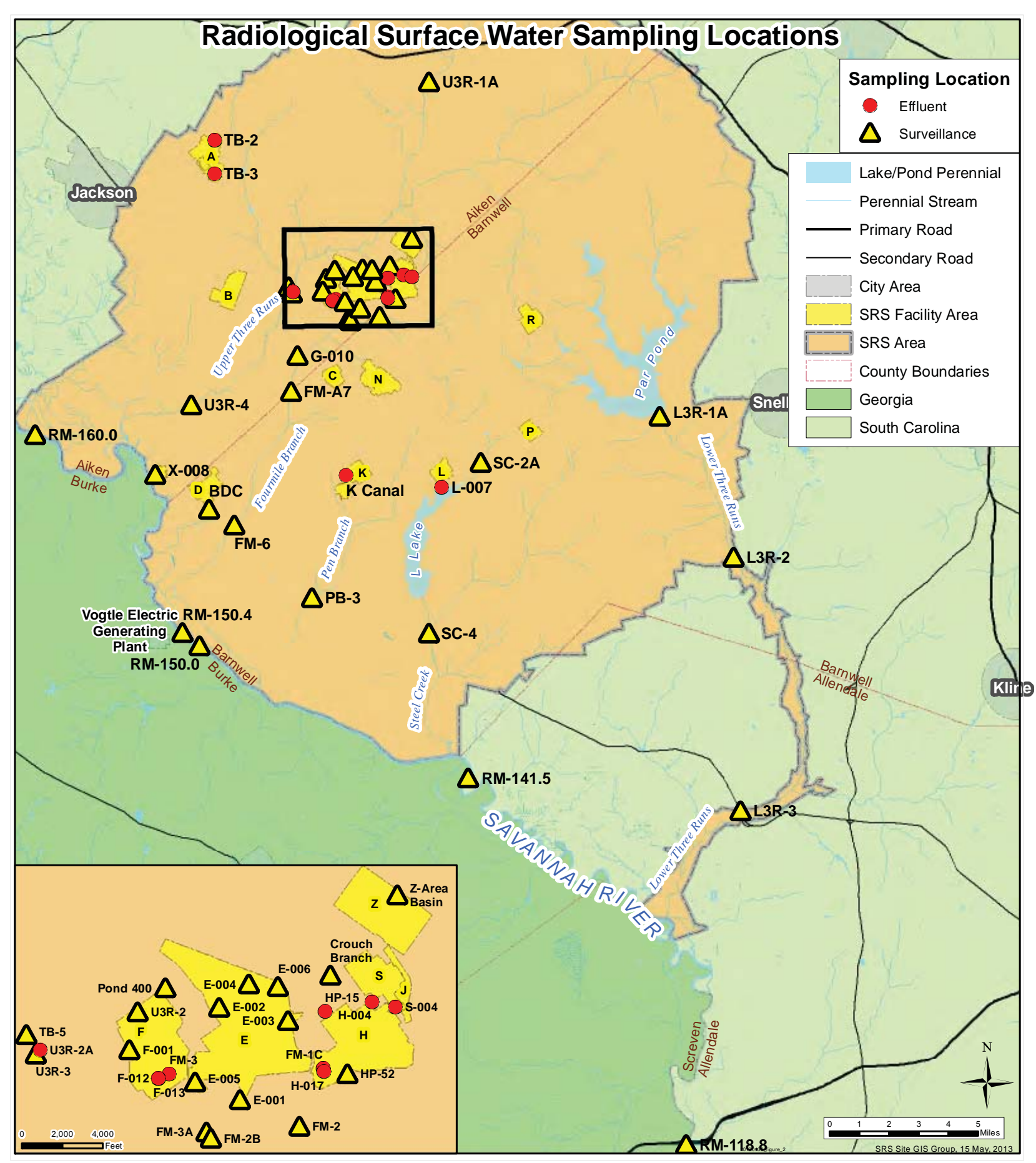

Figure 4-3 Radiological Surface Water Sampling Locations

\section{Releases Summary}

SRS uses data from monitored liquid effluent discharge points in conjunction with SRS seepage basin and Solid Waste Disposal Facility (SWDF) migration release estimates to quantify the tritium released to the Savannah River from SRS operations. Data Table 4-4 provides SRS liquid radioactive releases for 2012. These data are a major component in the determination of offsite dose consequences from SRS operations. Chapter 5, "Environmental Surveillance,” describes groundwater migration and transport of radionuclides from SRS seepage basins and the SWDF and includes a summary table (Table 5-9) of releases to the Savannah River. 


\section{Discharges of Liquid Effluents}

SRS quantifies discharges of liquid effluents at the point of release. SRS based the release totals on measured concentrations and measured flow rates. Tritium accounts for nearly all the radioactivity discharged in SRS liquid effluents. The total amount of tritium released directly from process areas to SRS streams during 2012 was 96 Ci. This is a significant decrease from the 138 Curies released in 2011. Figure 4-4 shows direct releases of tritium to SRS streams for the past ten years. As can be seen from the chart, the total direct release of tritium has been decreasing.

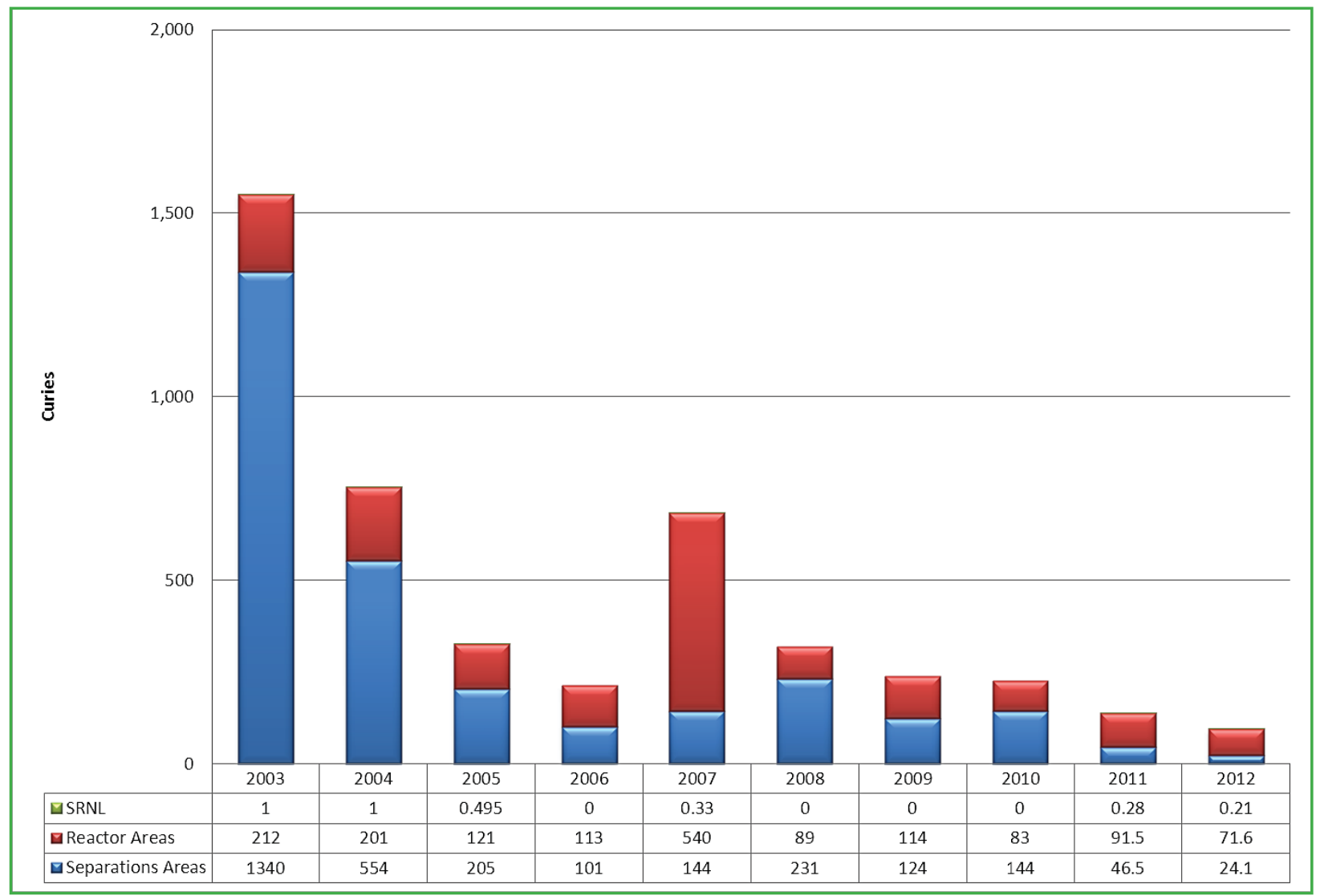

Figure 4-4 Ten-Year History of Direct Releases of Tritium to SRS Streams

\section{Comparison of Average Concentrations in Liquid Releases to DOE Derived Concentration Standards}

In addition to dose standards, DOE Order 458.1 imposes other control considerations on liquid releases. These considerations are applicable to direct discharges but not to seepage basin and groundwater discharges. The DOE order also requires comparison to DCS values for most radionuclides. The DCSs were developed by DOE and are documented in DOE Derived Concentration Technical Standard (DOE-STD-1196-2011)(DOE, 2011a).

DCSs are applicable at the point of discharge from the effluent conduit to the environment (prior to dilution or dispersion). According to DOE Order 458.1, exceedance of the DCSs at any discharge point may require an investigation of "best available technology" (BAT) waste treatment for the liquid effluents. DOE Order 458.1 specifically excludes tritium in liquid effluents from BAT requirements; however, DOE Order 458.1 does not exclude it from the requirement to keep radioactive emissions and external exposures as low as reasonably achievable. DOE DCS compliance is demonstrated when the sum of the fractional DCS values for all radionuclides detected in the effluent is less than 1.00, based on consecutive 12-month-average concentrations. Data Table 4-6 provides the 2012 liquid effluent annualaverage concentrations, the quantities of radionuclides released compared to the DOE DCSs by discharge point. All discharges in 2012 were well below the standards.

DCSs are based on a 100-mrem exposure and the highly conservative assumption that a member of the public has continuous direct access to the actual liquid. Because of security controls and the considerable distances between most SRS operating facilities and the SRS boundary, this scenario is highly improbable, if not impossible. 


\section{Nonradiological Monitoring}

\section{Airborne Emissions}

SCDHEC regulates nonradioactive criteria and toxic air pollutant emissions from SRS sources. SCDHEC permits, regulates, or exempts each source of air emissions in the SRS Part 70 Air Quality operating permit. Various SCDHEC and EPA air pollution control regulations and standards outline the bases for the limitations and monitoring requirements specified in the Part 70 Air Quality Permits. Many of the applicable standards are source-dependent (i.e., applicable to certain types of industries, processes, or equipment). See http://www.scdhec.gov/environment/baq/ Regulation-SIPManagement/ for the SCDHEC air standards for toxic air pollutants.

\section{Monitoring Program}

Major nonradiological emissions of concern from SRS facility stacks include sulfur dioxide, carbon monoxide, oxides of nitrogen, particulate matter, volatile organic compounds (VOCs), and toxic and hazardous air pollutants. The SRS Part 70 Air Quality Permit has numerous continuous and periodic monitoring requirements; only the most significant are discussed below.

The primary method of documenting source emissions at SRS is the annual air emissions inventory. Emissions from SRS sources are determined from standard calculations using source operating parameters, such as hours of operation, process throughput, and emission factors provided in the EPA "Compilation of Air Pollution Emission Factors," AP-42. However, many of the SRS processes are unique sources requiring nonstandard, complex calculations. SRS compares the hourly and total actual annual emissions for each source against their respective permit limitations.

SRS is required to perform stack compliance tests every two years at the A-Area biomass boiler. The tests include sampling of boiler exhaust gases to determine particulate matter. In addition, SRS personnel monitor and record opacity emissions during times of operation and perform weekly visual inspections. SRS conducted a compliance stack test at the A Area biomass boiler in February 2011. The next test is required prior to March 31, 2013.

All fuel oil-fired equipment operated on SRS must comply with sulfur dioxide standards, and SRS reports compliance to SCDHEC semiannually. The sulfur content of the fuel oil used at SRS must be below 0.05\%; SRS verifies compliance by analysis and requires the vendor to supply fuel certification for each delivery. The monitoring of SRS diesel-powered equipment includes tracking fuel oil consumption monthly and calculating a 12-month rolling total for determining permit compliance with a SRS consumption limit.

SRS has several soil vapor extraction units and two air strippers that are sources of toxic air pollutants and VOCs. SRS must sample monthly for VOC concentrations and calculate the total VOC emissions for comparison against a 12-month rolling limit. SRS currently reports the VOC emissions to SCDHEC on a quarterly basis.

Several SRS sources have pollutant control devices, such as electrostatic precipitators, baghouse dust collectors, or condensers; SRS must monitor these devices continuously or during operation; and record and compare the data against specific operating ranges.

SCDHEC assesses compliance of all SRS permitted sources during annual compliance inspections. The inspections include a review of each permit condition (e.g., daily monitoring readings, equipment calibrations, control device inspections, etc.); SCDHEC performed an air compliance inspection in May 2012 and found no instances of noncompliance.

\section{Releases Summary}

SRS is required to report its emissions inventory for all Site air emission sources annually to SCDHEC. SRS compiles operating data and calculates emission data for each calendar year. Data Table 4-7 provides a list of the 2008-2012 estimated emissions. 
Table 4-1 shows the total SCDHEC air emission estimates for all SRS permitted sources, as determined by the air emissions inventory conducted in each of the past five years. A review of the calculated emissions for each source for each calendar year determined that SRS sources had operated in compliance with permitted emission rates. Some toxic air pollutants (e.g., benzene) regulated by SCDHEC are, by nature, particulate matter or VOCs. As such, the total for VOCs in table 4-1 includes applicable toxic air pollutant emissions.

In April 2012, SRS permanently ceased all production operations at the D-Area Powerhouse facility, and on May 15, 2012, SCDHEC terminated the Part 70 Air Quality Permit TV-0300-0036. SRS continues to operate a biomass boiler and an oil-fired backup boiler in A Area. These two boilers are substantially smaller and burn cleaner than coal-fired boilers. The biomass boiler and oil-fired backup boiler each produce significantly less particulate matter, sulfur dioxide, and nitrogen dioxide emissions than coal-fired boilers.

SCDHEC issued a new Part 70 Air Quality Prevention of Significant Deterioration Construction Permit to Ameresco Federal Solutions, Inc. to construct two biomass boilers, each rated at a maximum heat input rate of 210 million British Thermal Units (BTU)/hr, one new oil-fired auxiliary boiler rated at 150 million BTU/hr, and two additional biomass boilers rated at 14.9 million BTU/hr. This new equipment replaced the D-Area Powerhouse facility.

The total diesel fuel consumption for portable air compressors, generators, emergency cooling water pumps, and firewater pumps was found to be well below the SRS limit for the entire reporting period. As reported to SCDHEC during 2012, the calculated annual VOC emissions were well below the permit limit for each unit.

\section{Ambient Air Quality}

Under existing regulations, SRS is not required to conduct onsite monitoring for ambient air quality; however, SRS is required to show compliance with various air quality standards. To accomplish this, SRS conducts air dispersion modeling as required in the Title $\mathrm{V}$ and construction permitting process.

Table 4-1 SRS Estimated SCDHEC Standard 2 Pollutant Air Emissions, 2008 - 2012 (TV-0080-0041 \& TV-0300-00036)

\begin{tabular}{|c|c|c|c|c|c|}
\hline \multirow{2}{*}{ Pollutant Name } & \multicolumn{5}{|c|}{ Emissions (Tons/Year) } \\
\hline & 2008 & 2009 & 2010 & 2011 & $2012^{b}$ \\
\hline Sulfur dioxide $\left(\mathrm{SO}_{2}\right)$ & 4,070 & 4,000 & 4,110 & 4,560 & 953 \\
\hline Total particulate matter (PM) & 459 & 399 & 803 & 329 & 26 \\
\hline $\begin{array}{l}\text { Particulate matter }<10 \text { micrometers } \\
(\text { PM10) }\end{array}$ & 313 & 264 & 637 & 142 & 18 \\
\hline $\begin{array}{l}\text { Particulate matter }<2.5 \text { micrometers } \\
(\mathrm{PM} 2.5)\end{array}$ & 265 & 222 & 136 & 427 & 16 \\
\hline Carbon monoxide (CO) & 673 & 40.7 & 44.6 & 125 & 52 \\
\hline $\begin{array}{l}\text { Volatile organic compounds } \\
\text { (VOCs) (Ozone Precursors) }^{\text {a }}\end{array}$ & 65.3 & 65 & 45 & 46 & 40 \\
\hline Gaseous fluorides (as hydrogen fluoride) & 12.2 & 12.2 & 12.2 & 12.3 & 3 \\
\hline Nitrogen dioxide $\left(\mathrm{NO}_{2}\right)$ & 1,890 & 1,790 & 2,060 & 2,060 & 621 \\
\hline Lead (lead and lead compounds) & 0.0267 & 0.034 & 0.0391 & 0.0166 & 0.00064 \\
\hline
\end{tabular}




\section{Liquid Effluents}

\section{Monitoring Program}

SRS monitors nonradioactive liquid discharges to surface waters through the NPDES, as mandated by the Clean Water Act. The NPDES permit program controls water pollution by regulating point sources that discharge pollutants into waters of the United States. SCDHEC administers the NPDES permit program under EPA authority. SCDHEC has issued permits to SRS for discharges to the waters of the United States, including South Carolina. These permits provide specific requirements for sampling locations, parameters to be tested, and monitoring frequency as well as analytical, reporting, and collection methods.

In 2012, activities at SRS resulted in discharges of water into SRS streams under six NPDES permits: three for industrial wastewater, SC0049107 (covers the Ameresco Biomass Cogeneration Facility), SC0047431 (covers D Area), and SC0000175 (covers remainder of SRS); one for stormwater runoff from industrial activities, SCR000000; one for stormwater runoff from construction activities, SCR100000; and one for general utility water, SC250273. The NPDES industrial wastewater discharge permit (Permit No. SC0049107) issued to Ameresco Federal Solutions, Inc. for discharges associated with the Biomass Cogeneration Facility is independent of SRS's permits and is reported separately. Figure 4-5 shows NPDES industrial wastewater outfall sampling locations. Figure 4-6 shows NPDES industrial stormwater outfall sampling locations.

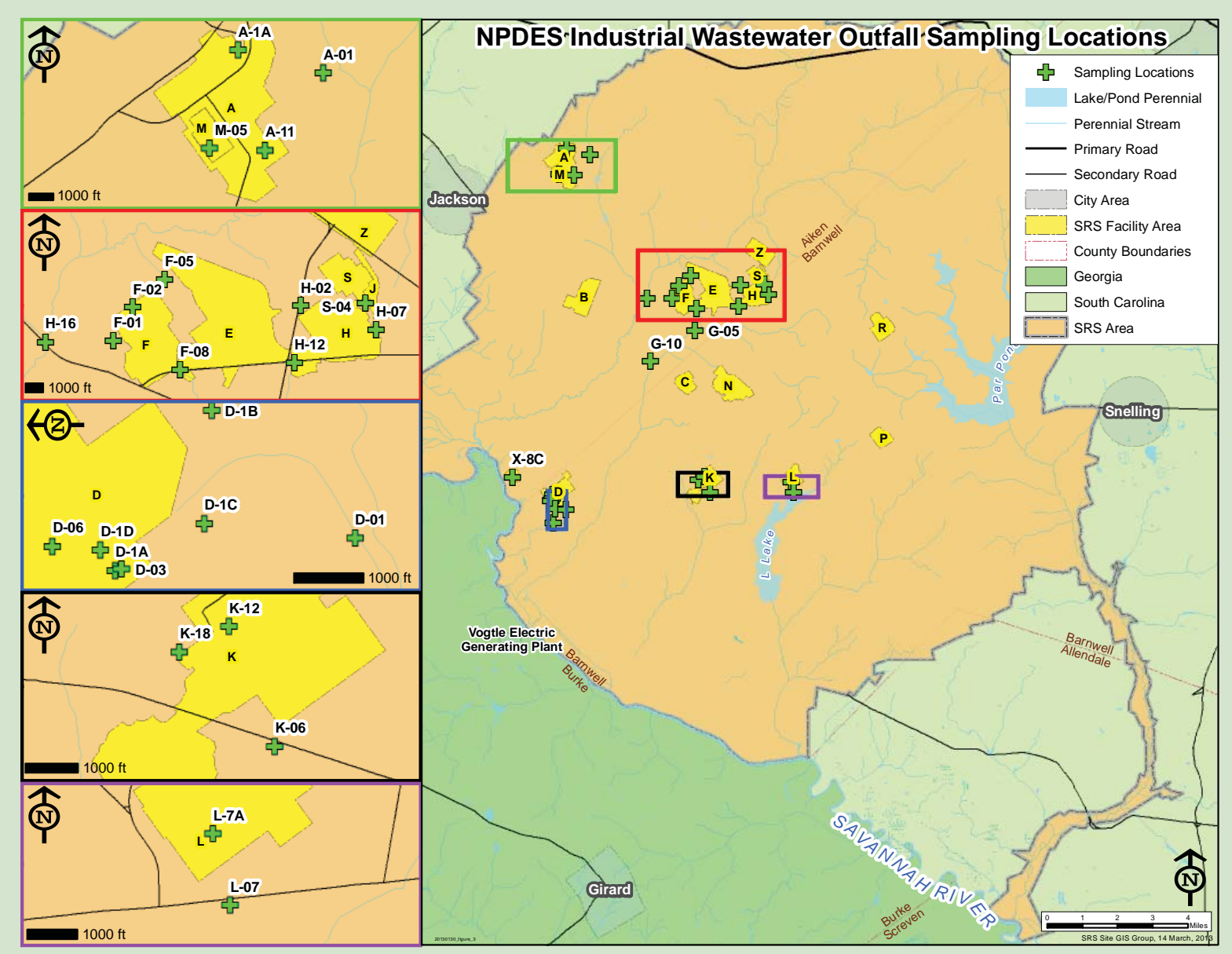

Figure 4-5 NPDES Industrial Wastewater Outfall Sampling Locations

Twenty-nine industrial wastewater outfalls were regulated at SRS in 2012 under NPDES Permits SC0000175, SC0047431, and SC0049107. Of the 29 outfalls, one (Outfall 002) appears in Permit SC0047431 but has never existed - and thus is not included on the map. 


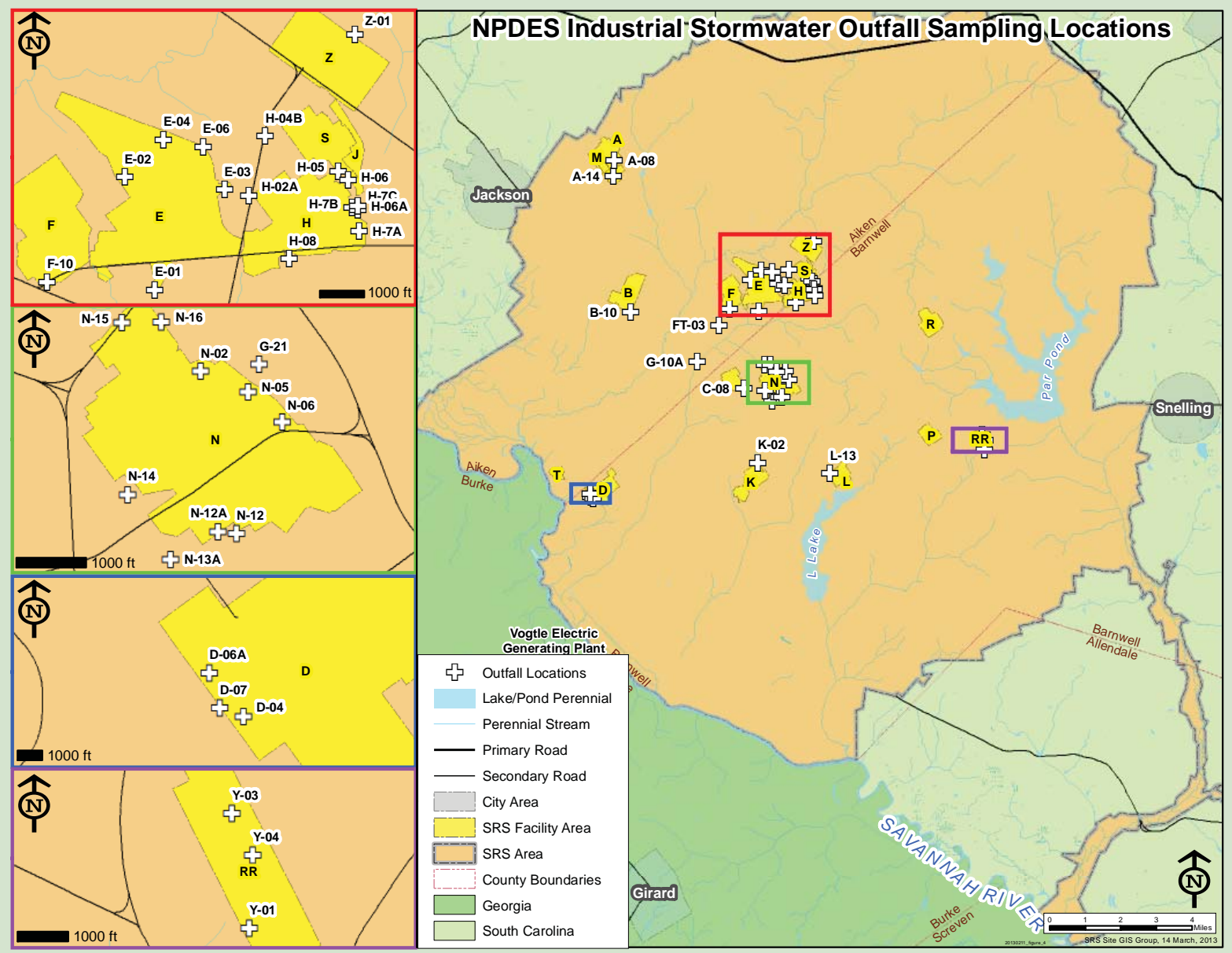

Figure 4-6 NPDES Industrial Stormwater Outfall Sampling Location

Forty industrial stormwater outfalls were regulated at SRS in 2012 under Permit SCR000000, the NPDES General Permit for Stormwater Discharges associated with Industrial Activity (except construction activity).

NPDES samples are collected in the field according to 40 CFR 136 ("Guidelines Establishing Test Procedures for the Analysis of Pollutants"). This document lists specific sample collection, preservation, and analytical methods acceptable for the type of pollutant to be analyzed. Figure 4-7 shows an automated water sampler.

Sludge from the sanitary wastewater treatment facilities is managed under the requirements contained in Permit ND0072125, a no-discharge, land application permit issued by SCDHEC. SRS personnel transfer sludge generated at the sanitary wastewater treatment facilities from the sludge thickener to the drying beds. The air-dried sludge removed from the drying beds is then stored in a shed until land application of the resulting biosolids. No sludge land

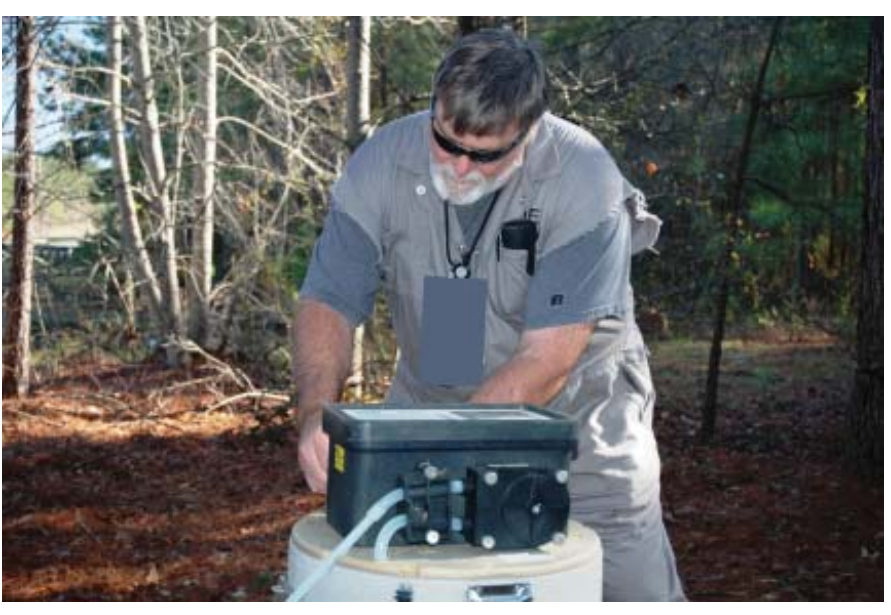

Figure 4-7 An Automated Water Sampler Programmed at an Industrial Wastewater Outfall applications were necessary in 2012. 


\section{Releases Summary}

SRS reports NPDES industrial wastewater analytical results to SCDHEC through monthly discharge monitoring reports (EPA Form 3320-1). Six out of approximately 5,198 sample analyses performed during 2012 exceeded NPDES permit limits, a 99.89\% compliance rate. SRS received one Notice of Violation from SCDHEC for exceedance of copper limits at H-12 outfall; however, SCDHEC did not assess any fines. Chapter 3, "Compliance Summary,” Table 3-3, Summary of SRS NPDES Limit Exceptions in 2012 describes the NPDES exceptions. Data Table 4-8 provides a compilation of industrial wastewater analytical data for 2012.

SRS monitored all industrial stormwater outfalls per the requirements of the permit. Sample results demonstrated compliance with permit limits. Data Table 4-9 provides a compilation of stormwater analytical data for 2012. Stormwater runoff from construction activities does not require sampling unless requested by SCDHEC to address specific discharge issues at a given construction site; SCDHEC did not request such sampling in 2012. Figure 4-8 shows the installation of a stormwater sampling device.

Sampling for general utility water (e.g., non-contact cooling water, steam condensate, boiler blowdown, etc.) was not required in 2012 because all discharges remained under flow thresholds.

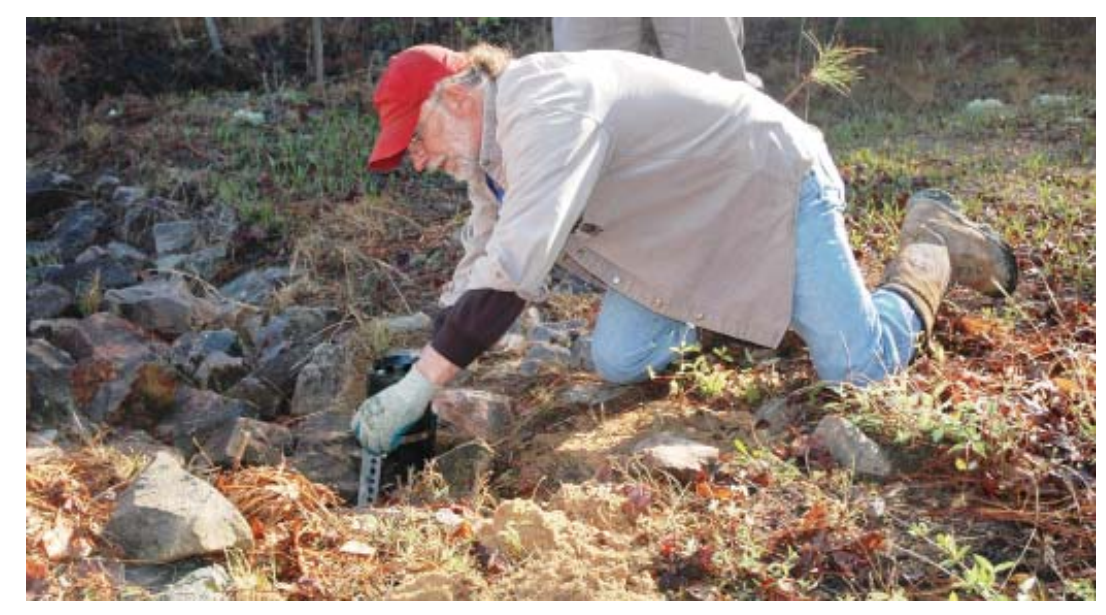

Figure 4-8 Installation of a Stormwater Sampling Device at an Industrial Stormwater Outfall 
This page intentionally left blank. 


\title{
ENVIRONMENTAL SURVEILLANCE
}

\author{
Teresa Eddy \\ John Adams \\ Lori Coward \\ Karen Vangelas \\ Environmental Compliance \& Area Completion Projects \\ Timothy Jannik \\ Savannah River National Laboratory
}

$D$ epartment of Energy (DOE) Order 458.1 "Radiation Protection of the Public and the Environment" establishes the requirements to protect the public and the environment against undue risk from radiation associated with radiological activities conducted under the control of DOE pursuant to the Atomic Energy Act of 1954, as amended. To verify protection of the public and the environment, SRS conducts environmental surveillance activities for potential radiological and nonradiological impacts to air, water, environmental media, and wildlife.

SRS surveys and quantifies the effects that routine and nonroutine operations have on the Site, the surrounding area, and population through its monitoring programs. Environmental surveillance within and beyond the SRS perimeter is performed at designated sampling points representative of the distribution of pathways (liquid and airborne) from facility release locations into the environment.

SRS divides Site surveillance activities into radiological and nonradiological programs. Surveillance monitoring includes the following:

\begin{tabular}{|l|l|}
\hline Radiological Surveillance Monitoring & Nonradiological Surveillance Monitoring \\
\hline Airborne Pathway & Airborne Pathway \\
\hline Air & Rainwater/wet disposition (Chapter 9) \\
\hline Rainwater & Air (Chapter 4) \\
\hline Food products & Liquid Pathway \\
\hline Soil & Surface water \\
\hline Vegetation & Sediment \\
\hline Liquid Pathway & Fish \\
\hline Fish & Drinking water \\
\hline Sediment and settleable solids & \\
\hline Surface water (river, streams) & \\
\hline Drinking water & \\
\hline SRS Deer and Hog Consumption Pathway & \\
\hline Wildlife & \\
\hline
\end{tabular}

SRS conducts environmental monitoring in accordance with DOE Order 458.1, to characterize routine and nonroutine releases of radioactive material from radiological activities, characterize the pathway(s) of exposure to members of the public, and to estimate the doses to individuals and populations in the vicinity of the Site. Evaluation of a variety of surveillance media monitors the pathways of exposure and doses to individuals, nearby populations and the environment. Dose assessment information based on data from this program is presented in Chapter 6, "Radiological Dose Assessments."

Additionally, nonradiological activities are monitored to comply with other federal and state regulations such as the Comprehensive Environmental Response, Compensation and Liability Act (CERCLA), Clean Water Act (CWA), Safe Drinking Water Act, Federal Insecticide, Fungicide, and Rodenticide Act (FIFRA), and South Carolina primary drinking water regulations. In addition, nonradiological data evaluates the impact of Site operations on the environment. 
Table 5-1 summarizes the offsite surveillance sampling that is performed in Georgia and South Carolina excluding samples collected in the Savannah River. Figure 5-1 displays these locations on a map. The water samples, sediment samples, and fish samples collected in the Savannah River are not located on this map. Groundwater monitoring is covered in Chapter 7, "Groundwater."

SRS and other groups monitor the Savannah River, including the South Carolina Department of Health and Environmental Control (SCDHEC), the Georgia Department of Natural Resources, Georgia Power Company's Vogtle Electric Generating Plant (VEGP), which operates in Georgia, the city of Savannah, Georgia, and the Beaufort-Jasper Water and Sewer Authority.

Results of SRS onsite and offsite surveillance monitoring efforts indicate that SRS operations are protective of the public and the environment. This chapter provides details on the monitoring programs noted above and the results for 2012. Throughout the chapter, tables on the CD housed inside the back cover of this report which contains complete data sets ("Environmental Data/Maps - 2012") are denoted in this chapter as "Data Table 5-X." Tables in the chapter itself are referred to simply as "Table 5-X." Also, on the CD are maps showing all applicable sampling locations.

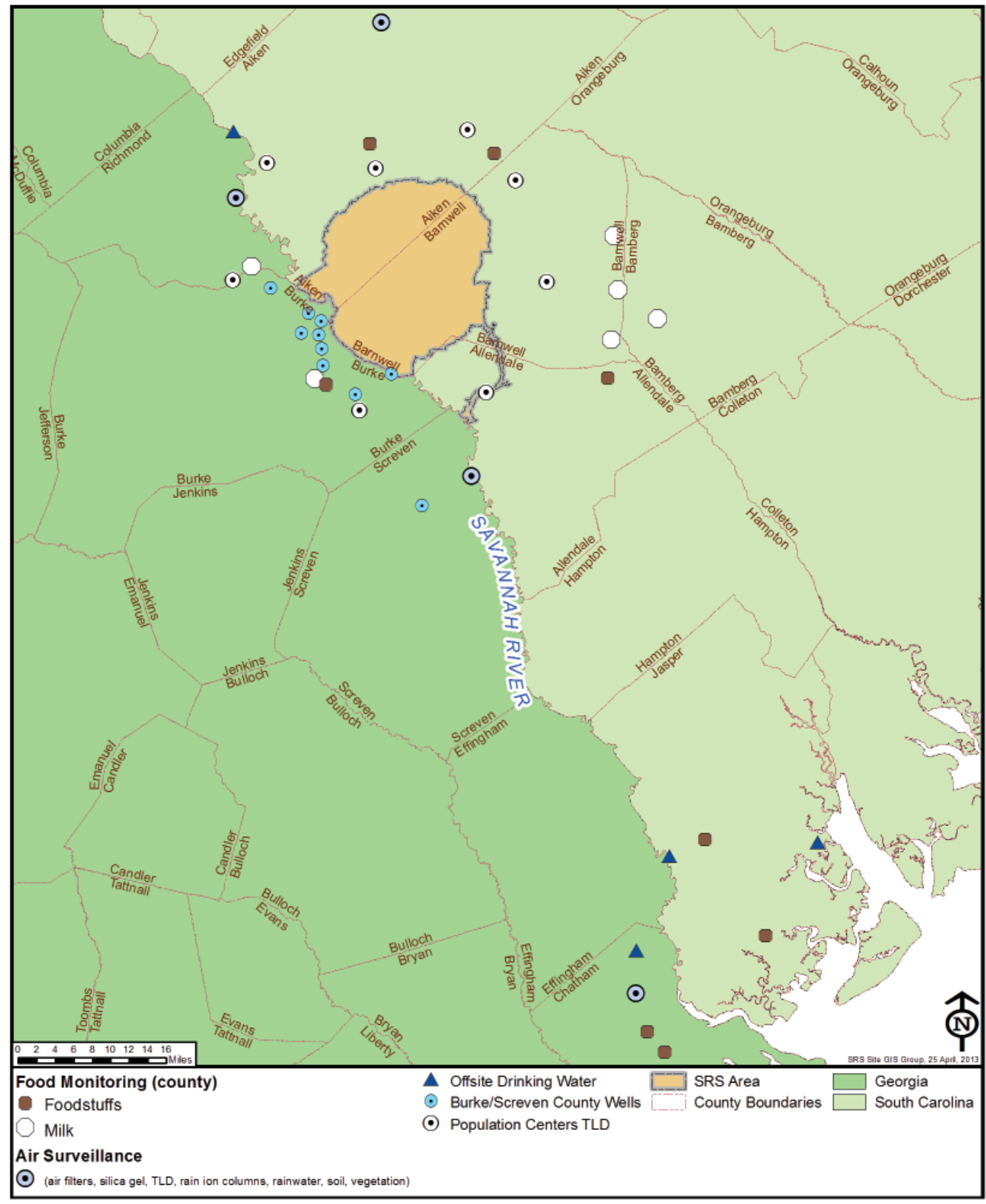

Figure 5-1 SRS Offsite Sampling Media for Georgia and South Carolina 
Table 5-1 Offsite Radiological Annual Sampling Collection and Monitoring Distribution by State

\begin{tabular}{|c|c|c|c|c|}
\hline Environmental Media & $\begin{array}{l}\text { South Carolina } \\
\text { Locations }\end{array}$ & $\begin{array}{l}\text { Georgia } \\
\text { Locations }\end{array}$ & $\begin{array}{c}\text { South Carolina } \\
\text { Approximate } \\
\text { Number of Samples }\end{array}$ & $\begin{array}{c}\text { Georgia } \\
\text { Approximate } \\
\text { Number of } \\
\text { Samples } \\
\end{array}$ \\
\hline \multicolumn{5}{|c|}{ Airborne Exposure Pathway } \\
\hline Air Filters & 1 & 3 & 52 & 156 \\
\hline Silica Gel & 1 & 3 & 26 & 78 \\
\hline $\begin{array}{l}\text { External Ambient Gam- } \\
\text { ma Radiation Monitor- } \\
\text { ing (Thermoluminescent } \\
\text { dosimeters[TLDs]) }\end{array}$ & 7 & 5 & 140 & 100 \\
\hline Rain Ion Columns & 0 & 2 & 0 & 24 \\
\hline Rainwater & 1 & 3 & 12 & 36 \\
\hline Food Products & 5 & 3 & 35 & 21 \\
\hline Milk & 4 & 2 & 16 & 8 \\
\hline Soil & 1 & 3 & 1 & 3 \\
\hline Vegetation (nonedible) & 1 & 3 & 1 & 3 \\
\hline \multicolumn{5}{|c|}{ Liquid Exposure Pathway } \\
\hline Drinking Water & 3 & 1 & 36 & 12 \\
\hline Groundwater & 0 & 10 & 0 & 36 \\
\hline Total & 24 & 38 & 319 & 477 \\
\hline
\end{tabular}

\section{Radiological Monitoring}

SRS conducts routine surveillance of all applicable radiation exposure pathways on all environmental media that could result in a measurable annual dose to the public above background at and beyond the SRS boundary. Radionuclides present in and around the SRS environment are from a number of sources, including (1) natural background, (2) fallout from historical atmospheric testing of nuclear weapons, (3) offsite nuclear power plant operations, and (4) SRS operations.

SRS collects environmental monitoring samples within and beyond the SRS perimeter at designated sampling points representative of the distribution of liquid and airborne pathways to the public and the environment. Table 5-2 summarizes the radiological surveillance sampling media and frequencies.

Offsite surveillance activities include the collection of samples of river water, sediment, milk, food products, fish, air, rainwater, TLDs for ambient gamma exposure monitoring, soil, vegetation, and drinking water. 
Table 5-2 Radiological Surveillance Sampling Frequencies

\begin{tabular}{|c|c|c|c|c|c|c|}
\hline \multicolumn{7}{|c|}{ Radiological Airborne Pathway } \\
\hline \multirow{2}{*}{\multicolumn{2}{|c|}{ Media }} & \multicolumn{5}{|c|}{ Sampling Frequency } \\
\hline & & Weekly & Bi-Weekly & Monthly & Quarterly & Annual \\
\hline \multirow{5}{*}{ Air } & $\begin{array}{c}\text { Airborne particulate } \\
\text { matter }\end{array}$ & & $\checkmark$ & & & \\
\hline & $\begin{array}{c}\text { Gaseous state of radio- } \\
\text { iodine }\end{array}$ & & $\checkmark$ & & & \\
\hline & Tritiated water vapor & & $\checkmark$ & & & \\
\hline & Tritium in rainwater & & & $\checkmark$ & & \\
\hline & Wet/Dry deposition & & & $\checkmark$ & & \\
\hline Soil & $\begin{array}{l}\text { Airborne pathway for } \\
\text { radioactive deposition } \\
\text { into the environment }\end{array}$ & & & & & $\checkmark$ \\
\hline $\begin{array}{c}\text { Food Prod- } \\
\text { ucts (Collards, } \\
\text { Meats, Fruit) } \\
\end{array}$ & $\begin{array}{l}\text { Radiological contami- } \\
\text { nants in the food chain }\end{array}$ & & & & & $\checkmark$ \\
\hline Vegetation & $\begin{array}{l}\text { Monitor for trends in } \\
\text { radionuclide mobility } \\
\text { and uptake by plants }\end{array}$ & & & & & $\checkmark$ \\
\hline TLDs & $\begin{array}{l}\text { Ambient gamma radia- } \\
\text { tion monitoring }\end{array}$ & & & & $\checkmark$ & \\
\hline \multicolumn{7}{|c|}{ Radiological Liquid Pathway } \\
\hline \multirow{2}{*}{\multicolumn{2}{|c|}{ Media }} & \multicolumn{5}{|c|}{ Sampling Frequency } \\
\hline & & Weekly & Bi-Weekly & Monthly & Quarterly & Annual \\
\hline \multirow{4}{*}{ Water } & Onsite drinking water & & & & $\checkmark$ & $\checkmark$ \\
\hline & Offsite drinking water & & & $\sqrt{ }$ & $\sqrt{ }$ & $\sqrt{ }$ \\
\hline & $\begin{array}{l}\text { Onsite surface water } \\
\text { (streams and basins) }\end{array}$ & $\begin{array}{c}\checkmark \\
\text { (based on } \\
\text { location) } \\
\end{array}$ & $\begin{array}{c}\checkmark \\
\text { (based on } \\
\text { location) } \\
\end{array}$ & $\begin{array}{c}\checkmark \\
\text { (based on } \\
\text { location) } \\
\end{array}$ & & $\begin{array}{c}\checkmark \\
\text { (based on } \\
\text { location) } \\
\end{array}$ \\
\hline & Savannah River & $\checkmark$ & & & & $\checkmark$ \\
\hline Sediment & $\begin{array}{l}\text { Measures the move- } \\
\text { ment, deposition, and } \\
\text { accumulation of long- } \\
\text { lived radionuclides in } \\
\text { streambeds and in the } \\
\text { Savannah River bed }\end{array}$ & & & & & $\checkmark$ \\
\hline \multirow[t]{2}{*}{$\begin{array}{l}\text { Fish and } \\
\text { Shellfish }\end{array}$} & $\begin{array}{l}\text { Bass, catfish, bream, } \\
\text { mullet, redfish, sea } \\
\text { trout } \\
\end{array}$ & & & & & $\sqrt{ }$ \\
\hline & Oysters & & & & & $\checkmark$ \\
\hline Wildlife & $\begin{array}{l}\text { Field and lab moni- } \\
\text { toring of onsite deer, } \\
\text { feral hogs, turkey, and } \\
\text { coyotes during Site } \\
\text { sponsored controlled } \\
\text { hunts }\end{array}$ & & & & & $\sqrt{ }$ \\
\hline
\end{tabular}




\section{Atmospheric Surveillance}

SRS conducts atmospheric monitoring both onsite and offsite to determine whether airborne radionuclides from SRS releases have reached the environment in measurable quantities. SRS performs air monitoring to estimate the dose and remain in compliance with the $10 \mathrm{mrem} /$ year dose limit specified in DOE Order 458.1. The atmospheric surveillance program monitors both air and rainwater.

SRS maintains a network of 15 atmospheric surveillance sampling stations in and around SRS to monitor the concentration of tritium and radioactive particulate matter in the air and rainwater. Tritium is the most abundant airborne radionuclide released as part of routine SRS operations, and it becomes part of the natural environment. The tritiumin-air surveillance results validate the dose models utilized in determining the dose from SRS atmospheric releases.

The surveillance stations are placed at the center of SRS, around the Site perimeter, in population centers 25 and 100 miles from SRS, and at a control location (assumed to be unimpacted by SRS operations) nearly 25 miles from SRS. SRS has placed monitoring stations on the Site boundary to ensure that at least one monitoring station is in every 45-degree sector to be representative of the atmospheric distribution of airborne releases into the environment. Each atmospheric surveillance sampling station consists of the components listed in Table 5-3.

Table 5-3 Atmospheric Surveillance Stations

\begin{tabular}{|c|c|c|c|}
\hline Media & Purpose & Analytes & Data Table \\
\hline $\begin{array}{l}\text { Glass-Fiber } \\
\text { Filter }\end{array}$ & $\begin{array}{l}\text { Airborne } \\
\text { Particulate } \\
\text { Matter }\end{array}$ & $\begin{array}{l}\text { Gamma-emitting radionuclides, gross alpha/beta } \\
\text { emitting radionuclides }\end{array}$ & $5-1$ \\
\hline $\begin{array}{l}\text { Charcoal } \\
\text { Canister }\end{array}$ & $\begin{array}{l}\text { Gaseous } \\
\text { States of } \\
\text { Radioiodine }\end{array}$ & $\begin{array}{l}\text { Iodine-129, Iodine-131, gamma-emitting radionu- } \\
\text { clides }\end{array}$ & $5-2$ \\
\hline Silica Gel & $\begin{array}{l}\text { Tritiated } \\
\text { Water Vapor }\end{array}$ & Tritium & $5-3$ \\
\hline Rainwater & $\begin{array}{l}\text { Tritium in } \\
\text { Rainwater }\end{array}$ & Tritium & $5-5$ \\
\hline $\begin{array}{l}\text { Rain Ion } \\
\text { Column }\end{array}$ & $\begin{array}{l}\text { Wet/Dry } \\
\text { Deposition }\end{array}$ & $\begin{array}{l}\text { Gamma-emitting radionuclides, gross alpha/beta } \\
\text { emitting radionuclides, total strontium, actinides } \\
\text { (plutonium, americium, uranium, curium, and } \\
\text { neptunium) }\end{array}$ & $5-4$ \\
\hline
\end{tabular}

Analytes listed in Table 5-3 are determined by SRS airborne releases that are expected from the airborne exposure pathway from SRS. Radionuclides can be alpha emitting, beta emitting, or gamma emitting. Background levels in the atmosphere consist of either naturally occurring radionuclides (i.e. uranium, thorium, and radon), as well as, radionuclides (i.e. strontium-90, cesium-137) from global fallout (settling or captured by raindrops) due to historical nuclear weapons testing.

The atmosphere contains radionuclides in various forms (gaseous, particulate matter, water vapor). In addition, rainwater can redeposit particulate matter from the air onto the ground that can eventually be absorbed into vegetation or soil. Therefore, wet/dry deposition monitoring as a pathway to exposure is included in the atmospheric surveillance program. 


\section{Atmospheric Monitoring Results Summary}

\section{Gross Alpha and Beta-emitting Radionuclides}

Gross alpha and beta results provide useful information for trending of the total activity in screening samples; however, these results cannot provide concentrations of specific radionuclides. If the gross analytical results appear to be elevated, then immediate analyses for specific radionuclides may be performed to investigate a potential problem, such as an unplanned release. Concentrations are compared to applicable Derived Concentration Standards (DCS) for the public as outlined in DOE Order 458.1. Average gross alpha results for 2012 were comparable to 2011 and the previous five years.

\section{Gamma-emitting Radionuclides}

Cesium-137, a gamma-emitting radionuclide, enters the atmosphere at quantities well below the DCS. Air filter and charcoal canister results for 2012 indicated no detectable amounts of the man-made gamma-emitting radionuclides cesium-137 or cobalt- 60 , which is consistent with the historical results.

\section{Alpha-emitting Radionuclides-Actinides}

During 2012, detectable levels of uranium-234 and uranium-238 were present in $86 \%$ and $93 \%$ of the filter samples respectively; however, no detectable levels of uranium-235 were observed in any of the 2012 samples. These results are similar to those observed in 2011 and in previous years. Uranium is naturally occurring in soil, and therefore expected to be present in low concentrations on air filters. Aside from uranium, the only alpha-emitting radionuclide observed was americium-241 in 2 of 15 air filter samples. Generally, these concentrations were consistent with historical results. All other alpha-emitting isotopes were insignificant or below method detection limits.

\section{Iodine-129, Iodine-131}

Analytical results indicated no detectable levels of iodine-129 and iodine-131 in samples collected in 2012.

\section{Tritium-in-Air}

Tritium-in-air results for 2012 were generally lower than those observed in 2011 and the previous five years consistent with the long-term statistical variability (Table 5-4). Tritium-in-air results showed detectable levels in 100 of the 393 (25\%) silica gel samples for 2012. As in previous years, the Burial Ground North (BGN) location showed average and maximum concentrations significantly higher than those observed at other locations. BGN concentrations are higher and more variable because of the location's proximity to both the tritium facilities and to the phytoremediation project near the center of SRS and therefore, influenced by operations at these facilities. As expected, tritium concentrations generally decreased with increasing distance from the tritium facilities, as reflected in results from BGN compared to results from the Site perimeter and beyond the perimeter (Table 5-4). Figure 5-2 shows a SRS employee reading an atmospheric surveillance sampling station. 
Table 5-4 2012 Average Tritium-in-Air Results (pCi/m³), 2008-2012

\begin{tabular}{|c|c|c|c|c|c|c|}
\hline Location & Location & 2012 & 2011 & 2010 & 2009 & 2008 \\
\hline Onsite (Center) & $\begin{array}{l}\text { Burial Ground } \\
\text { North, SC }\end{array}$ & 172 & 190 & 170 & 233 & 200 \\
\hline $\begin{array}{l}\text { Site Perimeter } \\
\text { (Northwest) }\end{array}$ & Green Pond, SC & 5.79 & 7.49 & 6.49 & 7.90 & 11.5 \\
\hline Site Perimeter & Talatha Gate, SC & 8.98 & 9.93 & 8.15 & 8.71 & 13.3 \\
\hline $\begin{array}{l}\text { Site Perimeter } \\
\text { (North) }\end{array}$ & East Talatha, SC & 4.25 & 8.09 & 6.61 & 5.36 & 10.2 \\
\hline $\begin{array}{l}\text { Site Perimeter } \\
\text { (Northeast) }\end{array}$ & Darkhorse, SC & 5.83 & 8.63 & 6.91 & 6.30 & 27.2 \\
\hline Site Perimeter (East) & Highway 21/167, SC & 5.25 & 7.47 & 8.48 & 7.03 & 13.2 \\
\hline Site Perimeter (East) & Barnwell Gate, SC & 4.93 & 6.30 & 7.11 & 9.04 & 16.4 \\
\hline $\begin{array}{l}\text { Site Perimeter } \\
\text { (Southeast) }\end{array}$ & $\begin{array}{l}\text { Patterson Mill Road, } \\
\text { SC }\end{array}$ & 4.91 & 4.81 & 5.09 & 5.97 & 8.43 \\
\hline Site Perimeter (South) & Allendale Gate, SC & 4.47 & 4.86 & 4.93 & 5.26 & 7.45 \\
\hline $\begin{array}{l}\text { Site Perimeter } \\
\text { Southwest) }\end{array}$ & D-Area, SC & 7.00 & 12.6 & 7.91 & 15.3 & 14.7 \\
\hline Site Perimeter (West) & Jackson, SC & 6.17 & 9.01 & 7.59 & 6.88 & 8.26 \\
\hline $\begin{array}{l}\text { 25-miles from SRS } \\
\text { (Northwest) }\end{array}$ & Augusta, GA & 3.82 & 5.27 & 2.03 & 3.83 & 14.1 \\
\hline $\begin{array}{l}\text { 25-miles from SRS } \\
\text { (North) }\end{array}$ & Aiken Airport, SC & 5.55 & 7.71 & 3.77 & 6.60 & 8.44 \\
\hline $\begin{array}{l}\text { 25-miles from SRS } \\
\text { (South) }\end{array}$ & $\begin{array}{l}\text { Highway 301, GA } \\
\text { (CONTROL) }\end{array}$ & 7.76 & 5.28 & 2.99 & 3.29 & 5.18 \\
\hline $\begin{array}{l}\text { 100-miles from SRS } \\
\text { (Southeast) }\end{array}$ & $\begin{array}{l}\text { Savannah, GA } \\
\text { (CONTROL) }\end{array}$ & 3.03 & 3.86 & 2.86 & 3.34 & 5.24 \\
\hline
\end{tabular}

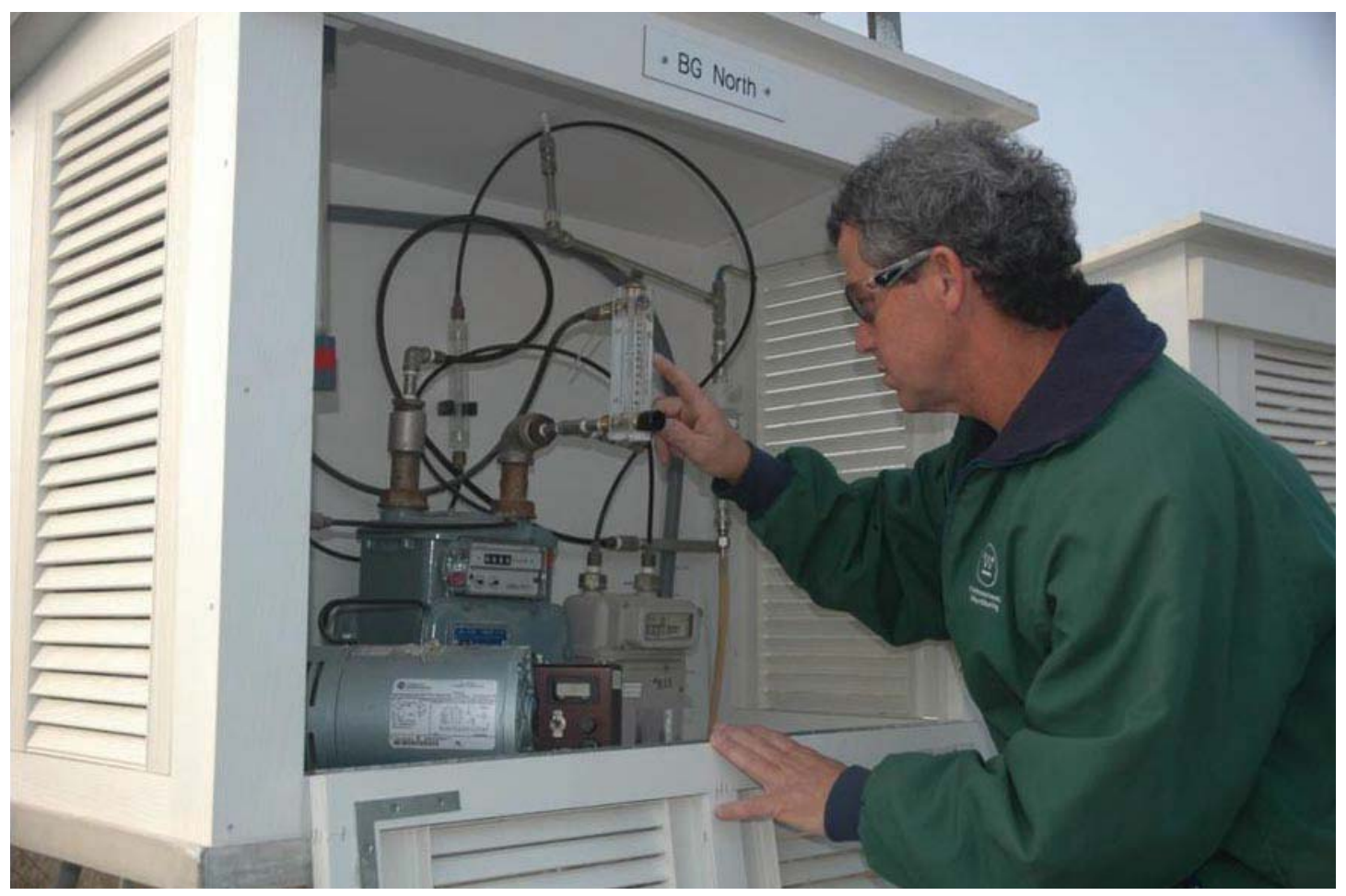

Figure 5-2 Environmental Monitoring Field Technician Reads Air Flow at the Burial Ground North Air Surveillance Station 


\section{Rainwater Monitoring Results}

\section{Tritium-in-Rainwater}

Tritium-in-rainwater results showed detectable levels in 24 of the 194 (12\%) rainwater samples for 2012 with levels similar or lower than 2011 and the previous five years. Levels are below the EPA drinking standard of 20,000 pCi/L. As in previous years, tritium-in-rain values were highest near the center of the SRS with a decreasing trend moving away from the Site (Table 5-5).

Table 5-5 2012 Tritium-in-Rainwater Results (pCi/L)

\begin{tabular}{|c|c|c|c|c|}
\hline Location & Location & Average & Maximum & Percent $>$ MDC \\
\hline Onsite (Center) & $\begin{array}{l}\text { Burial Ground North, } \\
\text { SC }\end{array}$ & 3,010 & 6,350 & 100 \\
\hline $\begin{array}{l}\begin{array}{l}\text { Site Perimeter } \\
\text { (Northwest) }\end{array} \\
\end{array}$ & Green Pond, SC & 106 & 265 & 0 \\
\hline Site Perimeter (North) & Talatha Gate, SC & 229 & 500 & 31 \\
\hline Site Perimeter (North) & East Talatha, SC & 172 & 422 & 8 \\
\hline $\begin{array}{l}\begin{array}{l}\text { Site Perimeter } \\
\text { (Northeast) }\end{array} \\
\end{array}$ & Darkhorse, SC & 186 & 878 & 8 \\
\hline Site Perimeter (East) & Highway $21 / 167, \mathrm{SC}$ & 176 & 624 & 15 \\
\hline Site Perimeter (South) & Barnwell Gate, SC & 148 & 332 & 0 \\
\hline $\begin{array}{l}\text { Site Perimeter } \\
\text { (Southeast) }\end{array}$ & $\begin{array}{l}\text { Patterson Mill Road, } \\
\text { SC }\end{array}$ & 170 & 768 & 8 \\
\hline Site Perimeter (South) & Allendale Gate, SC & 113 & 332 & 0 \\
\hline $\begin{array}{l}\begin{array}{l}\text { Site Perimeter } \\
\text { (Southwest) }\end{array} \\
\end{array}$ & D-Area, SC & 185 & 454 & 15 \\
\hline Site Perimeter (West) & Jackson, SC & 140 & 405 & 8 \\
\hline $\begin{array}{l}\text { 25-miles from SRS } \\
\text { (Northwest) }\end{array}$ & Augusta, GA & 108 & 249 & 0 \\
\hline $\begin{array}{l}\text { 25-miles from SRS } \\
\text { (North) }\end{array}$ & Aiken Airport, SC & 92 & 286 & 0 \\
\hline $\begin{array}{l}\text { 25-miles from SRS } \\
\text { (South) }\end{array}$ & $\begin{array}{l}\begin{array}{l}\text { Highway 301, GA } \\
\text { (CONTROL) }\end{array} \\
\end{array}$ & 62 & 224 & 0 \\
\hline $\begin{array}{l}\text { 100-miles from SRS } \\
\text { (Southeast) }\end{array}$ & \begin{tabular}{|l}
$\begin{array}{l}\text { Savannah, GA } \\
\text { (CONTROL) }\end{array}$ \\
\end{tabular} & 53 & 281 & 0 \\
\hline
\end{tabular}

\section{Gross Alpha and Beta Emitting Radionuclides}

Gross alpha and gross beta results from 2012 were consistent with those of 2011 and previous five-year historical trend levels. Levels are below the EPA drinking water risk level for potential health effects from long-term exposure. Results in wet/dry deposition from rainfall ranged from below the minimum detectable concentration (MDC) to a maximum of $10.2 \mathrm{pCi}$ per square meter gross alpha and a maximum of $231 \mathrm{pCi}$ per square meter gross beta.

\section{Gamma-emitting Radionuclides}

No detectable levels of man-made gamma-emitting radionuclides were observed in rainwater samples during 2012.

\section{Alpha-Emitting Radionuclides-Actinides}

Detectable levels of uranium-234 and uranium-238 were present in $26 \%$ and $21 \%$ of the wet/dry deposition samples, respectively. However, no detectable levels of uranium-235 were in any of the 90 samples. Uranium is naturally occurring in soil; and thus, is expected to be present at low concentrations in deposition samples. Americium-241 was observed in $10 \%$ of the 90 samples (three from the BGN location, five at the site perimeter, and one at the 25-mile control location). The average concentration of americium-241 was well below the EPA drinking water standard. 


\section{Strontium}

A total of eight strontium-89, 90 results were above the MDC (seven at the center of the SRS and one at the D Area perimeter location). The strontium concentration levels were below the EPA drinking water risk level for potential health effects from long-term exposure.

\section{Ambient Gamma Monitoring}

Ambient external exposure from gamma radiation is measured using TLDs. An extensive network of dosimeters in and around SRS is used to monitor external ambient gamma exposure rates. SRS uses TLDs to quantify integrated gamma exposure which is the external exposure from gamma radiation accumulated over a period of time from multiple TLD readings. The TLD performs this function accurately, reliably, and relatively inexpensively. Figure 5-3 shows TLDs at a monitoring station.

SRS has been monitoring ambient environmental gamma exposure rates with TLDs since 1965 to determine the impact (if any) of Site operations on the gamma exposure in the environment and to evaluate trends in environmental exposure levels. Other uses include support of routine and emergency response dose calculations.

The SRS ambient gamma radiation monitoring program has four subprograms: Site perimeter stations, population centers, air surveillance stations, and Vogtle (stations that monitor exposures from Georgia Power's VEGP). Most gamma exposure monitoring is conducted onsite and at the SRS perimeter. SRS conducts offsite monitoring in population centers within nearly nine miles $(15 \mathrm{~km})$ of the Site boundary, but only limited monitoring beyond this distance and at the 25 and $100 \mathrm{mi} \mathrm{(40} \mathrm{and} 160 \mathrm{~km}$ ) air surveillance stations.

\section{Results Summary}

Ambient gamma exposure rates at all TLD monitoring locations show some variation based on normal site-to-site and year-to-year differences in the components of natural ambient gamma radiation exposure levels. In 2012, ambient gamma exposure rates varied between $61.6 \mathrm{mrem} / \mathrm{yr}$ (location NRC_2 in South Carolina) and $118 \mathrm{mrem} / \mathrm{yr}$ (location Beech Island, South Carolina) (Data Table 5-6).

Ambient gamma results are consistent with previously published historical results and indicate that no significant difference in average annual dose rates exists between monitoring networks except in the case of population centers. Ambient dose rates in population centers are slightly elevated compared to the other monitoring networks, as expected, because of higher natural background radiation levels emitted from materials present in buildings and roadways.

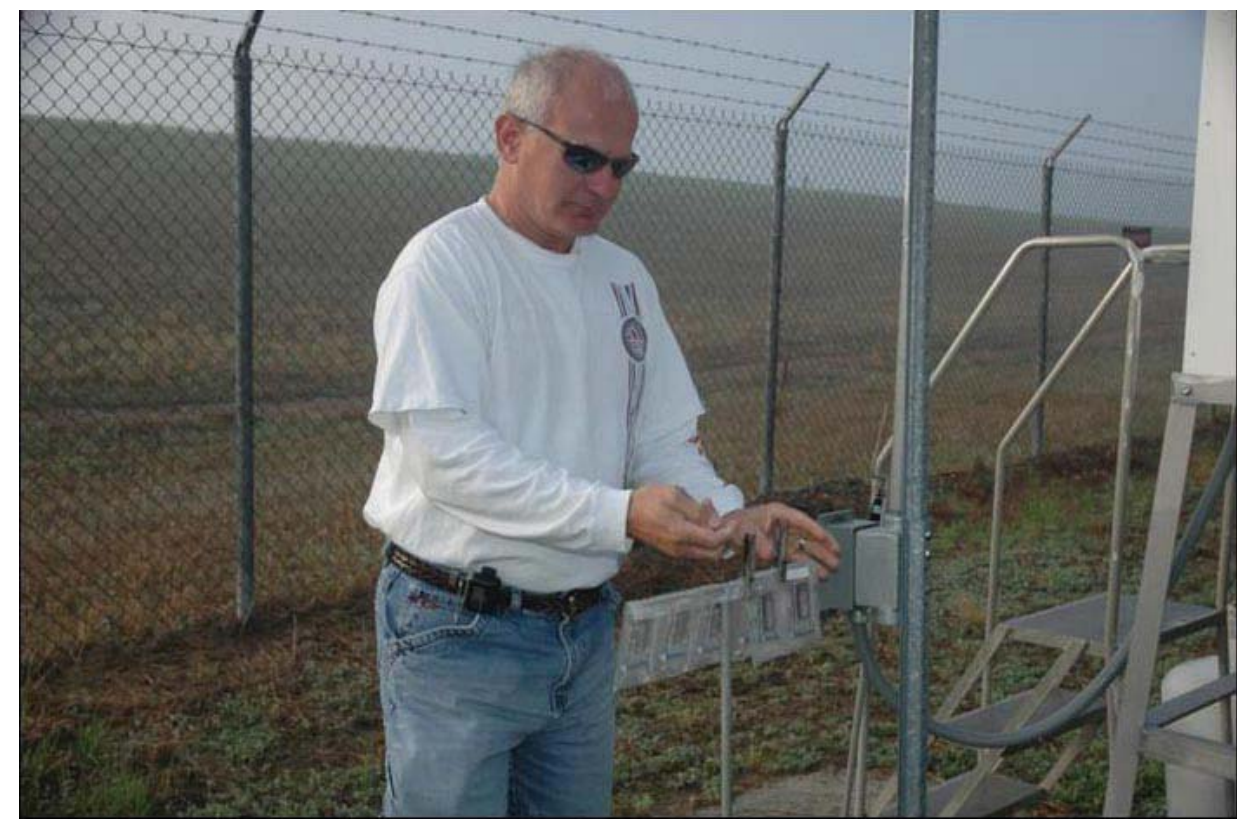

Figure 5-3 An Environmental Monitoring Field Technician Removes TLDs from the Burial Ground North Air Station 


\section{Stormwater Basin Monitoring}

SRS monitors stormwater accumulating in the Site's stormwater basins for gross alpha, gross beta, tritium, strontium, gamma-emitting radionuclides, and actinides. There are no active processes discharging to stormwater basins onsite, hence the accumulations in the stormwater basins are determined to be primarily rainwater runoff. Monitoring for specific radionuclides occurs where previous operational history indicates the possible presence of certain radionuclides. The E-Area basins receive stormwater from the Solid Waste Disposal Facility (SWDF), E-Area Vault, and stormwater from the controlled clean-soil pit on the east side of E Area. F-Area Pond 400 receives stormwater from F Area and the Mixed Oxide Fuel Fabrication Facility. Z-Area Basin receives stormwater from Z Area.

In 2012, monitoring was conducted at five E-Area basins as well as at the Z-Area Basin and F-Area Pond 400.

\section{Results Summary}

Gross alpha, beta, and tritium results for the SRS stormwater basins are summarized in Table 5-6 below. Other than the Z-Area Basin, the concentrations were comparable to those of the previous five years (Data Table 5-7). The highest maximum tritium concentration was observed at the E-03 Basin, at 31,900 (+/-610) pCi/L, higher than the 20,000 pCi/L EPA drinking water maximum contaminant level (MCL), but consistent with the previous five years of historical results. In addition, this basin does not actively discharge to the environment. Except for the Z-Area Basin, no other basin samples showed detectable levels of man-made gamma-emitting radionuclides. Fission products, as well as some actinides, were observed in the basins measuring a mean average of less than $1.00 \mathrm{pCi} / \mathrm{L}$.

Z-Area basin results are summarized in Table 5-7 below. These concentrations resulted from stormwater runoff from the nearby Saltstone Disposal Facility (SDF) Vault 4. Although levels are higher than in 2011 and the historical trend, they are below the DOE DCS for cesium-137, technetium-99, and EPA screening levels for strontium-89, 90. SRS performed special sampling outside the basin and at McQueen's Branch to determine if the increasing levels had migrated into the environment downstream of the basin. Results indicated that no downstream transport occurred since all water results outside of the basin were below the MDC. The Z-Area Basin is designed for a 25-year flood event and does not actively discharge to the environment. SDF management implemented steps for radioactive contamination control (i.e., installation of weather enclosures, enhanced facility operations, and installation of stormwater management controls). SDF operations and radiological control maintains radiological areas in accordance with SRS radiological practices.

Table 5-6 Average Gross Alpha, Gross Beta, and Tritium Summary for Stormwater Basins

\begin{tabular}{|c|c|c|c|c|}
\hline $\begin{array}{c}\text { Basin } \\
\text { Location }\end{array}$ & $\begin{array}{c}\text { Average Gross } \\
\text { Alpha } \\
\text { (pCi/L) }\end{array}$ & $\begin{array}{c}\text { Average Gross Beta } \\
\text { (pCi/L) }\end{array}$ & $\begin{array}{c}\text { Average } \\
\text { Tritium (pCi/L) }\end{array}$ & $\begin{array}{c}\text { Maximum } \\
\text { Tritium (pCi/L) }\end{array}$ \\
\hline E-01 & 0.440 & 4.11 & 3,410 & 4,970 \\
\hline E-02 & 0.834 & 7.44 & 15,000 & 25,200 \\
\hline E-03 & 1.20 & 3.59 & 9,430 & 31,900 \\
\hline E-04 & 0.816 & 3.21 & 7,220 & 14,300 \\
\hline E-05 & 1.79 & 5.29 & 14,400 & 27,300 \\
\hline Pond 400 & 1.73 & 7.08 & 646 & 1,680 \\
\hline Z-Area & 1.53 & 365 & 1,490 & 3,050 \\
\hline
\end{tabular}

Table 5-7 Radionuclides in Z-Area Basin

\begin{tabular}{|c|c|c|}
\hline Radionuclide & Average (pCi/L) & Maximum (pCi/L) \\
\hline Cs-137 & 489 & 1,300 \\
\hline Tc-99 & 11.8 & 28.9 \\
\hline Sr-89, 90 & 0.778 & 1.18 \\
\hline U-238 & 0.068 & 0.125 \\
\hline U-234 & 0.067 & 0.171 \\
\hline Tritium & 1,490 & 3,050 \\
\hline
\end{tabular}




\section{SRS Stream Monitoring}

SRS conducts continuous surveillance of SRS streams downstream of several process areas to detect and quantify levels of radioactivity transported to the Savannah River by effluents and shallow groundwater migration. The five primary streams are Upper Three Runs, Fourmile Branch, Pen Branch, Steel Creek, and Lower Three Runs (Figure 5-4). The frequency and types of analyses reflect the upstream discharges and/or groundwater migration history of radionuclides. Figure 5-5 shows an automated stream sampling location.

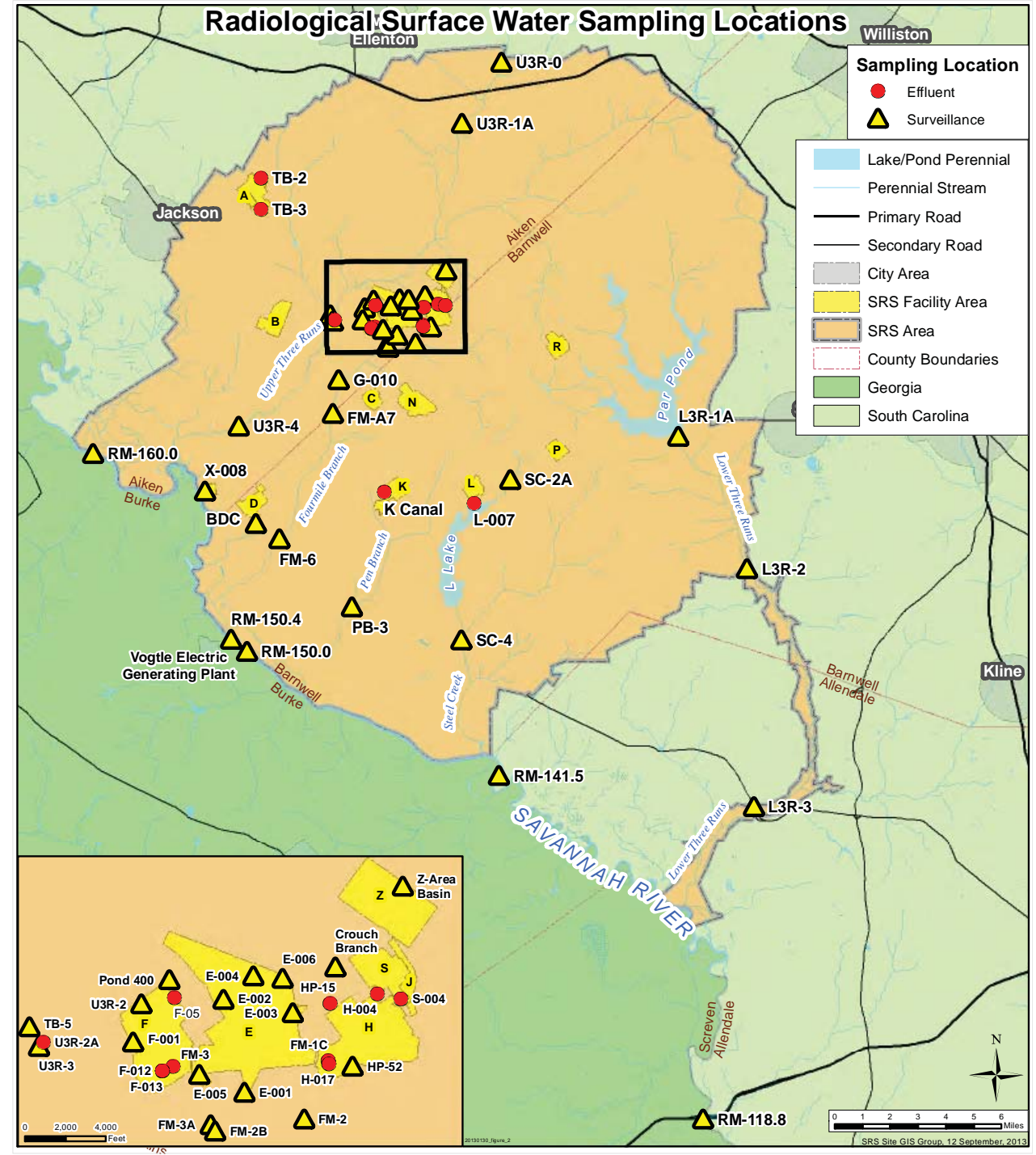

Figure 5-4 Radiological Surface Water Sampling Locations

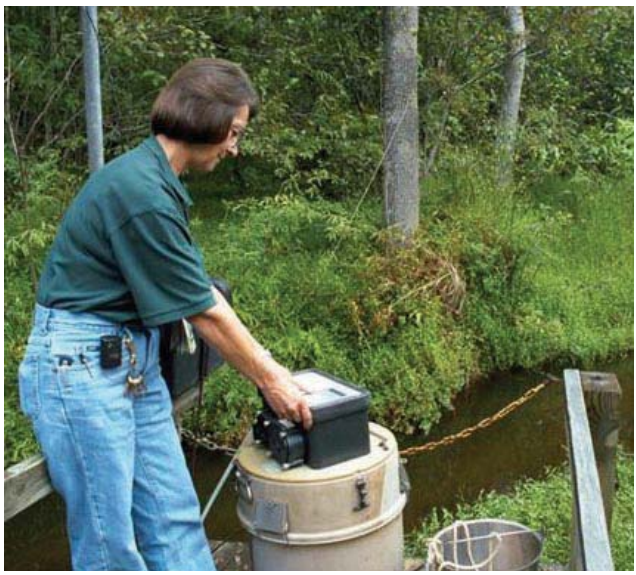

Figure 5-5 Maintenance Being Performed on an Automated Sampler at One of the Stream Sampling Locations 


\section{Results Summary}

Table 5-8 presents the average 2012 concentrations of gross alpha, gross beta, and tritium in SRS streams. All of the results are included in Data Table 5-8. SRS found detectable concentrations of tritium, the predominant radionuclide detected above background levels in SRS streams, at least once at all stream locations in 2012. When comparing stream tritium averages for 2012 and 2011, all were either slightly lower or within the statistical standard deviation of the previous five years. The ten-year trend chart for the average tritium levels in the streams shows a decreasing trend (Figures 5-6 and 5-7), which is due to a combination of decreases in Site releases and the natural decay of tritium. Figures 5-6 and 5-7 indicate that tritium levels in locations Pen Branch-3, Fourmile Branch-6, and Steel Creek-4 are trending closer to the EPA drinking water standard of 20,000 pCi/L, and Upper Three Runs-4 and Lower Three Runs-3 are below the drinking water standard.

Table 5-8 Average 2012 Concentration of Radioactivity in SRS Stream Locations Prior to Entry into Savannah River

\begin{tabular}{|l|c|c|c|}
\hline \multicolumn{1}{|c|}{ Location } & $\begin{array}{c}\text { Average Gross } \\
\text { Alpha (pCi/L) }\end{array}$ & $\begin{array}{c}\text { Average Gross } \\
\text { Beta (pCi/L) }\end{array}$ & $\begin{array}{c}\text { Average } \\
\text { Tritium (pCi/L) }\end{array}$ \\
\hline \multicolumn{4}{|c|}{ Onsite Stream Locations } \\
\hline Tims Branch (TB-5) & 5.39 & 2.60 & 446 \\
\hline Lower Three Runs (L3R-3) & 2.42 & 2.41 & 575 \\
\hline Steel Creek (SC-4) & 0.570 & 1.21 & 2,250 \\
\hline Pen Branch (PB-3) & 0.687 & 1.04 & 28,500 \\
\hline Fourmile Branch (FM-6) & 0.478 & 6.06 & 43,600 \\
\hline Upper Three Runs (U3R-4) & 8.90 & 3.95 & 774 \\
\hline \multicolumn{1}{|c|}{ Onsite Control Locations (for comparison purposes) } \\
\hline Upper Three Runs (U3R-1A) & 29.4 & 11.3 & 225 \\
\hline Upper Three Runs (0) & 5.32 & 2.24 & 267 \\
\hline
\end{tabular}

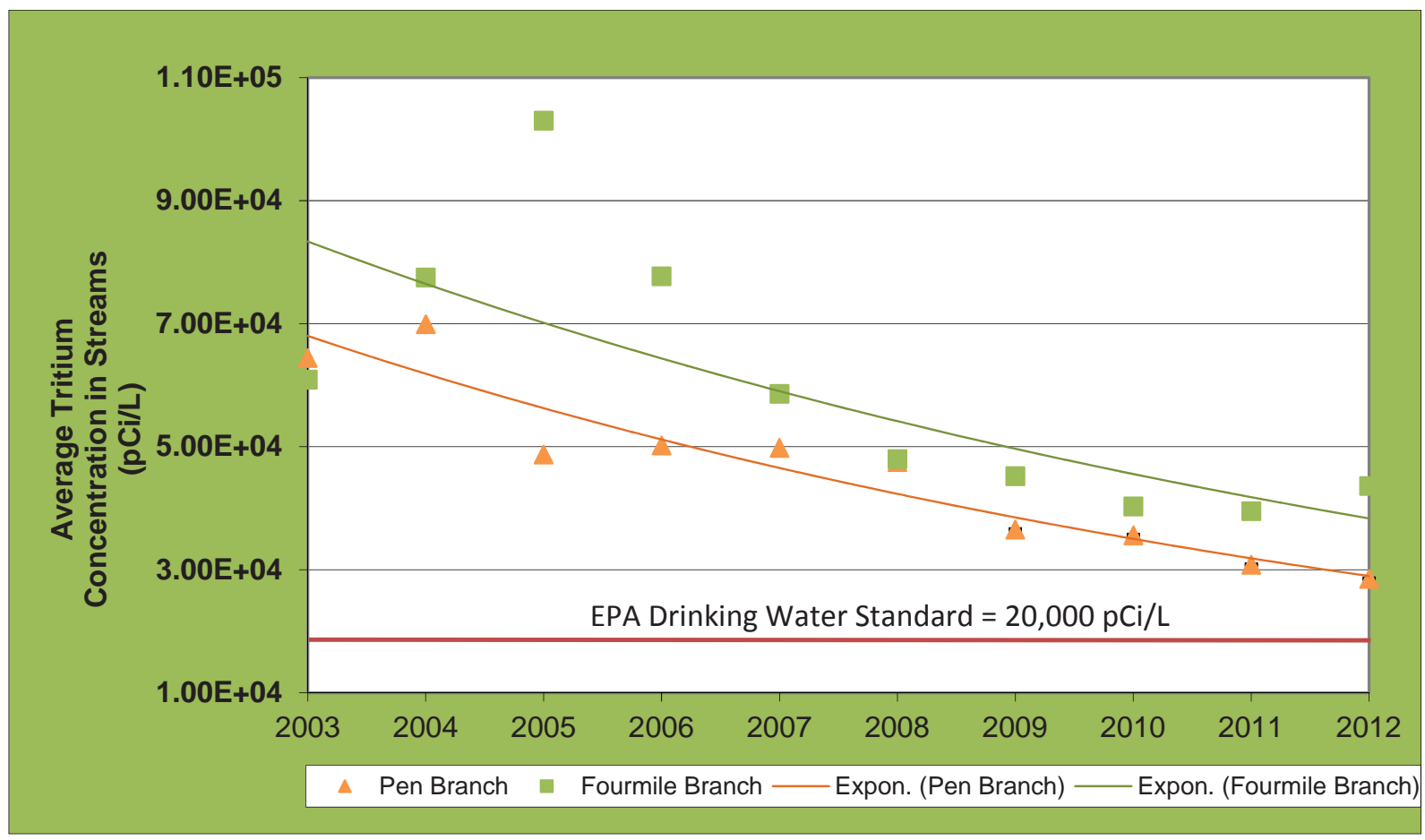

Figure 5-6 Ten-Year Trend of Average Tritium Concentration in Locations Pen Branch-3 and Fourmile Branch-6 (pCi/L) 


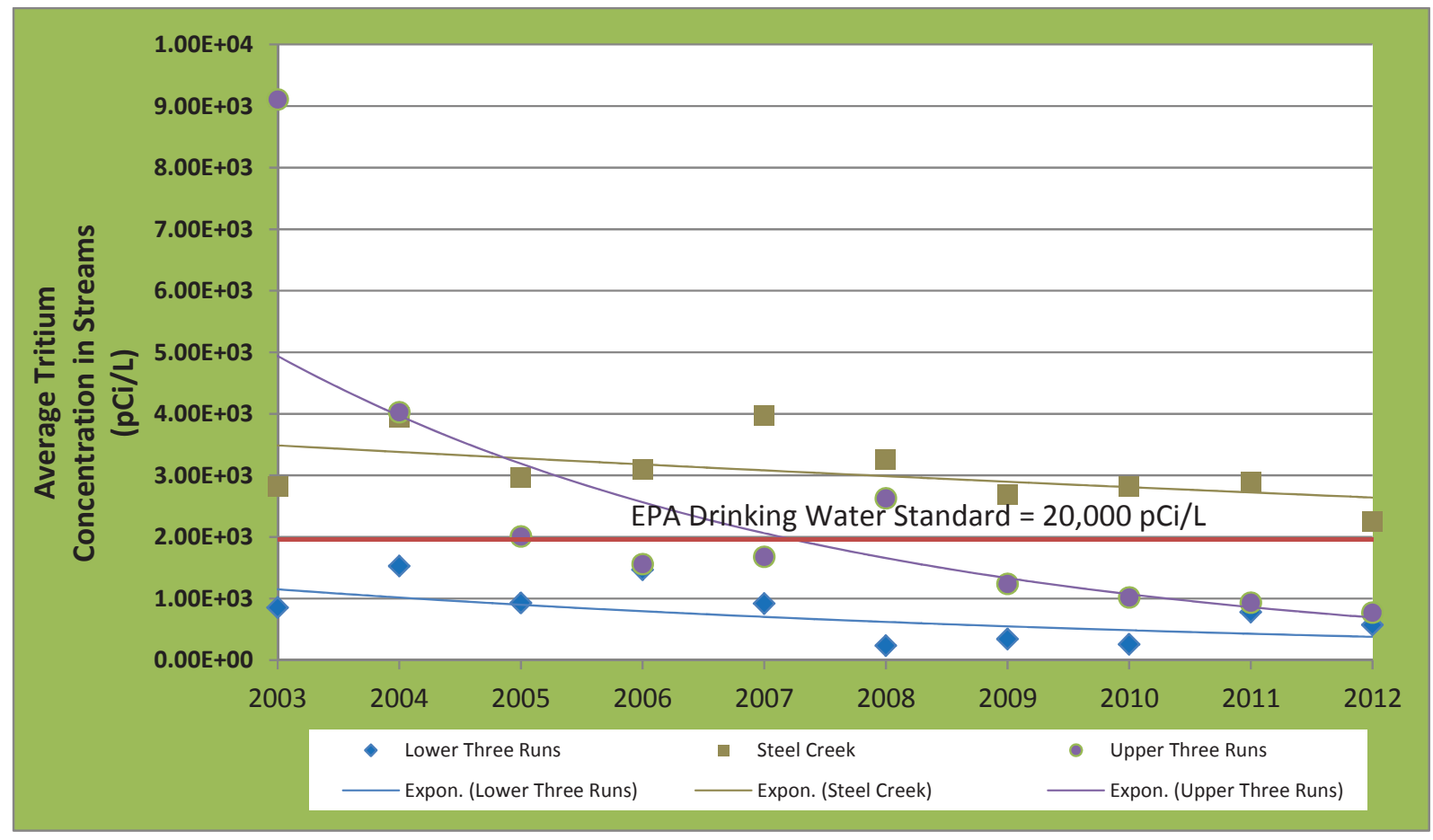

Figure 5-7 Ten-Year Trend of Average Tritium Concentrations in Lower Three Runs-3, Steel Creek-4, and Upper Three Runs-4 (pCi/L)

Cesium-137 was detected in 13 of 256 stream samples (5\%) for 2012 from the Fourmile Branch locations. Gross alpha and gross beta activity was detected in all SRS streams, but overall average concentrations were consistent with levels of recent years. Because gross alpha levels were higher than the EPA recommended gross screening level at which to perform isotopic analyses on some of the Upper Three Runs locations, isotopic analyses were conducted and revealed the source to be natural uranium. The levels are included in the radioactivity transport calculations. Strontium-89, 90 was detected in all samples from the Fourmile Branch locations with an average of $3.29(+/-0.143) \mathrm{pCi} / \mathrm{L}$ and a maximum of $7.84(+/-0.48)$, below the $\mathrm{MCL}$ of $8 \mathrm{pCi} / \mathrm{L}$. Other radionuclides were observed at locations throughout SRS but were consistent with the source of the material and exhibited variations similar to those of previous years. No significant trends were observed in 2012 when compared with recent years, and, in most cases, averages were less than $1 \mathrm{pCi} / \mathrm{L}$.

\section{Seepage Basin and Solid Waste Disposal Facility (SWDF) Radionuclide Migration Monitoring}

To incorporate the migration of radioactivity to SRS streams into total radioactive release quantities, SRS personnel monitor and quantify the migration of radioactivity from SRS seepage basins and the SWDF as part of its stream surveillance program. Seepage basins include the General Separations Area (F and H Area) Seepage Basins and K-Area Seepage Basin, which have been closed.

Radioactivity previously deposited in the F-Area and H-Area Seepage Basins and SWDF continues to migrate through the groundwater and to outcrop into Fourmile Branch and Upper Three Runs. Groundwater migration from the F-Area Seepage Basins enters Fourmile Branch among locations FM-3A, FM-2B, and FM-A7. Migration from the SWDF is not distinguishable from a part of H-Area Seepage Basin 4 because of their close proximity in location. K-Area Seepage Basin migrates into Pen Branch.

\section{Results Summary}

Migration releases into Fourmile Branch, Upper Three Runs, and Pen Branch are summarized in Data Table 5-9. Tritium, strontium-89, 90, technetium-99, iodine-129, and cesium-137 were detected in migration releases (Data Table $5-9)$. 
Figure 5-8 is a graphical representation of releases of tritium via migration to Site streams from 2003 through 2012. As seen in the figure, migration releases of tritium generally have declined the past 10 years, with year-to-year variability caused mainly by the amount of annual rainfall. Accordingly, during 2012, the total quantity of tritium migrating from SRS seepage basins and SWDF into SRS streams was $650 \mathrm{Ci}$ compared to $803 \mathrm{Ci}$ in 2011, an 18\% decrease (Table 5-9).

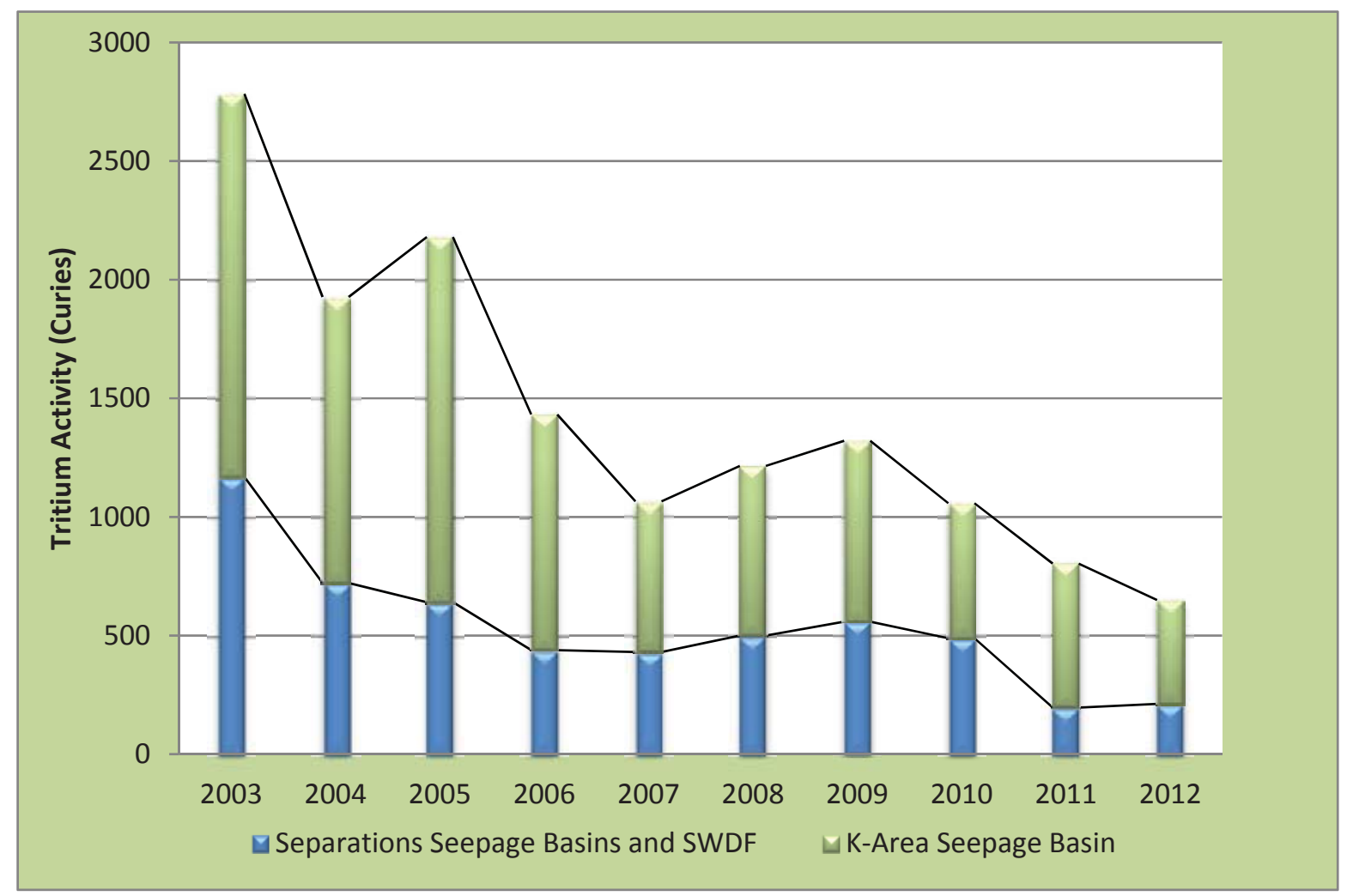

Figure 5-8 Estimated Tritium Migration from SRS Seepage Basins and SWDF to SRS Streams, 2003 - 2012

Table 5-9 Tritium Migration Total (Curies) From SRS Seepage Basins and SWDF

\begin{tabular}{|c|c|c|c|}
\hline Year & K-Area Seepage Basin & Separations Seepage Basins and SWDF & Total Ci \\
\hline $\mathbf{2 0 0 2}$ & 1,030 & 977 & 2,007 \\
\hline $\mathbf{2 0 0 3}$ & 1,170 & 1,613 & 2,783 \\
\hline $\mathbf{2 0 0 4}$ & 722 & 1,205 & 1,927 \\
\hline $\mathbf{2 0 0 5}$ & 641 & 1,539 & 2,180 \\
\hline $\mathbf{2 0 0 6}$ & 439 & 993 & 1,432 \\
\hline $\mathbf{2 0 0 7}$ & 431 & 635 & 1,066 \\
\hline $\mathbf{2 0 0 8}$ & 500 & 715 & 1,215 \\
\hline $\mathbf{2 0 0 9}$ & 559 & 762 & 1,321 \\
\hline $\mathbf{2 0 1 0}$ & 489 & 569 & 1,058 \\
\hline $\mathbf{2 0 1 1}$ & 197 & 606 & 803 \\
\hline $\mathbf{2 0 1 2}$ & 212 & 438 & 650 \\
\hline
\end{tabular}


Of the $650 \mathrm{Ci}$ of tritium migrating into SRS streams, $368 \mathrm{Ci}$ were measured in Fourmile Branch (Table 5-10). The total amount of strontium-89, 90 entering Fourmile Branch from the General Separations Area (GSA) seepage basins and SWDF during 2012 was $0.015 \mathrm{Ci}$ (Table 5-10). Migration releases of strontium-89, 90 vary from year-to-year but have remained below $100 \mathrm{mCi}$ the past nine years. The summary of radionuclide migration into Fourmile Branch is included in Table 5-10.

Table 5-10 Migration into Fourmile Branch - Estimates, Total (Curies)

\begin{tabular}{|l|c|c|}
\hline \multirow{2}{*}{ Radionuclide } & \multicolumn{2}{c|}{ Year } \\
\cline { 2 - 3 } & $\mathbf{2 0 1 2}$ & $\mathbf{2 0 1 1}$ \\
\hline Tritium & 368 & 538 \\
\hline Strontium-89, 90 & 0.015 & 0.015 \\
\hline Technetium-99 & 0.011 & 0.011 \\
\hline Iodine-129 & 0.013 & 0.015 \\
\hline Cesium-137 & 0.046 & 0.02 \\
\hline
\end{tabular}

In order to reduce the tritium flux to Fourmile Branch, SRS conducts phytoremediation activities. Phytoremediation is the direct use of plants to clean up contamination, such as tritium, from soil and water. Using natural processes, plants can break down, trap and hold, or transpire (release to the atmosphere in a modified form) contaminants.

In late 2000, a phytoremediation project was started to manage the tritiated water. A sheet-pile dam was constructed to capture the water from springs prior to release to Fourmile Branch. The captured water is irrigated on to the forest to cause transfer of the water to the atmosphere. The transfer takes place by 1) wetted surface evaporation, and 2) evapotranspiration via the vegetation in the forest. Approximately $90 \%$ of the irrigated water is transferred to the atmosphere via this process. The tritium in water vapor in the atmosphere is rapidly dispersed and represents no significant dose to the facility workers or offsite residents. This project has been very effective, reducing the tritium flux to Fourmile Branch by about $65 \%$.

In 2005, subsurface barriers were completed at the F- and H-Area Seepage Basins to help control tritium releases to Fourmile Branch. In 2008, the capping of the Old Radioactive Waste Burial Ground was completed. Since the implementation of these activities, the tritium migration into Fourmile Branch has decreased (Figure 5-9) and is predicted to fall below the EPA drinking water standard of $20,000 \mathrm{pCi} / \mathrm{L}$ by the year 2042 .

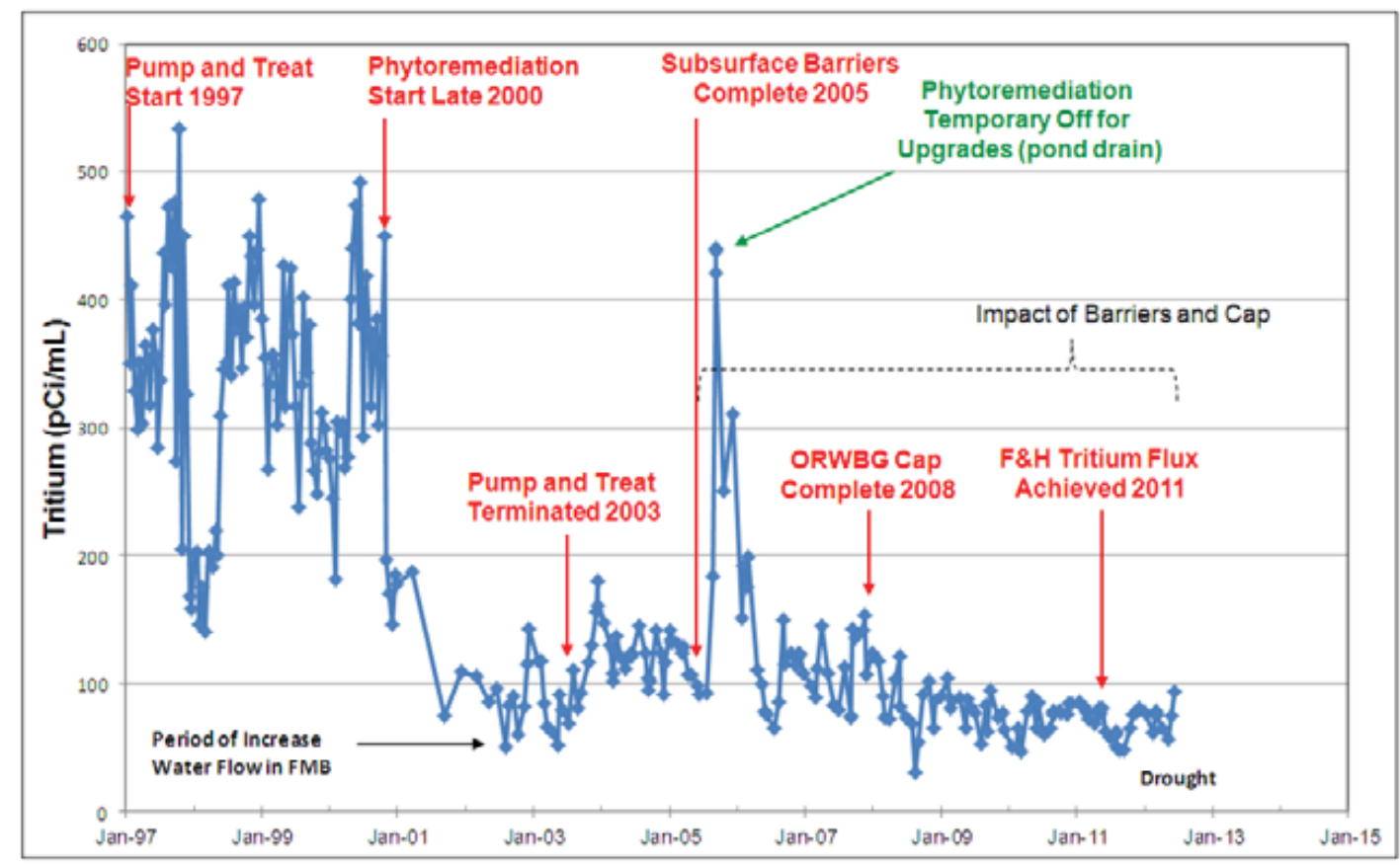

Figure 5-9 Tritium Concentrations in Fourmile Branch, 1997 - 2012 
SRS estimated tritium migration from the north side of SWDF and the GSA into Upper Three Runs in 2012 was 69.9 $\mathrm{Ci}$, compared with the $68.3 \mathrm{Ci}$ in 2011, a fluctuation consistent with historical results. (The GSA is in the central part of SRS and contains all waste disposal facilities, chemical separations facilities, and associated high-level waste storage facilities along with numerous other sources of radioactive material.)

Sampling in Pen Branch measures the tritium migration from the seepage basin and the percolation field below the K-Area Retention Basin. The 2012 estimated migration of $212 \mathrm{Ci}$ compares close to the $197 \mathrm{Ci}$ recorded in 2011.

Stream transport accounts for tritium migration releases from C-Area, L-Area, and P-Area Disassembly Basins (see "Tritium Transport in Streams" section of this chapter).

SRS streams are measured for alpha specific isotopes such as the actinides (uranium, plutonium, americium, and curium) when gross alpha results are greater than the EPA screening levels of $15 \mathrm{pCi} / \mathrm{L}$ gross alpha. This is performed to evaluate and characterize potential radionuclide migration into the streams. Overall, values for 2012 were consistent with historical data and generally remained at or below the analytical MDC.

In order to determine the discharge volumes used for the radioactivity release estimates, flow monitoring is performed at each effluent outfall and stream location. SRS personnel measure area-velocity flows at various frequencies in SRS streams and effluent outfalls for either confirmation of calibration settings of ultrasonic flowmeters or used directly for determination of discharge volumes in estimating the transport of radionuclides into the environment (Figure 5-10).

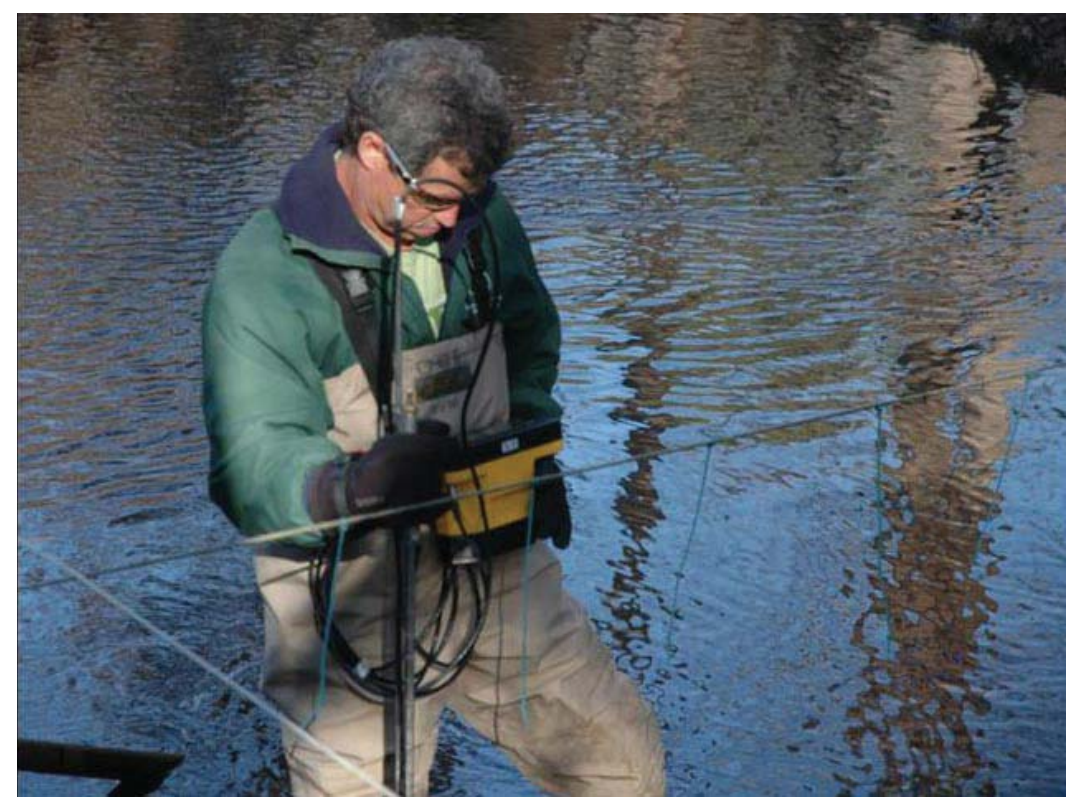

Figure 5-10 Environmental Monitoring Field Technician Performs Area Velocity Measurements across a SRS Stream 


\section{Savannah River Monitoring}

Continuous surveillance monitoring occurs along the Savannah River at locations above and below SRS tributaries, including a location at which liquid discharges from VEGP enter the river.

\section{Results Summary}

Five locations along the river continued to serve as environmental surveillance points in 2012. Composite samples are collected at these five river locations and analyzed for gross alpha, gross beta, tritium, and gamma-emitting radionuclides (Data Table 5-10). The average 2012 concentrations of gross alpha, gross beta, and tritium at river locations are in Table 5-11. The tritium concentration levels are well below the EPA drinking water standard of 20,000 pCi/L.

Table 5-11 Average 2012 Concentrations of Radioactivity in the Savannah River

\begin{tabular}{|l|c|c|c|}
\hline \multicolumn{1}{|c|}{ Location } & $\begin{array}{c}\text { Average Gross Alpha } \\
\text { (pCi/L) }\end{array}$ & $\begin{array}{c}\text { Average Gross Beta } \\
\text { (pCi/L) }\end{array}$ & $\begin{array}{c}\text { Average Tritium } \\
\text { (pCi/L) }\end{array}$ \\
\hline RM-160 (CONTROL) & 0.336 & 2.40 & 156 \\
\hline RM-150.4 (VEGP) & 0.462 & 2.62 & 1,710 \\
\hline RM-150 & 0.332 & 2.26 & 464 \\
\hline RM-141.5 & 0.379 & 2.38 & 596 \\
\hline RM-118.8 & 0.372 & 2.27 & 603 \\
\hline
\end{tabular}

In 2012, detectable levels of gross alpha were present in $4 \%$ and gross beta in $79 \%$ of the 250 samples at levels consistent with the averages of the previous five years. Gross alpha and beta results were below the EPA screening levels requiring additional radionuclide specific analyses. Cesium-137 was not detected in any of the 250 weekly composite river samples for 2012 .

Based on curies released, tritium is the predominant radionuclide detected above background levels in the Savannah River. The combined SRS and VEGP tritium estimates based on concentration results and average flow rates at Savannah River Mile (RM) 118.8 were 1,874 Ci in 2012 compared to 2,090 $\mathrm{Ci}$ in 2011, which are well within the statistical overlap. In addition to the composite samples referenced above, SRS collects annual grab samples to provide a more comprehensive suite of radionuclides (strontium-89, 90, technetium-99, and actinides). Uranium-234, uranium-238, and americium-241 were analyzed in all grab samples from RM 118.8 and several other locations in 2012. Results were consistent with the averages of the previous five years. Figure 5-11 shows sample collection on the Savannah River.

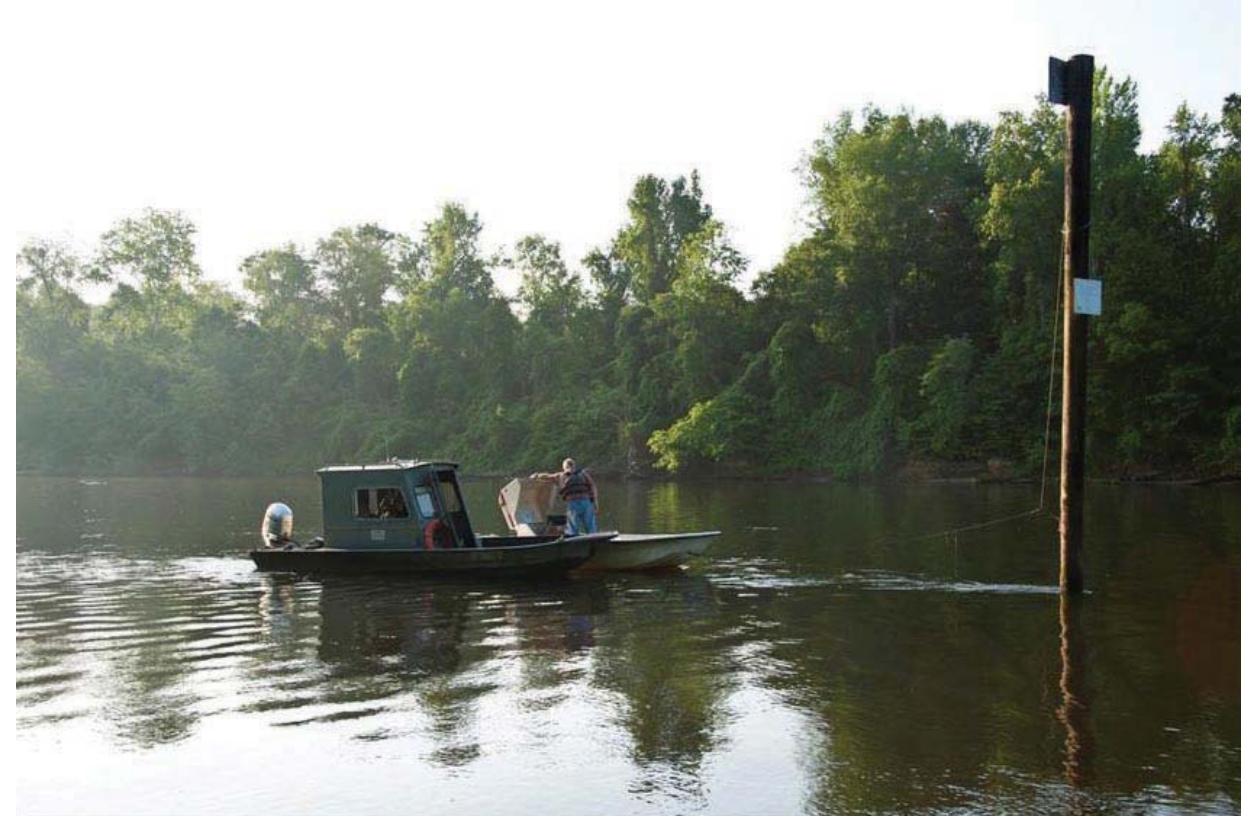

Figure 5-11 Savannah River Surveillance Sample Collection at River Mile 160 


\section{Tritium Transport in Streams and Savannah River Monitoring}

SRS production areas introduce tritium into SRS streams and the Savannah River. Because of the mobility of tritium in water and the quantities of the radionuclide released during the years of SRS operations, SRS performs a tritium balance comparison at various SRS stream and Savannah River monitoring locations. SRS tritium transport data from 1960-2012 (Figure 5-12), shows the history of direct releases, stream transport, and river transport, as determined by SRS personnel. The history of tritium transport at SRS is included in Data Table 5-11. The ten-year trend analysis shows a decreasing trend for the past ten years (Figure 5-13). The tritium balance compares the following methods of calculation:

- Total direct tritium releases, including releases from (1) facility effluent discharges and (2) measured shallow groundwater migration of tritium from SRS seepage basins and SWDF (direct releases).

- Tritium transport in SRS streams, measured at the last sampling point before entry into the Savannah River (stream transport); and

- Tritium transport in the Savannah River, measured downriver of SRS (near RM 118.8) after subtraction of any measured contribution above the SRS (river transport).

The general trend over time is attributable to (1) variations in tritium production and processing at the SRS; (2) the implementation of effluent controls, such as seepage basins, beginning in the early 1960s; and (3) the continuing depletion and decay of the SRS's tritium inventory.

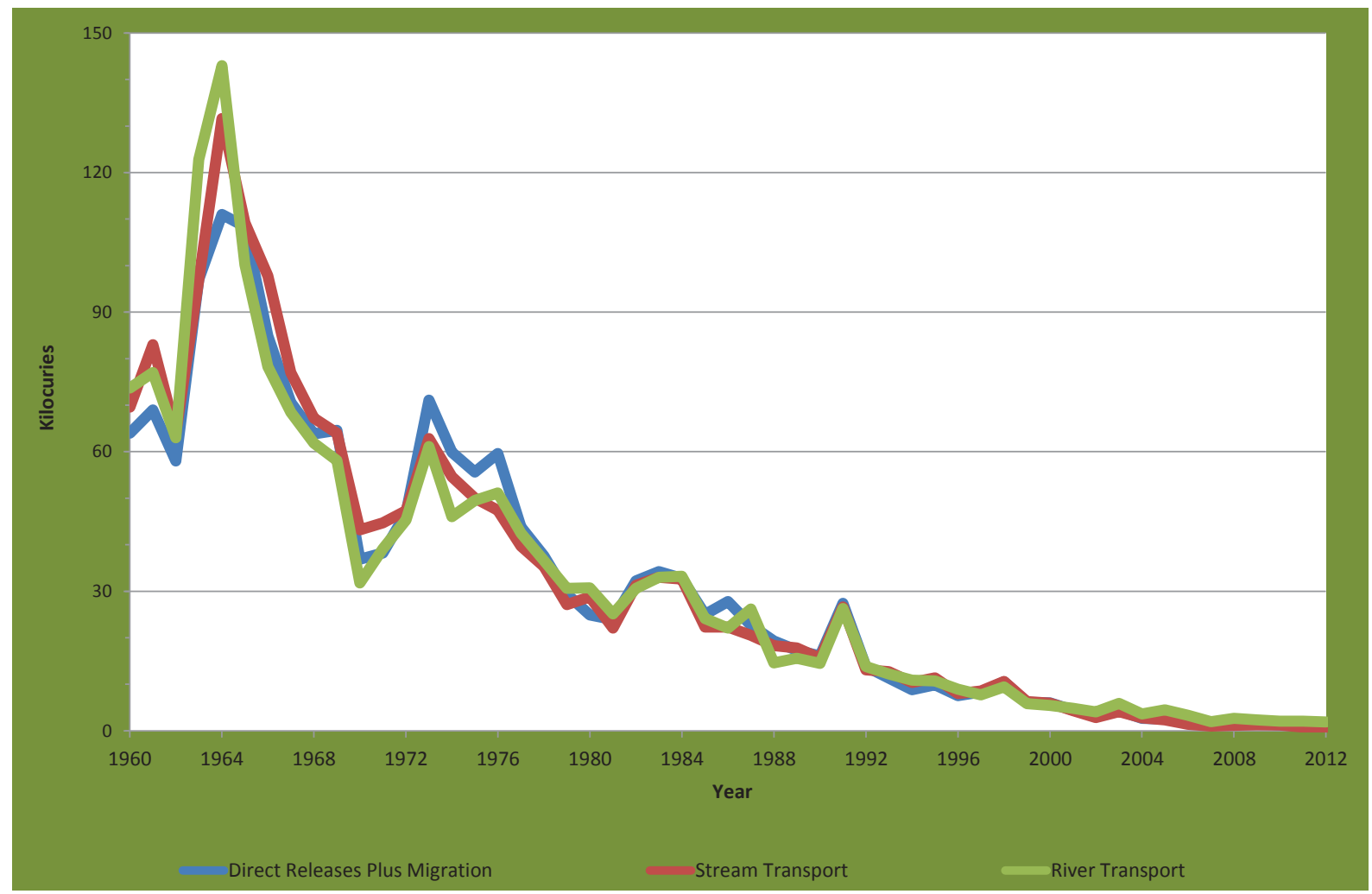

Figure 5-12 SRS Tritium Transport Summary, 1960 - 2012 


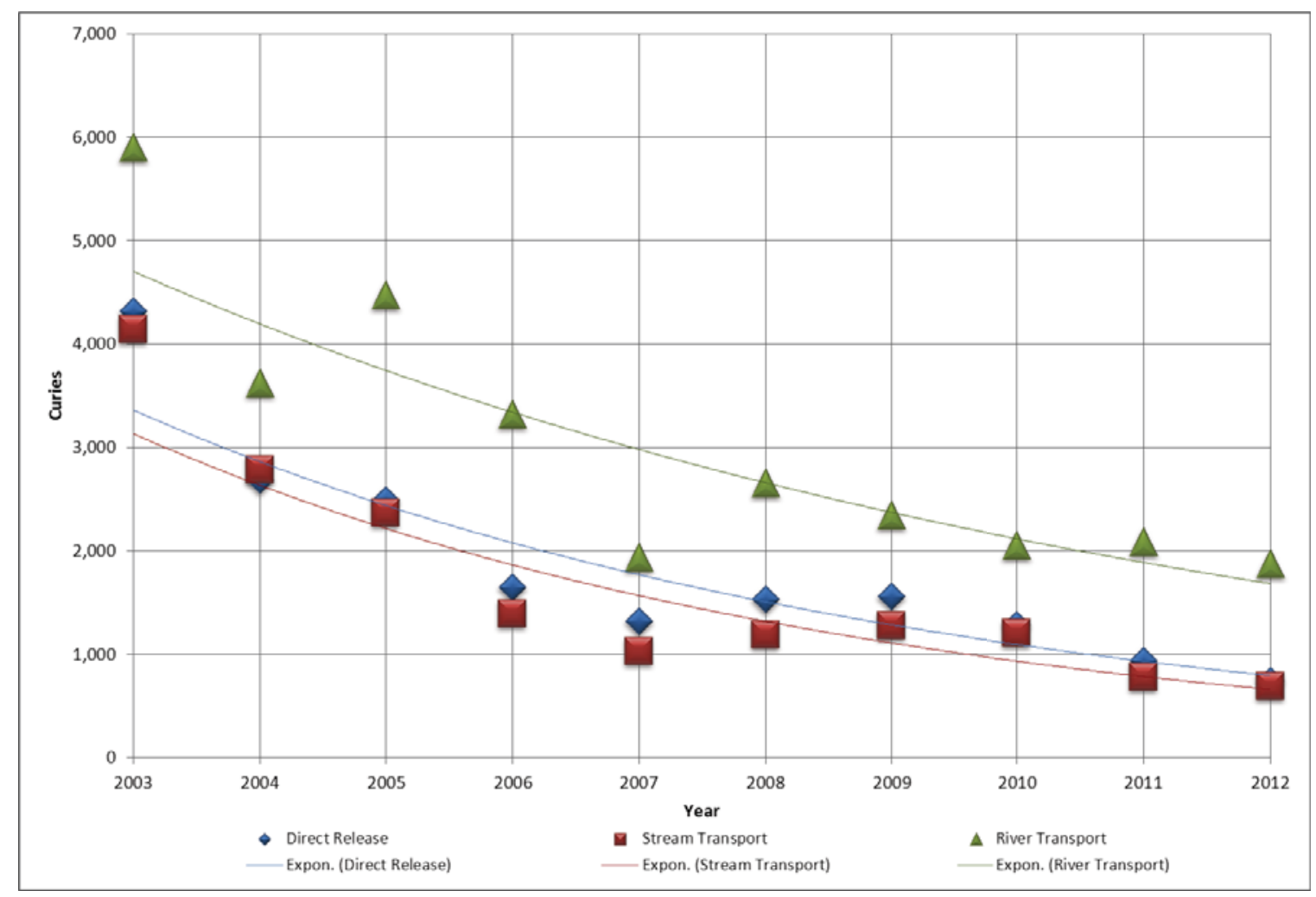

Figure 5-13 Ten-Year Trend of SRS Tritium Transport, 2003 - 2012

\section{Results Summary}

In 2012, tritium levels declined: Specifically:

- The direct releases of tritium in 2012 decreased by approximately $21 \%$ (from $942 \mathrm{Ci}$ in 2011 to $746 \mathrm{Ci}$ in 2012).

- The stream transport of tritium in 2012 decreased by approximately $11 \%$ (from $776 \mathrm{Ci}$ in 2011 to $690 \mathrm{Ci}$ in 2012).

- The river transport of tritium in 2012 decreased by approximately $10 \%$ (from 2,090 $\mathrm{Ci}$ in 2011 to 1,874 $\mathrm{Ci}$ in 2012). Both VEGP and SRS contributed to these values.

Stream transport plus the reported VEGP total of $1,181 \mathrm{Ci}$ equates to 1,871 $\mathrm{Ci}$ which is very close to the river transport estimate of 1,874 Ci. For the 2012 dose calculations, the highest value between the SRS direct releases and stream transport measurements (which was $746 \mathrm{Ci}$ ) is added to the VEGP reported tritium release total of 1,181 Ci to obtain an overall tritium total of 1,927 Ci (see Chapter 6, "Radiological Dose Assessments").

In the past few years, a small but measurable amount of tritium from a non-SRS source, a low-level radioactive waste disposal facility operated by Energy Solutions, LLC, continues to enter the SRS stream system. The facility is privately owned and adjacent to SRS. The tritium currently in groundwater will continue to decay and dilute as it moves from the source toward Lower Three Runs. SRS and SCDHEC maintain a monitoring program for Lower Three Runs to evaluate this tritium migration.

\section{Drinking Water Monitoring}

SRS collects drinking water samples from 13 locations at SRS and at four water treatment facilities that use Savannah River water. SRS monitors potable water at offsite treatment facilities to ensure that SRS operations do not adversely affect the water supply and to provide assurance that drinking water does not exceed EPA drinking water standards for radionuclides. 
Onsite drinking water sampling consisted of grab samples at large treatment plants in A Area and D Area and grab samples at wells and small systems. SRS collects composite samples offsite from the following locations:

- Beaufort-Jasper Water and Sewer Authority's Chelsea Water Treatment Plant,

- Beaufort-Jasper Water and Sewer Authority's Purrysburg Water Treatment Plant,

- City of Savannah Industrial and Drinking Water Supply Plant, and

- North Augusta (South Carolina) Water Treatment Plant.

\section{Results Summary}

In 2012, SRS performed gross alpha and gross beta screening on all onsite and offsite drinking water samples. No drinking water exceeded EPA's $15 \mathrm{pCi} / \mathrm{L}$ alpha activity limit or $50 \mathrm{pCi} / \mathrm{L}$ beta activity limit. In addition, no onsite or offsite drinking water samples exceeded the $20,000 \mathrm{pCi} / \mathrm{L}$ EPA tritium limit or the $8 \mathrm{pCi} / \mathrm{L}$ strontium- $89,90 \mathrm{MCL}$.

Cobalt-60, cesium-137, strontium-89, 90, uranium-235, plutonium-238, plutonium-239, americium-241, and curium-244 were not detectable in any drinking water samples. Sample results indicated detectable levels of uranium-234 in eight onsite samples and uranium-238 in seven onsite samples (Data Table 5-12). All analytical results are well below the EPA MCL for alpha emitting radionuclides.

\section{Food Product Monitoring}

\section{Terrestrial Food Products}

The terrestrial food products surveillance program consists of radiological analyses of food product samples typically found in the Central Savannah River Area (CSRA) to determine whether SRS operations are affecting the public through the food chain. Agricultural products, livestock, and game animals for human consumption may contain radionuclides. SRS samples foods including milk, meat, fruit, nuts, and green vegetables because of the potential to transport radionuclides to people via the food chain.

Samples of food, including meat, fruit, and a green vegetable, are collected from one location within each of four SRS quadrants and from a location within an extended (to $25 \mathrm{mi}$ beyond the perimeter) southeast quadrant (Figure 5-1). SRS personnel collect milk from six dairies within a 25-mile radius of the SRS. In general, as part of the food product surveillance, SRS conducts a three-year rotating schedule for sampling of meat, fruit, and green vegetables. Beef, collards, soybeans, corn, and watermelon were sampled in 2012 as part of this program. Laboratory analysis of the food samples includes gamma-emitting radionuclides, tritium, strontium-89, 90, uranium- 234, uranium-235, uranium-238, neptunium-237, plutonium-238, plutonium-239, americium-241, curium-244, technetium-99, gross alpha activity, and gross beta activity.

\section{Results Summary}

Results for terrestrial food products and dairy are included in Data Tables 5-13 and 5-14, respectively. Tritium releases from SRS and non-SRS sources are the primary contributors to tritium in food products. SRS did not perform tritium analysis on soybeans because of inadequate moisture content in the soybean samples. In 2012, tritium was detected in fruit, beef, collards, and corn as shown in Table 5-12 and in milk as shown in Table 5-13. The four South Carolina dairies and two Georgia dairies in the SRS monitoring program had tritium concentrations above the MDC.

In 2012, cesium-137 was the only gamma-emitting radionuclide detected in food products. Cesium-137 is present in collards and corn, as shown in Table 5-12. Analysis detected strontium-89, 90 in collards and strontium-90 (Sr-90) in milk samples, as shown in Table 5-12 and Table 5-13, respectively. Five of the eight milk samples for the Georgia dairies in the SRS monitoring program were above the MDC. Seven of the 16 milk samples for the South Carolina dairies in the SRS monitoring program were above the MDC. The strontium-90 result is within the five year trend for the location. Uranium-234, uranium-235, and uranium-238 were detected above the MDC as shown in Table 5-12. 
The radioisotopes of uranium are naturally occurring in local soils. Analysis detected technetium-99 in collards at all locations, in beef at the southeast (SE) and northeast (NE) quadrants zero to ten miles from the SRS, in corn at the SE quadrant zero to ten miles from the SRS and in soybeans at the northeast quadrant zero to ten miles from the SRS. In the presence of oxygen, plants readily take up technetium compounds from the soils and small amounts are part of the environment. Gross beta activity was detected in all food products, except for fruit. No detectable levels of gross alpha were observed in any of the food products. The 2012 results appeared randomly distributed among the monitoring locations with no underlying spatial distribution.

Of the 2012 food products sample results; there are five new maximum values when compared to the previous four years. They are tritium in fruit and beef, uranium-234 in greens and soybeans, and uranium-238 in soybeans. The uranium-234 and uranium-238 maximums are located in the southwest (SW) quadrant. The presence of uranium isotopes in food products may be due to the natural levels of uranium in soils and may not be due to SRS operations. The tritium maximums are located in the NE and northwest (NW) quadrants for fruit and beef, respectively. Review of the results of the sampling of SRS air sources indicates no abnormal trends. Thus, these new maximums cannot be directly attributable to SRS operations.

Table 5-12 Radionuclides Detected in Food Products in 2012

\begin{tabular}{|l|c|c|c|}
\hline \multicolumn{1}{|c|}{ Analyte } & Food Product & $\begin{array}{c}\text { Locations by Quadrant in } \\
\text { which Analyte was Detected }\end{array}$ & $\begin{array}{c}\text { Maximum } \\
\text { Concentration } \\
\text { (pCi/g) }\end{array}$ \\
\hline Tritium (H-3) & Collards & NW, SE & 0.059 \\
\hline Tritium (H-3) & Fruit (melons) & NE, NW & 0.114 \\
\hline Tritium (H-3) & Corn & SW & 0.097 \\
\hline Tritium (H-3) & Beef & NE, NW, SE, SW, SE-25 mile & 0.196 \\
\hline Cs-137 & Collards & NW, SE, SW & 0.064 \\
\hline Cs-137 & Corn & NW & 0.010 \\
\hline Sr-89/90 & Collards & NE, NW, SE & 0.179 \\
\hline U-234 & Collards & NE, NW, SE, SW & 0.005 \\
\hline U-234 & Fruit (melons) & NE, SW-25 mile & 0.0002 \\
\hline U-234 & Soybeans & NE, NW, SE, SW,SE-25 mile & 0.077 \\
\hline U-234 & Beef & SW & 0.0005 \\
\hline U-235 & Collards & SW & 0.0008 \\
\hline U-235 & Soybeans & NE, NW, SE & 0.004 \\
\hline U-238 & Collards & NE, SW & 0.005 \\
\hline U-238 & Soybeans & NE, NW, SE, SW & 0.058 \\
\hline U-238 & Beef & NE, SE & 0.0004 \\
\hline Tc-99 & Collards & NE, NW, SE, SW, SE-25 mile & 1.78 \\
\hline Tc-99 & Corn & SE & 0.191 \\
\hline Tc-99 & Soybeans & Beef & 0.019 \\
\hline Tc-99 & & 0.125 \\
\hline
\end{tabular}

All quadrants, except as noted, are within 10 miles of the SRS boundary. Locations annotated in bold are the quadrants in which the maximum concentration was detected.

Table 5-13 Radionuclides Detected in Milk Products in 2012

\begin{tabular}{|l|c|c|c|}
\hline \multicolumn{1}{|c|}{ Analyte } & $\begin{array}{c}\text { Number of } \\
\text { Samples }\end{array}$ & $\begin{array}{c}\text { Number of } \\
\text { Detects }\end{array}$ & $\begin{array}{c}\text { Maximum } \\
\text { Concentration (pCi/L) }\end{array}$ \\
\hline Sr-90 & 24 & 12 & 1.59 \\
\hline Tritium (H-3) & 24 & 11 & 489 \\
\hline
\end{tabular}




\section{Aquatic Food Products}

The aquatic food product surveillance program includes fish (freshwater and saltwater) and shellfish. SRS maintains an ongoing program for collecting and analyzing fish from the Savannah River and surrounding freshwater bodies. Various species of fish collected offsite from streams and tributaries are included in the determination of the potential dose and risk to the public from consumption. Nine surveillance points for the collection of freshwater fish are on the Savannah River from above SRS at Augusta, Georgia to the coast at Savannah, Georgia. One surveillance point for the collection of freshwater fish is on the Edisto River at West Bank Landing. One surveillance point for the collection of saltwater fish is at the mouth of the Savannah River, near Savannah, Georgia. Composite samples composed of three to five fish of a given species are prepared for each species from each location. SRS uses three categories of freshwater fish: bass, panfish (bream), or catfish. Saltwater fish include composites of sea trout, red drum (spottail bass), and mullet. Fish categories are based on the most common fish caught in the Savannah River. SRS analyzes two types of composites. They are edible (meat and skin only) and non-edible (bone) composites. Analyses conducted on edible composites include tritium, gross alpha, gross beta, gamma-emitting radionuclides, strontium-89, 90, technetium-99, iodine-129, and the actinide series. Strontium-89, 90 is the only analyses conducted on the non-edible composites. Prior to 2012, the non-edible analysis included the same analyses as the edible analysis. This change is the result of incorporating a recommendation from the updated Critical Radionuclide and Pathway Analysis for the Savannah River Site (Jannik et al., 2011).

\section{Results Summary}

Aquatic food product results for saltwater fish are provided in Data Table 5-15. For freshwater fish, Data Table 5-16 provides detailed results. The results for shellfish are reported in Data Table 5-17. Figure 5-14 depicts fish collection on the Savannah River. In 2012, SRS revised the method for computing the mean value. The mean is set to zero when the three composites for the species are below the MDC.

Gross alpha results were below the MDC for all edible fish composites of saltwater and freshwater fish. Gross beta activity was detectable in all freshwater fish composites and saltwater marine mullet at maximum concentrations of 3.92 $(+/-0.286) \mathrm{pCi} / \mathrm{g}$ and $2.76(+/-0.243) \mathrm{pCi} / \mathrm{g}$, respectively. This is most likely attributed to the naturally occurring radionuclide potassium- 40 . Iodine-129 was greater than the MDC in one freshwater fish composite from Augusta Lock and Dam at $0.052(+/-.016) \mathrm{pCi} / \mathrm{g}$ and not detected (or less than the MDC) in saltwater fish composites. Cesium-137 was detected above the MDC in $31 \%$ of the freshwater fish composites at a maximum of $0.422(+/-0.0373) \mathrm{pCi} / \mathrm{g}$. Cesium-137 average and maximum concentrations for bass at the mouth of Fourmile Branch

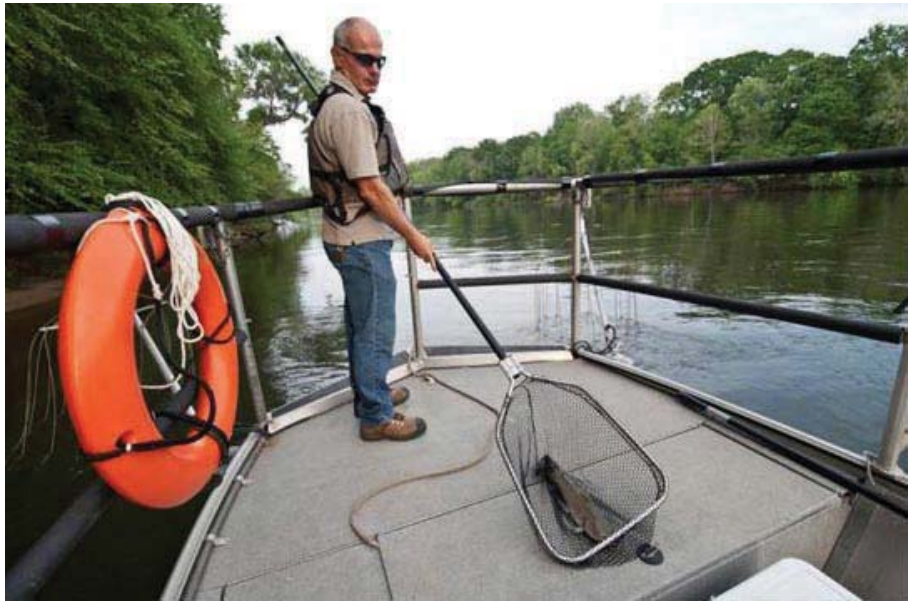

Figure 5-14 Fish Sample Collection on Savannah River are greater than results for the previous 4 years. Average and maximum concentrations of cesium- 137 for both panfish and catfish are within historical trends. As shown in Figure 5-15, sporadic maximums that are outside the general trend have occurred at individual locations along the SRS boundary. In 2012, shallow groundwater migration of cesium-137 into Fourmile Branch showed a slight increase (Table 5-10). This may have contributed to the increased level of cesium-137 in bass. Figure 5-16 depicts the natural log of cesium-137 levels from 1964-2012 in fish composites from River Mile 118.8 graphically with the radioactive decay of cesium-137. As shown in the graph, the cesium-137 levels in fish are much lower than what would be expected from the natural decay process. This is important because the dose impact has been reduced quicker than what one would expect based on natural decay alone. Analysis of saltwater fish found no man-made gamma-emitting radionuclides. 


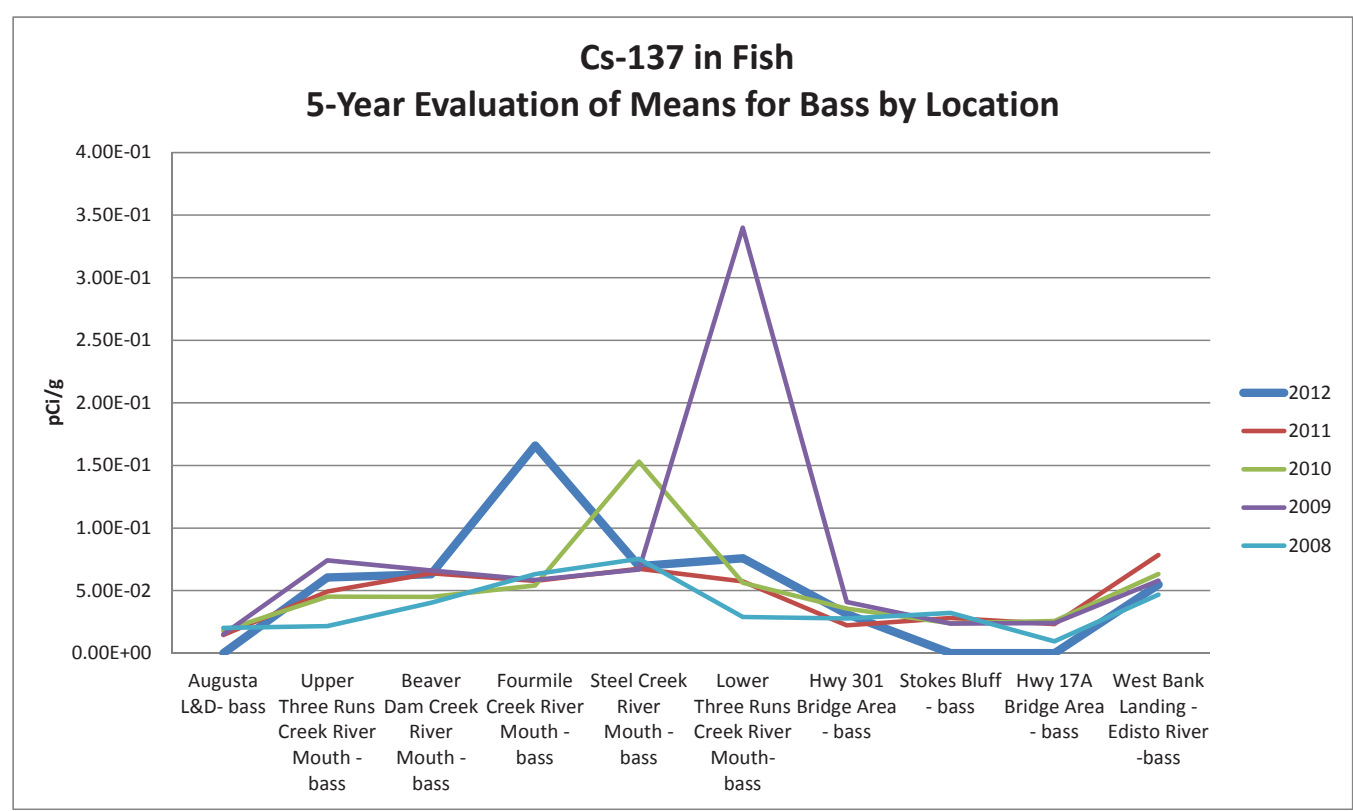

Figure 5-15. Evaluation of Cesium-137 Means (pCi/g) in Bass for the Period 2008 through 2012

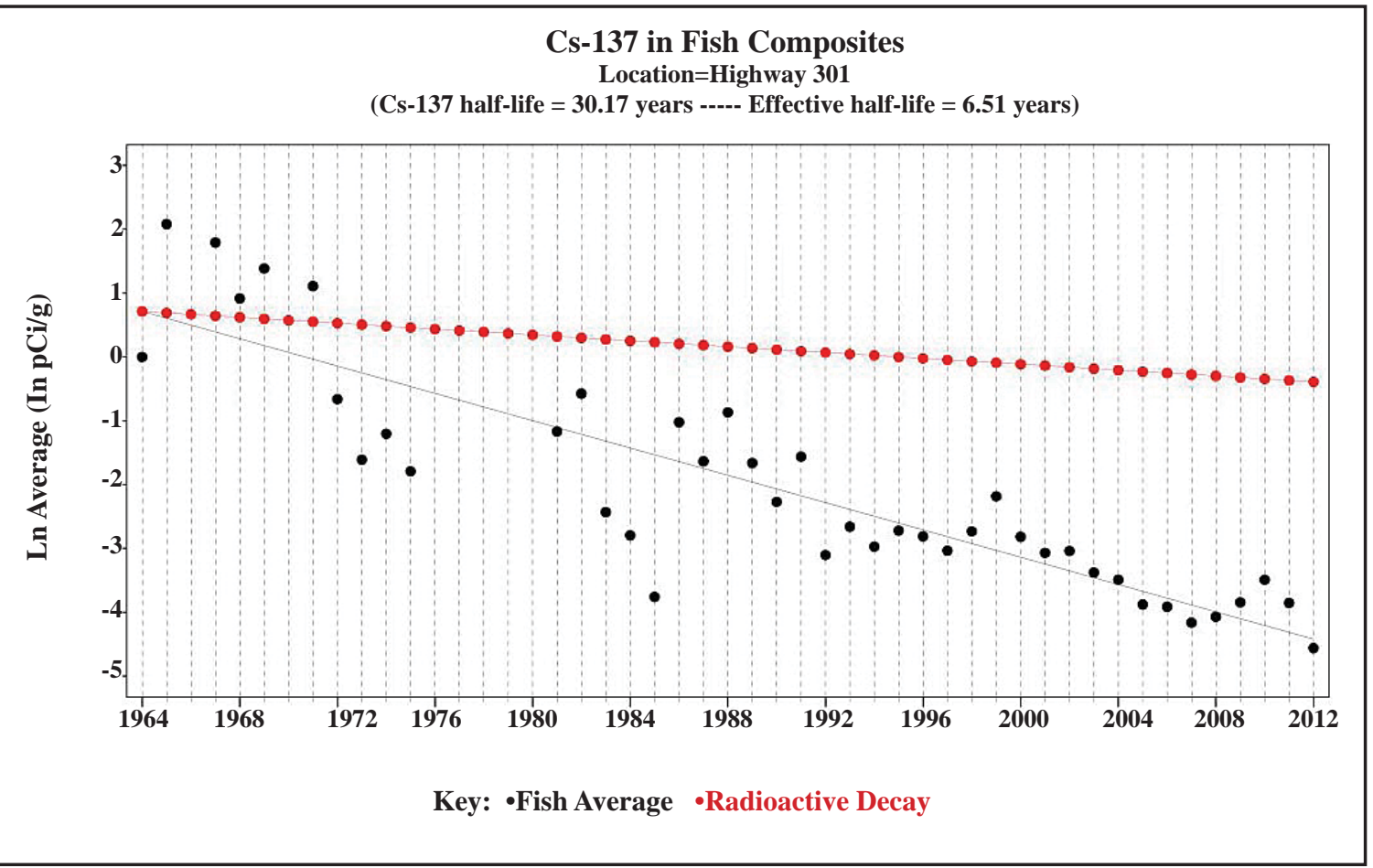

Figure 5-16 Fish Composite Concentrations (at RM-118.8) versus

Radioactive Decay for Cesium-137

Strontium-89, 90 was greater than the MDC in $99 \%$ of the nonedible freshwater fish composites at a maximum of $0.278(+/-0.02) \mathrm{pCi} / \mathrm{g}$ and in $25 \%$ of the nonedible saltwater fish composites at maximum of $0.0289(+/-0.007) \mathrm{pCi} / \mathrm{g}$. Concentrations of uranium-234, uranium-235, uranium-238, and tritium in freshwater and saltwater fish composites were similar to those of previous years. For the saltwater fish composites, technetium-99 was below the MDC. For the freshwater fish, $26 \%$ of the composites contained technetium-99 above the MDC, with a maximum value of 0.120 $(+/-0.03) \mathrm{pCi} / \mathrm{g}$. No plutonium-239 or plutonium-238 was detectable in any of the freshwater and saltwater fish composites. 
Gross beta were detected in shellfish at a concentration of $1.00(+/-0.244) \mathrm{pCi} / \mathrm{g}$. There were no detectable levels of gross alpha in shellfish. These levels were within the historical statistical trends. Concentrations of uranium-234, uranium-235, and uranium-238 in shellfish were at levels similar to those of previous years. No detectable levels of strontium-89, 90, iodine-129, plutonium-238, plutonium-239, americium-241, and curium-244 greater than the MDC were present in shellfish.

Calculations of risk from the consumption of fish from the Savannah River are included in Chapter 6 "Radiological Dose Assessments."

\section{Wildlife Monitoring}

\section{Deer, Hog, and Coyote}

Annual game animal hunts, open to members of the general public, are conducted to control SRS's deer and feral hog populations and to reduce animal-vehicle collisions. Prior to releasing any animal for consumption to a hunter, SRS uses portable sodium iodide detectors to perform field analyses for cesium-137. Figure 5-17 shows a deer carcass being screened. SRS collects samples for laboratory analysis of cesium-137 concentrations in deer (muscle and bone) samples based on (1) a set frequency, (2) the cesium-137 levels, or (3) exposure limit considerations.

Cesium-137 is chemically analogous to potassium in the environment and behaves similarly. It has a half-life of

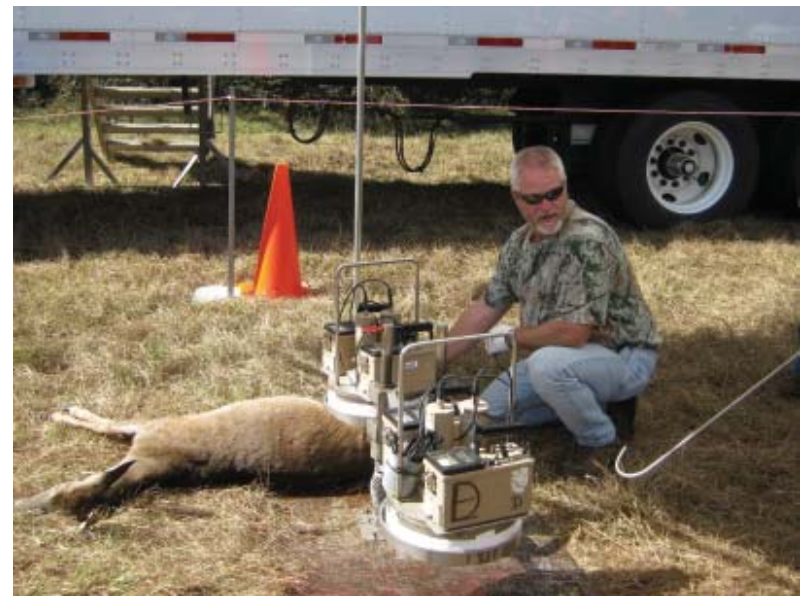

Figure 5-17 Field Monitoring During the Annual Deer Hunt about 30 years and tends to persist in soil. If it is in soluble form, it can readily enter the food chain through plants. It is widely distributed throughout the world from historic nuclear weapons detonations from 1945 to 1980 and is present at low levels in all environmental media.

In 2012, SRS reduced its game animal administrative dose limit to $22 \mathrm{mrem} / \mathrm{yr}$ for the release of animals from the Site. The revised limit ensures the game animal pathway contributes no more than $25 \%$ to the all-pathway dose limit of 100 $\mathrm{mrem} / \mathrm{yr}$. The previous game animal limit was $30 \mathrm{mrem}$. The doses from deer and hog consumption are quantified and reported in Chapter 6, "Radiological Dose Assessments."

\section{Results Summary}

A total of 543 deer, 100 feral hogs, and 38 coyote were harvested and released for consumption during the 2012 SRS hunts. As observed during previous hunts, cesium-137 was the only man-made gamma-emitting radionuclide detected in muscle tissue during laboratory analysis. Strontium-89, 90, a beta-emitting radionuclide was detected in both bone and muscle tissue.

Table 5-14 2012 Cesium-137 Results for Laboratory and Field Measurements

\begin{tabular}{|c|c|c|c|c|c|}
\hline 2012 & Number of Animals & $\begin{array}{c}\text { Field Gross Average } \\
\text { Cs-137 (pCi/g) }\end{array}$ & $\begin{array}{c}\text { Field Maximum } \\
\text { Cs-137 (pCi/g) }\end{array}$ & $\begin{array}{c}\text { Lab Average } \\
\text { Cs-137 (pCi/G) }\end{array}$ & $\begin{array}{c}\text { Lab Maximum } \\
\text { Cs-137 (pCi/g) }\end{array}$ \\
\hline Deer & 543 & 0.88 & 12.6 & 1.61 & 13.1 \\
\hline Hog & 100 & 0.71 & 4.81 & 0.94 & 2.14 \\
\hline Coyote & 38 & 1.09 & 2.49 & ----- & ---- \\
\hline
\end{tabular}

Generally, cesium-137 concentrations measured by field detectors and laboratory methods were comparable. Field measurements for cesium-137 from all released animals ranged from the lowest default value of $1.00 \mathrm{pCi} / \mathrm{g}$ to 12.62 $\mathrm{pCi} / \mathrm{g}$ while laboratory measurements ranged from $0.21 \mathrm{pCi} / \mathrm{g}$ to $13.1(+/-0.863) \mathrm{pCi} / \mathrm{g}$. Laboratory measurement results are included in Data Tables 5-18 and 5-19 for deer tissue and bone, and in Data Tables 5-20 and 5-21 for hog tissue and bone. Results of field and laboratory measurements are summarized in Table 5-14. The muscle and bone samples from a subset of the animals returned to the laboratory for cesium-137 analysis are analyzed for strontium-89, 90. Because of its chemistry, strontium exists at higher concentration in bone than in muscle tissue. 
Average cesium- 137 concentrations in deer have indicated an overall decreasing trend for the past ten years. The historical trend analysis is in Figure 5-18.

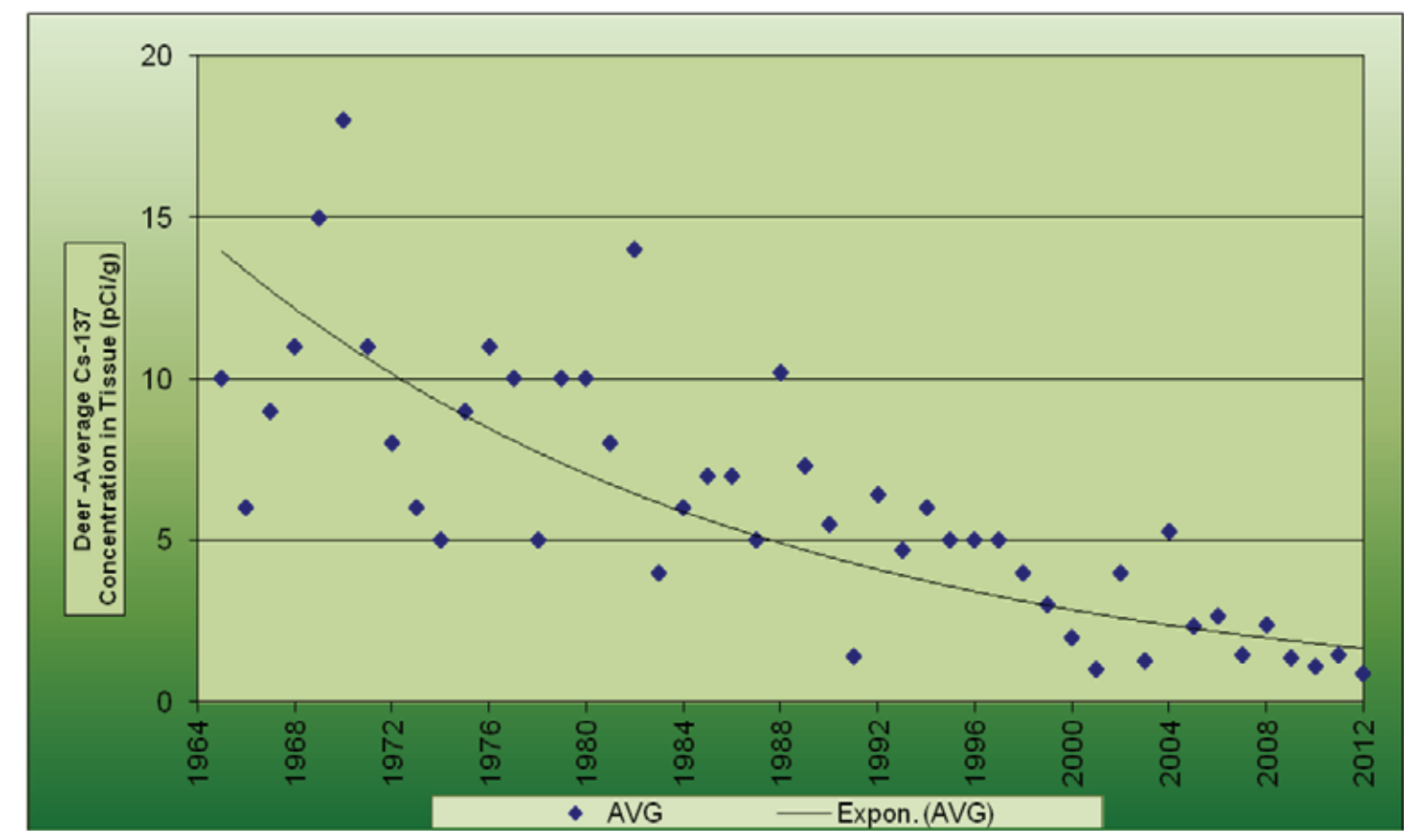

Figure 5-18 Historical Trend of Cesium-137 Concentration in Deer (pCi/g), 1965 - 2012

In 2012, all 84 deer bone samples had detectable levels of strontium-89, 90 greater than the MDC with an average of $3.59(+/-0.272) \mathrm{pCi} / \mathrm{g}$ and a maximum of $6.76(+/-0.431) \mathrm{pCi} / \mathrm{g}$. For the deer muscle tissue samples, 12 out of the 84 muscle tissue samples had detectable levels greater than the MDC for strontium-89,90 with a maximum of $0.046(+/-$ 0.004). Strontium- 89,90 was also greater than the MDC in the six hog bone samples at a maximum of $3.04(+/-0.252)$ $\mathrm{pCi} / \mathrm{g}$ and below the MDC for the hog muscle tissue samples. These results are similar to those of previous years.

\section{Turkey}

SRS hosted a special turkey hunt during April 2012 for hunters with mobility impairments. Twenty-eight turkeys were harvested and released to hunters for consumption.

\section{Results Summary}

All field measurement results for the 28 turkeys harvested had cesium-137 levels at or below the lowest default value of $1.00 \mathrm{pCi} / \mathrm{g}$, which is comparable with the results from previous special hunts. 


\section{Soil Monitoring}

SRS conducts soil monitoring to provide:

- Data for long-term trending of radioactivity deposited from the atmosphere (both wet and dry deposition), and

- Information on the concentrations of radioactive materials in the environment.

Concentrations of radionuclides in soil vary greatly among locations because of differences in rainfall patterns and retention and transport in different types of soils. Therefore, a direct comparison of data from year-to-year is not appropriate. However, the data is evaluated for long-term trend analyses. Soil sampling involves the use of hand augers, shovels, or other similar devices for collection to a depth of 3 inches (Figure 5-19). The samples are

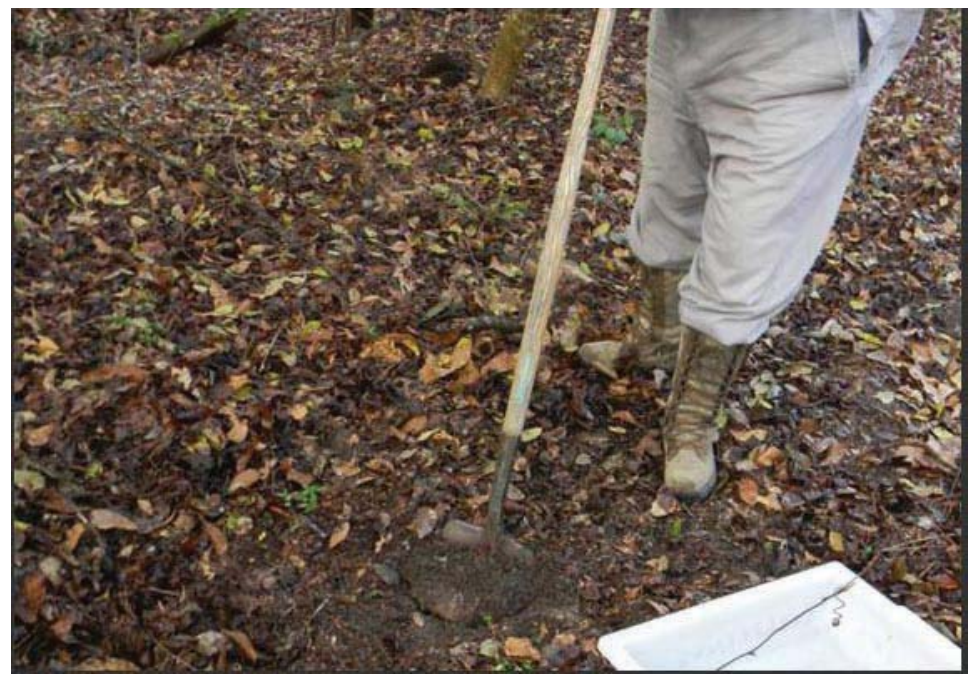

Figure 5-19 Soil Sampling Collection analyzed for gamma-emitting radionuclides, strontium-89, 90, and the actinides.

\section{Results Summary}

In 2012, radionuclides were detected in soil samples from all 21 sampling locations (five onsite, 12 at the perimeter, and four offsite), as follows:

- Cesium-137 at all locations with the exception of one of the onsite locations near the burial ground,

- Uranium-234 at all 21 locations,

- Uranium-235 at all 21 locations,

- Uranium-238 at all 21 locations,

- Plutonium-238 at four locations (two onsite, one at the SRS perimeter, one offsite at Augusta Lock and Dam 25 miles from the SRS),

- Plutonium-239 at 19 locations (four onsite, 11 at the SRS perimeter, four (all) offsite),

- Strontium-89, 90 at four locations (two onsite, two offsite at locations Highway 301 and Augusta Lock and Dam 25 miles from the SRS),

- Americium-241 at eight locations (one onsite, five at the SRS perimeter, two offsite at locations Aiken Airport and Augusta Lock and Dam 25 miles from the SRS), and

- Curium-244 at four locations (one onsite, one at the SRS perimeter, two offsite at locations Aiken Airport and Augusta Lock and Dam 25 miles from the SRS).

The concentrations at these locations are consistent with historical results (Data Table 5-22). No soil concentrations at the SRS perimeter or offsite exceeded the limit for SRS Soil Contamination Areas of $150 \mathrm{pCi} / \mathrm{g}$. The SRS Radiological Control Organization controls the locations onsite that do exceed the limit. Uranium is naturally occurring in soil and therefore expected to be present in soil samples.

\section{Sediment Monitoring}

Sediment sample analysis measures the movement, deposition, and accumulation of long-lived radionuclides in streambeds and in the Savannah River bed. Significant year-to-year differences may be evident because of the continuous deposition and remobilization occurring in the stream and river beds (or because of slight variations in sampling locations), but the data obtained can be used to observe long-term environmental trends. Sediment samples were collected at eight Savannah River locations and 21 onsite stream, basins, ponds, or swamp discharge locations during 2012. 


\section{Results Summary}

Cesium-137 was the only man-made gamma-emitting radionuclide observed in river and stream sediments during 2012. The highest cesium-137 concentration in streams, $154(+/-9.89) \mathrm{pCi} / \mathrm{g}$, was detected in sediment from R-Canal (100-R Location); the lowest levels were below the MDC level at eight locations. The highest level from the river, $(0.605+/-0.054) \mathrm{pCi} / \mathrm{g}$, was at RM 150.2; the lowest levels were below detection at three locations. Generally, cesium-137 concentrations were higher in stream sediments than in river sediments, reflecting the Site operations since SRS streams receive radionuclide containing liquid effluents from SRS. Most radionuclides settle out and deposit on the stream beds or at stream entrances to swamp areas along the river. Strontium-89, 90 was above the MDC in sediment at eight stream locations in 2012. The maximum detected value was $0.256(+/-0.043) \mathrm{pCi} / \mathrm{g}$ in the Fourmile Branch (Beaver Pond) location.

Plutonium-238 was detected in sediment during 2012 at 11 locations onsite and no offsite river locations. The results ranged from below the MDC to a maximum of $2.36(+/-0.227) \mathrm{pCi} / \mathrm{g}$ in Fourmile Branch (onsite at Road 4). Plutonium-239 was detected in sediment at 13 onsite locations and no offsite river locations. The maximum value was 0.210 (+/-0.021) pCi/g at Pond 400. Uranium-234, uranium-235, and uranium-238 were detected at all locations at levels similar to previous years. The distribution and concentration of radionuclides in river sediment during 2012 were similar to those of previous years (Data Table 5-23). Concentrations of all isotopes generally were higher in streams than in the river. As indicated in the earlier discussion of cesium-137, this is to be expected.

Differences observed when these data are compared to those of previous years are most likely attributable to the effects of re-suspension and deposition, which occur constantly in sediment media.

\section{Settleable Solids Monitoring}

Settleable solids monitoring in effluent water is required to determine, in conjunction with routine sediment monitoring, whether a long-term buildup of radioactive materials occurs in stream systems. DOE limits the radioactivity levels in settleable solids to $5 \mathrm{pCi} / \mathrm{g}$ above background for alpha-emitting radionuclides and $50 \mathrm{pCi} / \mathrm{g}$ above background for beta/gamma-emitting radionuclides.

Accurate measurement of radioactivity levels in settleable solids is impractical in small amounts of settleable solids with low Total Suspended Solids (TSS). TSS levels below 40 parts per million (ppm) comply with DOE limits. To determine compliance with these limits, SRS uses TSS results gathered as part of the routine National Pollutant Discharge Elimination System (NPDES) monitoring program from outfalls co-located at or near radiological effluent points.

\section{Results Summary}

In 2012, all NPDES TSS sample results were below $40 \mathrm{ppm}$. The 2012 NPDES TSS results indicate that SRS remains in compliance with DOE's requirement related to radioactivity levels in settleable solids.

\section{Vegetation Monitoring}

SRS conducts the radiological program for grassy vegetation from onsite and offsite locations to complement soil and sediment samples for evaluation of the environmental accumulation of radionuclides and to help validate SRS dose models. Vegetation can be contaminated externally by the deposition of airborne radioactive contaminants and internally by uptake from soil or water by the roots. Bermuda grass is preferred for monitoring because of its importance as a pasture grass for dairy herds. Figure

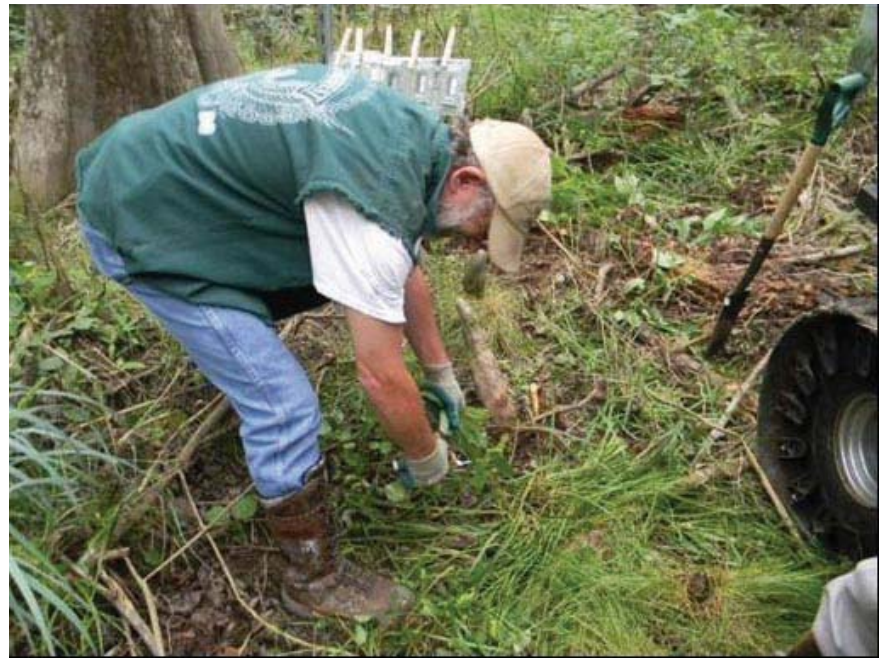

Figure 5-20 Environmental Monitoring Field Technician Collects Grassy Vegetation 5-20 shows collection of vegetation for monitoring. 
Vegetation samples include:

- Locations containing soil radionuclide concentrations expected to be higher than normal background levels,

- Locations receiving water that has the potential to be contaminated, and

- All air sampling locations.

Vegetation samples are analyzed for tritium, gross alpha, gross beta, gamma-emitting radionuclides, strontium-89, 90 , and the actinides.

\section{Results Summary}

SRS detected radionuclides in the grassy vegetation samples collected during 2012 in all 17 locations (one onsite, 12 at the perimeter, and four offsite). The detected radionuclides are as follows:

- Tritium at all 17 locations,

- Cesium-137 at eight locations (six at the perimeter, one offsite at Aiken Airport 25 miles from SRS, one offsite at Savannah 100 miles from SRS,

- Strontium-89, 90 at 14 locations (one onsite, nine at the perimeter, four (all) offsite),

- Uranium-234 at 10 locations (eight at the perimeter, one offsite at Augusta Lock and Dam 25 miles from SRS, one offsite at Savannah 100 miles from SRS),

- Uranium-238 at 11 locations (nine at the perimeter, one offsite at August Lock and Dam 25 miles from SRS, one offsite at Savannah 100 miles from SRS),

- Technium-99 at all locations with the exception of one of the onsite location near D Area,

- Gross beta at all 17 locations, and

- Gross alpha at one SRS perimeter location.

No levels were above the MDC for neptunium-237, plutonium-238, plutonium-239, americium-241, curium-244, or uranium-235. Average tritium results show a slight increase from 2011 to 2012 with levels ranging from below the MDC to $2.12(+/-0.03) \mathrm{pCi} / \mathrm{g}$ at the BGN location. Results for the other radionuclides are within the statistical trends of the previous five years. (Data Table 5-24).

\section{Nonradiological Monitoring}

SRS conducts nonradioactive surveillance sampling and analysis of surface water, drinking water, rainwater/wet disposition (Chapter 9, "Special Studies"), air, sediment, groundwater (Chapter 7, "Groundwater"), and fish, according to water and air quality standards and/or potential contaminants pathways into the environment. Table 5-15 summarizes the nonradiological sampling media frequencies.

Table 5-15 Nonradiological Sampling Frequencies

\begin{tabular}{|c|c|c|c|c|c|c|}
\hline \multirow{2}{*}{\multicolumn{2}{|c|}{ Media }} & \multicolumn{5}{|c|}{ Sampling Frequency } \\
\hline & & \multirow[t]{2}{*}{ Weekly } & \multirow[t]{2}{*}{ Bi-Weekly } & \multirow{2}{*}{$\begin{array}{c}\text { Monthly } \\
\checkmark\end{array}$} & \multirow[t]{2}{*}{ Quarterly } & \multirow[t]{2}{*}{ Annual } \\
\hline $\begin{array}{l}\text { Surface } \\
\text { Water }\end{array}$ & $\begin{array}{l}\text { Water quality down- } \\
\text { stream of NPDES outfalls } \\
\text { (stream and river) }\end{array}$ & & & & & \\
\hline Sediment & $\begin{array}{l}\text { Surveillance for existence } \\
\text { and possible buildup of } \\
\text { the inorganic } \\
\text { contaminants }\end{array}$ & & & & & $\sqrt{ }$ \\
\hline Fish & $\begin{array}{l}\text { Bioaccumulation of non- } \\
\text { radiological contaminants } \\
\text { in fish }\end{array}$ & & & & & $\checkmark$ \\
\hline $\begin{array}{l}\text { Drinking } \\
\text { Water }\end{array}$ & $\begin{array}{l}\text { Safe Drinking Water Act } \\
\text { compliance }\end{array}$ & & & $\checkmark$ & $\checkmark$ & $\sqrt{ }$ \\
\hline
\end{tabular}




\section{Surface Water Monitoring}

SRS streams and the Savannah River are classified as "Freshwaters" by South Carolina Regulation 61-69, "Classified Waters." Freshwaters are defined in Regulation 61-68, "Water Classifications and Standards" as:

- Primary and secondary contact recreation and as a drinking water source after conventional treatment in accordance with SCDHEC requirements,

- Fishing and the survival and propagation of a balanced indigenous aquatic community of fauna and flora, and

- Industrial and agricultural uses.

Table 5-16 provides some of the specific South Carolina freshwater standards used in water quality surveillance, but because some of these standards are not quantifiable, they are not tracked in response form (e.g., amount of garbage found).

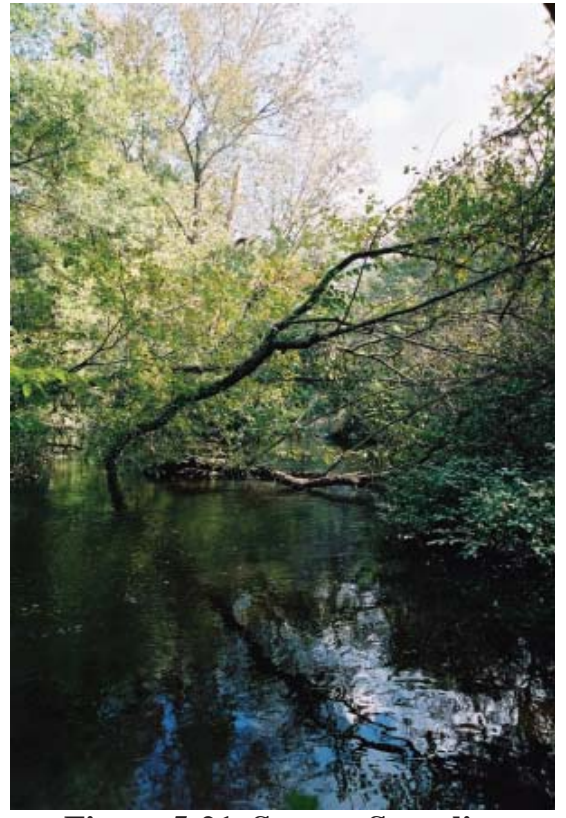

Figure 5-21 Stream Sampling Location

Table 5-16 South Carolina Water Quality Standards for Freshwaters

\begin{tabular}{|c|c|}
\hline Parameters & Standards \\
\hline E.coli & $\begin{array}{l}\text { Not to exceed a geometric mean of } 126 / 100 \mathrm{~mL} \text {, based on } \\
\text { at least four samples collected from a given sampling site } \\
\text { over a } 30 \text {-day period; nor shall a single sample maximum } \\
\text { exceed } 349 / 100 \mathrm{~mL} \text {. }\end{array}$ \\
\hline $\mathrm{pH}$ & Between 6.0 and 8.5 \\
\hline Temperature & $\begin{array}{l}\text { Generally, shall not be increased more than } 5^{\circ} \mathrm{F}\left(2.8^{\circ} \mathrm{C}\right) \\
\text { above natural temperature conditions or be permitted to } \\
\text { exceed a maximum of } 90^{\circ} \mathrm{F}\left(32.2^{\circ} \mathrm{C}\right) \text { as a result of the dis- } \\
\text { charge of heated liquids; for more details see E. } 12 \text {, Regula- } \\
\text { tion } 61-68 \text {, "Water Classifications" }\end{array}$ \\
\hline Dissolved oxygen & Daily average no less than $5.0 \mathrm{mg} / \mathrm{L}$, with a low of $4.0 \mathrm{mg} / \mathrm{L}$ \\
\hline Garbage, cinders, ashes, oils, sludge, or other refuse & None allowed \\
\hline $\begin{array}{l}\text { Treated wastes, toxic wastes, deleterious substances, } \\
\text { colored or other wastes, except in the parameter im- } \\
\text { mediately above }\end{array}$ & $\begin{array}{l}\text { None alone or in combination with other substances, or } \\
\text { wastes, in sufficient amounts to make the waters unsafe } \\
\text { or unsuitable for primary-contact recreation or to impair } \\
\text { the waters for any other best usage as determined for the } \\
\text { specific waters assigned to this class }\end{array}$ \\
\hline $\begin{array}{l}\text { Toxic pollutants listed in South Carolina Regulation } \\
\text { See Appendix: Water Quality Numeric Criteria for } \\
61-68 \text {, "Water Classifications and Standards" }\end{array}$ & $\begin{array}{l}\text { See Appendix: Water Quality Numeric Criteria for } \\
\text { 61-68, "Water Classifications and Standards" the Protec- } \\
\text { tion of Aquatic Life and Human Health, Regulation 61- } \\
\text { 68, "Water Classifications and Standards" (June 22, 2012) } \\
\text { http://www.scdhec.gov/environment/water/regs/r61-68.pdf }\end{array}$ \\
\hline
\end{tabular}




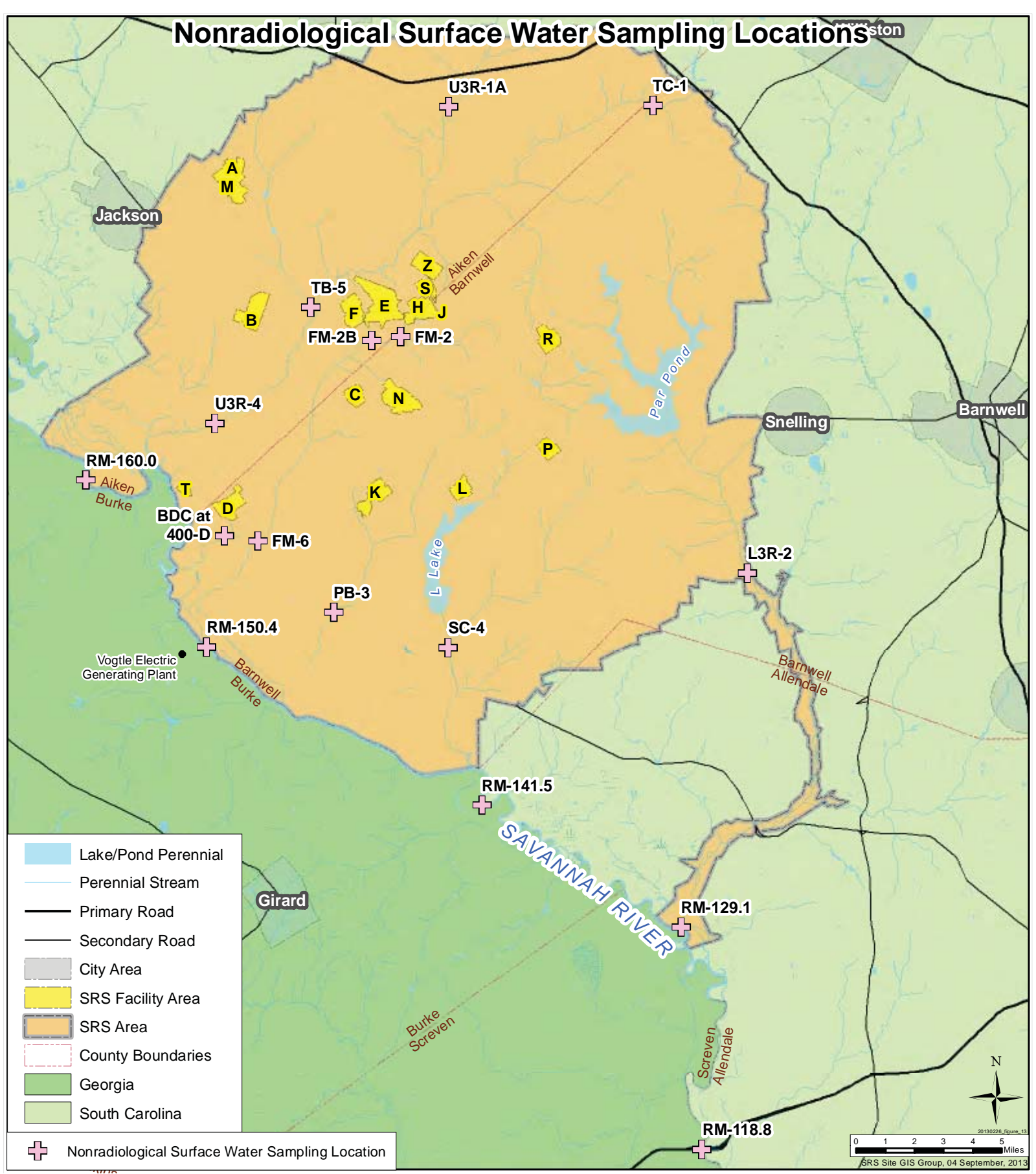

Figure 5-22 Nonradiological Surface Water Sampling Locations

Surface water samples are collected from five Savannah River and 11 SRS stream locations and are analyzed for various chemical and physical properties (Figure 5-22).

\section{Results Summary}

Water quality parameters were measured at all 16 sampling locations (Figure 5-22) in SRS streams and along the Savannah River during 2012 and metals were detected in at least one sample at each location. With the exception of off-patent pesticide, Endosulfan II, detected in July 2012 at Steel Creek, no other sample results showed detectable levels of pesticides or herbicides. These results continue to indicate that SRS discharges are not significantly affecting the water quality of onsite streams or the river (Data Table 5-25). 


\section{Drinking Water Monitoring}

Treatment plants in A Area and D Area supply most of the drinking water at SRS. The SRS also has 14 small drinking water facilities, each of which serves populations of fewer than 25 people.

\section{Results Summary}

All samples collected from SRS drinking water systems during 2012 were in compliance with SCDHEC and EPA water quality standards. The Safe Drinking Water Act section of Chapter 3, "Compliance Summary" provides additional information.

\section{Sediment Monitoring}

SRS's nonradiological sediment surveillance program provides a method to determine the deposition and accumulation of nonradiological contaminants in stream systems.

The nonradiological sediment program consists of the collection of sediment samples at eight onsite stream locations and three Savannah River locations. Collection is made by either a Ponar sediment sampler or an Emery pipe dredge sampler. The samples are analyzed for various inorganic contaminants (metals) and pesticides/herbicides by the Toxicity Characteristic Leaching Procedure (TCLP). This method analyzes for the soluble constituents in sediment. The program is designed to check for the existence and possible buildup of the inorganic contaminants as well as for pesticides/herbicides. SCDHEC performs duplicate sampling at various locations onsite as a quality control check of the SRS program. Those results are included with the routine SRS sediment sampling results in Data Table 5-26.

\section{Results Summary}

In 2012, as in the previous five years, no pesticides or herbicides were above the quantitation limits in sediment samples. No mercury was detected at any of the locations during 2012, as in previous years. Metals analysis showed some metals with levels greater than the practical quantitation limit for 2012 but were consistent with those seen in soil samples and comparable to those of the previous five years (Data Table 5-26).

\section{Fish Monitoring}

SRS collects and analyzes flesh of fish caught from the Savannah and Edisto Rivers to determine concentrations of mercury, arsenic, cadmium, manganese, and antimony in the fish.

\section{Results Summary}

In 2012, SRS analyzed 476 fish at 11 locations including Site streams, the Savannah River and the Edisto River at West Bank Landing for mercury, cadmium, arsenic, antimony, and manganese. Results for mercury and metals in fish are included in Data Tables 5-27 and 5-28, respectively. Review of mercury data for the period 2008 through 2012 (Figure 5-23) shows a consistent trend by location with concentrations decreasing at most locations beginning in 2009. SRS compared the data to the trigger levels used by SCDHEC and the Department of Natural Resources to issue fish advisories (SCDHEC, 2010). The mercury results for fish are within or below the levels for the SCDHEC-issued fish species advisories for the Savannah River and Edisto River (SCDHEC, 2012). The SRS mercury method detection limit for the fish analyses was $0.02 \mu \mathrm{g} / \mathrm{g}$. The highest concentrations were found in the Savannah River in the following species and locations: bass at Stokes Bluff Landing $(1.08 \mu \mathrm{g} / \mathrm{g})$, catfish at Stokes Bluff Landing $(0.497 \mu \mathrm{g} / \mathrm{g})$, and panfish at the Lower Three Runs Creek Mouth $(0.664 \mu \mathrm{g} / \mathrm{g})$. 




Figure 5-23 Average Mercury Concentrations in Fish by Location and Species for the Period 2008 through 2012

The highest concentrations of mercury in saltwater fish, collected only at River Miles 0-8 near Savannah, Georgia, are $0.041 \mu \mathrm{g} / \mathrm{g}$ in red drum, $0.024 \mu \mathrm{g} / \mathrm{g}$ in mullet, and $0.172 \mu \mathrm{g} / \mathrm{g}$ in sea trout. Review of the surveillance results for the remaining metals detected the following:

- Cadmium in 11 of the 476 fish samples collected in 2012. The highest concentration is in catfish $(0.126 \mu \mathrm{g} / \mathrm{g})$ from the mouth of Fourmile Branch,

- Arsenic in 22 fish samples with the highest concentration in catfish $(1.006 \mu \mathrm{g} / \mathrm{g})$ from the Highway 301 Bridge sampling location,

- Antimony in 25 fish samples, with the highest concentration in panfish $(0.959 \mu \mathrm{g} / \mathrm{g})$ at the mouth of Steel Creek, and

- Manganese at all 11 fish sampling locations, with the highest concentration in panfish $(12.336 \mu \mathrm{g} / \mathrm{g})$ at the mouth of Beaver Dam Creek.

\section{River Water Quality Monitoring}

Biological and water quality surveys are conducted to assess the potential effects of SRS contaminants and warmwater discharges on the general health of the river and its tributaries. SRS designed the surveys to assess the potential effects of SRS contaminants and discharges on the general health of the river and its tributaries by looking for:

- $\quad$ Patterns of biological disturbance geographically associated with the SRS, and

- Patterns of change over seasons or years that indicate improving or deteriorating conditions.

Streams, rivers, wetlands, and lakes are home for many small animals called macroinvertebrates. These animals generally include insects, crustaceans, mollusks, arachnids, and annelids. The term macroinvertebrate describes those animals that have no backbone and can be seen with the naked eye. These animals live in the water for all or part of their lives, so their survival is related to the water quality. They are significant within the food chain as larger animals such as fish and birds rely on them as a food source. Macroinvertebrates are sensitive to different chemical and physical conditions. If there is a change in the water quality, because of a pollutant entering the water, or a change in the flow downstream of a dam, then the macroinvertebrate community may also change. 
Diatoms are single-cell algae which can be identified from the shape of their skeleton. Diatoms provide information on both the biological integrity of the ecosystem and those factors likely to be causing any observed changes.

\section{Results Summary}

In 2012, SRS conducted macroinvertebrate sampling during the spring and fall and diatom sampling monthly. The diatom slides were sent to the Academy for Natural Sciences (ANS) for archiving. Macroinvertebrates collected from river traps during 2012 were similar in species diversity to those documented in surveys during the 1990s. An overall decrease in total populations is likely associated with low flow in the river and incipient drought conditions. 
This page intentionally left blank. 


\section{RADIOLOGICAL \\ DOSE ASSESSMENTS}

Timothy Jannik

Eduardo B. Farfan

Kenneth L. Dixon

Savannah River National Laboratory

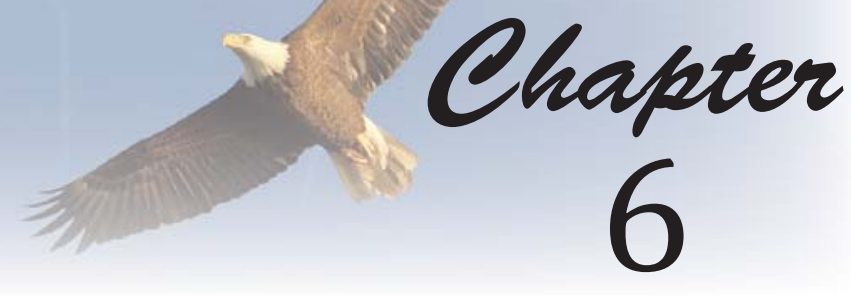

$T$ o ensure protection of the public and environment from radiation from U.S. Department of Energy's (DOE) facili1 ties, DOE Order 458.1, "Radiation Protection of the Public and the Environment", established an annual public dose limit and biota dose limits. The Savannah River Site (SRS) calculates the potential doses to members of the public from atmospheric and liquid radioactive releases and from special-case exposure scenarios such as the consumption of onsite wildlife to verify that these releases and exposures do not exceed the DOE public dose limits.

Routine SRS operations result in releases of radioactive materials to the environment by atmospheric and liquid pathways. These releases potentially result in a radiation exposure to people offsite. To confirm that this exposure is below public and biota dose limits, SRS calculates annual dose estimates using effluent release data, environmental monitoring, and surveillance data combined with relevant site specific data (such as meteorological conditions, population characteristics, and river flow).

All dose calculation results are presented in data tables on the CD inside the back cover of this report and are referred to in this chapter as "Data Table 6-X." Tables provided in this chapter are simply referred to as "Table 6-X."

Chapter 4, "Effluent Monitoring," and Chapter 5, "Environmental Surveillance" provide descriptions of the SRS effluent monitoring and environmental surveillance programs and are referenced throughout this chapter. For a complete description of how SRS calculates potential doses, see the SRS Environmental Dose Assessment Manual (SRS EDAM, 2010).

\section{What is a Dose?}

Dose is the amount of energy absorbed by the human body as a result of a radioactive source; it is measured in rem (which equals 0.01 sievert (Sv)) or in millirem (mrem), which is one-thousandth of a rem, and is the unit typically used in this report. Unless otherwise noted, the generic term "dose" used in this report is the total effective dose to a person, which includes both the committed effective dose (50-year committed dose) from internal deposition of radionuclides and the effective dose attributable to sources external to the body. Use of the total effective dose allows doses from different types of radiation and to different parts of the body to be expressed on the same basis.

Humans, plants, and animals potentially receive radiation doses from natural and man-made occurrences. The average annual "background" dose for Americans is $625 \mathrm{mrem}$; this includes an average background dose of $311 \mathrm{mrem}$ from naturally occurring radionuclides found in our bodies and in the earth, and from cosmic radiation. It also includes 300 mrem from medical procedures, 13 mrem from consumer products, and less than $1 \mathrm{mrem}$ from industrial and occupational exposures.

DOE has established dose limits to the public so that DOE operations will not contribute significantly to this average annual exposure. DOE Order 458.1 (DOE, 2011) establishes $100 \mathrm{mrem} / \mathrm{yr}(1 \mathrm{mSv} / \mathrm{yr}$ ) as the annual dose limit to a member of the public. 
Exposure to radiation primarily occurs through the following pathways:

- Inhalation,

- Ingestion,

- Skin absorption, and

- Direct (external) exposure to radionuclides in soil, air and water.

Figure 6-1 is a simplified representation of the principal exposure pathways.

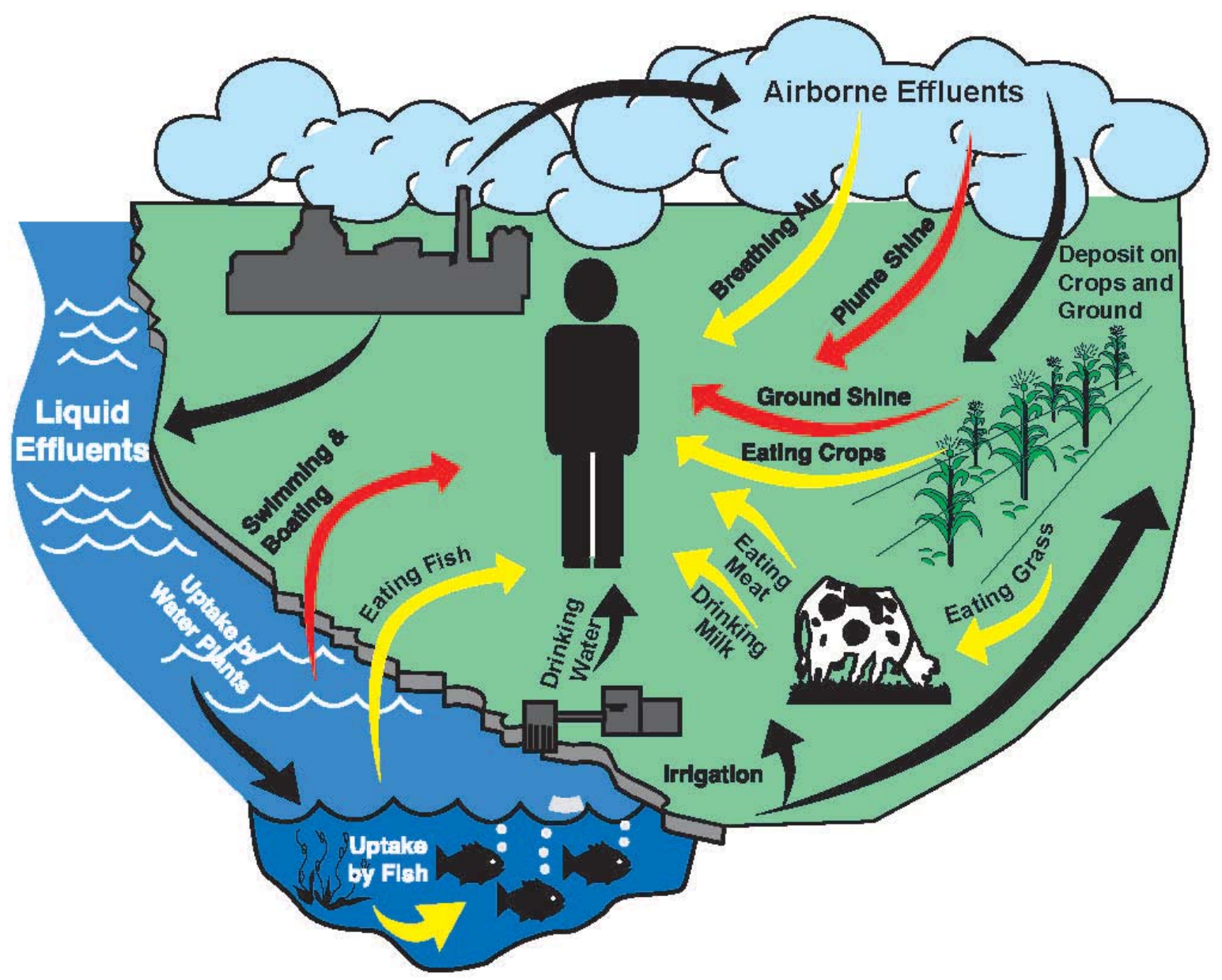

Figure 6-1 Exposure Pathways to Humans from Atmospheric and Liquid Effluents

\section{Calculating Dose}

DOE Order 458.1 (DOE, 2011) states that compliance with the DOE annual dose limit of $100 \mathrm{mrem} / \mathrm{yr}(1 \mathrm{mSv} / \mathrm{yr})$ to a member of the public may be demonstrated by calculating dose to the maximally exposed individual (MEI) or to a representative person. Historically, the MEI concept was used for dose compliance at SRS using adult dose coefficients and adult male usage parameters. Beginning in 2012, SRS now uses the representative person concept for dose compliance.

In DOE Order 458.1, the representative person is defined as an individual receiving a dose that is representative of the more highly exposed individuals in the population. This term is equivalent of, and replaces, "average member of the critical group." However, in International Commission on Radiological Protection (ICRP) Report 101 (ICRP, 2006), the definition is extended to include the ... average value for the more highly exposed group OR the 95th percentile of appropriate national or regional data. The OR is highlighted for emphasis. At SRS, the representative person who is at the 95th percentile of national usage data is now used as a replacement for the MEI. 
The representative person dose is based on reference person usage parameters (at the 95th percentile of national and regional data) developed specifically for SRS. The applicable national and regional data used are from the "EPA Exposure Factor Handbook," 2011 Edition (EPA, 2011).

The reference person is weighted based on sex and age and this weighting is based on the six age groups documented in Report 89 (ICRP, 2002): Infant (0 years), 1 year, 5 years, 10 years, 15 years, and Adult. The various age- and gender-specific intake rates from EPA (2011) were proportioned to correspond with these respective age groupings. SRS developed usage parameters at the 50th percentile, which are used in calculating dose to a "typical" person for determining collective doses. The SRS-specific reference and typical person usage parameters were developed by Stone and Jannik (2013) and are provided in Table 6-1, along with a comparison to the pre-2012 usage parameters. In general, the representative person doses will be higher than the previous MEI doses and the typical person doses will be lower than the average adult doses. All other applicable land and water use parameters used in the dose calculations are documented in the "Land and Water Use Characteristics and Human Health Input Parameters for Use in Environmental Dosimetry and Risk Assessments at the Savannah River Site" (Jannik et al., 2010). These parameters include local characteristics of food production, river recreational activities, and other human usage parameters required in the SRS dosimetry models. In addition, SRS documents the preferred elemental bioaccumulation and transfer factors to be used in human health exposure calculations in this report. Data Tables 6-1 and 6-2 provides a summary of the site-specific input parameters that are the most important to the dose calculations for the liquid and airborne pathways, respectively.

Table 6-1 Comparison of References and Typical Person Usage Parameters with Pre-2012 Usage Parameters

\begin{tabular}{|l|c|c|c|c|}
\hline \multicolumn{5}{|c|}{$95 \%$} \\
\hline Uir & Unit & Reference Person & Pre-2012 MEI & Difference \\
\hline Water & $\mathrm{m}^{3} / \mathrm{y}$ & 6,400 & 8,000 & $-20.0 \%$ \\
\hline Meat & $\mathrm{L} / \mathrm{y}$ & 800 & 730 & $9.6 \%$ \\
\hline Leafy Vegetables & $\mathrm{kg} / \mathrm{y}$ & 81 & 81 & $0.0 \%$ \\
\hline Other Produce & $\mathrm{kg} / \mathrm{y}$ & 31 & 43 & $-27.9 \%$ \\
\hline Milk/Dairy & $\mathrm{kg} / \mathrm{y}$ & 289 & 276 & $0.5 \%$ \\
\hline Freshwater Fish & $\mathrm{L} / \mathrm{y}$ & 260 & 230 & $13 \%$ \\
\hline Saltwater Invertebrate & $\mathrm{kg} / \mathrm{y}$ & 24 & 19 & $26.3 \%$ \\
\hline & $\mathrm{kg} / \mathrm{y}$ & 9.0 & 8 & $12.5 \%$ \\
\hline & \multicolumn{5}{|c|}{$50 \%$} & & \\
\hline Air & Unit & Typical Person & Pre-2012 Avg. & Difference \\
\hline Water & & & Adult & \\
\hline Meat & $\mathrm{m} / \mathrm{y}$ & 5,000 & 5,548 & $-9.9 \%$ \\
\hline Leafy Vegetable & $\mathrm{L} / \mathrm{y}$ & 300 & 337 & $-11.0 \%$ \\
\hline Other Produce & $\mathrm{kg} / \mathrm{y}$ & 32 & 43 & $-26.3 \%$ \\
\hline Milk/Dairy & $\mathrm{kg} / \mathrm{y}$ & 11 & 21 & $-47.6 \%$ \\
\hline Freshwater Fish & $\mathrm{kg} / \mathrm{y}$ & 89 & 163 & $-45.4 \%$ \\
\hline Saltwater Invertebrate & $\mathrm{L} / \mathrm{y}$ & 69 & 120 & $-42.3 \%$ \\
\hline
\end{tabular}


For determining compliance with DOE public dose requirements, SRS calculates the potential offsite doses from SRS effluent releases of radioactive materials (atmospheric and liquid) for the following scenarios:

- Representative person living at the SRS boundary, and

- Population living within a 50-mile (80-kilometer [km]) radius of SRS.

To demonstrate compliance with the DOE Order 458.1 all-pathway dose standard of $100 \mathrm{mrem} / \mathrm{yr}$, SRS conservatively combines the airborne pathway and liquid pathway dose estimates, even though the two doses are calculated for hypothetical individuals residing at different geographic locations.

For SRS dose calculations, unspecified alpha releases were treated as plutonium-239, and unspecified beta releases, were treated as strontium-90. These radionuclides have the highest dose factors of the alpha- and beta-emitters, respectively, commonly measured in SRS waste streams.

SRS has assessed the potential effects of routine radioactive releases annually since operations began. Since 1972, SRS has published annual offsite dose estimates in Site environmental reports made available to the public. For all routine environmental dose calculations performed since 1978, SRS has used environmental transport models based on codes developed by the Nuclear Regulatory Commission (NRC) (NRC, 1977). The NRC based transport models use DOE accepted methods, consider all significant exposure pathways, and permit detailed analysis of the effects of routine operations. At SRS, the MAXDOSE- SR and POPDOSE-SR codes are used for atmospheric releases and LADTAP XL ${ }^{\odot}$ is used for liquid releases. These models are described in the SRS EDAM (2010).

From 1988 through 2009, SRS used the internal and external dose conversion factors provided in DOE [1988]. In 2010, the internal dose conversion factors were updated to use the dose factors from ICRP Publication 72, (ICRP, 1996) and the external dose conversion factors were updated to the dose factors provided in Federal Guidance Report 12, (US Environmental Protection Agency [EPA], 1993). Beginning in 2012, the dose to a representative person is based on (1) the SRS-specific reference person usage parameters at the 95th percentile of appropriate national or regional data, which are documented in Stone and Jannik (2013), (2) the reference person (gender and age averaged) ingestion and inhalation dose coefficients provided in DOE Derived Concentration Technical Standard, DOESTD-1196-2011 (DOE, 2011a), and (3) the external dose coefficients provided in the DC_PAK3 toolbox, which can be accessed at http://www.epa.gov/rpdweb00/federal/techdocs.html. Currently, there are no age specific external dose factors available.

\section{Meteorological Database}

Potential offsite doses from releases of radioactivity to the atmosphere were calculated with quality-assured meteorological data for A Area, K Area (for combined releases from C Area, K Area, and L Area), and H Area (for combined releases from all other areas). The meteorological databases for the years 2002-2006, reflecting the most recent fiveyear compilation period reported, are provided in Data Table 6-3.

To show compliance with EPA National Emission Standards for Hazardous Air Pollutants (NESHAP) regulations (EPA, 2002a), only the H Area meteorological database was used in the calculations because the EPA-required dosimetry code (CAP88 PC [Personal Computer] version 3.0, henceforth referred to simply as CAP88 PC) is limited to a single release location.

\section{Population Database and Distribution}

Collective (population) doses from atmospheric releases are calculated for the population within a 50-mile radius of SRS. Based on the U.S. Census Bureau's 2010 data, the population within a 50-mile radius of the center of SRS is 781,060 . This translates to an average population density of about 104 people per square mile outside the SRS boundary, with the largest concentration in the Augusta metropolitan area. The population distribution around SRS is provided in Data Table 6-4. 
Some of the collective doses resulting from SRS liquid releases are calculated for the populations served by the City of Savannah Industrial and Domestic Water Supply Plant (Savannah I\&D), near Port Wentworth, Georgia, and by the Beaufort-Jasper Water and Sewer Authority's (BJWSA) Chelsea and Purrysburg Water Treatment Plants, both near Beaufort, South Carolina. According to the treatment plant operators, the population served by the Savannah I\&D facility during 2012 was 26,300 persons, while the population served by the BJWSA Chelsea facility was 77,000 persons and by the BJWSA Purrysburg facility, 58,000 persons. The total population dose resulting from routine SRS liquid releases is the sum of five contributing categories: (1) BJWSA water consumers, (2) Savannah I\&D water consumers, (3) consumption of fish and invertebrates of Savannah River origin, (4) recreational activities on the Savannah River, and (5) irrigation of foodstuffs using river water near River Mile 118.8.

\section{River Flow Rate Data}

Savannah River flow rates, recorded at a gauging station near River Mile 118.8 (U.S. Highway 301 bridge), are based on the measured water elevation. The river flow rates measured at this location from 1954 through 2012 are provided in Data Table 6-5 and show that the mean river flow rate for these years is 10,050 cubic feet per second (cfs). However, these data are not used directly in the SRS dose calculations. "Effective" flow rates are used instead and they are based on (1) the measured annual release of tritium and (2) the annual average tritium concentrations measured from River Mile 118.8 and from the three downriver water treatment plants. The effective river flow rate calculations are shown in Data Table 6-6. The use of effective flow rates in the dose calculations is more conservative than the use of measured flow rates because it accounts for less dilution.

For 2012, the River Mile 118.8 calculated (effective) flow rate of 3,579 cfs was used in the dose calculations. This flow rate was about $17 \%$ less than the 2011 effective flow rate of 4,329 cfs. For comparison, the 2012 annual average flow rate, as measured by the U.S. Geological Survey (USGS), was 4,570 cfs. This was the lowest measured annual river flow rate since operations began at SRS in 1954 and it indicates that 2012 was a severe drought year in the Savannah River basin. The 2012 calculated effective flow rates were 5,089 cfs for the Savannah I\&D facility, 4,671 cfs for the BJWSA Chelsea facility, and 4,477 cfs for the BJWSA Purrysburg facility.

\section{Dose Calculation Results}

\section{Liquid Pathway}

\section{Liquid Release Source Terms}

The 2012 radioactive liquid release quantities used as the source term in SRS dose calculations, which are discussed in Chapter 4, "Effluent Monitoring," and Chapter 5, "Environmental Surveillance," are shown by radionuclide in Table 6-2, and shown by Site streams in Data Table 6-7. Data Table 6-8 provides a five-year history of SRS liquid radioactive releases. Tritium accounts for more than $99 \%$ of the total amount of radioactivity released from the Site to the Savannah River. In 2012, SRS released a total of 746 curies of tritium to the river, a 21\% decrease from the 2011 amount of 942 curies.

In the past, the total amount of tritium in SRS dose calculations was based on the measured tritium concentration at River Mile 118.8. However, the total from this location includes the tritium releases from Georgia Power Company's Vogtle Electric Generating Plant (VEGP). Since 2006, doses have been calculated and documented in this report using SRS-only releases. A separate dose calculation is performed (for information only) that includes the total amount of tritium (SRS plus VEGP), which in 2012 was 1,927 curies (746 curies from SRS and 1,181 curies from VEGP). 
Table 6-2 2012 Radioactive Liquid Release Source Term and 12-Month Average Downriver Radionuclide Concentrations Compared to the EPA's Drinking Water Maximum Contaminant Levels (MCL)

\begin{tabular}{|c|c|c|c|c|c|c|}
\hline \multirow{2}{*}{ Nuclide } & \multirow{2}{*}{$\begin{array}{l}\text { Activity } \\
\text { Released }\end{array}$} & \multicolumn{5}{|c|}{ 12-Month Average Concentration (pCi/L) } \\
\hline & & $\begin{array}{l}\text { Below } \\
\text { SRS }^{\text {a }}\end{array}$ & $\begin{array}{l}\text { BJWSA } \\
\text { Chelsea }^{\text {b }}\end{array}$ & $\begin{array}{c}\text { BJWSA } \\
\text { Purrysburg } \\
\end{array}$ & $\begin{array}{c}\text { Savannah } \\
\text { I\&D } \\
\end{array}$ & EPA MCL ${ }^{e}$ \\
\hline H-3 ${ }^{d}$ & $1.93 \mathrm{E}+03$ & $6.03 \mathrm{E}+02$ & $4.62 \mathrm{E}+02$ & $4.82 \mathrm{E}+02$ & $4.24 \mathrm{E}+02$ & $2.00 \mathrm{E}+04$ \\
\hline C-14 & $4.33 \mathrm{E}-03$ & $1.35 \mathrm{E}-03$ & $1.04 \mathrm{E}-03$ & $1.08 \mathrm{E}-03$ & $9.53 \mathrm{E}-04$ & $2.00 \mathrm{E}+03$ \\
\hline Sr-90 & $1.81 \mathrm{E}-02$ & $5.66 \mathrm{E}-03$ & $4.34 \mathrm{E}-03$ & $4.53 \mathrm{E}-03$ & $3.98 \mathrm{E}-03$ & $8.00 \mathrm{E}+00$ \\
\hline Tc-99 & $1.09 \mathrm{E}-02$ & $3.41 \mathrm{E}-03$ & $2.61 \mathrm{E}-03$ & $2.73 \mathrm{E}-03$ & $2.40 \mathrm{E}-03$ & $9.00 \mathrm{E}+02$ \\
\hline I-129 & $1.33 \mathrm{E}-02$ & $4.16 \mathrm{E}-03$ & $3.19 \mathrm{E}-03$ & $3.33 \mathrm{E}-03$ & $2.93 \mathrm{E}-03$ & $1.00 \mathrm{E}+00$ \\
\hline Cs-137 & $5.09 \mathrm{E}-02$ & $1.59 \mathrm{E}-02$ & $1.22 \mathrm{E}-02$ & $1.27 \mathrm{E}-02$ & $1.12 \mathrm{E}-02$ & $2.00 \mathrm{E}+02$ \\
\hline $\mathrm{U}-234$ & $7.48 \mathrm{E}-02$ & $2.34 \mathrm{E}-02$ & $1.79 \mathrm{E}-02$ & $1.87 \mathrm{E}-02$ & $1.65 \mathrm{E}-02$ & $1.03 \mathrm{E}+01$ \\
\hline U-235 & $3.84 \mathrm{E}-03$ & $1.20 \mathrm{E}-03$ & $9.20 \mathrm{E}-04$ & $9.60 \mathrm{E}-04$ & $8.45 \mathrm{E}-04$ & $4.67 \mathrm{E}-01$ \\
\hline U-238 & $7.73 \mathrm{E}-02$ & $2.42 \mathrm{E}-02$ & $1.85 \mathrm{E}-02$ & $1.93 \mathrm{E}-02$ & $1.70 \mathrm{E}-02$ & $1.00 \mathrm{E}+01$ \\
\hline Np-237 & $5.14 \mathrm{E}-06$ & $1.61 \mathrm{E}-06$ & $1.23 \mathrm{E}-06$ & $1.29 \mathrm{E}-06$ & $1.13 \mathrm{E}-06$ & $1.50 \mathrm{E}+01$ \\
\hline Pu-238 & $6.79 \mathrm{E}-04$ & $2.12 \mathrm{E}-04$ & $1.63 \mathrm{E}-04$ & $1.70 \mathrm{E}-04$ & $1.49 \mathrm{E}-04$ & $1.50 \mathrm{E}+01$ \\
\hline Pu-239 & 5.69E-05 & $1.78 \mathrm{E}-05$ & $1.36 \mathrm{E}-05$ & $1.42 \mathrm{E}-05$ & $1.25 \mathrm{E}-05$ & $1.50 \mathrm{E}+01$ \\
\hline Am-241 & $3.93 \mathrm{E}-03$ & $1.23 \mathrm{E}-03$ & $9.42 \mathrm{E}-04$ & $9.83 \mathrm{E}-04$ & $8.65 \mathrm{E}-04$ & $1.50 \mathrm{E}+01$ \\
\hline Cm-244 & $6.82 \mathrm{E}-04$ & $2.13 \mathrm{E}-04$ & $1.63 \mathrm{E}-04$ & $1.71 \mathrm{E}-04$ & $1.50 \mathrm{E}-04$ & $1.50 \mathrm{E}+01$ \\
\hline Alphaf $^{f}$ & $1.40 \mathrm{E}-02$ & $4.38 \mathrm{E}-03$ & $3.36 \mathrm{E}-03$ & $3.50 \mathrm{E}-03$ & $3.08 \mathrm{E}-03$ & $1.50 \mathrm{E}+01$ \\
\hline Beta $^{g}$ & 4.88E-02 & $1.53 \mathrm{E}-02$ & $1.17 \mathrm{E}-02$ & $1.22 \mathrm{E}-02$ & $1.07 \mathrm{E}-02$ & $8.00 \mathrm{E}+00$ \\
\hline \multicolumn{7}{|c|}{$\begin{array}{l}\text { a Near River Mile 118.8, downriver of SRS at the U.S. Highway } 301 \text { bridge } \\
\text { b Beaufort-Jasper, South Carolina, drinking water } \\
\text { c Port Wentworth, Georgia, drinking water } \\
\text { d The tritium concentrations and source term are based on actual measurements of the Savannah River water at the } \\
\text { various locations. They include contributions from VEGP. All other radionuclide concentrations are calculated based } \\
\text { on the effective river flow rate. } \\
\text { e MCLs for uranium based on radioisotope specific activity * } 30 \mu \mathrm{g} / \mathrm{L} * \text { isotopic abundance } \\
\text { f, g For dose calculations and MCL comparisons, unspecified alpha and beta releases are assumed to be Pu-239 and Sr-90, } \\
\text { respectively }\end{array}$} \\
\hline
\end{tabular}

\section{Radionuclide Concentrations in Savannah River Water, Drinking Water, and Fish}

The concentrations of tritium in Savannah River water and cesium-137 in Savannah River fish are measured at several locations along the river for use in dose determinations and model comparisons. The amounts of all other radionuclides released from SRS are so small that their concentration in the Savannah River usually cannot be detected using conventional analytical techniques. Therefore, their concentrations in the river are calculated using the LADTAP XL ${ }^{\circ}$ code, based on the annual release amounts and on the applicable effective flow rate.

Radionuclide Concentrations in River Water and Treated Drinking Water - The measured concentrations of tritium in the Savannah River near River Mile 118.8 and at the Savannah I\&D and BJWSA water treatment facilities are in Table 6-2, as are the calculated concentrations for the other released radionuclides. These downriver tritium concentrations include tritium releases from SRS and the neighboring VEGP. Also shown in Table 6-2 is a comparison of these concentrations to the EPA Safe Drinking Water Act, 40 CFR 141 (EPA, 2000) maximum contaminant level (MCL) for each radionuclide.

In 2012, the 12-month average tritium concentration measured in Savannah River water near River Mile 118.8 was 603 picocuries per liter $(\mathrm{pCi} / \mathrm{L})$. This reflects a slight increase from the $598 \mathrm{pCi} / \mathrm{L}$ measured in 2011 . Even though the amount of tritium released to the Savannah River from SRS and VEGP decreased 17\% in 2012, there was an increase 
in the annual average tritium concentration because of the 17\% decrease in river flow from 2011 to 2012 . The 2012 concentrations at the BJWSA Chelsea $(462 \mathrm{pCi} / \mathrm{L})$ and Purrysburg $(482 \mathrm{pCi} / \mathrm{L})$ facilities and at the Savannah I\&D $(424 \mathrm{pCi} / \mathrm{L})$ water treatment plant were proportionately lower than in 2011 and remained well below the EPA drinking water MCL of $20,000 \mathrm{pCi} / \mathrm{L}$.

Table 6-2 indicates that all individual radionuclide concentrations at the three downriver community drinking water systems, as well as at River Mile 118.8, were below the EPA MCLs. Because more than one radionuclide is released from SRS, the sum of the fractions of the reported concentration of each radionuclide divided by its corresponding MCL must not exceed 1.0. As shown in Data Table 6-9, the sums of the fractions were 0.0342 at the BJWSA Chelsea facility, 0.0357 at the BJSWA Purrysburg facility, and 0.0314 at the Savannah I\&D facility. These are below the 1.0 sum-of-the-fractions requirement.

For 2012, the sum of the fractions at the River Mile 118.8 location was 0.0447 . This is provided only for comparison because River Mile 118.8 is not a community drinking water system location.

Radionuclide Concentrations in Fish - At SRS, an important dose pathway for the representative person is from the consumption of fish. Fish exhibit a high degree of bioaccumulation for certain elements. For the element cesium (including radioactive isotopes of cesium), the bioaccumulation factor for Savannah River fish is 3,000 meaning that the concentration of cesium in fish flesh is about 3,000 times the concentration of cesium found in the water in which the fish live (Carlton et al., 1994).

Because of this high bioaccumulation factor, cesium-137 is detected more easily in fish flesh than in river water. Therefore, the fish pathway dose from cesium-137 normally is based directly on the radioanalysis of the fish collected near River Mile 118.8, the assumed location of the hypothetical representative person. However, as shown in Data Table 6-10, the LADTAP XL dose model calculated concentration of cesium-137 in fish, based on measured SRS effluent releases, was determined to be more than the actual measured concentration in fish. To be conservative, the higher calculated concentration of cesium-137 in fish $(0.0478 \mathrm{pCi} / \mathrm{g})$ was used in the 2012 dose determinations.

\section{Dose to the Representative Person}

No known large-scale uses of Savannah River water downstream of SRS exist for agricultural irrigation purposes. However, the potential for agricultural irrigation does exist, especially for individual garden use. Therefore, beginning in 2011, the doses from the irrigation pathway are included in the totals for the SRS representative person and collective doses.

As shown in Data Table 6-11, the 2012 dose to the representative person from all liquid pathways except irrigation was estimated at 0.10 mrem $(0.0010$ millisievert $(\mathrm{mSv}))$, which was about $19 \%$ more than the comparable dose in 2011 of $0.084 \mathrm{mrem}(0.00084 \mathrm{mSv})$. As shown in Data Table 6-16, the irrigation pathway representative person dose was estimated to be $0.13 \mathrm{mrem}(0.0013 \mathrm{mSv})$, which was about $41 \%$ more than the 2011 dose of $0.092 \mathrm{mrem}(0.00092$ $\mathrm{mSv}$ ). These increases are mainly attributed to the differences in the previous adult MEI and the new reference person usage parameters and dose coefficients (Stone and Jannik, 2013). Adding these two doses together leads to a total liquid, all-pathway dose of $0.23 \mathrm{mrem}(0.0023 \mathrm{mSv})$. Table $6-3$ shows this total dose is $0.23 \%$ of the all-pathway dose standard for annual exposure of 100 mrem (1 mSv). A five-year history of SRS doses is provided in Data Table 6-12.

Table 6-3 Potential Dose to the Representative Person from SRS Liquid Releases in 2012

\begin{tabular}{|l|c|c|c|}
\hline & \multicolumn{1}{|c|}{$\begin{array}{c}\text { Committed Dose } \\
\text { (mrem) }\end{array}$} & $\begin{array}{c}\text { Applicable Standard } \\
\text { (mrem) }\end{array}$ & Percent of Standard (\%) \\
\hline Near Site Boundary (All Liquid Pathways) & \\
\hline $\begin{array}{l}\text { All Liquid Pathways } \\
\text { Except Irrigation }\end{array}$ & 0.10 & & 0.23 \\
\hline Irrigation Pathways & 0.13 & $100^{\mathrm{a}}$ & \\
\hline Total Pathways & 0.23 & & \\
\hline${ }^{a}$ All-pathway dose standard: $100 \mathrm{mrem} / \mathrm{yr}$ (DOE Order 458.1) \\
\hline
\end{tabular}




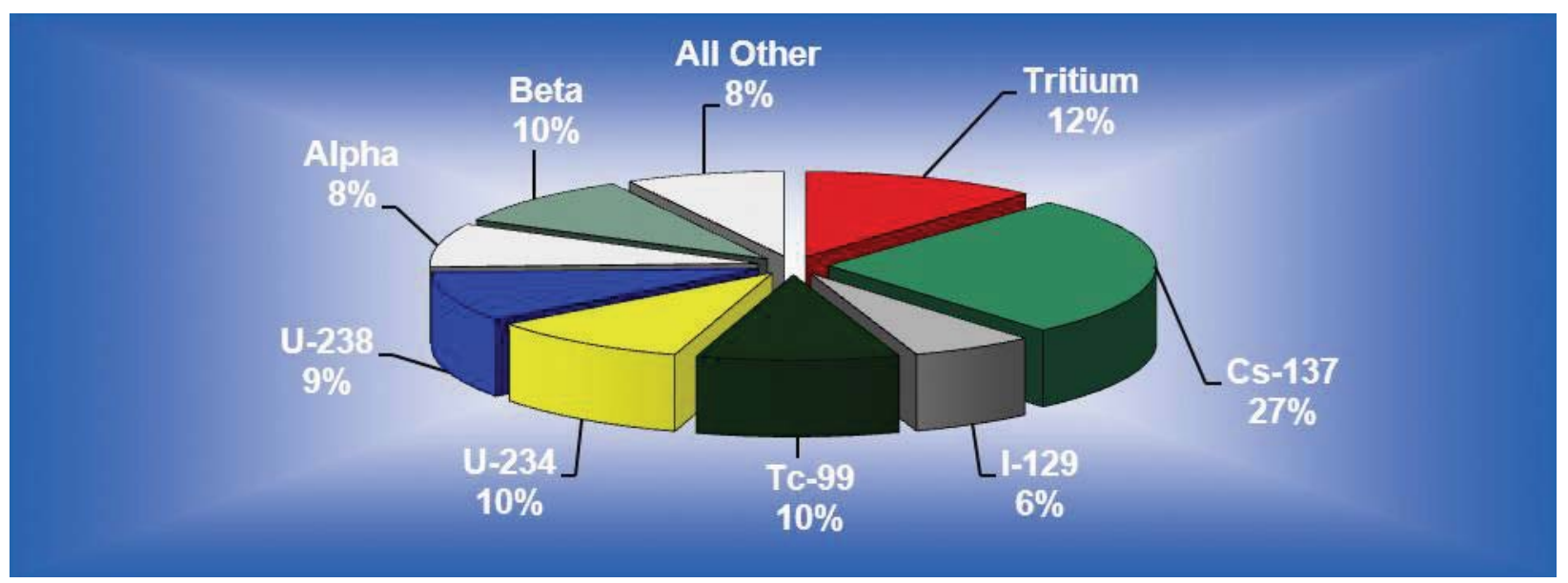

Figure 6-2 Radionuclide Contributions to the 2012 SRS Total Liquid Pathway Dose of 0.23 mrem (0.0023mSv)

About $57 \%$ of the 2012 total dose to the representative person resulted from the irrigation pathway (ingestion of meat, milk, and vegetables). The fish consumption pathway accounted for $29 \%$ and the drinking water pathway, $14 \%$. As shown in Figure 6-2, cesium-137 (27\%), tritium oxide (12\%), and unidentified beta, technetium-99, and uranium-234 ( $10 \%$ each) were the major radionuclides contributing to the total liquid pathway dose. "All Other" individual radionuclides contributed less than $5 \%$ and collectively $8 \%$ to the total liquid pathway dose (Data Table 6-11).

Using the 2012 total Savannah River tritium source term (which includes SRS and VEGP releases) of 1,927 curies, the representative person dose (including the irrigation pathway) was calculated to be $0.27 \mathrm{mrem}(0.0027 \mathrm{mSv})$. This dose, provided for information only, is about $29 \%$ more than the 2011 comparable dose of $0.21 \mathrm{mrem}(0.0021 \mathrm{mSv})$.

\section{Drinking Water Pathway Dose}

People living downriver of SRS may receive some dose by consuming drinking water that contains radioactivity released from the Site. Tritium in downriver drinking water represented the majority of the dose (about $46 \%$ ) received by customers of the three downriver water treatment plants (see Data Tables 6-13 and 6-14).

Based on SRS-only releases, the maximum potential drinking water dose during 2012 was determined to be 0.025 mrem $(0.00025 \mathrm{mSv})$, about $25 \%$ more than the 2011 dose of $0.020 \mathrm{mrem}(0.00020 \mathrm{mSv})$ (Data Table 6-12). Using the SRS-plus-VEGP total tritium source term of 1,927 curies, the maximum drinking water dose in 2012 was calculated to be $0.044 \mathrm{mrem}(0.00044 \mathrm{mSv})$. In DOE Order 458.1, there is not a separate drinking water dose standard. Offsite public drinking water systems are regulated under EPA 40 CFR 141 (EPA, 2000).

\section{Collective (Population) Dose}

The collective drinking water consumption dose is calculated for the discrete population groups served by the BJWSA and Savannah I\&D water treatment plants. Collective doses from agricultural irrigation were calculated assuming that 1,000 acres of land were devoted to each of the major food types grown in the SRS area (vegetables, milk, and meat).

It is assumed that all the food produced on these 1,000 -acre parcels is consumed by the population $(781,060)$ within 50 miles of SRS. The collective dose from other pathways is calculated for a diffuse population that makes use of the Savannah River; however, this population cannot be described as being in a specific geographical location. As shown in Data Table 6-15, the collective dose from all pathways except irrigation was 1.9 person-rem ( 0.019 person-Sv) in 2012. As shown in Data Table 6-16, the collective dose from the irrigation pathway also was 1.9 person-rem $(0.019$ person-Sv). Adding these two doses together leads to a total all pathway collective dose of 3.8 person-rem (0.038 person-Sv). This is about $23 \%$ more than the comparable 2011 collective dose of 3.1 person-rem ( 0.031 person-Sv). This increase is mainly attributed to the differences in the previous adult MEI and the new reference person dose coefficients (Stone and Jannik, 2013). 


\section{Air Pathway}

\section{Atmospheric Source Terms}

The 2012 radioactive atmospheric release quantities used as the source term in SRS dose calculations are discussed in Chapter 4, "Effluent Monitoring," and are in Data Table 6-17. Estimates of unmonitored diffuse and fugitive sources were included in the atmospheric source term, as required, for demonstrating compliance with EPA NESHAP regulations. Data Table 6-18 provides a five-year history of SRS atmospheric releases.

\section{Atmospheric Concentrations}

Calculated radionuclide concentrations instead of measured concentrations are used for dose determinations because most radionuclides released from SRS were not detected (using conventional analytical methods) in the air samples collected at the Site perimeter and offsite locations. However, the concentrations of tritium oxide at the Site perimeter locations usually are detected and are compared with calculated concentrations as a verification of the dose models in Data Table 6-19.

\section{Dose to the Representative Person}

The 2012 estimated dose from atmospheric releases to the representative person (calculated with MAXDOSE-SR) was $0.027 \mathrm{mrem}(0.00027 \mathrm{mSv}), 0.27 \%$ of the DOE Order 458.1 air pathway standard of 10 mrem per year. Table $6-4$ compares the representative person dose with the DOE standard. The 2012 dose was about $16 \%$ less than the 2011 dose of $0.032 \mathrm{mrem}(0.00032 \mathrm{mSv})$. This decrease is attributed to the decrease in the Site's tritium releases from 2011 to 2012 (refer to Chapter 4, "Effluent Monitoring" for additional information) and to the decrease in reference person breathing rate $\left(6,400 \mathrm{~m}^{3} / \mathrm{y}\right)$ as compared to the previous adult MEI breathing rate of $8,000 \mathrm{~m}^{3} / \mathrm{y}$ (Table 6-1). A five-year history of SRS air pathway doses is in Data Table 6-12.

Table 6-4 Potential Doses to the Representative Person and to the MEI from SRS Atmospheric Releases in 2012 and Comparison to the Applicable Dose Standard

\begin{tabular}{|l|c|c|}
\hline & MAXDOSE-SR & CAP88-PC NESHAP \\
\hline Calculated dose (mrem) & 0.027 & 0.040 \\
\hline Applicable Standard (mrem) & $10^{\mathrm{a}}$ & $10^{\mathrm{b}}$ \\
\hline Percent of Standard (\%) & 0.27 & 0.40 \\
\hline $\begin{array}{l}\text { aDOE: DOE Order 458.1 } \\
\text { bEPA: (NESHAP) 40 CFR 61, Subpart H }\end{array}$ & \\
\hline
\end{tabular}




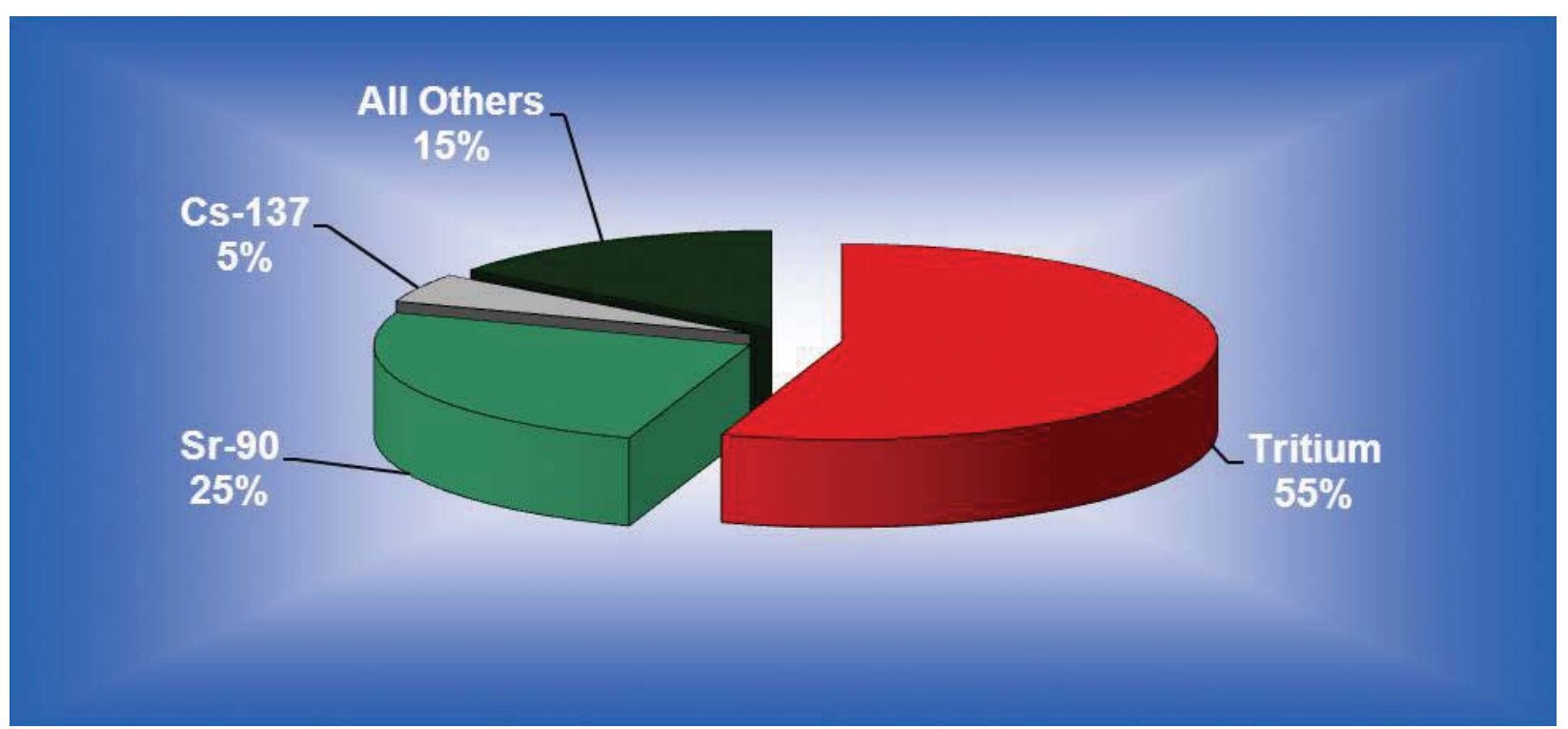

Figure 6-3 Radionuclide Contributions to the 2012 SRS Air Pathway Dose of $0.027 \mathrm{mrem}(0.00027 \mathrm{mSv})$

The 2012 atmospheric doses by both radionuclide and pathway are provided in Data Table 6-20. As shown in Figure 6-3, tritium oxide releases accounted for about $55 \%$ of the dose to the representative person, strontium- 90 releases accounted for about $25 \%$, and cesium- 137 accounted for about $5 \%$ of the dose. No other individual radionuclide accounted for more than $5 \%$ of the representative person dose.

The major pathways contributing to the representative person dose from atmospheric releases were vegetation consumption (44\%), inhalation (27\%), and cow milk consumption (16\%). As shown in Data Table 6-21 and in Data Map Figure 16, the due north sector of the Site was the location of the highest dose to the representative person.

Because of the potential in the SRS vicinity for exposure to goat milk, additional calculations of the dose to the representative person were performed substituting goat milk for the customary cow milk pathway. As shown in Data Table $6-22$, the potential dose to the representative person using the goat milk pathway was estimated to be $0.030 \mathrm{mrem}$ $(0.00030 \mathrm{mSv})$. This dose is provided for reference only.

\section{Collective (Population) Dose}

The air-pathway collective dose is calculated for the entire 781,060 population living within 50 miles of SRS. The population distribution around SRS is provided in Data Table 6-4. In 2012, the airborne-pathway collective dose (calculated with POPDOSE-SR) was estimated at 0.76 person-rem ( 0.0076 person-Sv), less than $0.01 \%$ of the annual collective dose received from natural sources of radiation (about 234,000 person-rem).

The 2012 air-pathway collective doses by radionuclide and pathway are provided in Data Table 6-23. Tritium oxide releases accounted for about $69 \%$ of the collective dose. The 2012 collective dose was about $37 \%$ less than the 2011 collective dose of 1.2 person-rem $(0.012$ person-Sv). This decrease is mainly attributed to the decrease in tritium releases from 2011 to 2012 and to the reduction in usage parameters for the new "typical" person as compared to the previous average adult male (Table 6-1).

\section{NESHAP Compliance}

To demonstrate compliance with NESHAP regulations (EPA, 2002a), MEI and collective doses were calculated using (1) the CAP88 PC version 3.0 computer code (version dated February 9, 2013), (2) the 2012 airborne-release source term (Data Table 6-24), and (3) site-specific input parameters (Data Table 6-25). EPA requires the use of the adult MEI and does not allow use of the reference person concept at this time. Most input parameters in CAP88 PC are hard coded in the program and cannot be changed without specific EPA approval. The SRS specific parameters used are in Data Table 6-25. 
In 2011, SRS began using the PC version of the CAP88 code. Previously, the mainframe version of the code was used, but a mainframe computer is no longer available for these calculations at SRS. For 2011, the CAP88 PC version 3.0 code dated December 9, 2007 was used. However, after the 2011 SRS annual report was issued, SRS discovered that the December 9, 2007 version of the code was not producing expected results when performing calculations for multiple co-located stacks. EPA corrected this issue in the February 9, 2013 version of the CAP88 PC version 3.0 code. Refer to Appendix B, "Errata" in this report for details on this issue and for the changes in the reported 2011 NESHAP doses.

For 2012, using the CAP88 PC code, the MEI dose was estimated at 0.040 mrem $(0.00040 \mathrm{mSv}), 0.40 \%$ of the 10 $\mathrm{mrem} / \mathrm{yr}$ EPA standard, as shown in Table 6-4. The 2012 doses by radionuclide are provided in Data Table 6-26. Tritium oxide releases accounted for about $65 \%$ of this dose and strontium- 90 accounted for $20 \%$.

The 2012 NESHAP compliance dose was about $29 \%$ less than the corrected 2011 dose of 0.056 mrem ( $0.00056 \mathrm{mSv})$. SRS mainly attributes the decrease to the relatively large decrease in tritium oxide releases from the Site in 2012 as compared to 2011 (refer to Chapter 4, "Effluent Monitoring," for additional information).

For NESHAP, the dose from diffuse and fugitive releases is required to be reported separately. Data Table 6-27 shows the MEI dose from diffuse and fugitive releases was about $0.014 \mathrm{mrem}(0.00014 \mathrm{mSv})$ and it accounts for $35 \%$ of the total 2012 MEI dose.

The CAP88 PC-determined collective dose for 2012 was estimated at 3.7 person-rem $(0.037$ person-Sv), which is about $27 \%$ less than the corrected 2011 collective dose of 5.1 person-rem $(0.051$ person-Sv). Tritium oxide releases accounted for about $67 \%$ and strontium- 90 accounted for about $22 \%$ of this dose. Comparisons (by pathway and major radionuclides) of the CAP88 PC-determined MEI and collective doses with the MAXDOSE-SR and POPDOSE-SR representative person doses are provided in Data Tables 6-28 and 6-29, respectively. As shown in these tables, the CAP88 PC code estimates a higher dose than the two SRS codes because the CAP88 PC code conservatively (1) doubles the ingestion dose coefficient for tritium oxide, (2) uses the tritium oxide ingestion dose coefficients for elemental tritium, and (3) assigns the adult male MEI consumption and usage rates to all members of the public.

\section{All-Pathway Dose}

To demonstrate compliance with the DOE Order 458.1 all-pathway dose standard of $100 \mathrm{mrem} / \mathrm{yr}$, SRS conservatively combines the representative person airborne all-pathway and liquid all-pathway dose estimates, even though the two doses are calculated for hypothetical individuals residing at different geographic locations. As previously discussed, the SRS all-pathway liquid dose includes the irrigation pathway dose estimate.

For 2012, the potential representative person all-pathway dose was $0.26 \mathrm{mrem}(0.0026 \mathrm{mSv}), 0.027 \mathrm{mrem}$ from air pathways plus $0.10 \mathrm{mrem}$ from the standard liquid pathways and $0.13 \mathrm{mrem}$ from the irrigation pathways. The allpathway dose is $0.26 \%$ of the $100 \mathrm{mrem} / \mathrm{yr}$ DOE dose standard. The 2012 all-pathway dose is about $24 \%$ more than the reported 2011 total dose of $0.21 \mathrm{mrem}(0.0021 \mathrm{mSv})$. This increase is mainly attributed to the differences in the previous adult MEI and the new reference person usage parameters and dose coefficients (Stone and Jannik 2013). Figure 6-4 graphically shows a ten-year history of SRS's all-pathway (airborne pathway plus liquid pathway) doses to the MEI/representative person. A five-year history of SRS all-pathway doses is in Data Table 6-12. 


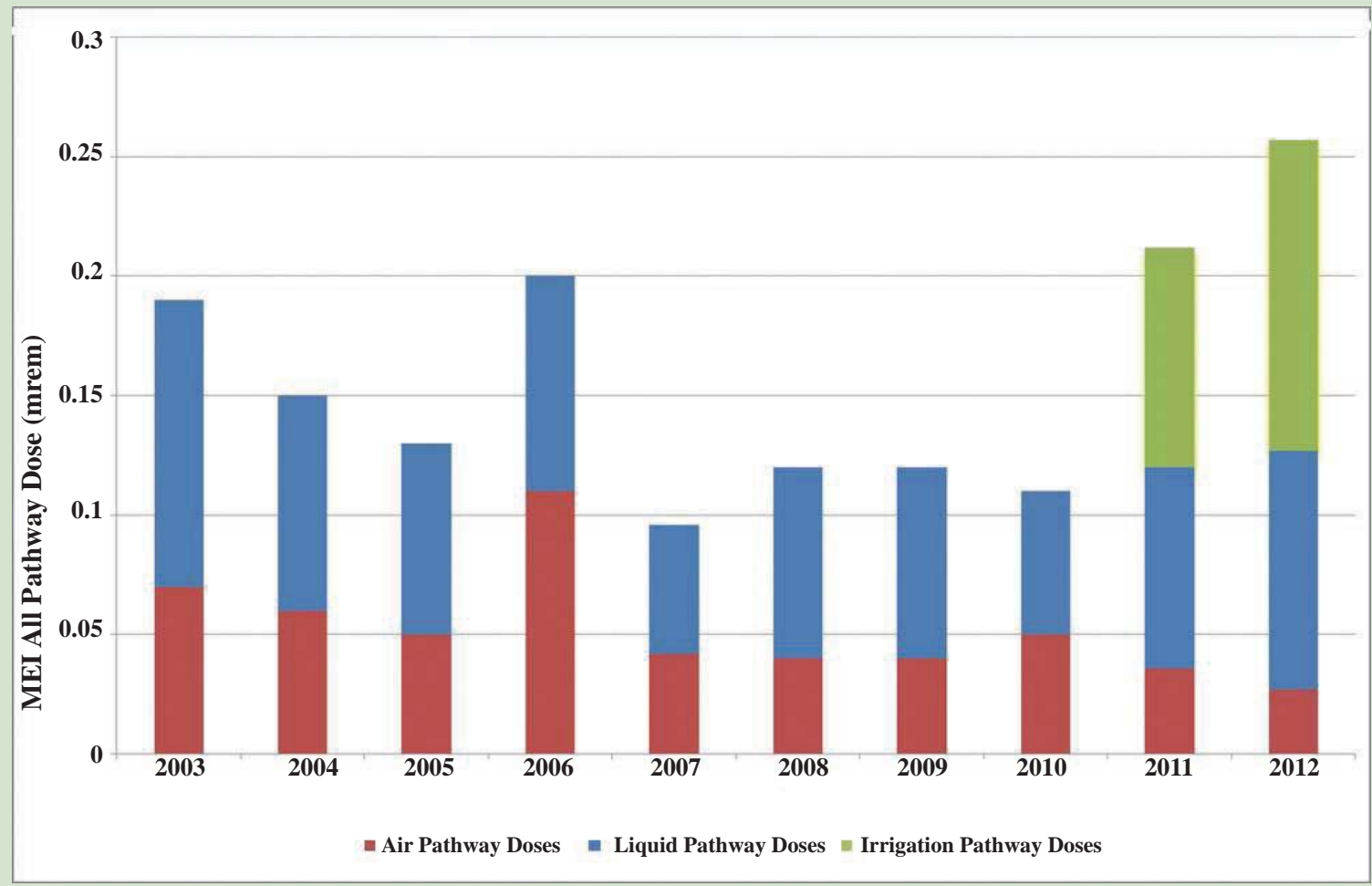

Figure 6-4 Ten-Year History of SRS Maximum Potential All-Pathway Doses

Note:

1. Beginning in 2011, the irrigation pathway dose is included in the liquid pathway dose. Previous years do not include the irrigation pathway dose.

2. Beginning in 2012, the Representative Person dose was used instead of the MEI dose.

\section{Sportsman Dose}

DOE Order 458.1 specifies radiation dose standards for individual members of the public. The dose standard of 100 $\mathrm{mrem} / \mathrm{yr}$ includes doses a person receives from routine DOE operations through all exposure pathways. Non-typical exposure pathways, not included in the standard calculations of the doses to the representative person, are considered and quantified separately. This is because they apply to low-probability scenarios such as consumption of fish caught exclusively from the mouths of SRS streams ("creek-mouth fish") or to unique scenarios such as volunteer deer hunters.

In addition to deer, hog, fish, and turkey consumption, the following exposure pathways were considered for an offsite hunter and an offsite fisherman both on Creek Plantation, a privately owned portion of the Savannah River Swamp (refer to Chapter 9, "Special Studies," for additional information):

- External exposure to contaminated soil,

- Incidental ingestion of contaminated soil, and

- Incidental inhalation of resuspended contaminated soil. 


\section{Onsite Hunter Dose}

Deer and Hog Consumption Pathway - Annual hunts, open to the general public, are conducted at SRS to control the Site's deer, feral hog, coyote, and turkey populations and to reduce animal-vehicle accidents. The estimated dose from the consumption of harvested deer, hog meat, or turkey is determined for every onsite hunter. During 2012, the maximum dose that could have been received by an actual onsite hunter was estimated at $14.5 \mathrm{mrem}(0.145 \mathrm{mSv})$, or $14.5 \%$ of DOE's 100 mrem/yr all-pathway dose standard (Table 6-5). This dose was determined for an actual hunter who in fact harvested 11 animals (ten deer and one hog) during the 2012 hunts. The hunter-dose calculation is based on the conservative assumption that this prolific hunter individually consumed the entire edible portion, almost 234 kilogram (kg) (517 pounds) of the animals that the hunter harvested from SRS in 2012.

Turkey Consumption Pathway — SRS hosts a special turkey hunt during April for hunters with mobility impairments. Twenty-eight turkeys were harvested in 2012. The dose assigned from each turkey was $1.0 \mathrm{mrem}(0.01 \mathrm{mSv})$, which is the minimum assigned dose to each successful hunter. One of the hunters harvested four turkeys in 2012 , so the maximum potential dose from this pathway was $4.0 \mathrm{mrem}(0.04 \mathrm{mSv})$.

\section{Offsite Hunter Dose}

Deer and Hog Consumption Pathway - The deer and hog consumption pathways considered were for hypothetical offsite individuals whose entire intake of meat (assumed to be $81 \mathrm{~kg}$ ) during the year was either deer or hog meat. It was assumed that these individuals harvested deer or hogs that had resided at SRS but then moved offsite. Based on these low probability assumptions and on the measured average concentration of cesium-137 in all deer $(1.27 \mathrm{pCi} / \mathrm{g})$ and hogs $(1.22 \mathrm{pCi} / \mathrm{g})$ harvested from SRS during 2012, the potential maximum doses from this pathway were estimated at $1.1 \mathrm{mrem}(0.011 \mathrm{mSv})$ for the offsite deer hunter and $0.90 \mathrm{mrem}(0.0090 \mathrm{mSv})$ for the offsite hog hunter. These dose calculations are provided in Data Table 6-30.

Table 6-5 2012 Representative Person All-Pathways and Sportsman Doses Compared to the DOE All-Pathways Dose Standard

\begin{tabular}{|c|c|c|c|}
\hline & $\begin{array}{c}\text { Committed } \\
\text { Dose (mrem) }\end{array}$ & $\begin{array}{l}\text { Applicable Standard } \\
\text { (mrem) }^{\mathrm{a}}\end{array}$ & $\begin{array}{l}\text { Percent of } \\
\text { Standard }\end{array}$ \\
\hline \multicolumn{4}{|l|}{ Representative Person Dose } \\
\hline All-Pathways (Liquid Plus Airborne Pathway) & 0.26 & 100 & 0.26 \\
\hline \multicolumn{4}{|l|}{ Sportsman Dose } \\
\hline $\begin{array}{l}\text { Onsite Hunter } \\
\text { Creek-Mouth Fisherman }^{\text {b }}\end{array}$ & $\begin{array}{l}14.5 \\
0.22\end{array}$ & $\begin{array}{l}100 \\
100\end{array}$ & $\begin{array}{l}14.5 \\
0.22\end{array}$ \\
\hline \multicolumn{4}{|l|}{ Savannah River Swamp Hunter } \\
\hline $\begin{array}{l}\text { Offsite Hog Consumption } \\
\text { Offsite Deer Consumption } \\
\text { Soil Exposure } \\
\text { Total Offsite Deer Hunter Dose }\end{array}$ & $\begin{array}{l}0.90 \\
1.10 \\
2.94 \\
4.04\end{array}$ & 100 & 4.04 \\
\hline \multicolumn{4}{|l|}{ Savannah River Swamp Fisherman } \\
\hline $\begin{array}{l}\text { Steel Creek Fish Consumption } \\
\text { Soil Exposure }^{d} \\
\text { Total Offsite Fisherman Dose }\end{array}$ & $\begin{array}{l}0.094 \\
0.072 \\
0.166\end{array}$ & 100 & 0.166 \\
\hline \multicolumn{4}{|c|}{$\begin{array}{l}\text { a All-pathway dose standard; } 100 \mathrm{mrem} / \mathrm{yr} \text { (DOE Order } 458.1) \\
\text { b In 2012, the maximum dose to a hypothetical fisherman resulted from the consumption of bass from the mouth } \\
\text { of Fourmile Branch } \\
\text { c Includes the dose from a combination of external exposure to and incidental ingestion and inhalation of the worst-case } \\
\text { d Savannah River swamp soil } \\
\text { d Includes the dose from a combination of external exposure and incidental ingestion and inhalation of } \\
\text { Savannah River swamp soil near the mouth of Steel Creek }\end{array}$} \\
\hline
\end{tabular}


A background cesium-137 concentration of $1 \mathrm{pCi} / \mathrm{g}$ is subtracted from the onsite average concentrations before calculating the doses. The background concentration is based on previous analyses of deer harvested at least 50 miles from SRS (Table 33, SRS Environmental Data for 1994) [SRS Data, 1995].

Savannah River Swamp Hunter Soil Exposure Pathway - The potential dose to a recreational hunter exposed to SRS legacy contamination in Savannah River Swamp soil on the privately owned Creek Plantation in 2012 was estimated using the RESRAD code (Yu et al., 2001 and SRS EDAM, 2010). It was assumed that this recreational sportsman hunted for 120 hours during the year (8 hours per day for 15 days) at the location of maximum radionuclide contamination.

Using the worst-case radionuclide concentrations from the most recent comprehensive survey, which was conducted in 2012, the potential dose to a hunter from a combination of (1) external exposure to the contaminated soil, (2) incidental ingestion of the soil, and (3) incidental inhalation of resuspended soil was estimated to be 2.94 mrem (0.0294 $\mathrm{mSv})$.

As shown in Table 6-5, the offsite deer consumption pathway and the Savannah River Swamp hunter soil exposure pathway were conservatively added together to obtain a total offsite hunter dose of $4.04 \mathrm{mrem}(0.0404 \mathrm{mSv})$. This potential dose is $4.04 \%$ of the DOE $100 \mathrm{mrem} / \mathrm{yr}$ all-pathway dose standard.

\section{Offsite Fisherman Dose}

Creek-Mouth Fish Consumption Pathway — For 2012, radioanalyses were conducted of three species of fish (panfish, catfish, and bass) taken from the mouths of the five SRS streams. Three composites of up to five fish of each species are analyzed from each sampling location. The resulting estimated doses are provided in Data Table 6-31. At least one of the three composites has to have a significant result for an average concentration to be reported. SRS reports the maximum dose from this combination of creek-mouth fish. As shown in Table 6-5, SRS estimated the maximum potential dose from this pathway at $0.22 \mathrm{mrem}(0.0022 \mathrm{mSv})$ from the consumption of bass collected at the mouth of Fourmile Branch. This hypothetical dose is based on the low probability scenario that, during 2012, a fisherman consumed $24 \mathrm{~kg}(53 \mathrm{lb}$ ) of bass caught exclusively from the mouth of Fourmile Branch. About $91 \%$ of this potential dose was from cesium-137. In 2012, the maximum annual fish consumption rate used in the fisherman dose calculations was increased about 26\% from $19 \mathrm{~kg}$ (pre-2012 MEI rate) to $24 \mathrm{~kg}$ (current reference person rate).

Savannah River Swamp Fisherman Soil Exposure Pathway - The potential dose to a recreational fisherman exposed to SRS legacy contamination in Savannah River Swamp soil on the privately owned Creek Plantation was calculated using the RESRAD code (Yu et al., 2001). It was assumed that this recreational sportsman fished on the South Carolina bank of the Savannah River near the mouth of Steel Creek for 250 hours during the year.

Using the radionuclide concentrations measured at this location, SRS estimated the potential dose to a fisherman from a combination of (1) external exposure to the contaminated soil, (2) incidental ingestion of the soil, and (3) incidental inhalation of resuspended soil to be $0.072 \mathrm{mrem}(0.0072 \mathrm{mSv})$.

As shown in Table 6-5, the maximum Steel Creek fish consumption dose (0.094 mrem) and the Savannah River Swamp fisherman soil exposure pathway were conservatively added together to obtain a total offsite fisherman dose of $0.166 \mathrm{mrem}(0.00166 \mathrm{mSv})$. This potential dose is $0.166 \%$ of the DOE $100 \mathrm{mrem} / \mathrm{yr}$ all-pathway dose standard.

\section{Potential Risk from Consumption of SRS Creek-Mouth Fish}

During 1991 and 1992, in response to a U.S. House of Representatives Appropriations Committee request for a plan to evaluate risk to the public from fish collected from the Savannah River, SRS developed a Fish Monitoring Plan in conjunction with EPA, the Georgia Department of Natural Resources (GDNR), and the South Carolina Department of Health and Environmental Control (SCDHEC). This plan ensures the assessment of radiological risk from the consumption of Savannah River fish, and requires a summary of the results be presented in the annual SRS environmental report. 


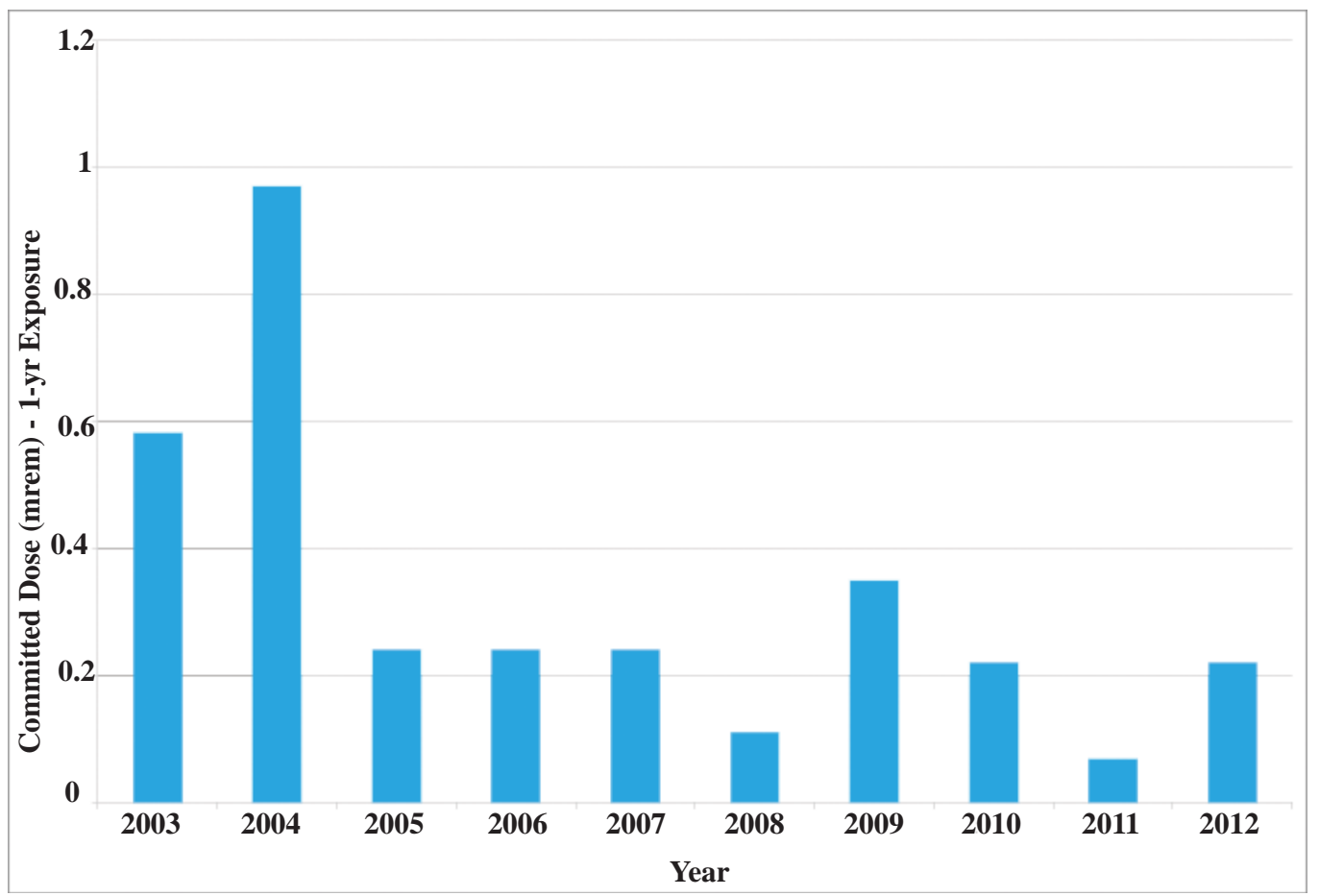

Figure 6-5 Ten-Year History of SRS Creek-Mouth Fisherman's Doses

Risk Comparisons - For 2012, the maximum potential radiation doses and lifetime risks from the consumption of SRS creek-mouth fish for 1-year, 30- year, and 50-year exposure durations are provided in Data Table 6-31. The maximum values are compared to the radiation risks associated with the DOE Order 458.1 all-pathway dose standard of $100 \mathrm{mrem} / \mathrm{yr}(1.0 \mathrm{mSv} / \mathrm{yr})$ in Table 6-6. SRS estimated the potential risks using the cancer morbidity risk coefficients from Federal Guidance Report No. 13 (EPA, 1999a). As discussed previously, in 2012, the maximum fish consumption rate was increased to $24 \mathrm{~kg}$ per year (Table 6-1). 
Table 6-6 Potential Lifetime Risks from the Consumption of Savannah River Fish Compared to Dose Standards

\begin{tabular}{|c|c|c|}
\hline & Committed Dose (mrem) & Potential Risk ${ }^{\mathrm{a}}$ \\
\hline \multicolumn{3}{|l|}{2012 Savannah River Fish } \\
\hline $\begin{array}{l}\text { 1-Year Exposure } \\
\text { 30-Year Exposure } \\
\text { 50-Year Exposure }\end{array}$ & $\begin{array}{c}0.22 \\
6.6 \\
11.0\end{array}$ & $\begin{array}{l}1.7 \mathrm{E}-07 \\
5.1 \mathrm{E}-06 \\
8.5 \mathrm{E}-06\end{array}$ \\
\hline \multicolumn{3}{|l|}{ Dose Standard } \\
\hline $\begin{array}{l}100 \text { mrem/yr All Pathway } \\
1 \text {-Year Exposure } \\
\text { 30-Year Exposure } \\
\text { 50-Year Exposure }\end{array}$ & $\begin{array}{c}100 \\
3,000 \\
5,000\end{array}$ & $\begin{array}{l}7.3 \mathrm{E}-05 \\
2.2 \mathrm{E}-03 \\
3.7 \mathrm{E}-03\end{array}$ \\
\hline \multicolumn{3}{|c|}{$\begin{array}{l}\text { all radiological risk factors are based on observed and documented health effects to actual people who have received } \\
\text { high doses (more than 10,000 mrem) of radiation, such as the Japanese atomic bomb survivors. Radiological risks at } \\
\text { low doses (less than 10,000 mrem) are theoretical and are estimated by extrapolating the observed health effects at } \\
\text { high doses to the low-dose region by using a linear, no-threshold model. However, cancer and other health effects } \\
\text { have not been observed consistently at low radiation doses because the health risks either do not exist or are so low } \\
\text { that they are undetectable by current scientific methods }\end{array}$} \\
\hline
\end{tabular}

For 2012, the maximum recreational fisherman dose was caused by the consumption of bass collected at the mouth of Fourmile Creek. Figure 6-5 shows a ten-year history of the annual potential radiation doses from consumption of Savannah River fish. Over the past ten years, no apparent trends can be identified from these data because of large variability in the cesium-137 concentrations measured in fish from the same location due to differences in the following:

- Size of the fish collected each year,

- Mobility and location within the stream mouth from which they are collected,

- Time of year they are collected,

- Amount of cesium-137 (and other radionuclides) available in the water and sediments at SRS, and

- Water quality at each SRS stream mouth, caused by annual changes in stream flow rates (turbulence) and water chemistry.

As indicated in Table 6-6, the 50-year maximum potential lifetime risk from consumption of SRS creek-mouth fish was $8.5 \mathrm{E}-06$, below the 50 -year risk (3.7E-03) associated with the $100 \mathrm{mrem} / \mathrm{yr}$ dose standard.

If a potential lifetime risk is calculated to be less than 1.0E-06 (i.e., one additional case of cancer over what would be expected in a group of 1,000,000 people), then the risk is considered minimal and the corresponding contaminant concentrations are considered negligible. If a calculated risk is more than 1.0E-04 (one additional case of cancer in a population of 10,000), then some form of corrective action or remediation usually is required. However, if a calculated risk falls between 1.0E-04 and 1.0E-06, the case with the maximum potential lifetime risks from the consumption of Savannah River fish, then the risk may be deemed acceptable if it is kept as low as reasonably achievable (ALARA), although actions to further reduce this risk can be considered. At SRS, an environmental ALARA program is in place to ensure that the potential risk from Site radioactive liquid effluents (and, therefore, from consumption of Savannah River fish) is kept ALARA (SRS EM Plan, 2013).

\section{Release of Material Containing Residual Radioactivity}

DOE Order 458.1 provides for the establishment of authorized surface contamination limits, which in turn allow unconditional release of personal and real property. This order defines personal property as "property of any kind, except for real property" and real property is defined as "land and anything permanently affixed to the land such as buildings, fences and those things attached to the buildings, such as light fixtures, plumbing and heating fixtures, or other such items, that would be personal property if not attached." Unconditional release of real property at SRS is handled on a case-by-case basis, which requires specific approval from DOE. No real property was released from SRS in 2012, so the following discussion is associated with release of personal property from SRS. DOE Order 458.1 specifies that an annual summary of cleared property must be prepared and submitted to the Field Element Manager (i.e., DOE-SR Manager). 


\section{Property Release Methodology}

Unconditional release of equipment and material at SRS is governed by procedures. Following a radiological survey, SRS specific limits are used to determine if an item can be unconditionally released. For items meeting unconditional release criteria, a form must be filled out and electronically attached to the applicable radiological survey via the Visual Survey Data System. SRS personnel compiled the electronic forms and coordinated a Site wide review to determine the amount of material and equipment released from SRS facilities in 2012.

A total of 3,728 items of personal property were unconditionally released from radiological areas by SRS radiological protection organizations in 2012. These items required no additional radiological controls post survey as they met DOE Order 458.1 release criteria (the recently implemented DOE Order 458.1 allows use of DOE Order 5400.5 derived supplemental limits for unconditional release of equipment and materials).

In 2003, DOE approved a SRS request to use supplemental limits for releasing material from the Site with no further DOE controls. These supplemental release limits, provided in Data Table 6-32, are dose-based, and are such that if any member of the public received any exposure, it would be less than $1 \mathrm{mrem} /$ year. The supplemental limits include both surface and volume concentration criteria. The surface criteria are very similar to those used in previous years. The volume criteria allow SRS the option to dispose of potentially volume-contaminated material in Three Rivers Landfill, an onsite sanitary waste facility. In 2012, SRS did not release any material from the Site using the supplemental release limits volume concentration criteria.

DOE issued a moratorium in January 2000 prohibiting the release of volume-contaminated metals, and subsequently suspended the release of metals for recycling purposes from DOE radiological areas in July 2000. No volume-contaminated metals or metals for recycling purposes were released from SRS in 2012.

These measures ensure that radiological releases of material from SRS are consistent with the requirements of DOE Order 458.1.

\section{Radiation Dose to Aquatic and Terrestrial Biota}

DOE Order 458.1 requires that SRS conduct site operations in a manner that protects the local biota from adverse effects due to radiation and radioactive material releases. Evaluations to demonstrate compliance with this requirement must be done in at least one of three approved ways. At SRS, the approved DOE Standard, DOE-STD-1153-2002, "A Graded Approach for Evaluating Radiation Doses to Aquatic and Terrestrial Biota," is the method used (DOE, 2002). The biota dose rate limits specified in this standard are:

- Aquatic Animals

- Riparian Animals

- Terrestrial Plants

- Terrestrial Animals
$1.0 \mathrm{rad} /$ day (0.01 gray/day),

$0.1 \mathrm{rad} /$ day (0.001 gray/day),

$1.0 \mathrm{rad} /$ day (0.01 gray/day), and

$0.1 \mathrm{rad} /$ day $(0.001 \mathrm{gray} /$ day $)$. 


\section{DOE Biota Concentration Guides}

SRS conducts evaluations of biota doses for aquatic and terrestrial systems using the RESRAD Biota model (version 1.5) (SRS EDAM 2010), which directly implements the DOE (2002) guidance.

For the aquatic-systems evaluation, SRS performed initial screenings in 2012 using maximum radionuclide concentration data from the 10 SRS environmental monitoring stream sampling locations from which co-located water and sediment samples are collected. An exception to this was made for sample location FM-2B (on Fourmile Branch between F Area and H Area) because of its historically high cesium and tritium concentration levels. This location was included in the initial screening even though no co-located sediment sample is collected. The combined water-plussediment biota concentration guide (BCG) sum of the fractions was used for the aquatic systems evaluation. A sum of the fractions less than 1.0 indicates the sampling site has passed its initial pathway screening. Data Table 6-33 presents the results of the 2012 biota dose assessment. All ten of the co-located water and sediment locations passed the initial screen. However, sample location FM-2B failed the initial screen (sum of the fractions was 2.27). As per DOE (2002) guidance, a level 2 screening was performed using mean concentrations instead of maximum concentrations and this location passed with a sum of the fractions of 0.477 . No further evaluations were required.

For the terrestrial-systems evaluation, initial screenings were performed using concentration data from the five onsite radiological soil sampling locations. Typically, only one soil sample per year is collected and analyzed for radioactivity from each location. For 2012, all terrestrial locations and all aquatic locations passed their initial pathway screenings (Data Table 6-33). 


\section{GROUNDWATER}

\section{Sadika O’Quinn}

Environmental Compliance \& Area Completion Projects Engineering

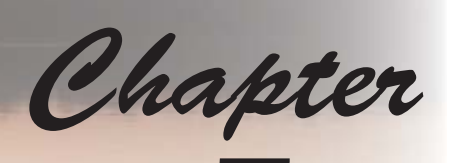

The groundwater protection program at the Savannah River Site (SRS) achieves the following objectives:

- Monitoring groundwater to identify areas of contamination;

- Remediating groundwater contamination as needed; and

- Conserving groundwater.

Previous operations contaminated the groundwater adjacent to and beneath hazardous waste management facilities and waste disposal sites on the SRS. Monitoring well data show that contaminated groundwater from the SRS has not migrated offsite. Because of these past releases, SRS operates an extensive program to monitor groundwater quality and implement technologies to remediate groundwater with unacceptable levels of contaminants. Remediation strategies include closing waste sites to reduce the potential for contaminants to migrate to groundwater and actively treating contaminated water.

Groundwater treatment operations focus on remediating volatile organic compounds (VOCs), mainly trichloroethylene (TCE) and tetrachloroethylene (PCE), and tritium resulting in the reduction of contamination present in SRS groundwater. SRS groundwater treatment operations have been successful in removing VOCs from the groundwater and reducing tritium releases into the Savannah River using surface water management and phytoremediation technologies.

This chapter describes the site-wide programs in place for investigating, monitoring, remediating, and using the groundwater.

\section{Groundwater Protection Program at SRS}

SRS has designed and implemented a groundwater protection program to meet federal and state laws and regulations, U.S. Department of Energy (DOE) orders, and SRS policies and procedures. It contains the following elements:

- Protecting SRS groundwater,

- Remediating contaminated SRS groundwater,

- Monitoring SRS groundwater, and

- Using SRS groundwater.

Monitoring provides the information needed to define strategies for using, protecting, and remediating groundwater. It is the basis for the evaluations and reporting to regulatory agencies and SRS stakeholders.

\section{Protecting SRS Groundwater}

SRS is committed to protecting the groundwater resources beneath the Site because (1) SRS must protect the public from exposure to contaminants; and (2) SRS uses groundwater for onsite purposes. A variety of activities contributes to this endeavor, including:

- Construction and waste management efforts to prevent or control sources of groundwater contamination;

- Groundwater and surface water monitoring programs to detect contaminants; and

- A successful groundwater cleanup program. 
Details concerning the integrated program for groundwater protection, management, monitoring, and restoration at SRS are provided in the Savannah River Site Groundwater Protection Program (SRNS, 2012):

http://www.srs.gov/general/programs/soil/gen/geninf.html.

\section{Monitoring SRS Groundwater}

Monitoring the groundwater around SRS facilities and known waste disposal sites provides the best means to detect and track groundwater contamination so SRS can implement appropriate remedial or corrective actions. The majority of groundwater contamination at SRS is located in its central areas and do not pose a risk of offsite contamination. To date, no offsite wells have been contaminated by groundwater from SRS. Figure 7-1 shows the groundwater plumes associated with SRS.

The SRS groundwater monitoring program includes two primary components: (1) waste site monitoring associated with remediation; and (2) groundwater surveillance monitoring. SRS evaluates groundwater monitoring data on a regulatory-approved frequency to identify whether new groundwater contamination exists or if current monitoring programs require modification in order to maintain an overall optimal monitoring program.

The SRS groundwater monitoring program also collects groundwater data to determine the effects of site operations on groundwater quality. The program:

- $\quad$ Supports SRS in complying with environmental regulations and DOE directives;

- Provides contaminant data to evaluate the current status of groundwater plumes;

- Provides water quality data necessary for evaluating the suitability of a new facility location; and

- Supports basic and applied research projects.

Monitoring efforts at SRS focus on the collection and analysis of data to characterize the groundwater flow and the presence or absence of contaminants. Characterization efforts at SRS include, but are not limited to, the following activities:

- Collecting soil and groundwater samples using cone penetrometer technology (CPT). Additional information can also be obtained from geologic soil cores or seismic profiles to better delineate subsurface structural features, as warranted;

- Installing wells to allow periodic collection of water level measurements and groundwater samples at strategic locations;

- Developing maps to help define groundwater flow in the subsurface; and

- Performing various types of tests to obtain in situ estimates of hydraulic parameters in order to estimate groundwater velocities.

Analysis of groundwater on a regional scale is conducted to provide a comprehensive understanding of SRS groundwater movement in order to better understand the migration of contaminants at the local scale (i.e., near individual waste units).

Surface water flow characteristics are also determined on the regional scale at SRS in order to assess contaminant risk to perennial streams, since they are the receptors of groundwater discharge. Because the SRS boundary does not present a groundwater boundary, regional studies are useful in understanding the movement of groundwater into SRS from surrounding areas and vice versa. 


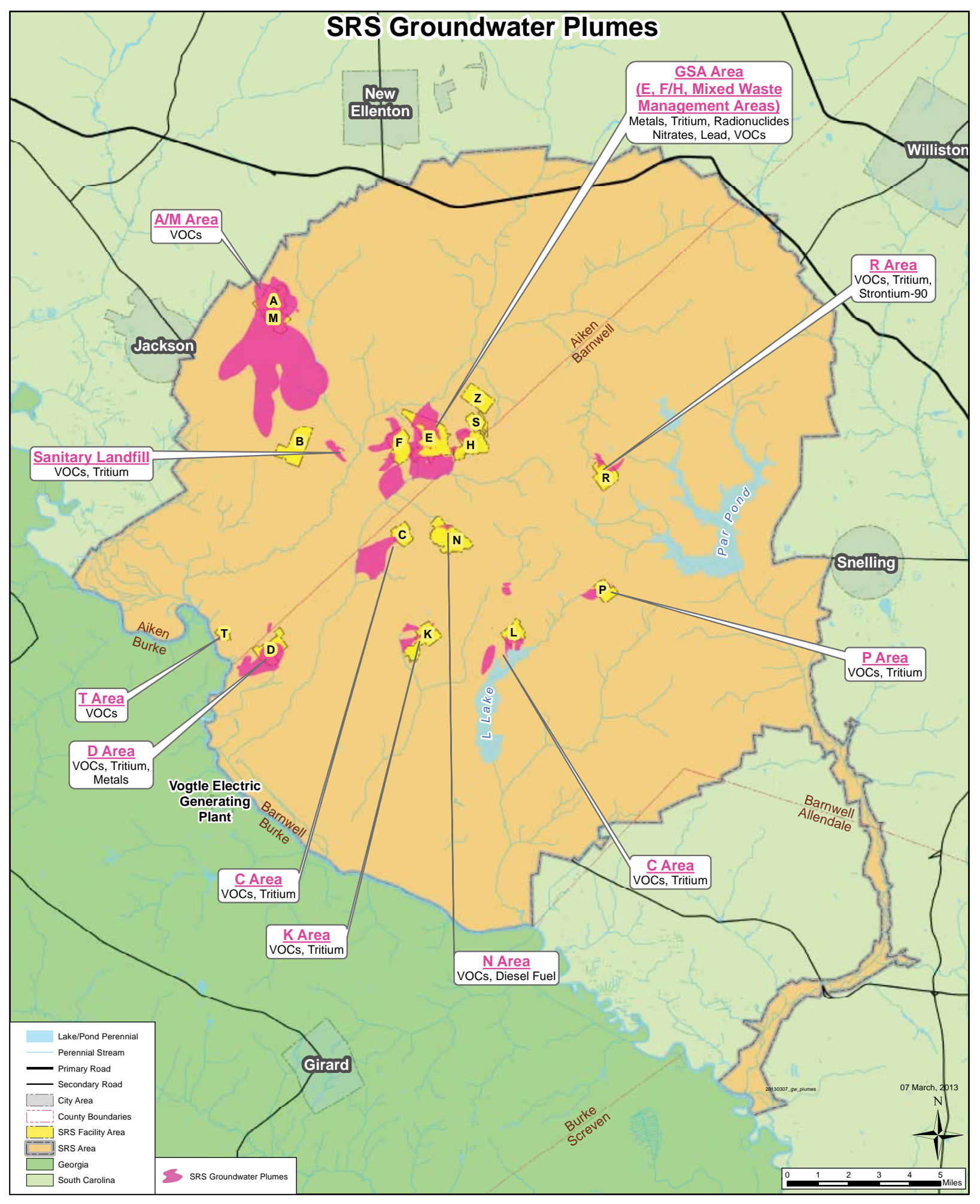

Figure 7-1 Groundwater Plumes at SRS 


\section{Sample Frequency and Collection}

SRS samples approximately 2,000 wells and numerous direct-push holes each year. Sampling frequency occurs at most wells on a semiannual basis, but also happens on monthly, quarterly, or annual basis. These sampling results provide data for reports as required by federal/state regulations, internal monitoring reports, and research projects. The results are included in Data Table 7-1 with the CD accompanying this document.

Permits or regulatory documents may require analysis of non-radioactive constituents, including metals, herbicides, pesticides, VOCs, and field parameters (such as temperature and $\mathrm{pH}$ ), and others as needed. Likewise, radioactive constituents that may be required for analysis include gross alpha and nonvolatile beta indicators, gamma emitters, iodine-129, strontium-90, radium isotopes, uranium isotopes, and other alpha and beta emitters.

SRS personnel typically collect groundwater samples via pumps or bailers dedicated to each individual well to prevent cross-contamination between the wells. SRS uses portable sampling equipment when decontamination between wells is required.

Sampling and shipping equipment and procedures are consistent with U.S. Environmental Protection Agency (EPA), South Carolina Department of Health and Environmental Control (SCDHEC), and U.S. Department of Transportation guidelines. SRS utilizes EPA-recommended preservatives and sample-handling techniques for sample storage and transportation to onsite and offsite analytical laboratories. Screening of potentially radioactive samples occurs for total activity prior to shipment to determine appropriate packaging and labeling requirements.

Deviations from scheduled sampling and analysis for 2012 (e.g., dry wells, inoperative pumps, etc.) were entered into the SRS groundwater database and issued in appropriate reports.

\section{Results Summary}

There is a significant plume beneath A/M Area. SRS uses more than 150 monitoring wells to monitor this plume. Some of these monitoring wells lie within a half-mile of the northwestern boundary of SRS. The major component of groundwater flow in the area parallels the site boundary; however, groundwater flow direction can fluctuate. Because of this pattern, SRS pays particular attention to the groundwater results from the wells located along the site boundary and between A/M Area and the nearest population center, Jackson, South Carolina (Figure 7-2). The 2012 data show no exceedances of drinking water standards in the groundwater in these wells. In the majority of wells, any contamination is less than detectable levels. All data for these site boundary wells are included in Data Table 7-1 of the "Environmental Data/Maps-2012" Appendix located on the accompanying CD.

Although most of the contaminated groundwater plumes at SRS do not approach the Site boundary, the potential to impact site streams does exist. Therefore, SRS conducts extensive monitoring adjacent to and near SRS waste sites and operating facilities, regardless of their proximity to the boundary.

Details concerning groundwater monitoring and conditions at individual sites are discussed in the Savannah River Site Groundwater Management Strategy and Implementation Plan (SRNS, 2011)

http://www.srs.gov/general/programs/soil/gen/gw_mgmt_strategy and_implementation_plan.pdf. 


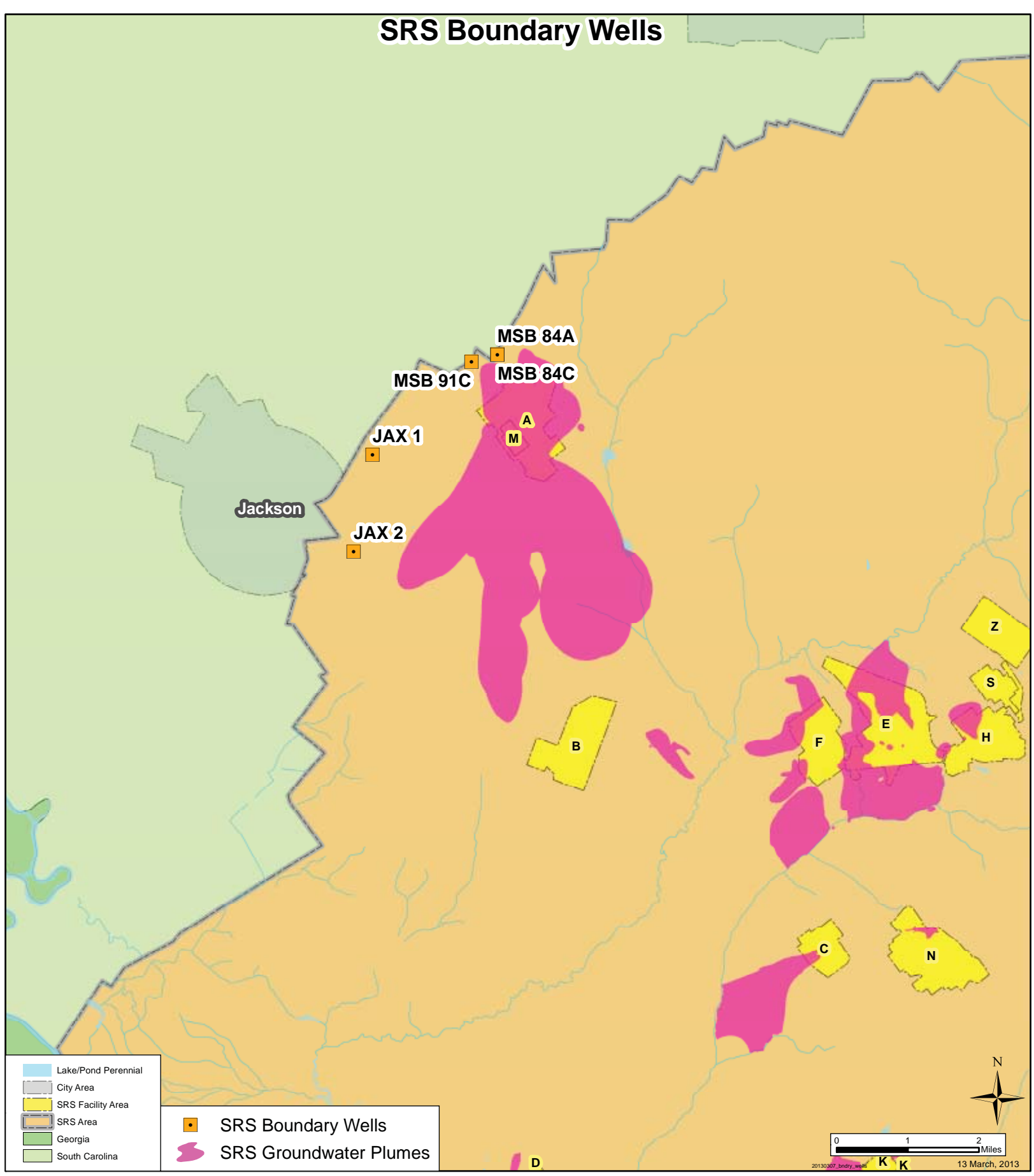

Figure 7-2 Location of Site Boundary Wells at SRS - Between A/M Areas and Jackson, South Carolina (Nearest Population Center)

Table 7-1 presents a general summary of the most contaminated groundwater conditions at SRS, based on 2012 monitoring data. The table shows the 2012 maximum concentrations for major constituents in SRS areas that have contaminated groundwater and compares these values to the appropriate drinking water standards. As shown in the table, the two major contaminants of concern in the groundwater are common degreasers (TCE and PCE) and radionuclides (tritium, gross alpha, and nonvolatile beta emitters). 
Table 7-1 Summary of Maximum Well Monitoring Results for Major Area within SRS (2012)

\begin{tabular}{|c|c|c|c|c|c|c|}
\hline Location & $\begin{array}{c}\text { Major } \\
\text { Contaminant }\end{array}$ & Units & $\begin{array}{c}2012 \\
\text { Maximum } \\
\text { Concentration } \\
\end{array}$ & Well & $\begin{array}{c}\text { Drinking Water } \\
\text { Standard }\end{array}$ & Likely Discharge Point \\
\hline \multirow[t]{3}{*}{ A/M Area } & Tetrachloroethylene & $\mu \mathrm{g} / \mathrm{L}$ & 54,800 & RWM 1 & 5 & \multirow{3}{*}{$\begin{array}{l}\text { Tims Branch/Upper Three } \\
\text { Runs in Swamp in West }\end{array}$} \\
\hline & Trichloroethylene & $\mu \mathrm{g} / \mathrm{L}$ & 59,000 & MSB101B & 5 & \\
\hline & Vinyl Chloride & $\mu \mathrm{g} / \mathrm{L}$ & 8.1 & MSB 23BR & 2 & \\
\hline \multirow[t]{3}{*}{ C Area } & Tetrachloroethylene & $\mu \mathrm{g} / \mathrm{L}$ & 9.9 & CRP 5C & 5 & \multirow{3}{*}{$\begin{array}{l}\text { Fourmile Branch and Castor } \\
\text { Creek }\end{array}$} \\
\hline & Trichloroethylene & $\mu \mathrm{g} / \mathrm{L}$ & 1,770 & CRW020D & 5 & \\
\hline & Tritium & $\mathrm{pCi} / \mathrm{mL}$ & 6,660 & CTA003D & 20 & \\
\hline \multirow[t]{3}{*}{ CMP Pits } & Tetrachloroethylene & $\mu \mathrm{g} / \mathrm{L}$ & 676 & CMP 45D & 5 & \multirow[t]{3}{*}{ Pen Branch } \\
\hline & Trichloroethylene & $\mu \mathrm{g} / \mathrm{L}$ & 566 & CMP 10C & 5 & \\
\hline & Lindane & $\mu \mathrm{g} / \mathrm{L}$ & 1.9 & CMP 10D & 0.2 & \\
\hline \multirow[t]{4}{*}{ D Area } & Tetrachloroethylene & $\mu \mathrm{g} / \mathrm{L}$ & 19.5 & DCB 45C & 5 & \multirow[t]{4}{*}{ Savannah River Swamp } \\
\hline & Trichloroethylene & $\mu \mathrm{g} / \mathrm{L}$ & 240 & DCB 62 & 5 & \\
\hline & Vinyl Chloride & $\mu \mathrm{g} / \mathrm{L}$ & 19.3 & DOB 15 & 2 & \\
\hline & Tritium & $\mathrm{pCi} / \mathrm{mL}$ & 257 & DCB 26AR & 20 & \\
\hline \multirow{2}{*}{$\begin{array}{l}\text { E Area } \\
\text { (MWMF) }\end{array}$} & Trichloroethylene & $\mu \mathrm{g} / \mathrm{L}$ & 550 & BSW 4D2 & 5 & \multirow{2}{*}{$\begin{array}{l}\text { Upper Three Runs/Crouch } \\
\text { Branch in North; Fourmile } \\
\text { Branch in South }\end{array}$} \\
\hline & Tritium & $\mathrm{pCi} / \mathrm{mL}$ & 32,300 & BSW 4D2 & 20 & \\
\hline \multirow[t]{4}{*}{ F Area } & Trichloroethylene & $\mu \mathrm{g} / \mathrm{L}$ & 26.3 & HSB $120 \mathrm{C}$ & 5 & \multirow{4}{*}{$\begin{array}{l}\text { Upper Three Runs/Crouch } \\
\text { Branch in North; Fourmile } \\
\text { Branch in South }\end{array}$} \\
\hline & Tritium & $\mathrm{pCi} / \mathrm{mL}$ & 5,160 & HSB137CR & 20 & \\
\hline & Gross Alpha & $\mu \mathrm{g} / \mathrm{L}$ & 151 & FBI 14D & 15 & \\
\hline & Nonvolatile Beta & $\mu \mathrm{g} / \mathrm{L}$ & 959 & FTF 28 & $4 \mathrm{mrem} / \mathrm{yr}^{\mathrm{a}}$ & \\
\hline \multirow{3}{*}{$\begin{array}{l}\text { F-Area } \\
\text { HWMF }\end{array}$} & Tritium & $\mathrm{pCi} / \mathrm{mL}$ & 3,130 & FSB 94C & 20 & \multirow[t]{3}{*}{ Fourmile Branch } \\
\hline & Gross Alpha & $\mu \mathrm{g} / \mathrm{L}$ & 656 & FSB 94C & 15 & \\
\hline & Nonvolatile Beta & $\mu \mathrm{g} / \mathrm{L}$ & 959 & FSB 94C & $4 \mathrm{mrem} / \mathrm{yr}^{\mathrm{a}}$ & \\
\hline \multirow[t]{4}{*}{ H Area } & Trichloroethylene & $\mu \mathrm{g} / \mathrm{L}$ & 6.5 & HGW 3D & 5 & \multirow{4}{*}{$\begin{array}{l}\text { Upper Three Runs/Crouch } \\
\text { Branch in North; Fourmile } \\
\text { Branch in South }\end{array}$} \\
\hline & Gross Alpha & $\mu \mathrm{g} / \mathrm{L}$ & 26.6 & HR3 16DU & 15 & \\
\hline & Nonvolatile Beta & $\mu \mathrm{g} / \mathrm{L}$ & 49 & HAA $15 \mathrm{~A}$ & $4 \mathrm{mrem} / \mathrm{yr}^{\mathrm{a}}$ & \\
\hline & Tritium & $\mathrm{pCi} / \mathrm{mL}$ & 88.9 & FMC-002F & 20 & \\
\hline \multirow{3}{*}{$\begin{array}{l}\text { H-Area } \\
\text { HWMF }\end{array}$} & Tritium & $\mathrm{pCi} / \mathrm{mL}$ & 5,160 & HSB137CR & 20 & \multirow[t]{3}{*}{ Fourmile Branch } \\
\hline & Gross Alpha & $\mu \mathrm{g} / \mathrm{L}$ & 60.4 & HSB102D & 15 & \\
\hline & Nonvolatile Beta & $\mu \mathrm{g} / \mathrm{L}$ & 886 & HSB105D & $4 \mathrm{mrem} / \mathrm{yr}^{\mathrm{a}}$ & \\
\hline \multirow[t]{3}{*}{ K Area } & Tetrachloroethylene & $\mu \mathrm{g} / \mathrm{L}$ & 980 & KDB 2 & 5 & \multirow[t]{3}{*}{ Indian Grave Branch } \\
\hline & Trichloroethylene & $\mu \mathrm{g} / \mathrm{L}$ & 16.1 & KRP 9 & 5 & \\
\hline & Tritium & $\mathrm{pCi} / \mathrm{mL}$ & 16.4 & KRP 9 & 20 & \\
\hline \multirow[t]{3}{*}{ L Area } & Tetrachloroethylene & $\mu \mathrm{g} / \mathrm{L}$ & 43.8 & LSW 25DL & 5 & \multirow[t]{3}{*}{ L-Lake } \\
\hline & Trichloroethylene & $\mu \mathrm{g} / \mathrm{L}$ & 11.5 & LAC 8DL & 5 & \\
\hline & Tritium & $\mathrm{pCi} / \mathrm{mL}$ & 586 & LSW 25DL & 20 & \\
\hline P Area & Tritium & $\mathrm{pCi} / \mathrm{mL}$ & 66.5 & PRB002DU & 20 & Steel Creek \\
\hline \multirow[t]{3}{*}{ R Area } & Trichloroethylene & $\mu \mathrm{g} / \mathrm{L}$ & 13 & RAG008DL & 5 & \multirow{3}{*}{$\begin{array}{l}\text { Mill Creek in Northwest; } \\
\text { Tributaries of PAR Pond }\end{array}$} \\
\hline & Tritium & $\mathrm{pCi} / \mathrm{mL}$ & 1,500 & RPS004C & 20 & \\
\hline & Strontium-90 & $\mathrm{pCi} / \mathrm{L}$ & 26.9 & RPC 11DU & 8 & \\
\hline Sanitary & 1,4-Dioxane & $\mu \mathrm{g} / \mathrm{L}$ & 330 & LFW 62C & 6.1 & Upper Three Runs \\
\hline Landfill & Trichloroethylene & $\mu \mathrm{g} / \mathrm{L}$ & 7.2 & LFW 32 & 5 & \\
\hline & Vinyl Chloride & $\mu \mathrm{g} / \mathrm{L}$ & 30 & LFW 21 & 2 & \\
\hline TNX & Trichloroethylene & $\mu \mathrm{g} / \mathrm{L}$ & 110 & TRW 3 & 5 & Savannah River Swamp \\
\hline
\end{tabular}




\section{Remediating Contaminated SRS Groundwater}

SRS's environmental remediation program has been in place for more than 20 years. The remediation and monitoring of contaminated groundwater is regulated under the Resource Conservation and Recovery Act (RCRA) and the Comprehensive Environmental Response, Compensation, and Liability Act (CERCLA) as specified in the Savannah River Site Federal Facility Agreement (FFA) (FFA, 1993).

For each groundwater project, the following actions occur: (1) developing the appropriate regulatory framework with the regulatory agencies (EPA and SCDHEC) and DOE; (2) determining the degree and extent of contamination through characterization efforts; and, if warranted, (3) deciding upon a strategy for remediating the contaminated groundwater to its original beneficial use.

SRS often applies remedial actions to the groundwater contamination source. For instance, soil vapor extraction (SVE), pulling contaminated soil vapor from the subsurface, is widely used at SRS to remove VOCs from the unsaturated (vadose) zone. Other remedial technologies deployed to the vadose zone include heating (steam or electrical resistance), chemical oxidation, and enhancing natural biodegradation through nutrient additions. Heating has also been used to volatilize tritium that has sorbed into concrete slabs.

SRS has implemented and is implementing several groundwater remedial technologies including pump and treat systems, in situ $\mathrm{pH}$ adjustments, chemical oxidation, steam injection, phytoremediation, biodegradation, natural attenuation, and subsurface barriers systems. These technologies are implemented with the intent of managing contaminant flux and reducing contaminant exposure risk to human health and ecological receptors. Thirty-nine active and passive remediation systems are currently operating. Seven groundwater treatment systems have the criteria for shutdown and are no longer in use. In 2012, 6,095 lbs. of VOCs were removed from the groundwater. Likewise, 709 curies of tritium have been removed from groundwater.

\section{Monitoring Groundwater in Georgia}

Since the early 1990s, SRS has directed considerable effort at assessing the likelihood of flow beneath the river from South Carolina to Georgia. A groundwater model developed by the U.S. Geological Survey (USGS) indicates there is no mechanism by which groundwater could flow under the Savannah River and contaminate Georgia wells (Cherry, 2006).

Despite the model results, SRS continues to monitor for tritium in groundwater wells located on the opposite side of the Savannah River in Georgia (Figure 7-3). Detections of tritium in groundwater in these offsite wells have been below $1.5 \mathrm{pCi} / \mathrm{mL}$ since 1999 (Figure 7-4). The maximum contaminant level (MCL), or drinking water standard, for tritium is $20 \mathrm{pCi} / \mathrm{mL}$. Tritium concentrations of $1 \mathrm{pCi} / \mathrm{mL}$ or less are consistent with aquifer recharge from rainfall in the Central Savannah River Area (CSRA). The overall trend of the data continues to show a gradual decline in levels of tritium in the groundwater.

SRS personnel collected groundwater samples from 39 of the 44 offsite wells during the 2012 offsite sampling event. Four wells were not sampled because they were dry (i.e., no water available); and one well could not be sampled due to mechanical failures in the well (i.e., damaged well casing). Of the 39 samples collected in 2012, 37 were nondetect for tritium. Tritium was detected in two samples, in both cases below $1 \mathrm{pCi} / \mathrm{mL}(0.721$ and $0.587 \mathrm{pCi} / \mathrm{mL})$, which is below the MCL of $20 \mathrm{pCi} / \mathrm{mL}$ for tritium. 




Figure 7-3 Location of Tritium Wells Sampled in Burke and Screven Counties, Georgia 


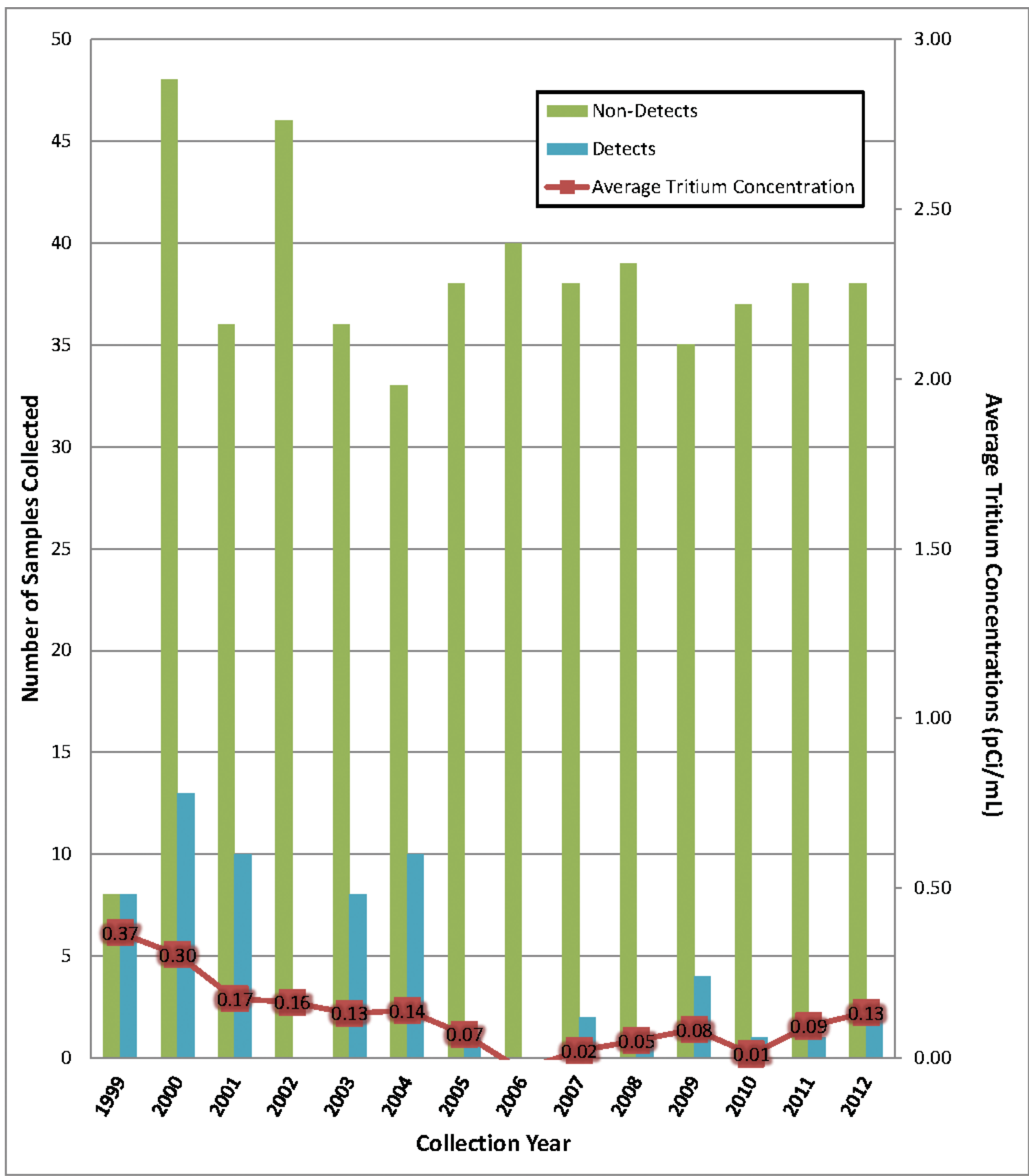

Figure 7-4 Time-Trend Data for the Georgia Tritium Wells 


\section{Using and Conserving SRS Groundwater}

SRS manages its own drinking and process water supply from groundwater located beneath the SRS. SRS domestic and process water systems are supplied from a network of approximately 40 production wells in widely scattered locations across the Site, of which eight wells supply the primary drinking water system for the SRS (Figure 14 of the "Environmental Data/Maps - 2012" Appendix found on the accompanying CD).

The production wells provide water for all the facility operations including domestic water systems. In 1983, SRS began reporting its water usage annually to the South Carolina Water Resources Commission, and later to the SCDHEC. Since that time, SRS water usage has dropped from 10.8 million gallons per day, during 1983-1986, to 3.56 million gallons per day in 2012. The consolidation of the SRS domestic water systems, completed in 1997, accounts for the majority of this decrease in water usage. Other examples of water conservation are discussed in Chapter 2, "Environmental Management System." The A-Area and D-Area domestic water systems supply treated water to the larger SRS facilities. Each system is comprised of a treatment plant, distribution piping, elevated storage tanks, and a well network. The wells range in capacity from 200 to 1,500 gallons per minute. Remote facilities, such as field laboratories, barricades, and pump houses, utilize small drinking water systems and/or bottled water. The SRS domestic water systems meet state and federal drinking water quality standards. The two large systems supply water to Site drinking fountains, lunchrooms, restrooms, and showering facilities. SCDHEC samples the systems quarterly for chemical analyses. Monitoring of the A-Area water system for bacteriological analyses occurs monthly; the D-Area water system is sampled quarterly. SCDHEC performs sanitary surveys every two years on the A-Area and D-Area systems and inspects the smaller systems every three years. All 2012 water samples were in compliance with SCDHEC and EPA water quality standards.

The process water systems are located in A, F, H, K, L, and S Areas and meet the SRS demands for boiler feedwater, equipment cooling water, facility washdown water, and makeup water for cooling towers, fire storage tanks, chilledwater-piping loops, and site test facilities. Process water wells ranging in capacity from 100 to 1,500 gallons per minute supply water to these systems. In K Area, domestic water wells supply the process water system. At some locations, the process water wells pump to ground level storage tanks, where the water is treated for corrosion control. At other locations, the wells directly pressurize the process water distribution piping system without supplemental treatment. 


\section{QUALITY ASSURANCE}

Karen Vangelas

Lori Coward

Teresa Eddy

Robert Kemmerlin

Ted Millings

Environmental Compliance \& Area Completion Projects

Sherrod Maxwell

Savannah River National Laboratory

The environmental monitoring Quality Assurance (QA) program at the Savannah River Site (SRS) ensures that the 1 environmental data collected are representative of SRS operational discharges and the surrounding environment. It is critical that analytical results are accurate so that SRS can confirm protection of human health and the environment.

The environmental monitoring QA program is a proactive process with the purpose of continuously improving the methods and techniques used to collect and analyze the environmental data that are the basis for this annual report and to prevent errors in the generation of those data. Quality Control (QC) is an integral part of the QA program using an integrated testing system to ensure the integrity of analyses performed by SRS and offsite laboratories. This chapter presents a summary of both improvements identified through the QA program, as well as the QC activities conducted to monitor the performance of the sampling activities and analytical laboratories supporting the environmental monitoring program.

The data tables identified in this chapter are located in the "SRS Environmental Data/Maps" folder on the CD accompanying this report.

\section{Background}

As required by Department of Energy (DOE) Order 414.1D, “Quality Assurance,” the environmental monitoring QA program at SRS deploys an integrated system of management activities to provide representative results to meet the requirements set forth in DOE Order 458.1, "Radiation Protection of the Public and the Environment." For consistency, SRS uses procedures to manage activities such as sample collection, laboratory analysis, data evaluation, and reporting. In addition, SRS uses procedures to manage and control the processes for evaluating environmental monitoring activities to ensure the resulting data are of an acceptable quality to support a representative evaluation of the impact of SRS operations on the health and safety of the public, workers, and the environment.

\section{Quality Assurance Program Summary}

The environmental monitoring QA program focuses on minimizing errors through ongoing assessment and control of the program components. Assessment activities evaluate the processes and actions implemented to produce the data presented in this report. Quality improvement activities associated with the environmental monitoring program that occurred in 2012 were:

- Implementation of monitoring and reporting changes,

- Evaluation of the impacts from changes in regulatory requirements to the current program, and

- Participation in a South Carolina Department of Health and Environmental Control (SCDHEC) audit to maintain certification of SRS laboratories.

Control activities are those tests and checks that ensure compliance with defined standards. The quality control activities in 2012 were continuing efforts. These included participation in the Mixed Analyte Performance Evaluation Program (MAPEP) and DOE Consolidated Audit Program (DOECAP) by supporting laboratories and collection analysis of quality control samples (i.e., duplicates, blinds) associated with field sampling activities. 


\section{Environmental Monitoring Program Assessment Activities}

SRS updated the radiological critical contaminants and critical pathway analysis to reflect current operating conditions in 2011 (Jannik et al, 2011). This information is input to the dose calculations that provide an estimate of the potential radiation exposures and subsequent potential risk to humans from SRS activities. These dose calculations document SRS's compliance with DOE Order 458.1. SRS incorporated the following recommendations from that study into the 2012 environmental monitoring program:

- Incorporate the agricultural irrigation pathway into the dose calculations. Savannah River water is used as the irrigated water. Including this pathway is consistent with the SRS Composite Analysis and presents a viable potential exposure route;

- Re-establish the SRS-specific and regional cesium-137 background concentrations used for onsite wildlife.

- Add the maximum hunter dose associated with the annual onsite turkey hunt for completeness in reporting, as presented in Chapter 5, "Environmental Surveillance," SRS began monitoring hunter dose in 2006 but the data were not incorporated in the annual report;

- Include in the reported averages all concentrations of radionuclides measured in fish only if at least one of the three composites for a species is statistically significant. This is a change from reporting all concentrations regardless of their significance and it will minimize the distortion of the importance of cesium-137 in the dose/risk calculations; and

- Reduce the number of analyses of the nonedible portions of fish to only strontium-90 in fish bones. The edible portions of fish analyses have remained unchanged. Strontium-90 more readily accumulates in bone versus fish flesh as compared to other dominant radionuclides associated with SRS operations (Friday, 1996).

In 2012, SRS completed data quality improvements to the calibration methods for both the air monitoring stations and the deer hunt monitoring equipment, as well as bringing online several new state-of-the-art sample collection devices. SRS also completed implementation of cellular wireless flow technology at liquid effluent and surveillance locations in 2012. This device allows the scientist to set limits or conditions for notification via a text or pager for flow, water level, or power outages. This resulted in a reduction in data lost due to operational problems, since users can now monitor remote sites from their desktop instead of monthly visits to each location. This allows personnel to check the equipment's operational status more frequently.

SRS now uses the SonTek RiverSurveyor ${ }^{\circledR}$ and FlowTracker-Accoustic Doppler Velocimeter ${ }^{\circledR}$ technologies, which perform field area-velocity measurements for calibration of the wireless flow monitoring devices in the site streams and validation of liquid effluent flows. These devices provide more reliable average stream velocity measurements in either two or three dimensions, have built-in calibrations that are performed during each field use, and are simple to operate. Through implementation of these devices, the data quality improvements include: (1) warnings to the scientist, (2) results with an accuracy of $1 \%$ of measured velocity and (3) as a result, less operator error. Prior to 2012, SRS used an electromagnetic velocity meter for field area-velocity measurements. This device measures velocity in one direction, has no easy way to perform calibration without shipping to the vendor, and displays velocity as a continuous digital display requiring human judgment

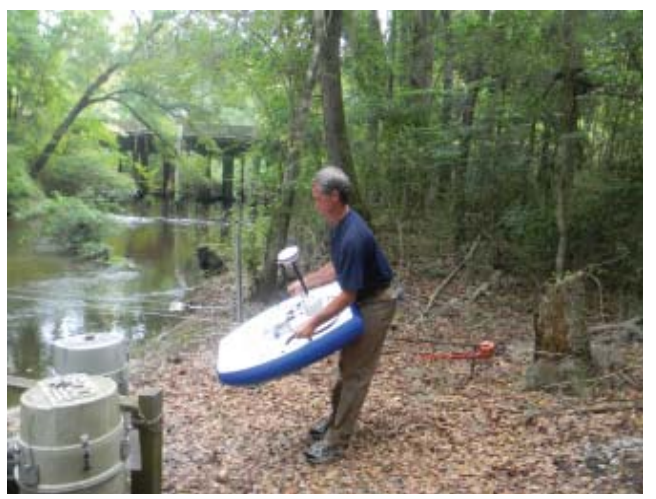

Figure 8-1 Field Technician Preparing to Deploy River-Surveyor ${ }^{\circledR}$ in a SRS Waterway for determination of the average velocity. In addition, the use of the RiverSurveyor ${ }^{\circledR}$ has improved safety for the field technicians by eliminating the need to enter waters that may be inhabited by alligators (Eddy et al., 2012).

Another aspect of the QA program is to employ laboratories certified by the SCDHEC Office of Laboratory Certification for those parameters monitored through the SRS environmental monitoring program. Offsite subcontract laboratories are certified by SCDHEC for a large variety of environmental analyses. SCDHEC also certifies onsite SRS laboratories that support the environmental monitoring program for the following: field $\mathrm{pH}$, temperature, total residual chlorine, biological oxygen demand, fecal coliform, low-level mercury, total suspended solids, and metals. In 
2012, SCDHEC performed an onsite recertification evaluation of one of the three SRS onsite laboratories supporting the environmental monitoring program, renewing the certification. SRS renews these certifications every three years, with the current certificates expiring between March 2014 and June 2015 for the three-onsite laboratories supporting environmental monitoring activities.

In May 2012, the Environmental Protection Agency (EPA) issued a final rule to approve new and revised analytical methods for the analysis of wastewater, referred to as the "Methods Update Rule II." This rule affects laboratories certified to perform wastewater [National Pollutant Discharge Elimination System (NPDES)] analyses under the Clean Water Act. SRS reports NPDES data as part of the effluent monitoring program described in Chapter 4, "Effluent Monitoring." During 2012, SRS reviewed this new rule and identified several analytes within the NPDES program that will require changes associated with their analytical methods. SRS will begin implementation activities in 2013, as prescribed by the schedule issued by SCDHEC. Compliance with the Methods Update Rule II will enable the laboratories to maintain their certification to perform NPDES analyses.

\section{Environmental Monitoring Program Quality Control Activities}

\section{Quality Control Sampling}

Sampling personnel collect several types of QC samples periodically throughout the year, including field blinds and duplicates, to evaluate the source of any measurement error. SRS personnel routinely conduct blind sample analyses for field measurements of $\mathrm{pH}$ to assess the quality and reliability of field data measurements. All of the 2012 blind sample analyses were within the acceptable limit of less than a $0.4 \mathrm{pH}$ unit difference between the original and blind samples. Data Table 8-1 contains the results of the blind pH samples.

The results of SRS onsite and subcontract laboratory blind and duplicate sample analyses indicate that although there were some differences, no problems consistently occurred within the laboratories during 2012. Six out of 86 blind samples and 3 out of 84 duplicate samples were outside the acceptable limit of a $20 \%$ difference between the original sample and the QC sample (blind or duplicate). Sampling personnel could not collect blind samples at three locations and duplicate samples at four locations due to no water flow during the scheduled sampling event. Data Tables 8-2 and 8-3 contain the field blind and duplicate sample program results.

SRS's water quality program requires checks of $10 \%$ of the samples to verify analytical results. SRS and a subcontract laboratory analyzed duplicate samples from SRS streams and the Savannah River in 2012. Out of 576 duplicate samples, 32 were outside the acceptable limit of a $20 \%$ difference between the original samples and the duplicate. Sampling personnel could not collect field duplicate samples at one location due to no water flow during the scheduled sampling event. Though results for the field duplicate sampling program indicate there were some differences between duplicates, no problems consistently occurred within the laboratories. Data Table 8-4 contains detailed SRS stream and Savannah River field duplicate sample results.

\section{Laboratory Proficiency Testing}

SRS laboratories performing NPDES analyses maintained state certification for all analyses after achieving acceptable results in SCDHEC required proficiency testing studies. The proficiency testing is required per State Regulation 61-81 ("State Environmental Laboratory Certification Program”). All laboratories used proficiency testing providers accredited by the American Association of Laboratory Accreditation. During 2012, the three subcontract laboratories that support the SRS environmental monitoring program participated in various water pollution performance evaluation studies. The subcontract laboratories reported acceptable proficiency testing results for an average $98.5 \%$ of the parameters tested; therefore, maintaining SCDHEC certification for all analyses.

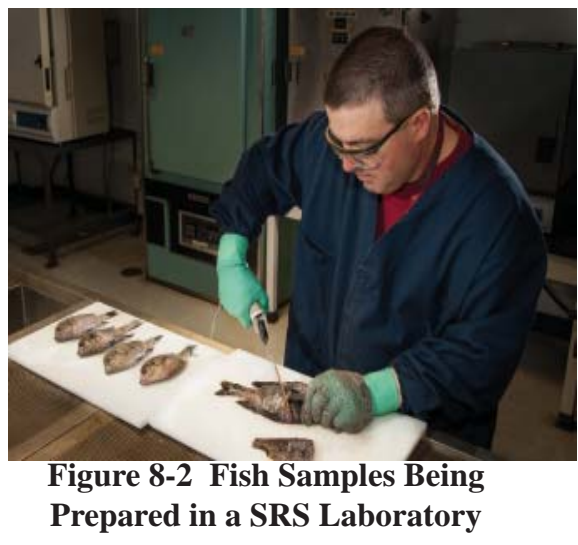


SRS onsite and subcontract laboratories continued to participate in MAPEP, a laboratory comparison program that tracks performance accuracy and tests the quality of environmental data reported to DOE. MAPEP samples include water, soil, air filter, and vegetation matrices, all with environmentally important stable inorganic, organic, and radioactive constituents. MAPEP offered two separate studies in 2012. SRS onsite laboratories participated in both studies, with satisfactory performance test analyses results for each. MAPEP results for subcontract laboratories used by SRS in 2012 were also satisfactory, with an average percent of passing parameters of $99.7 \%$ for water matrix, 99.8\% for soil matrix, and $95.6 \%$ for vegetation matrix. The laboratories will evaluate the cause of the failed analyses and will be required to develop corrective actions to prevent a recurrence.

To help laboratory participants identify, investigate, and resolve potential quality concerns, MAPEP issues a letter of concern to a participating laboratory upon identification of potential analytical data quality problems in the MAPEP results. MAPEP began issuing letters of concern in 1996 with the intention of being informative and not punitive. MAPEP sends a copy of each letter to DOE/contractor oversight points of contact. Overall, the laboratories performed very well on MAPEP studies; however, two of the subcontract laboratories received Priority I notifications due to missing the same analyte in the same matrix in two consecutive studies. In both cases, these failed performance evaluation samples did not affect SRS data because SRS did not send samples to these laboratories during 2012 for these analyte/matrix combinations.

The DOECAP implements a comprehensive audit program for conducting annual audits of commercial laboratories (subcontract laboratories) with the main purpose of providing trained auditors to support consolidated audits, thereby eliminating audit redundancy from the DOE program field sites. The DOECAP performs an audit of each subcontract laboratory annually to ensure the laboratories demonstrate technical capability and proficiency while following the required DOE QA programs. The evaluation includes an examination of laboratory performance with regard to sample receipt, instrument calibration, analytical procedures, data verification, data reports, records management, nonconformance and corrective actions, and preventive maintenance. A Priority I finding documents a deficiency that is of sufficient magnitude to render the audited facility unacceptable to provide the affected service to DOE. A Priority II finding documents a deficiency that is not of sufficient magnitude to render the audited facility unacceptable to provide service to DOE.

The subcontract laboratories continued to participate in the DOECAP comprehensive audit program that focuses on commercial laboratories. In 2012, DOECAP personnel conducted audits at the subcontract laboratories, resulting in no Priority I findings and 36 Priority II findings, which were evenly distributed among the laboratories audited. DOECAP provided an audit report of the 2012 findings to each laboratory. Each affected laboratory then submitted corrective action responses to DOECAP. Subsequently, DOECAP reviewed the responses to confirm that the corrective action will remediate the quality issue. The findings typically are resolved during the next annual laboratory audit (scheduled for 2013). Additionally during the 2012 audit, the laboratories submitted corrective action responses that addressed each finding identified during 2011, thereby closing 18 of the 19 Priority II findings. There were no Priority I findings in 2011. The laboratories are planning to close out the one remaining 2011 Priority II finding during the next scheduled audit in 2013. 


\title{
SPECIAL STUDIES
}

\section{Teresa Eddy \\ Susan Blas \\ Environmental Compliance \& Area Completion Projects}

\section{Brian Looney, Dennis Jackson,}

Michael Paller, Timothy Jannik

Savannah River National Laboratory

\section{William Wabbersen \\ National Nuclear Security Administration Operations}

\begin{abstract}
$T^{n}$ addition to the routine compliance activities reported in the previous chapters, the Savannah River Site (SRS),
1 performs special studies to evaluate the use of innovative technologies in environmental cleanup strategies, to determine environmental impacts of contaminants released from SRS operations to locations not sampled as part of compliance sampling, and establish a baseline prior to start-up of any new activity or facility so that impacts of the new operations can be assessed over time.
\end{abstract}

In order to understand the impacts of past, current, and future operations on human health and the environment, SRS conducted or participated in the following special studies during 2012:

- National Atmospheric Deposition Program,

- Comprehensive survey of Savannah River Creek Plantation Swamp,

- Public harvesting and sampling of American Alligators,

- Trophic (food chain) modeling to assess potential ecological threats of ash deposits in the Wetlands Area at Dunbarton Bay, and

- Special study of mercury and tin in the Tims Branch ecosystem.

These activities support informed decision-making regarding environmental monitoring, protection of the public, and validating or assessing environmental clean-up programs at SRS.

\section{National Atmospheric Deposition Program}

\section{Description of Surveillance Program}

Savannah River National Laboratory (SRNL) sponsors a monitoring and collection station that is part of the National Atmospheric Deposition Program (NADP). The NADP provides fundamental measurements that support informed decisions on environmental issues such as atmospheric mercury and acid rain. NADP data are relevant to scientists, educators, policymakers, and the public. Additional information on this network is accessible via the following link: http://nadp.sws.uiuc.edu/mdn/.

Since 2001, SRS has operated a monitoring station within the program's Mercury Deposition Network (MDN). This network provides data on the geographic distributions and trends of mercury in precipitation. It is the only network providing a long-term record of mercury concentrations in North American precipitation. All monitoring sites follow standard procedures and have uniform precipitation collectors and gauges. Following equipment upgrades in 2010 and 2011, the mercury deposition station at SRS (SC03) is fully modernized and satisfies network collection requirements.

In 2012, an additional precipitation collector was added to the station as part of the National Trends Network (NTN). This network is also part of the NADP with the focus of monitoring major anions and cations that are present in precipitation. Weekly precipitation samples from this collector are sent to a central laboratory for analysis of free acidity, specific conductance, and calcium, magnesium, sodium, potassium, sulfate, nitrate, chloride, bromide, and ammonium ions. 


\section{Results Summary}

During calendar year 2011 (the last year for which data is available), the average (volume weighted) concentration of total mercury in precipitation was $10.6 \mathrm{ng} / \mathrm{L}$ and the wet deposition rate was $9.1 \mu \mathrm{g} / \mathrm{m}^{2}$ (Figure 9-1).

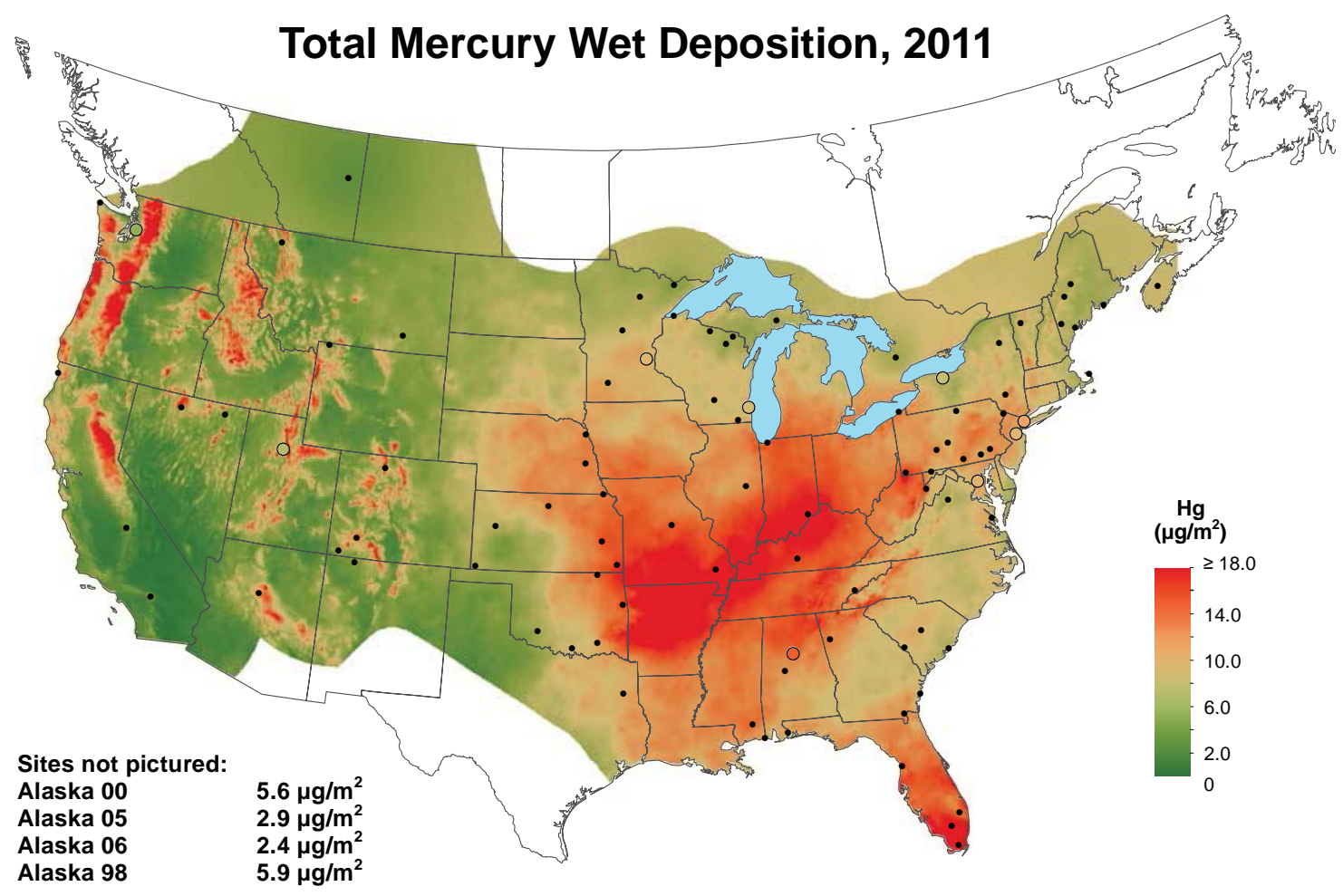

National Atmospheric Deposition Program/Mercury Deposition Network http://nadp.isws.illinois.edu

Figure 9-1 2011 Total Mercury in Rainfall Results from the National Atmospheric Deposition Program (NADP)

Data from 2012 will not be available until the fall of 2013.

SRS initiated sampling in support of the NTN in late December of 2011. The complete dataset for 2012 will not be available until the fall of 2013. These results will be reported in the 2013 annual report.

\section{Comprehensive Survey of Savannah River Creek Plantation Swamp}

Creek Plantation, privately owned land along the Savannah River, borders the southern boundary of SRS. In the 1960s, SRS operations impacted an area of the Savannah River swamp on Creek Plantation, specifically the area between Steel Creek Landing and Little Hell Landing (Figure 9-2), when water from Steel Creek flowed into the swamp during high river levels, resulting in the deposition of radioactive material. SRS studies estimated that a total of approximately 25 Curies (Ci) of cesium-137, 1 Ci of cobalt-60, and trace amounts of strontium-90 were deposited in the swamp. 


\section{Approach}

SRS performs annual surveys of Creek Plantation swamp in order to determine the amount and distribution of radioactivity that was deposited there during the 1960s. Radiological surveys of Creek Plantation swamp measure radioactivity levels along a series of 10 sampling trails, ranging from 240 to 3,200 feet in length (Figure 9-2). Fifty-four monitoring locations are designated on the trails to allow for continued monitoring at a consistent set of locations. Comprehensive and cursory surveys of the swamp have been conducted periodically since 1974. Cursory surveys provide assurance that conditions observed during the more detailed comprehensive surveys have not changed significantly. A comprehensive survey (requiring additional media sampling and analyses) is performed every five years and was conducted during 2012.

The 2012 comprehensive survey required sampling of soil and vegetation, as well as field placement of thermoluminescent dosimeters (TLDs) for measuring external gamma exposure. TLDs are placed into the field at designated locations. The crystals in the dosimeters absorb the gamma exposure over time and are analyzed for the gamma exposure rates in air.

The soil, vegetation, and TLD results were compared to gamma overflight measurement results also obtained during 2012. Gamma overflight measurements are obtained using gamma spectroscopy instrumentation from a helicopter flying over the Creek Plantation at slow speeds. The gamma spectroscopy instrumentation obtains an average of spectral counts for a footprint over time. These measurements provide the levels of gamma-emitting radionuclides such as cesium-137.

\section{Results Summary}

The 2012 survey confirmed previous observations that cesium-137 is the primary man-made radionuclide detected in Creek Plantation. Cesium-137 was detected in nearly all of soil samples and in about half of the vegetation samples. No cobalt-60 was detected in any of these samples. The highest concentrations occurred on Trails 1 and 5 (Figure 9-2) and concentrations decreased with depth. These levels are consistent with the aerial survey measurements showing the highest gamma footprint for cesium-137 around Trail 1. Historical trends of the maximum soil concentrations indicate a decreasing trend with levels lower than would be expected from radioactive decay, which indicate the dose hazard has decreased more quickly in the environment than anticipated.

SRS placed TLDs at 52 monitoring sites in the swamp to determine ambient gamma exposure rates, and retrieved all but two of them, which were unrecoverable. The gamma exposure rates were consistent with the ranges observed historically (see Data Table 9-3 on the CD accompanying this report for additional details). The highest exposure rates were measured on Trails 1 and 5, consistent with cesium-137 results in soil and gamma footprints from aerial survey measurements (Figure 9-2 and Table 9-1). More information on exposure and dose results from the Creek Plantation datasets can be found in Chapter 6, "Radiological Dose Assessments."

Table 9-1 2012 TLD Survey Results for Creek Plantation, milliRoentgen

\begin{tabular}{|c|c|c|}
\hline Trail & Minimum & Maximum \\
\hline 1 & 0.17 & 0.51 \\
\hline 2 & 0.18 & 0.32 \\
\hline 3 & 0.22 & 0.24 \\
\hline 4 & 0.23 & 0.29 \\
\hline 5 & 0.28 & 0.42 \\
\hline 6 & 0.24 & 0.39 \\
\hline 7 & 0.30 & 0.36 \\
\hline 8 & 0.31 & 0.39 \\
\hline 9 & 0.26 & 0.37 \\
\hline 10 & 0.22 & 0.30 \\
\hline
\end{tabular}


Figure 9-2 depicts the 2012 sampling results for cesium-137 in surface soil ( 0 to 3 inches) overlaid with aerial footprints from the 2011 aerial gamma measurements. The color schemes for gamma over flight results indicate lowest to highest concentrations-green, yellow, orange, and red. Higher levels highlighted in red are below the limit for SRS Soil Contamination Areas of $150 \mathrm{pCi} / \mathrm{g}$ for cesium-137. Dose impacts are described in Chapter 6, "Radiological Dose Assessments" under the soil exposure to the swamp hunter. Gamma over flight results color schemes correlate well with the soil results. Table 9-2 summarizes the cesium-137 results for soil and vegetation for each trail. Additional details can be found in Data Table 9-1 for soil and Data Table 9-2 for vegetation.

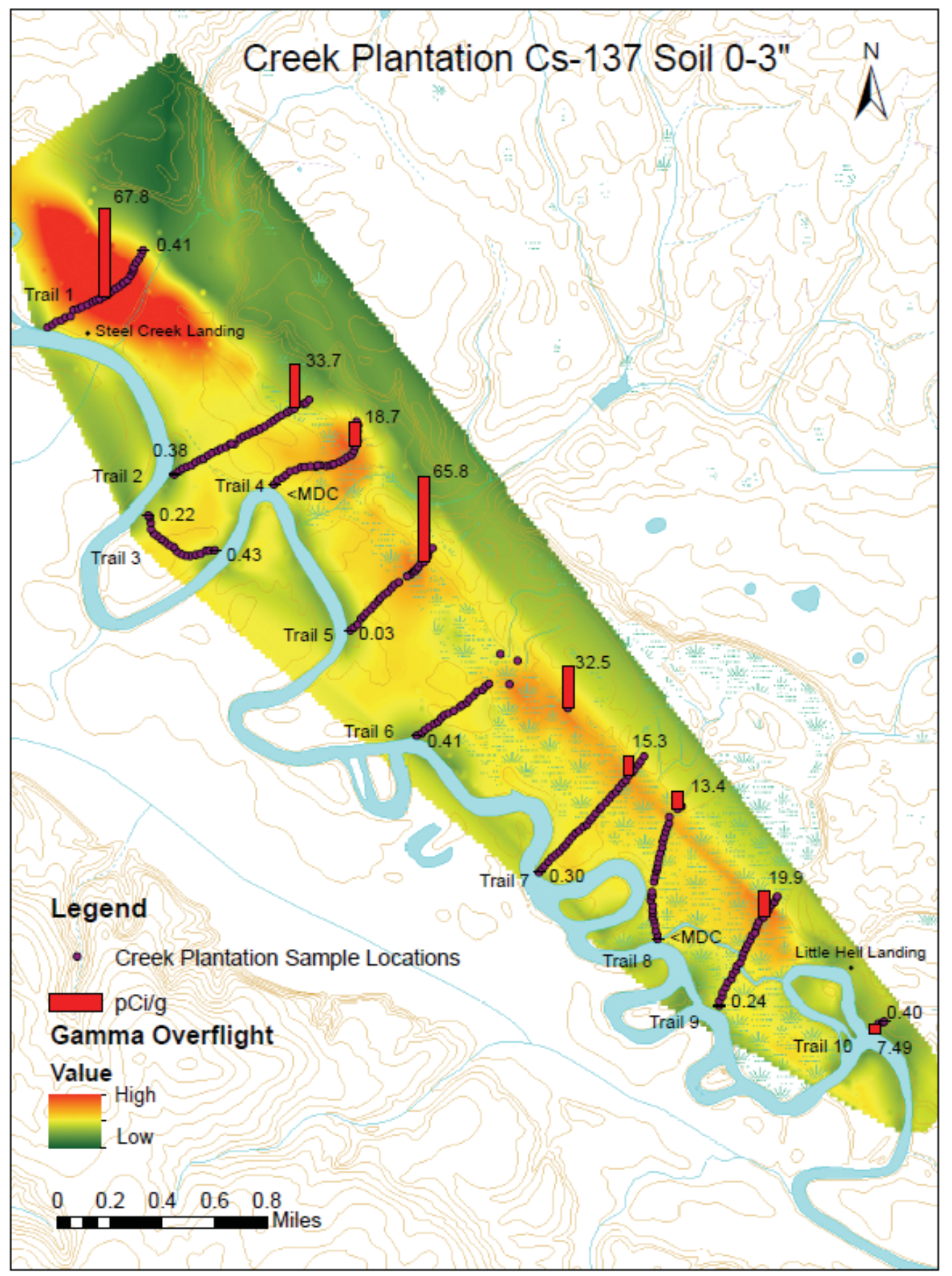

Figure 9-2 Results for Cesium-137 in Surface Soil at Creek Plantation and 2011 Aerial Gamma Survey Measurements 
Table 9-2 2012 Results for Cesium-137 in Soil and Vegetation at Creek Plantation, pCi/g

\begin{tabular}{|c|c|c|}
\hline \multicolumn{3}{|c|}{ Vegetation } \\
\hline Trail & Minimum & Maximum \\
\hline $1 *$ & $<\mathrm{MDC}$ & 2.06 \\
\hline 2 & $<\mathrm{MDC}$ & 0.23 \\
\hline 3 & $<\mathrm{MDC}$ & $<\mathrm{MDC}$ \\
\hline 4 & $<\mathrm{MDC}$ & 1.76 \\
\hline 5 & $<\mathrm{MDC}$ & 5.41 \\
\hline 6 & $<\mathrm{MDC}$ & 3.80 \\
\hline 7 & $<\mathrm{MDC}$ & 1.70 \\
\hline 8 & $<\mathrm{MDC}$ & 0.22 \\
\hline 9 & $<\mathrm{MDC}$ & 6.53 \\
\hline 10 & $<\mathrm{MDC}$ & 0.83 \\
\hline \multicolumn{3}{|c|}{ Soil } \\
\hline Trail & Minimum & Maximum \\
\hline 1 & 0.41 & 67.8 \\
\hline 2 & 0.38 & 33.7 \\
\hline 3 & 0.22 & 0.43 \\
\hline 4 & $<\mathrm{MDC}$ & 18.7 \\
\hline 5 & 0.03 & 65.8 \\
\hline 6 & 0.41 & 32.5 \\
\hline 7 & 0.3 & 15.3 \\
\hline 8 & $<\mathrm{MDC}$ & 13.4 \\
\hline 9 & 0.24 & 19.9 \\
\hline 10 & 0.4 & 7.49 \\
\hline $\begin{array}{l}\text { Trail 1-2,150 ft and 2,6 } \\
\text { because of timber harve }\end{array}$ & cted due to & \\
\hline
\end{tabular}

Due to timber harvesting activities near Trail 1, vegetation samples were not collected at certain higher gamma activity locations. However, woodchips from timber harvesting activities were collected and results are summarized in Table 9-3.

Table 9-3 Cesium-137 and Strontium-89, 90 Results for Timber Wood Chips near Creek Plantation Trail 1

\begin{tabular}{|c|c|c|}
\hline Location & Cs-137 Concentration & Sr-89,90 Concentration \\
\hline Trail 1-2600 ft & 0.19 & 0.50 \\
\hline Trail 1-2150 ft & 0.80 & 0.26 \\
\hline Steel Creek Boat Landing near Trail 1 & $<\mathrm{MDC}$ & 0.27 \\
\hline Steel Creek Boat Landing near Trail 1 & $<\mathrm{MDC}$ & 0.22 \\
\hline
\end{tabular}

The health impacts of these results are described in more detail in the Sportsman Dose section of Chapter 6, "Radiological Dose Assessments." 


\section{American Alligator Public Harvest Program in Georgia and South Carolina}

The American alligator (Alligator mississippiensis) lives in the southeastern region of the United States. The historical range included the coastal plain portion of the Savannah River watershed, including SRS. Georgia and South Carolina have a flourishing population of alligators managed through a regulated hunting season. Georgia (GA DNR, 2013) and South Carolina (SC DNR, 2013) control public hunting and monitor harvests using permits (tags) issued by each state's Department of Natural Resources (DNR).

On SRS, alligators are abundant in the Savannah River, its swamp and tributaries, L-Lake, Par Pond, and other reservoirs on the site (Figure 9-3) (SREL, 2013). Researchers at the Savannah River Ecology Laboratory (SREL) have extensively studied these alligators (Brisbin et al. 1989, 1992, 1997; Jagoe et al. 1998). Long-term studies by SREL have been the foundation for the analysis and interpretation of the fate and effects of mercury and radioactive contaminants in these animals. However, some individual alligators have accumulated muscle tissue levels of mercury and cesium-137 that would make human consumption of their meat an issue of potential concern. Even though the SRS is closed to public access and alligator hunting is prohibited, larger alligators can leave the Site's boundaries and move onto public lands where they could be harvested (Brisbin et al. 1992; 1997).

SRS is interested in understanding harvest rates of alligators that may have been associated with the Site to ensure that the public is not exposed to potentially harmful levels of Site-related contamination in alligator meat harvested in the vicinity of the Site. The Agency for Toxic Substances and Disease Registry (ATSDR, 2012) recently recommended that SRS remain informed of the types of biota consumed by humans and provide adequate monitoring for species that may be impacted by Site-related contamination.

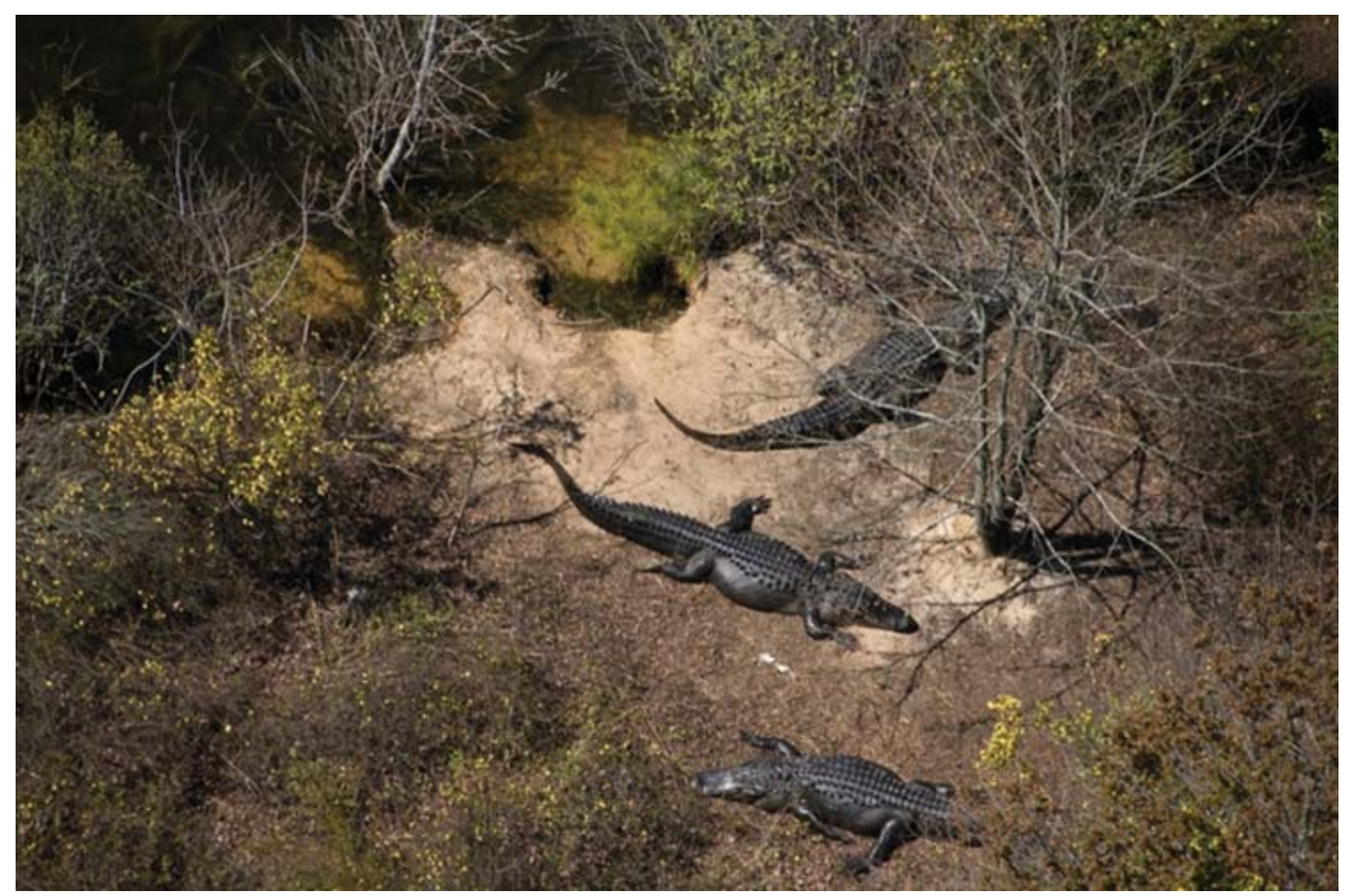

Figure 9-3 Mature American Alligators Basking in the Sun on the Banks of L-Lake Public alligator hunting is prohibited on SRS 


\section{Approach}

As part of the effort to answer questions about the potential for members of the public to harvest and consume contaminated alligators, SRS personnel researched harvest statistics for South Carolina and Georgia. Of particular interest are alligators harvested from Aiken, Allendale, and Barnwell counties since they border SRS. The annual harvest data (2008 to 2012) from these counties is presented in Figure 9-4. The data from South Carolina indicates an average of seven alligators were harvested from Aiken, Barnwell, and Allendale Counties between 2008 and 2012. SRS is working with Georgia DNR to obtain unpublished county specific harvest data for those Georgia counties that border SRS.

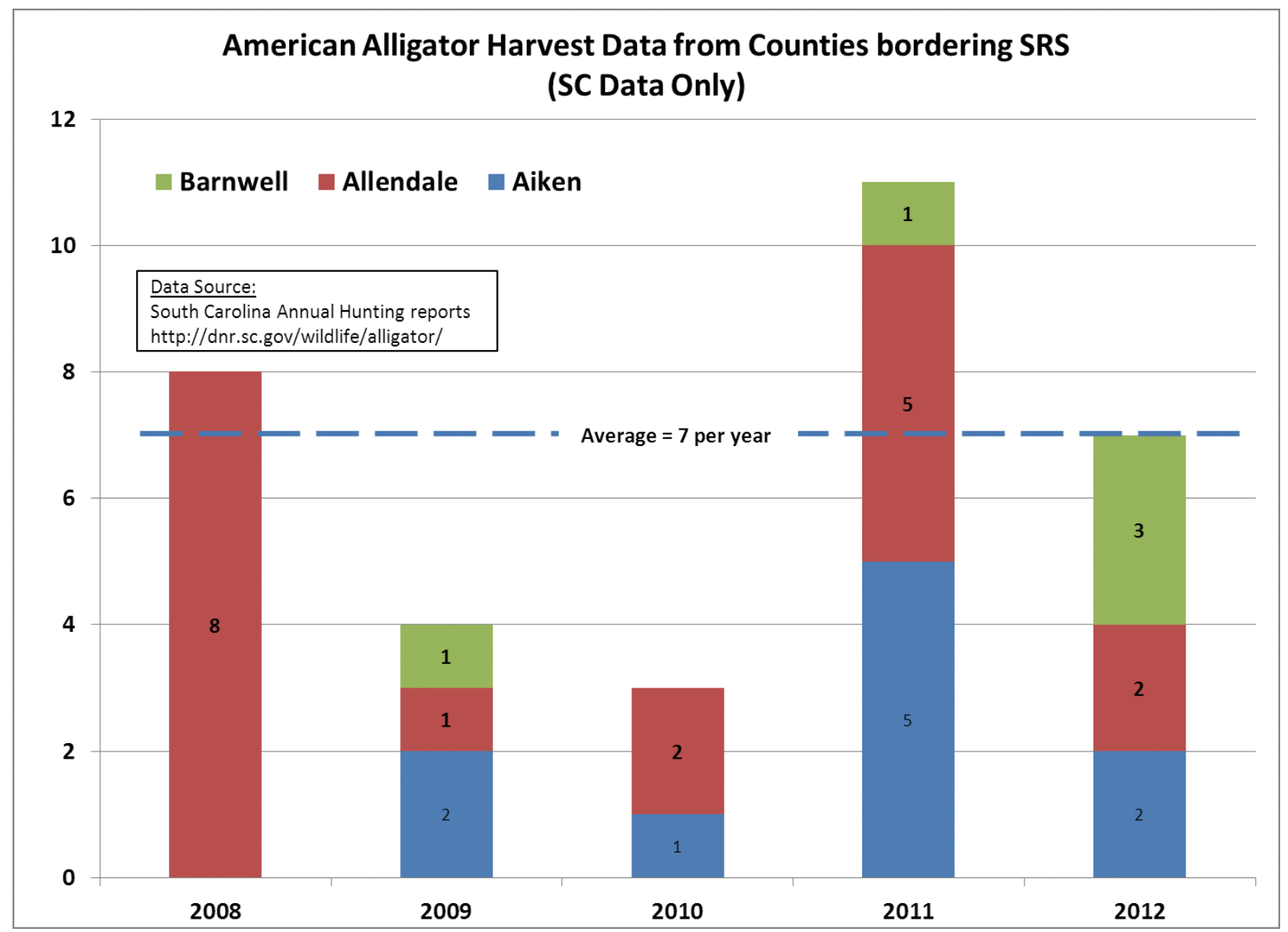

Figure 9-4 American Alligator Harvest data for counties that border SRS (Data compiled from South Carolina Department of Natural Resources reports)

In the summer of 2012, a local hunter donated a portion of meat from two alligators. One alligator was harvested in September of 2010 (GA-0003766) and the second was harvested in September of 2011 (SC-12113). Both animals were harvested from the Savannah River near Little Hell Landing. Following initial harvest, the hunter froze and stored the tail meat. In the summer of 2012, the hunter delivered the frozen meat to SRS. The laboratory thawed and analyzed the meat for total mercury and gamma-emitting radionuclides. The analysis targeted chemicals known to either bioaccumulate, mercury, or long-lived man-made gamma-emitting radionuclides, cesium-137. The analysis identified mercury and cesium-137 in both alligators as well as the naturally occurring radionuclides potassium-40, uranium-234, and uranium-238 (Table 9-4). 


\section{Results Summary}

Radiological and nonradiological results are summarized in Table 9-4 below. Since only one sample was available from the 2010 and 2011 harvests, conclusive statements regarding concentration and activities are not possible. In order to determine potential risk associated with consumption of alligators harvested from the Savannah River, SRS contrasted the results from each year with results from edible fish for that year. SRS developed the ranges using offsite freshwater fish data reported in Chapter 5, "Environmental Surveillance," of the 2010 and 2011 SRS Environmental Reports (SRNS 2010, 2011). Figure 9-5 illustrates the comparison between mercury and radionuclide levels detected in fish and alligators.

Based upon the limited information (single samples from 2010 and 2011 harvests), the level of mercury and cesium-137 observed in alligator are consistent with observations from fish collected in the Savannah River (Figure 9-5). For 2010 and 2011, the observed cesium-137 concentration in alligator aligned with the cesium-137 fish values used to calculate dose.

Table 9-4 Total Mercury and Radionuclides from American Alligators harvested from the Savannah River near Little Hell Landing (River Mile 135)

\begin{tabular}{|l|c|c|}
\hline & GA-0003766 & SC-12113 \\
\hline Harvest Date & $9 / 24 / 2010$ & $9 / 25 / 2011$ \\
\hline Length & $8 \mathrm{ft} 8 \mathrm{in}$ & $6 \mathrm{ft} 5 \mathrm{in}$ \\
\hline Mercury (ug/g) & 0.70 & 0.50 \\
\hline Americium-241 (pCi/kg) & $\mathrm{ND}$ & $\mathrm{ND}$ \\
\hline Curium-244 (pCi/kg) & $\mathrm{ND}$ & $\mathrm{ND}$ \\
\hline Cobalt-60 (pCi/kg) & $\mathrm{ND}$ & $\mathrm{ND}$ \\
\hline Cesium-137 (pCi/kg) & 43.3 & 68.9 \\
\hline Potassium-40 (pCi/kg) & 2,070 & 2,690 \\
\hline Neptunium (pCi/kg) & $\mathrm{ND}$ & $\mathrm{ND}$ \\
\hline Plutonium-238 (pCi/kg) & $\mathrm{ND}$ & $\mathrm{ND}$ \\
\hline Plutonium-239 (pCi/kg) & $\mathrm{ND}$ & 0.248 \\
\hline Uranium-234 (pCi/kg) & 1.98 & $\mathrm{ND}$ \\
\hline Uranium-235 (pCi/kg) & $\mathrm{ND}$ & 0.282 \\
\hline Uranium-238 (pCi/kg) & 1.75 & \\
\hline ND - Indicates that isotope was not detectable at significant levels. & \\
\hline
\end{tabular}




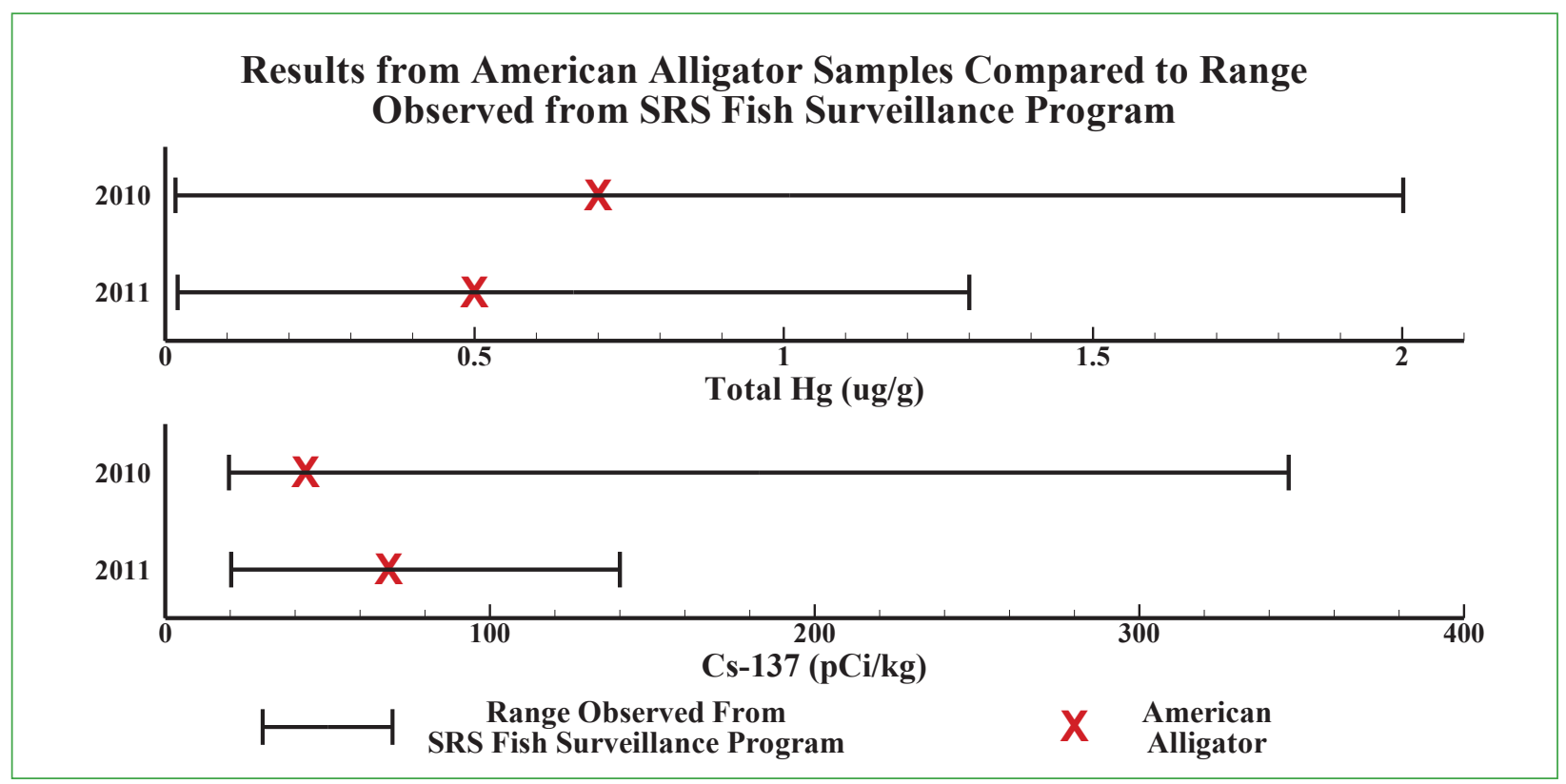

Figure 9-5 Comparison of Mercury and Radionuclides Observed in American Alligator with Range Observed in Edible Fish

\section{Trophic Modeling to Assess Potential Ecological Threats of Ash Deposits in the Wetlands Area at Dunbarton Bay}

During 2012, SRS, in collaboration with the SREL, conducted a special study of the Wetland Area at Dunbarton Bay (WADB) to assess the threat of coal ash deposits to ecological receptors that may inhabit the area. The WADB is currently under investigation through the Federal Facility Agreement because the area received overflow coal ash deposits from P-Area Ash Basin, located upgradient of the WADB. Although most of the WADB is not classified as a wetland, a portion of the unit contains a Carolina bay, a distinctive type of wetland found on the southeastern Atlantic coastal plain characterized by shallow elliptical depressions, oriented northwest to southwest. Although these habitats are now protected on the Site, Carolina bays, in general, have a history of disturbance primarily associated with ditching and draining to support agriculture. Within a regional landscape, Carolina bays offer seasonal or semi-permanent aquatic habitats for foraging and reproduction for a variety of species that are dependent on these isolated wetlands.

In order to evaluate the potential environmental threats of coal ash deposits in the WADB, SRS collected sediment/ soil, surface water, and biological data from the WADB and an unimpacted reference area, Bay 100, located near the WADB. Researchers determined the levels and overall distribution of trace elements/metals from these data. The biological data was used to compare species occurrence and abundance and determine contaminant levels within the biota. Following data analysis, SRS conducted trophic modeling using contaminant exposure models (calculations) that estimate potential contaminant doses to ecological receptors based on contaminant levels in food sources, water, and ingested soil. The trophic level of an organism refers to the organisms' position within the food chain. Higher trophic level organisms (such as a great blue heron) feed high on the food chain and can be more vulnerable to contaminants that bioaccumulate than organisms at a lower trophic level that feed lower on the food chain.

\section{Approach}

SREL collected soil core samples from ten ash depositional areas and two control sites and surface sediment/soil samples from three drift fences in the WADB and three drift fences from Bay 100. Tissue samples were obtained from organisms collected using the drift fences and associated pitfall traps. The organisms were grouped into three categories for the trophic modeling effort: reptiles and amphibians, invertebrates, and small mammals. An additional ten surface sediment/soil and two surface water samples were collected from ash depositional areas within the WADB. 
Samples (sediment/soil, surface water, and biota) were analyzed for trace elements/metals. Figures 9-6 and 9-7 depict organisms collected during the survey.



Figure 9-6

Centipede Collected at the Wetland Area at Dunbarton Bay

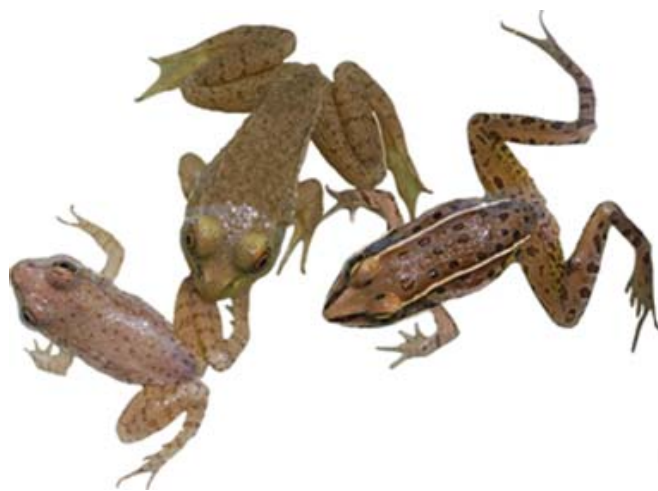

Figure 9-7

Three Species of the Genus Rana (True Frogs) Collected from the WADB Sampling

Effort: Green Frog, Bullfrog, and Leopard Frog (shown left to right)

For the trophic model, the levels of contaminants in the various media (soil, surface water, and biota) were used to evaluate contaminants that pose a potential risk to ecological receptors through the ingestion of the contaminated media. The trophic model used the raccoon Procyon lotor and great blue heron Ardea herodias because these organisms are likely to feed in the habitats of the WADB. The raccoon is omnivorous and commonly forages in wetland and floodplain habitats. The great blue heron, which typically feeds largely on fish, is an opportunistic predator that will also take amphibians, reptiles, small mammals, and invertebrates in wetlands, meadows, and other habitats. The diets of the raccoon and blue heron were adapted to reflect the food items present in wetland habitats. The contaminant burdens calculated from the trophic model were compared with literature-based toxicity data associated with the lowest contaminant level shown to cause an adverse effect such as low survivability or malformations.

\section{Results Summary}

Based on empirical data, biological surveys, and comparisons to the unimpacted reference area, coal ash deposits do not pose a threat to ecological receptors associated with Dunbarton Bay. Results of the trace element/metal analyses showed that levels of arsenic (As), copper ( $\mathrm{Cu}$ ), nickel ( $\mathrm{Ni}$ ), selenium (Se), and strontium ( $\mathrm{Sr}$ ) at locations impacted by ash deposition were elevated when compared with sites outside the ash deposition zone. The results of the modeling effort showed that the ash deposits within the WADB unit do not represent a contaminant risk to predatory birds or omnivorous mammals, which likely represent high exposure receptors for the system. These findings provide further evidence that the contaminants present within the WADB do not pose an ecological threat.

Additionally, biota from the WADB had elevated As, Se, and Sr tissue concentrations compared with biota from Bay 100. Other findings were that biota tissue concentrations were highly correlated with sediment/soil concentrations for As, Se, and Sr. Although tissue concentrations were elevated in biota from the WADB, amphibian species richness and assemblage composition were similar to Bay 100. This suggests an absence of population levels effects to this sensitive bio indicator. 
The raccoon contaminant exposure model showed that aluminum (Al) was the only metal in the WADB with an exposure dose that exceeded the lowest observed adverse effect level (LOAEL) (Figure 9-8). Aluminum also exceeded the exposure dose in Bay 100. The large majority of the $\mathrm{Al}$ intake in both areas was from incidental soil consumption.

Aluminum exceedances for mammals (raccoon and river otter) have been observed in other SRS sites, including reference areas that are unaffected by SRS operations. These exceedances are likely related to naturally high Al levels in SRS soils. Kaolinite $\left[\mathrm{Al}_{2} \mathrm{Si}_{2} \mathrm{O}_{5}(\mathrm{OH})_{4}\right]$ is mined in the region and is a

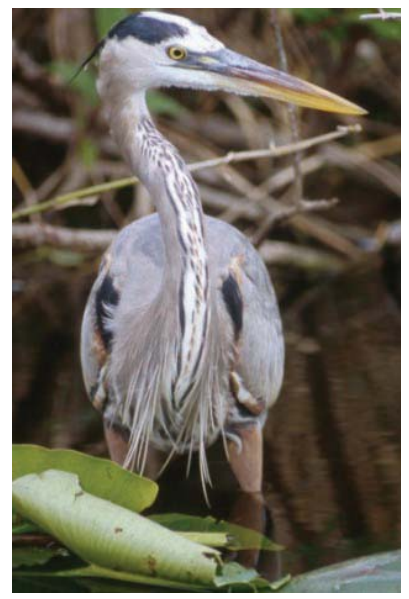

Figure 9-9

Photo of Great Blue Huron (Ardea herodia) at SRS

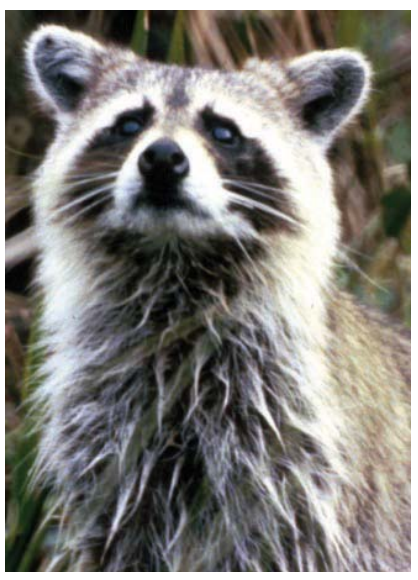

Figure 9-8

Photo of a Raccoon (Procyon lotor) at SRS on contaminant exposure model was the result of a higher Al LOAEL for birds (great blue heron) than for mammals (raccoon).

Since Al was the only metal that exceeded toxicity reference values, and Al exceedances in SRS soils are common, even in reference areas, it is likely the high Al levels in SRS soils are related to naturally elevated levels in soils rather than to the ash deposits within the WADB.

Results of the study are documented in the Focused Corrective Measures Study/Feasibility Study Report (CMS/FS) for the Wetland Area at Dunbarton Bay in Support of the Steel Creek Integrator Operable Unit, (SRNS, 2012a).

\section{Special Study of Mercury and Tin in the Tims Branch Ecosystem}

In 2012, a multi-organizational research team completed the initial phase of research in a special study of Tims Branch (Looney et al., 2012). The project aims to evaluate and quantify the impacts of an innovative, inexpensive treatment system that removes mercury from water. In this treatment, mercury reacts with stannous (tin) chloride and then air stripping removes the mercury from the water, a technology that treats volatile contaminants.

Starting in November 2007, this system operated continuously at fullscale in M Area treating 400 to 500 gallons per minute (gpm) of water containing about $250 \mathrm{ng}$ of mercury per liter (ng/L or parts per trillion). Figure 9-10 shows the air stripper. Mercury in the raw water is below the human drinking water standard of 2,000 $\mathrm{ng} / \mathrm{L}$, but higher than the ecological and recreational use-based water quality limits set for the outfall (51 ng/L). The long-term aim of implementing the outfall limits in 2007 was to lower mercury levels in downstream fish.

Mercury levels in the treated water released to the environment have been reduced more than 95\%, achieving the strict ecological and recreational use-based water quality limits.

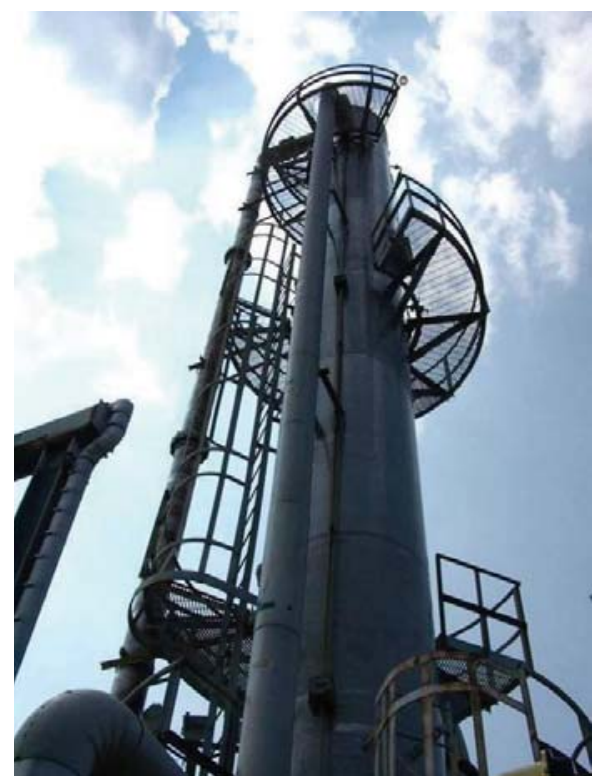

Figure 9-10

SRS Modified the M-1 Stripper System in 2007 to Remove Mercury 


\section{Approach}

The DOE Office of Environmental Management sponsored a 2010 to 2013 study of the downstream impacts of the first several years of mercury treatment in Tims Branch, the small SRS stream that receives the treated water.

Researchers from the Savannah River National Laboratory (SRNL), SREL, and Oak Ridge National Laboratory (ORNL), along with a student from Florida International University, contributed to the research (as shown in Figure 9-11 to 9-13). The research has generated a significant data set for two elements in the Tims Branch ecosystem, mercury, and tin:

- Mercury bioaccumulates, or builds up in aquatic food chains. The research team measured mercury concentrations in several components of the aquatic ecosystem including water, sediment, biofilm, invertebrates, and fish. Confirming a significant reduction in mercury concentration in fish would provide an initial indication of the success of the treatment process in achieving the desired environmental benefits.

- Tin is released to the ecosystem as a byproduct of the mercury treatment. The anticipated form of tin (inorganic tin oxide particles) is not expected to impact the stream and the low concentrations of tin are below regulatory limits. Confirming the anticipated tin behavior in the ecosystem by measuring tin concentrations in the various ecosystem components would help assure that the treatment is not generating any unexpected adverse impacts.

All of the data from 2010 and later were compared to data from samples collected prior to the installation of the treatment system.

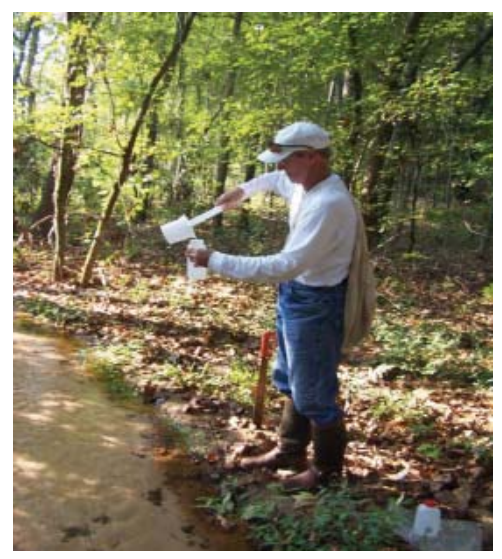

Figure 9-11

A SRNL Scientist Collects Water Samples from Tims Branch

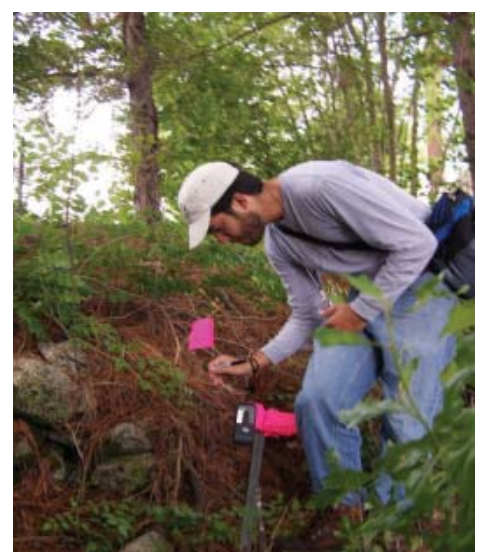

Figure 9-12

A Florida International

University Student Marks a Sampling Location along Tims Branch

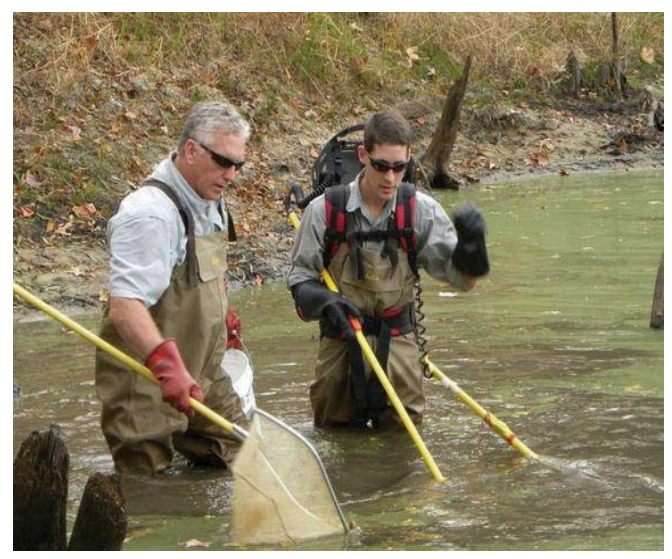

Figure 9-13

Oak Ridge Scientists Collect Fish Samples in 2011 to Support Research on the Impacts of the Mercury Treatment in Tims Branch

\section{Results Summary}

Water treatment is having the desired impact on the primary ecological endpoint, fish concentrations, with mercury levels in fish decreasing as the element clears from the ecosystem. Initial mercury data indicate that first few years of mercury treatment resulted in a significant decrease in mercury concentration in an upper trophic level fish-redfin pickerel - at all sampling locations in the impacted reach of Tims Branch. For example, the whole body mercury concentrations in redfin pickerel collected from the pond just downstream of the outfall decreased approximately $72 \%$ between 2006 (pre-treatment) and 2010 (post-treatment). Over this same period, mercury concentrations in the fillet of redfin pickerel in this pond decreased from approximately $1.45 \mu \mathrm{g} / \mathrm{g}$ (wet weight basis) to $0.45 \mu \mathrm{g} / \mathrm{g}$. Initial data for tin confirmed that a majority of this element discharged into Tims Branch is "inert" tin oxide particles that should not accumulate in fish. 
All of the data from the initial phase of work are reported in the Interim Results from a Study of the Impacts of Tin (II) Based Mercury Treatment in a Small Stream Ecosystem: Tims Branch, (Looney et al. 2012).

The initial results of this screening study indicate that the treatment process is performing as predicted. Importantly, the concentration of mercury in upper trophic level fish, as a surrogate for all of the underlying transport and transformation processes in a complex real-world ecosystem, has declined as a direct result of the elimination of mercury inputs into Tims Branch. Inorganic tin released to the ecosystem has been found in compartments where particles accumulate (such as sediment and biofilms). The team plans to complete the final planned phase of research in 2013. 
This page intentionally left blank. 


\section{APPENDIX A - \\ RADIONUCLIDE AND \\ CHEMICAL NOMENCLATURE}

\begin{tabular}{|c|c|c|c|c|c|}
\hline \multicolumn{6}{|c|}{ Nomenclature and Half-Life for Radionuclides } \\
\hline Radionuclides & Symbol & Half-life $\mathrm{e}^{\mathrm{a}, \mathrm{b}}$ & Radionuclide & Symbol & Half-life $^{a, b}$ \\
\hline Actinium-228 & Ac-228 & $6.15 \mathrm{~h}$ & Iodine-129 & $\mathrm{I}-129$ & $1.57 \times 10^{7} \mathrm{y}$ \\
\hline Americium-241 & Am-241 & $432.7 \mathrm{y}$ & Iodine-131 & $\mathrm{I}-131$ & $8.020 \mathrm{~d}$ \\
\hline Americium-243 & Am-243 & $7.37 \times 10^{3} y$ & Iodine-133 & $\mathrm{I}-133$ & $20.8 \mathrm{~h}$ \\
\hline Antimony-124 & Sb-124 & $60.20 \mathrm{~d}$ & Krypton-85 & Kr-85 & $10.76 \mathrm{y}$ \\
\hline Antimony-125 & Sb-125 & $2.758 \mathrm{y}$ & Lead-212 & $\mathrm{Pb}-212$ & $10.64 \mathrm{~h}$ \\
\hline Argon-39 & Ar-39 & $269 \mathrm{y}$ & Lead-214 & $\mathrm{Pb}-214$ & $27 \mathrm{~m}$ \\
\hline Barium-133 & Ba-133 & $10.53 \mathrm{y}$ & Manganese-54 & Mn-54 & $312.1 \mathrm{~d}$ \\
\hline Beryllium-7 & Be-7 & $53.3 \mathrm{~d}$ & Mercury-203 & Hg-203 & $46.61 \mathrm{~d}$ \\
\hline Bismuth-212 & Bi-212 & $1.009 \mathrm{~h}$ & Neptunium-237 & Np-237 & $2.14 \times 10^{6} \mathrm{y}$ \\
\hline Bismuth-214 & $\mathrm{Bi}-214$ & $19.9 \mathrm{~m}$ & Neptunium-239 & Np-239 & $2.355 \mathrm{~d}$ \\
\hline Carbon-14 & C-14 & $5715 \mathrm{y}$ & \begin{tabular}{|l|} 
Nickel-59 \\
\end{tabular} & Ni-59 & $7.6 \times 10^{4} \mathrm{y}$ \\
\hline Cerium-141 & Ce-141 & $32.50 \mathrm{~d}$ & Nickel-63 & Ni-63 & $101 \mathrm{y}$ \\
\hline Cerium-144 & Ce-144 & $284.6 \mathrm{~d}$ & Niobium-94 & Nb-94 & $2.0 \times 10^{4} \mathrm{y}$ \\
\hline Cesium-134 & Cs-134 & $2.065 \mathrm{y}$ & Niobium-95 & Nb-95 & $34.99 \mathrm{~d}$ \\
\hline Cesium-137 & Cs-137 & $30.07 \mathrm{y}$ & Plutonium-238 & Pu-238 & $87.7 \mathrm{y}$ \\
\hline Chromium-51 & Cr-51 & $27.702 \mathrm{~d}$ & Plutonium-239 & Pu-239 & $2.41 \times 10^{4} \mathrm{y}$ \\
\hline Cobalt-57 & Co-57 & $271.8 \mathrm{~d}$ & Plutonium-240 & Pu-240 & $6.56 \times 10^{3} \mathrm{y}$ \\
\hline Cobalt-58 & Co-58 & $70.88 \mathrm{~d}$ & Plutonium-241 & Pu-241 & $14.4 \mathrm{y}$ \\
\hline Cobalt-60 & Co-60 & $5.271 \mathrm{y}$ & \begin{tabular}{|l} 
Plutonium-242 \\
\end{tabular} & Pu-242 & $3.75 \times 10^{5} \mathrm{y}$ \\
\hline Curium-242 & Cm-242 & $162.8 \mathrm{~d}$ & Potassium-40 & K-40 & $1.27 \times 10^{9} \mathrm{y}$ \\
\hline Curium-244 & Cm-244 & $18.1 \mathrm{y}$ & Praseodymium-144 & Pr-144 & $17.28 \mathrm{~m}$ \\
\hline Curium-245 & Cm-245 & $8.5 \times 10^{3} \mathrm{y}$ & Praseodymium-144m & Pr- $144 \mathrm{~m}$ & $7.2 \mathrm{~m}$ \\
\hline Curium-246 & Cm-246 & $4.76 \times 10^{3} \mathrm{y}$ & Promethium-147 & Pm-147 & $2.6234 \mathrm{y}$ \\
\hline Europium-152 & Eu-152 & $13.54 \mathrm{y}$ & Protactinium-231 & Pa-231 & $3.28 \times 10^{4} \mathrm{y}$ \\
\hline Europium-154 & Eu-154 & $8.593 \mathrm{y}$ & Protactinium-233 & Pa-233 & $26.967 \mathrm{~d}$ \\
\hline Europium-155 & Eu-155 & $4.75 \mathrm{y}$ & Protactium-234 & Pa-234 & $6.69 \mathrm{~h}$ \\
\hline
\end{tabular}




\begin{tabular}{|c|c|c|c|c|c|}
\hline \multicolumn{6}{|c|}{ Nomenclature and Half-Life for Radionuclides (Continued) } \\
\hline Radionuclides & Symbol & Half-life $\mathrm{e}^{\mathrm{a}, \mathrm{b}}$ & Radionuclide & Symbol & Half-life ${ }^{\mathrm{a}, \mathrm{b}}$ \\
\hline Radium-226 & Ra-226 & $1599 \mathrm{y}$ & Thorium-234 & Th-234 & $24.10 \mathrm{~d}$ \\
\hline Radium-228 & Ra-228 & $5.76 \mathrm{y}$ & Tin-113 & Sn-113 & $115.1 \mathrm{~d}$ \\
\hline Ruthenium-103 & Ru-103 & $39.27 \mathrm{~d}$ & Tin-126 & Sn-126 & $2.3 \mathrm{x} 10^{5} \mathrm{y}$ \\
\hline Ruthenium-106 & Ru-106 & $1.020 \mathrm{y}$ & Tritium (Hydrogen-3) & $\mathrm{H}-3$ & $12.32 \mathrm{y}$ \\
\hline Selenium-75 & Se-75 & $119.78 \mathrm{~d}$ & Uranium-232 & $\mathrm{U}-232$ & $69.8 \mathrm{y}$ \\
\hline Selenium-79 & Se-79 & $2.9 \times 10^{5} \mathrm{y}$ & Uranium-233 & U-233 & $1.592 \times 10^{5} \mathrm{y}$ \\
\hline Sodium-22 & $\mathrm{Na}-22$ & $2.604 \mathrm{y}$ & Uranium-234 & U-234 & $2.46 \times 10^{5} \mathrm{y}$ \\
\hline Strontium-89 & Sr-89 & $50.52 \mathrm{~d}$ & Uranium-235 & U-235 & $7.04 \times 10^{8} \mathrm{y}$ \\
\hline Strontium-90 & Sr-90 & $28.78 \mathrm{y}$ & Uranium-236 & U-236 & $2.342 \times 10^{7} \mathrm{y}$ \\
\hline Technetium-99 & Tc-99 & $2.13 \times 10^{5} \mathrm{y}$ & Uranium-238 & U-238 & $4.47 \times 10^{9} \mathrm{y}$ \\
\hline Thallium-208 & Tl-208 & $3.053 \mathrm{~m}$ & Xenon-135 & Xe-135 & $9.10 \mathrm{~h}$ \\
\hline Thorium-228 & Th-228 & $1.912 \mathrm{y}$ & Zinc-65 & Zn-65 & $243.8 \mathrm{~d}$ \\
\hline Thorium-230 & Th-230 & $7.54 \times 10^{4} \mathrm{y}$ & Zinconium-85 & Zr-85 & $7.9 \mathrm{~m}$ \\
\hline Thorium-232 & Th-232 & $1.40 \mathrm{x} 10^{10} \mathrm{y}$ & Zinconium-95 & Zr-95 & $64.02 \mathrm{~d}$ \\
\hline
\end{tabular}




\section{APPENDIX B - ERRATA}

The following entries correct information that was reported inaccurately in the Savannah River Site Environmental Report for 2011 (SRNS-STI-2012-00200):

- During a routine test, it was discovered that CAP88 PC version 3.0 (December 9, 2007) was not producing the expected results when using multiple co-located stacks in a single run. This issue was corrected by the Environmental Protection Agency (EPA) in the February 9, 2013 version 3.0. EPA also updated the vegetation deposition calculation.

- The total potential dose to the maximally exposed individual from Savannah River Site (SRS) atmospheric releases in 2011 using CAP88 PC version 3.0 (February 9, 2013) is 5.62x10-2 mrem/year. The total dose reported in the report for 2011 using the December 9, 2007 version was 1.50x10-2 mrem/year.

- The total potential collective dose from SRS atmospheric releases in 2011 using CAP88 PC ver. 3.0 (February 9, 2013) is 5.10 person-rem/year. The total potential collective dose reported in the report for 2011 using the December 9, 2007 version was 1.90 person-rem/year.

- The graph presented in the report for 2011, Figure 5-4 depicts data for Pen Branch and Fourmile Branch. The title for the graph is Ten-Year Trend of Average Tritium Concentration in Lower Three Runs, Steel Creek, and Upper Three Runs (pCi/L). The correct graph for Lower Three Runs, Steel Creek and Upper Three Runs is provided below.

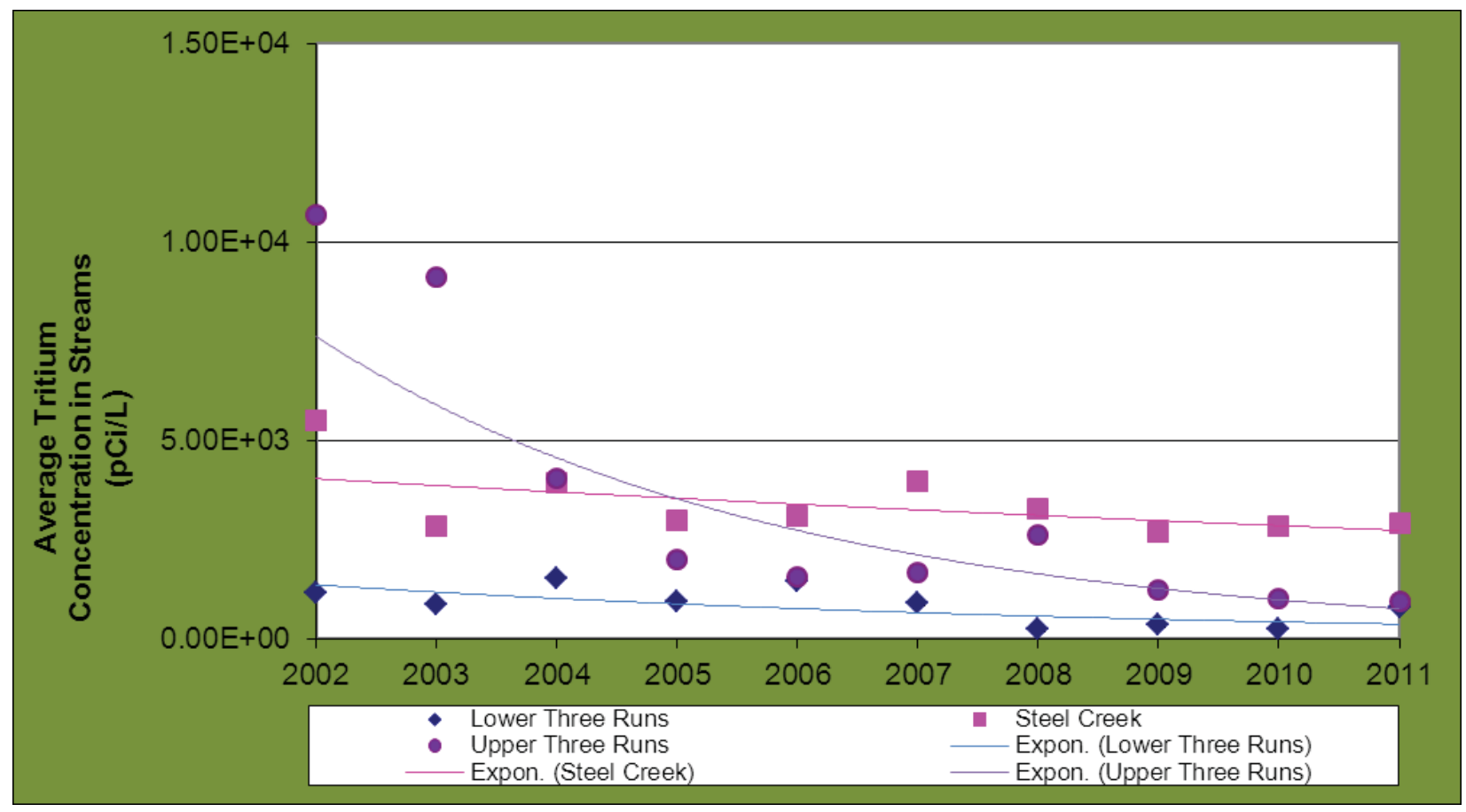


This page intentionally left blank. 


\section{GLOSSARY}

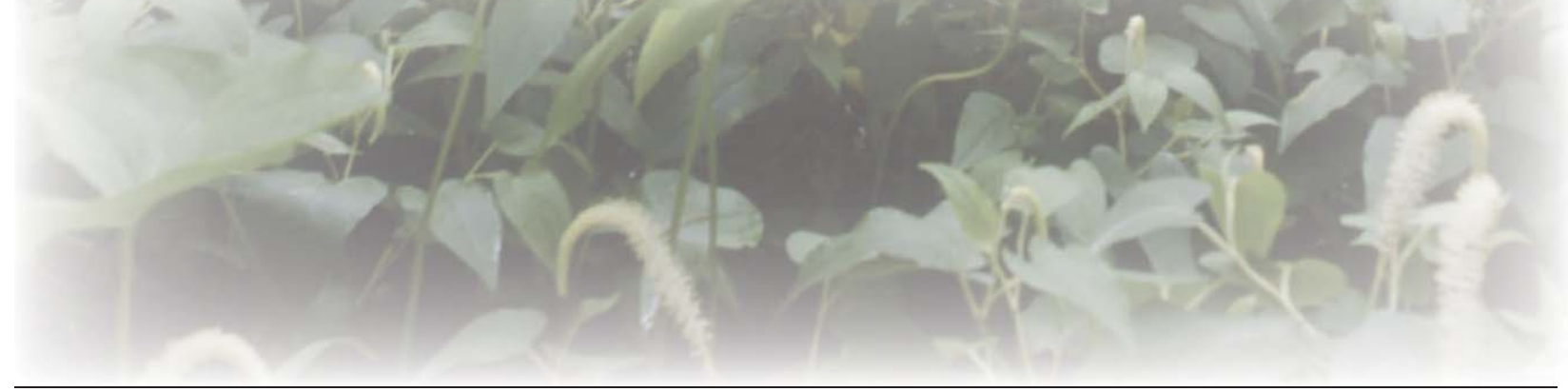

A

accuracy - Closeness of the result of a measurement to the true value of the quantity.

actinide - Group of elements of atomic number 89 through 103. Laboratory analysis of actinides by alpha spectrometry generally refers to the elements plutonium, americium, uranium, and curium but may also include neptunium and thorium.

activity - See radioactivity.

air flow - Rate of flow, measured by mass or volume per unit of time.

air stripping - Process used to decontaminate groundwater by pumping the water to the surface, "stripping” or evaporating the chemicals in a specially designed tower, and pumping the cleansed water back to the environment.

ALARA - As Low As Reasonably Achievable. A documented process that is implemented to optimize control and management of radiological activities so that doses to the public and releases to the environment are kept ALARA.

aliquot - Quantity of sample being used for analysis.

alkalinity - Alkalinity is a measure of the buffering capacity of water, and since $\mathrm{pH}$ has a direct effect on organisms as well as an indirect effect on the toxicity of certain other pollutants in the water, the buffering capacity is important to water quality.

alpha particle - Positively charged particle emitted from the nucleus of an atom having the same charge and mass as that of a helium nucleus (two protons and two neutrons)

ambient air - Surrounding atmosphere as it exists around people, plants, and structures.

analyte - Constituent or parameter that is being analyzed.

analytical detection limit - Lowest reasonably accurate concentration of an analyte that can be detected; this value varies depending on the method, instrument, and dilution used.

aquifer - Saturated, permeable geologic unit that can transmit significant quantities of water under ordinary hydraulic gradients.

aquitard - Geologic unit that inhibits the flow of water.

Area Completion Program - U.S. Department of Energy program that directs the assessment and cleanup of inactive waste units and groundwater (remediation) contaminated as a result of nuclear-related activities. 
Atomic Energy Commission - Federal agency created in 1946 to manage the development, use, and control of nuclear energy for military and civilian application. It was abolished by the Energy Reorganization Act of 1974 and succeeded by the Energy Research and Development Administration. Functions of the Energy Research and Development Administration eventually were taken over by the U.S. Department of Energy and the U.S. Nuclear Regulatory Commission.

\section{B}

background radiation - Naturally occurring radiation, fallout, and cosmic radiation. Generally, the lowest level of radiation obtainable within the scope of an analytical measurement, i.e., a blank sample.

bailer - Container lowered into a well to remove water. The bailer is allowed to fill with water and then is removed from the well.

best management practices - Sound engineering practices that are not required by regulation or by law.

beta particle - Negatively charged particle emitted from the nucleus of an atom. It has a mass and charge equal to those of an electron.

blank - A sample that has not been exposed to the sample stream in order to monitor contamination during sampling, transport, storage, or analysis. The blank is subjected to the usual analytical and measurement process to establish a zero-baseline or-background value, and sometimes is used to adjust or correct routine analytical results.

blind blank - Sample container of deionized water sent to a laboratory under an alias name as a quality control check.

blind replicate - A second sample taken from the same well at the same time as the primary sample, assigned an alias well name, as a quality control check.

blind sample - A subsample for analysis with a composition known to the submitter. The analyst/laboratory may know the identity of the sample, but not its composition. It is used to test the analyst's or laboratory's proficiency in the execution of the measurement process.

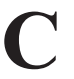

calibration - Process of applying correction factors to equate a measurement to a known standard. Generally, a documented measurement control program of charts, graphs, and data that demonstrate that an instrument is properly calibrated.

Carolina bay - Type of shallow depression commonly found on the coastal Carolina plains. Carolina bays are typically circular or oval. Some are wet or marshy, while others are dry.

Central Savannah River Area (CSRA) - Eighteen-county area in Georgia and South Carolina surrounding Augusta, Georgia. The Savannah River Site is included in the Central Savannah River Area. Counties are Richmond, Columbia, McDuffie, Burke, Emanuel, Glascock, Jenkins, Jefferson, Lincoln, Screven, Taliaferro, Warren, and Wilkes in Georgia and Aiken, Edgefield, Allendale, Barnwell, and McCormick in South Carolina.

chemical oxygen demand - Indicates the quantity of oxidizable materials present in water.

chlorocarbons - Compounds of carbon and chlorine, or carbon, hydrogen, and chlorine, such as carbon tetrachloride, chloroform, tetrachloroethylene, etc. They are among the most significant and widespread environmental contaminants. Classified as hazardous wastes, chlorocarbons may have a tendency to cause detrimental effects, such as birth defects. 
cleanup - Actions taken to deal with release or potential release of hazardous substances. This may mean complete removal of the substance; it also may mean stabilizing, containing, or otherwise treating the substance so that it does not affect human health or the environment.

closure - Control of a hazardous waste management facility under Resource Conservation and Recovery Act requirements.

compliance - Fulfillment of applicable requirements of a plan or schedule ordered or approved by government authority.

composite - A blend of more than one portion to be used as a sample for analysis.

Comprehensive Environmental Response, Compensation, and Liability Act (CERCLA) - This Act addresses the cleanup of hazardous substances and establishes a National Priority List of sites targeted for assessment and, if necessary, restoration (commonly known as "Superfund").

Comprehensive Environmental Response, Compensation, and Liability Act (CERCLA) reportable release - Release to the environment that exceeds reportable quantities as defined by the Comprehensive Environmental Response, Compensation, and Liability Act.

concentration - Amount of a substance contained in a unit volume or mass of a sample.

conductivity - Measure of water's capacity to convey an electric current. This property is related to the total concentration of the ionized substances in water and the temperature at which the measurement is made.

contamination - State of being made impure or unsuitable by contact or mixture with something unclean, bad, etc.

count - Signal that announces an ionization event within a counter; a measure of the radiation from an object or device.

counting geometry - Well-defined sample size and shape for which a counting system has been calibrated.

criteria pollutant - Six common air pollutants found all over the United States. They are particle pollution (often referred to as particulate matter), ground-level ozone, carbon monoxide, sulfur dioxide, nitrogen oxides, and lead. EPA is required by the Clean Air Act to set National Ambient Air Quality Standards for these six pollutants.

cross talk - The fraction of all recorded pulses from alpha particles that are recorded in the beta channel due to degradation in their pulse height or the fraction of all recorded pulses from beta particles that are recorded in the alpha channel due to pulse pileup or other phenomenon.

curie - Unit of radioactivity. One curie is defined as 3.7 x 1010 (37 billion) disintegrations per second. Several fractions and multiples of the curie are commonly used:

- $\quad$ kilocurie (kCi) $-10^{3} \mathrm{Ci}$, one thousand curies; $3.7 \times 10^{13}$ disintegrations per second.

- millicurie ( $\mathbf{m C i})-10^{-3} \mathrm{Ci}$, one-thousandth of a curie; $3.7 \times 10^{7}$ disintegrations per second.

- microcurie $(\mu \mathrm{Ci})-10^{-6} \mathrm{Ci}$, one-millionth of a curie; $3.7 \times 10^{4}$ disintegrations per second.

- $\quad$ picocurie (pCi) $-10^{-12} \mathrm{Ci}$, one-trillionth of a curie; 0.037 disintegrations per second. 
D

decay (radioactive) - Spontaneous transformation of one radionuclide into a different radioactive or nonradioactive nuclide, or into a different energy state of the same radionuclide.

decay time - Time taken by a quantity to decay to a stated fraction of its initial value.

deactivation - The process of placing a facility in a stable and known condition, including the removal of hazardous and radioactive materials to ensure adequate protection of the worker, public health and safety, and the environment, thereby limiting the long-term cost of surveillance and maintenance.

decommissioning - Process that takes place after deactivation and includes surveillance and maintenance, decontamination, and/or dismantlement.

decontamination - The removal or reduction of residual radioactive and hazardous materials by mechanical, chemical, or other techniques to achieve a stated objective or end condition.

decommissioning and demolition - Program that reduces the environmental and safety risks of surplus facilities at SRS.

derived concentration standard - Concentration of a radionuclide in air or water that, under conditions of continuous exposure for one year by one exposure mode (i.e., ingestion of water, submersion in air, or inhalation), would result in either an effective dose equivalent of $0.1 \mathrm{rem}(1 \mathrm{mSv})$ The guides for radionuclides in air and water are given in U.S. Department of Energy Derived Concentration Technical Standard (DOE-STD-1196-2011)

detection limit - See analytical detection limit, lower limit of detection, minimum detectable concentration.

detector - Material or device (instrument) that is sensitive to radiation and can produce a signal suitable for measurement or analysis.

diatometer - Diatom collection equipment consisting of a series of microscope slides in a holder that is used to determine the amount of algae in a water system.

diatoms - Unicellular or colonial algae of the class Bacillariophyceae, having siliceous cell walls with two overlapping, symmetrical parts. Diatoms represent the predominant periphyton (attached algae) in most water bodies and have been shown to be reliable indicators of water quality.

direct push - A direct-push machine pushes tools and sensors into the ground without the use of drilling to remove soil.

disposal - Permanent or temporary transfer of U.S. Department of Energy control and custody of real property to a third party, which thereby acquires rights to control, use, or relinquish the property.

disposition - Those activities that follow completion of program mission-including, but not limited to, surveillance and maintenance, deactivation, and decommissioning.

dissolved oxygen - Desirable indicator of satisfactory water quality in terms of low residuals of biologically available organic materials. Dissolved oxygen prevents the chemical reduction and subsequent leaching of iron and manganese from sediments. 
dose - Energy imparted to matter by ionizing radiation. The unit of absorbed dose is the rad, equal to 0.01 joules per kilogram in any medium.

- absorbed dose - Quantity of radiation energy absorbed by an organ, divided by the organ's mass. Absorbed dose is expressed in units of rad (or gray) (l rad = 0.01 Gy).

- equivalent dose - Product of the absorbed dose (rad) in tissue and a radiation weighting factor. Equivalent dose is expressed in units of rem (or sievert) ( 1 rem $=0.01$ sievert).

- effective dose - Sum of the dose equivalents received by all organs or tissues of the body after each one has been multiplied by an appropriate tissue weighting factor.

- committed effective dose - Is the effective dose integrated over time, usually 50-years. Committed effective dose is expressed in units of rem (or sievert).

- collective dose - Sum of the effective dose of all individuals in an exposed population within a 50-mile (80-km) radius, and expressed in units of person-rem (or person-sievert). The 50-mile distance is measured from a point located centrally with respect to major facilities or U.S. Department of Energy program activities.

dosimeter - Portable detection device for measuring the total accumulated exposure to ionizing radiation.

downgradient - In the direction of decreasing hydrostatic head.

drinking water standards - Federal primary drinking water standards, both proposed and final, as set forth by the Environmental Protection Agency.

duplicate result - Result derived by taking a portion of a primary sample and performing the identical analysis on that portion as is performed on the primary sample.

\section{$\mathbf{E}$}

effluent - Any treated or untreated air emission or liquid discharge to the environment.

effluent monitoring - Collection and analysis of samples or measurements of liquid and gaseous effluents for purpose of characterizing and quantifying the release of contaminants, assessing radiation exposures to members of the public, and demonstrating compliance with applicable standards.

environmental compliance - Actions taken in accordance with government laws, regulations, orders, etc., that apply to Site operations' effects on onsite and offsite natural resources and on human health; used interchangeably in this document with regulatory compliance.

environmental monitoring - Program at Savannah River Site that includes effluent monitoring and environmental surveillance with dual purpose of l) showing compliance with federal, state, and local regulations, as well as with U.S. Department of Energy orders, and 2) monitoring any effects of Site operations on onsite and offsite natural resources and on human health.

environmental surveillance - Collection and analysis of samples of air, water, soil, foodstuffs, biota, and other media from U.S. Department of Energy sites and their environs and the measurement of external radiation for purpose of demonstrating compliance with applicable standards, assessing radiation exposures to members of the public, and assessing effects, if any, on the local environment.

exception (formerly "exceedance") - Term used by the Environmental Protection Agency and the South Carolina Department of Health and Environmental Control that denotes a report value is more than the upper guide limit. This term is found on the discharge monitoring report forms that are submitted to the Environmental Protection Agency or the South Carolina Department of Health and Environmental Control. 
exposure (radiation) - Incidence of radiation on living or inanimate material by accident or intent. Background exposure is the exposure to natural background ionizing radiation. Occupational exposure is the exposure to ionizing radiation that takes place during a person's working hours. Population exposure is the exposure to the total number of persons who inhabit an area.

exposure pathway - Route that materials follow to get to the environment and then to people.

$\mathbf{F}$

fallout - See worldwide fallout.

Federal Facility Agreement (FFA) - Agreement negotiated among the U.S. Department of Energy, the U.S. Environmental Protection Agency, and the South Carolina Department of Health and Environmental Control, specifying how the Savannah River Site will address contamination or potential contamination to meet regulatory requirements at Site waste units identified for evaluation and, if necessary, cleanup.

feral hog - Hog that has reverted to the wild state from domestication.

field duplicates - Independent samples collected as closely as possible to the same point in space and time. They are two separate samples taken from the same source, stored in separate containers, and analyzed independently.

G

gamma ray - High-energy, short-wavelength electromagnetic radiation emitted from the nucleus of an excited atom. Gamma rays are identical to X-rays except for the source of the emission.

gamma-emitter - Any nuclide that emits a gamma ray during the process of radioactive decay. Generally, the fission products produced in nuclear reactors.

gamma spectrometry - System consisting of a detector, associated electronics, and a multichannel analyzer that is used to analyze samples for gamma-emitting radionuclides.

grab sample - Sample collected instantaneously with a glass or plastic bottle placed below the water surface to collect surface water samples (also called dip samples).

\section{H}

half-life (radiological) - Time required for half of a given number of atoms of a specific radionuclide to decay. Each nuclide has a unique half-life.

heavy water - Water in which the molecules contain oxygen and deuterium, an isotope of hydrogen that is heavier than ordinary hydrogen.

hydraulic gradient - Difference in hydraulic head over a specified distance.

hydrology - Science that treats the occurrence, circulation, distribution, and properties of the waters of the earth, and their reaction with the environment. 
$\mathbf{L}$

laboratory blank - Deionized water sample generated by the laboratory; a laboratory blank is analyzed with each batch of samples as an in-house check of analytical procedures. Also called an internal blank.

laboratory control sample - A sample matrix, free from the analytes of interest, spiked with verified known amounts of analytes or a material containing known and verified amounts of analytes. It generally is used to establish intralaboratory or analyte-specific precision and bias, or to assess the performance of all or a portion of the measurement system.

laboratory duplicate - Aliquot of a sample taken from the same container under laboratory conditions and processed and analyzed independently.

legacy - Anything handed down from the past; inheritance, as of nuclear waste.

lower limit of detection - Smallest concentration/amount of an analyte that can be reliably detected in a sample at a 95-percent confidence level.

M

macroinvertebrates - Size-based classification used for a variety of insects and other small invertebrates; as defined by the U.S. Environmental Protection Agency, those organisms that are retained by a No. 30 (590-micron) U.S. standard sieve.

macrophyte - A plant that can be observed with the naked eye.

manmade radiation - Radiation from sources such as consumer products, medical procedures, and nuclear industry.

maximally exposed individual - Hypothetical individual who remains in an uncontrolled area and would, when all potential routes of exposure from a facility's operations are considered, receive the greatest possible dose equivalent.

maximum contaminant level - The maximum allowable concentration of a drinking water contaminant as legislated through the Safe Drinking Water Act.

mean relative difference - Percentage error based on statistical analysis.

mercury - Silver-white, liquid metal solidifying at $-38.9^{\circ} \mathrm{C}$ to form a tin-white, ductile, malleable mass. It is widely distributed in the environment and biologically is a nonessential or nonbeneficial element. Human poisoning due to this highly toxic element has been clinically recognized.

migration - Transfer or movement of a material through the soil or groundwater.

minimum detectable concentration - Smallest amount or concentration of a radionuclide that can be distinguished in a sample by a given measurement system at a preselected counting time and at a given confidence level.

moderate - To reduce the excessiveness of; to act as a moderator.

moderator - Material, such as heavy water, used in a nuclear reactor to moderate or slow down neutrons from the high velocities at which they are created in the fission process.

monitoring - Process whereby the quantity and quality of factors that can affect the environment and/or human health are measured periodically to regulate and control potential impacts. 
N

nonroutine radioactive release - Unplanned or nonscheduled release of radioactivity to the environment.

nuclide - Atom specified by its atomic weight, atomic number, and energy state. A radionuclide is a radioactive nuclide.

O

opacity - The reduction in visibility of an object or background as viewed through the diameter of a plume.

organic - Of, relating to, or derived from living organisms (plant or animal).

outcrop - Place where groundwater is discharged to the surface. Springs, swamps, and beds of streams and rivers are the outcrops of the water table.

outfall - Point of discharge (e.g., drain or pipe) of wastewater or other effluents into a ditch, pond, or river.

$\mathbf{P}$

parameter - Analytical constituent; chemical compound(s) or property for which an analytical request may be submitted.

permeability - Physical property that describes the ease with which water may move through the pore spaces and cracks in a solid.

person-rem - Collective dose to a population group. For example, a dose of one rem to 10 individuals results in a collective dose of 10 person-rem.

pH - Measure of the hydrogen ion concentration in an aqueous solution (acidic solutions, $\mathrm{pH}<7$; basic solutions, $\mathrm{pH}$ >7; and neutral solutions, $\mathrm{pH} 7$ ).

piezometer - Instrument used to measure the potentiometric surface of the groundwater. Also, a well designed for this purpose.

plume - Volume of contaminated air or water originating at a point-source emission (e.g., a smokestack) or at a waste source (e.g., a hazardous waste disposal site).

point source - Any defined source of emission to air or water such as a stack, air vent, pipe, channel, or passage to a water body.

population dose - See collective dose equivalent under dose.

process sewer - Pipe or drain, generally located underground, used to carry off process water and/or waste matter.

purge - To remove water prior to sampling, generally by pumping or bailing. 


\section{Q}

quality assurance (QA) - QA focuses on minimizing errors through ongoing assessment and control of the program components to produce data of proven and known quality.

quality control (QC) - QC refers to those tests and checks that ensure compliance with defined standards to ensure that the data produced are generated within known probability limits of accuracy and precision.

\section{$\mathbf{R}$}

rad - Unit of absorbed dose deposited in a volume of material

radioactivity - Spontaneous emission of radiation, generally alpha or beta particles, or gamma rays, from the nucleus of an unstable isotope.

radioisotopes - Radioactive isotopes.

radionuclide - Unstable nuclide capable of spontaneous transformation into other nuclides by changing its nuclear configuration or energy level. This transformation is accompanied by the emission of photons or particles.

real-time instrumentation - Operation in which programmed responses to an event essentially are simultaneous to the event itself.

reforestation - Process of planting new trees on land once forested.

regulatory compliance - Actions taken in accordance with government laws, regulations, orders, etc., that apply to Savannah River Site operations' effects on onsite and offsite natural resources and on human health; used interchangeably in this document with environmental compliance.

release - Any discharge to the environment. Environment is broadly defined as any water, land, or ambient air.

rem - Unit of dose equivalent (absorbed dose in rads times the radiation quality factor). Dose equivalent frequently is reported in units of millirem (mrem), which is one thousandth of a rem.

remediation - Assessment and cleanup of U.S. Department of Energy sites contaminated with waste as a result of past activities. See environmental restoration.

remediation design - Planning aspects of remediation, such as engineering characterization, sampling studies, data compilation, and determining a path forward for a waste site.

replicate - In the SRS groundwater monitoring program, a second sample from the same well taken at the same time as the primary sample and sent to the same laboratory for analysis.

Representative Person - An individual receiving a dose that is representative of the more highly exposed individuals in the population.

Resource Conservation and Recovery Act (RCRA) - Federal legislation that regulates the transport, treatment, and disposal of solid and hazardous wastes. This act also requires corrective action for releases of hazardous waste at inactive waste units.

Resource Conservation and Recovery Act (RCRA) site - Solid waste management unit under Resource Conservation and Recovery Act regulation. See Resource Conservation and Recovery Act. 
retention basin - Unlined basin used for emergency, temporary storage of potentially contaminated cooling water from chemical separations activities.

Riparian - Situated or dwelling on the bank of a river or other body of water.

routine radioactive release - Planned or scheduled release of radioactivity to the environment.

seepage basin - Excavation that receives wastewater. Insoluble materials settle out on the floor of the basin and soluble materials seep with the water through the soil column, where they are removed partially by ion exchange with the soil. Construction may include dikes to prevent overflow or surface runoff.

sensitivity - Capability of methodology or instruments to discriminate between samples with differing concentrations or containing varying amounts of analyte.

settling basin - Temporary holding basin (excavation) that receives wastewater that subsequently is discharged.

sievert - The International System of Units (SI) derived unit of dose equivalent. It attempts to reflect the biological effects of radiation as opposed to the physical aspects, which are characterized by the absorbed dose, measured in gray. One sievert is equal to 100 rem.

Site stream - Any natural stream on the Savannah River Site. Surface drainage of the site is via these streams to the Savannah River.

SME - Subject Matter Expert. A person who is an expert in a particular area or topic

source - Point or object from which radiation or contamination emanates.

source check - Radioactive source (with a known amount of radioactivity) used to check the performance of the radiation detector instrument.

source term - Quantity of radioactivity (released in a set period of time) that is traceable to the starting point of an effluent stream or migration pathway.

spent nuclear fuel - Used fuel elements from reactors.

spike - Addition, to a blank sample, of a known amount of reference material containing the analyte of interest.

stable - Not radioactive or not easily decomposed or otherwise modified chemically.

stack - Vertical pipe or flue designed to exhaust airborne gases and suspended particulate matter.

standard deviation - Indication of the dispersion of a set of results around their average.

stormwater runoff - Surface streams that appear after precipitation.

Superfund - See Comprehensive Environmental Response, Compensation, and Liability Act (CERCLA).

supernate - Portion of a liquid above settled materials in a tank or other vessel.

surface water - All water on the surface of the earth, as distinguished from groundwater. 
$\mathbf{T}$

tank farm - Installation of interconnected underground tanks for storage of high-level radioactive liquid wastes.

temperature - Thermal state of a body, considered with its ability to communicate heat to other bodies.

terrestrial - Living or growing on the land.

thermoluminescent dosimeter (TLD) - Device used to measure external gamma radiation.

total dissolved solids - Dissolved solids and total dissolved solids are terms generally associated with freshwater systems; they consist of inorganic salts, small amounts of organic matter, and dissolved materials.

total phosphorus - May occasionally stimulate excessive or nuisance growths of algae and other aquatic plants when concentrations exceed $25 \mathrm{mg} / \mathrm{L}$ at the time of the spring turnover on a volume- weighted basis in lakes or reservoirs.

total suspended particulates - Refers to the concentration of particulates in suspension in the air, regardless of the nature, source, or size of the particulates.

transport pathway - Pathway by which a released contaminant is transported physically from its point of discharge to a point of potential exposure to humans. Typical transport pathways include the atmosphere, surface water, and groundwater.

transuranic waste - Solid radioactive waste containing primarily alpha-emitting elements heavier than uranium.

trend - General drift, tendency, or pattern of a set of data plotted over time.

turbidity - Measure of the concentration of sediment or suspended particles in solution.

\section{$\mathbf{U}$}

unspecified alpha and beta emissions - The unidentified alpha and beta emissions that are determined at each effluent location by subtracting the sum of the individually measured alpha-emitting (e.g., plutonium-239 and uranium 235) and beta- emitting (e.g., cesium-137 and strontium-90) radionuclides from the measured gross alpha and beta values, respectively.

utility water - Once-through non-contact cooling water, recirculated non-contact cooling water, boiler blowdown, steam condensate, air conditioning condensate, and other uncontaminated heating, ventilation and air conditioning or compressor condensates.

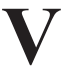

vitrify - Change into glass.

vitrification - Process of changing into glass.

volatile organic compounds - Broad range of organic compounds, commonly halogenated, that vaporize at ambient, or relatively low, temperatures (e.g., acetone, benzene, chloroform, methyl alcohol). 


\section{W}

waste management - The U.S. Department of Energy uses this term to refer to the safe, effective management of various kinds of nonhazardous, hazardous, and radioactive waste generated at Savannah River Site.

waste unit - An inactive area known to have received contamination or to have had a release to the environment.

water table - Planar, underground surface beneath which earth materials, such as soil or rock, are saturated with water.

weighting factor - Value used to calculate dose equivalents. It is tissue specific and represents the fraction of the total health risk resulting from uniform, whole-body irradiation that could be attributed to that particular tissue. The weighting factors used in this report are recommended by the International Commission on Radiological Protection (Publication 26).

wetland - Lowland area, such as a marsh, swamp, bog, Carolina bay, floodplain bottom, where land is covered by shallow water at least part of the year and is characterized by somewhat mucky soil.

worldwide fallout - Radioactive debris from atmospheric weapons tests that has been deposited on the earth's surface after being airborne and cycling around the earth. 


\section{REFERENCES}

ATSDR, 2012. Agency for Toxic Substances and Disease Registry, 2012. "Evaluation of Exposures to Contaminants in Biota Originating from the Savannah River Site (USDOE) Aiken, South Carolina EPA Facility ID: SC1890008989 February 29, 2012.” Department of Health and Human Services, Springfield, Virginia

Brisbin, 1989. Brisbin, I.L., Jr. "Radiocesium Levels in a Population of American Alligators: A Model for the Study of Environmental Contaminants in Free-Living Crocodilians." In Crocodiles: Proceedings of the 8th Working Meeting of the Crocodile Specialist Group of the Species Survival Commission of the International Union for Conservation of Nature and Natural Resources, IUCN. Quito, Ecuador

Brisbin, et al., 1992. Brisbin, I.L., Jr., J.M. Benner, L.A. Brandt, R.A. Kennamer, and T.M. Murphy. "Long-Term Population Studies of American Alligators Inhabiting a Reservoir: Initial Responses to Water Level Drawdown," p. 53-76. In Crocodiles - Proceedings of the 11th Working Meeting of the Crocodile Specialist Group of the SSC of the IUCN - The World Conservation Union, Vol. 1. IUCN. Victoria Falls, Zimbabwe

Brisbin, et al., 1997. Brisbin, I.L., K.F. Gaines, C.H. Jagoe, and P.A. Consolie. "Population Studies of A. Alligators (Alligator mississippiensis) Inhabiting a Reservoir: Responses to Long-Term Drawdown and Subsequent Refill," p. 446-477. In Proceedings of the 13th Working Meeting of the IUCN/SSC Crocodile Specialist Group, IUCN-The World Conservation Union. Gland, Switzerland

Carlton et al., 1994. Carlton, W.H., C.E. Murphy, Jr., and A.G. Evans, 1994, "Radiocesium in the Savannah River Site Environment," Health Physics, Volume 67, Number 3, Williams \& Wilkins, Baltimore, MD

Cherry, 2006. Cherry, G.S., 2006, "Simulation and Particle Tracking Analysis of Ground-Water Flow near the Savannah River Site, Georgia and South Carolina, 2002, and for Selected Ground-Water Management Scenarios, 2002 and 2020," Scientific Investigations Report, 2006-5195, U.S. Geological Survey, Reston, VA

DOE, 1988. U.S. Department of Energy, 1988, "External and Internal Dose Conversion Factors for Calculation of Dose to the Public," DOE/EH-0070 \& 71, Washington, DC

DOE, 2002. U.S. Department of Energy, 2002, “A Graded Approach for Evaluating Radiation Doses to Aquatic and Terrestrial Biota,” DOE Standard, DOE-STD-1153-2002, July 2002, Washington, DC

DOE, 2011. U.S. Department of Energy, 2011, "Radiation Protection of the Public and the Environment," DOE Order 458.1, Change 2; Washington, DC

DOE, 2011a. U.S. Department of Energy, 2011, "DOE Derived Concentration Technical Standard," DOESTD-1196-2011, Washington, DC

Eddy et al., 2012. Eddy, T., B. Terry, A. Meyer, J. Hall, P. Allen, D. Hughey, and T. Hartley, "Use of Remote Technology in the Surface Water Environmental Monitoring Program at SRS Reducing Measurements in the Field," SRNSSTI-2013-00077, Conference Proceedings, WM2013 Conference, Phoenix, AZ, February 24-28, 2013

EPA, 1989. U.S. Environmental Protection Agency, 1989, "National Priorities List for Uncontrolled Hazardous Waste Sites," Federal Register, Volume 54, Number 223, November 21, pp. 48184-48189, Washington, DC

EPA, 1989a. U.S. Environmental Protection Agency, 1989, "National Emission Standards for Hazardous Air Pollutants," Title 40 Code of Federal Regulations, Part 61, Appendix D, August 1989, Washington, DC 
EPA, 1993. U.S. Environmental Protection Agency, 1993, "External Exposure to Radionuclides in Air, Water, and Soil, Federal Guidance Report No. 12" (USEPA 402-R-93-081), Washington, DC

EPA, 1999. U.S. Environmental Protection Agency, 1999, "Cancer Risk Coefficients for Environmental Exposure to Radionuclides," Federal Guidance Report No.13, USEPA 402-R-99-001, September 1999, Washington, DC

EPA, 2000. U.S. Environmental Protection Agency, 2000, "National Primary Drinking Water Regulations," Title 40 Code of Federal Regulations, Part 141, September 2002, Washington, DC

EPA, 2002. U.S. Environmental Protection Agency, 2012, "National Emission Standards for Hazardous Air Pollutants," Title 40 Code of Federal Regulations, Part 61, Subpart H, July 2002, Washington, DC

EPA, 2002a. U.S. Environmental Protection Agency, 2002, "National Emission Standards for Hazardous Air Pollutants," Title 40 Code of Federal Regulations, Part 61, Subpart H, September 2002, Washington, DC

EPA, 2011. U.S. Environmental Protection Agency, 2011, "Exposure Factor Handbook," USEPA, October 2011, Washington, DC

FFA, 1993. Federal Facility Agreement for the Savannah River Site, 1993, Administrative Docket Number 89-05-FF, August 16, 1993, WSRC-OS-94-42, Savannah River Site, Aiken, SC

Friday, 1996. Friday, G.P. Radiological Bioconcentration Factors for Aquatic, Terrestrial and Wetland Ecosystems at the Savannah River Site, WSRC-TR-96-0231, 1996, Savannah River Site, Aiken, SC

GA DNR, 2013. Georgia Department of Natural Resources, 2012, “Alligator Hunting Season for 2012.” Web site: http://www.georgiawildlife.com/Hunting/Alligator, Atlanta, GA

ICRP, 1996. Annals of the ICRP, 1996, Publication 72, "Age-Dependent Doses to Members of the Public from Intake of Radionuclides: Part 5 Compilation of ingestion and Inhalation Dose Coefficients," International Commission on Radiological Protection, 26(1), Stockholm, Sweden

ICRP, 2002. International Commission on Radiation Protection, 2002. Basic Anatomical and Physiological Data for Use in Radiological Protection: Reference Values, Publication 89, Elmsford, NY

ICRP, 2006. International Commission on Radiation Protection, 2006. Assessing Dose of the Representative Person for the Purpose of Radiation Protection of the Public and the Optimization of Radiological Protection, Publication 101, Elmsford, NY

Jagoe, et al., 1998. Jagoe, C.H., B. Arnold-Hill, G.M. Yanochko, P.V. Winger, and I.L. Brisbin, Jr. "Mercury in alligators (Alligator mississippiensis) in the southeastern United States," p. 255-262. In International Conference on Mercury as a Global Pollutant, The Science of the Total Environment. Hamburg, Germany.

Jannik et al., 2010. Jannik, G.T., D.L Karapatakis, P.L. Lee, E.B. Farfan, 2010, Land and Water Use Characteristics and Human Health Input Parameters for use in Environmental Dosimetry and Risk Assessments at the Savannah River Site, SRNL-STI-2010-00447, Savannah River National Laboratory, Aiken, SC

Jannik et al, 2011. Jannik, G.T. and R. Scheffler, Critical Radionuclide and Pathway Analysis for the Savannah River Site, SRNS-STI-2011-00503, Rev. 0, August 2011, Savannah River Site, Aiken, SC

NRC, 1977. U.S. Nuclear Regulatory Commission, 1977, Regulatory Guide 1.109, "Calculation of Annual Doses to Man from Routine Releases of Reactor Effluents for the Purpose of Evaluating Compliance with 10 CFR 50," Appendix I, Revision 1, Washington, DC

SCDHEC, 2008. South Carolina Department of Health and Environmental Control, 2008, "Water Classifications and Standards," South Carolina Code of Regulations, R.61-68, Columbia, SC 
SCDHEC, 2010. South Carolina Department of Health and Environmental Control, 2010, "South Carolina Mercury Assessment and Reduction Initiative," Columbia, SC

SCDHEC, 2012. South Carolina Department of Health and Environmental Control, 2012, "South Carolina 2012 Fish Consumption Advisories," Columbia, SC

SCDNR, 2013. South Carolina Department of Natural Resources, 2013, Website: http://dnr.sc.gov/wildlife/alligator/ "Alligator Hunting Season Report 2012," Report 12-05. South Carolina Department of Natural Resources, Columbia, SC

SRARP, 2012. Savannah River Archaeological Research Program, 2012, Annual Review of Cultural Resources Investigations by the Savannah River Archaeological Research Program, Fiscal Year 2012, South Carolina Institute of Archaeology and Anthropology, University of South Carolina, Columbia, SC

SREL, 2013. Savannah River Ecology Laboratory, 2012, “American Alligator,” SREL Outreach Program Factsheet. http://www.srel.edu/outreach/factsheet/AlligatorBrochure.pdf, Savannah River Site, Aiken, SC

SRNS, 2010. Savannah River Nuclear Solutions, LLC, 2010, Savannah River Site Environmental Report for 2010, SRNS-STI-2011-00059, Savannah River Site, Aiken, SC

SRNS, 2011. Savannah River Nuclear Solutions, LLC, 2011, Savannah River Site Environmental Report for 2011, SRNS-STI-2012-00200, Savannah River Nuclear Site, Aiken, SC

SRNS, 2011a. Savannah River Nuclear Solutions, LLC, 2011, Savannah River Site Groundwater Management Strategy and Implementation Plan, WSRC-RP-2006-4074, Savannah River Site, Aiken, SC

SRNS, 2012. Savannah River Nuclear Solutions, LLC, 2012, Savannah River Site Groundwater Protection Program, SRNS-TR-2009-00076, Revision 2, Savannah River Site, Aiken, SC

SRNS, 2012a. Savannah River Nuclear Solutions, LLC, 2012, Focused Corrective Measures Study/Feasibility Study Report (CMS/FS) for the Wetland Area at Dunbarton Bay in Support of the Steel Creek Integrator Operable Unit, SRNS-RP-2012-00252, Savannah River Site, Aiken, SC

SRS Data, 1995. Savannah River Site Environmental Protection Department, 1995, Savannah River Site Environmental Data for 1994, WSRC-TR-95-077, Savannah River Site, Aiken, SC

SRS EDAM, 2010. Savannah River National Laboratory, 2010, Environmental Dose Assessment Manual, SRNLTR-2010-00274, Revision 0, Savannah River National Laboratory, Aiken, SC

SRS EM Plan, 2013. Savannah River Nuclear Solutions, LLC, 2013, "Savannah River Site Environmental Monitoring Program Management Plan,” SRS Manual 3Q1-101, Revision 3, Savannah River Site, Aiken, SC

SRS EM QA Plan, 2013. Savannah River Nuclear Solutions, LLC, 2013, "Savannah River Site Environmental Monitoring Program Quality Assurance Project Plan," SRS Manual 3Q1-102, Revision 1, Savannah River Site, Aiken, SC

SRS EP, 2013. Savannah River Nuclear Solutions, LLC, 2013, SRS Manual SCD-7, SRS Emergency Plan, Savannah River Site, Aiken, SC

Stone and Jannik, 2013. Stone, D.K. and G.T. Jannik, 2013, Site Specific Reference Person Parameters and Derived Concentration Standards for the Savannah River Site, 2013, SRNL-STI-2013-00115, Savannah River National Laboratory, Aiken, SC

Yu et al., 2001. C. Yu, A.J. Zielen, J.J. Cheng, D.J. LePoire, E. Gnanapragasam, S. Kamboj, Amish, A. Wallo III, W.A. Williams, and H. Peterson, "Users' Manual for RESRAD Version 6," Argonne National Laboratory Report, ANL/ EAD/4, July 2001, Argonne, IL 


\begin{tabular}{|c|c|c|c|}
\hline \multicolumn{4}{|c|}{ Units of Measure } \\
\hline Symbol & Name & Symbol & Name \\
\hline Temperature & 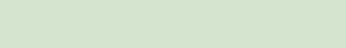 & & \\
\hline${ }^{\circ} \mathrm{C}$ & degrees Centigrade & ppb & parts per billion \\
\hline${ }^{\circ} \mathrm{F}$ & degrees Fahrenheit & ppm & parts per million \\
\hline Time & & Rate & \\
\hline d & day & cfs & cubic feet per second \\
\hline $\mathrm{h}$ & hour & gpm & gallons per minute \\
\hline $\mathrm{y}$ & year & & \\
\hline & & Conductivity & \\
\hline Length & & $\mu \mathrm{mho}$ & micromho \\
\hline $\mathrm{cm}$ & centimeter & & \\
\hline $\mathrm{ft}$ & foot & Radioactivity & \\
\hline in & inch & $\mathrm{Ci}$ & curie \\
\hline $\mathrm{km}$ & kilometer & cpm & counts per minute \\
\hline $\mathrm{m}$ & meter & $\mathrm{mCi}$ & millicurie \\
\hline $\mathrm{mm}$ & millimeter & $\mu \mathrm{Ci}$ & microcurie \\
\hline$\mu \mathrm{m}$ & micrometer & $\mathrm{pCi}$ & picocurie \\
\hline & & $\mathrm{Bq}$ & becquerel \\
\hline Mass & & & \\
\hline $\mathrm{g}$ & gram & Radiation Dose & \\
\hline $\mathrm{kg}$ & kilogram & $\operatorname{mrad}$ & millirad \\
\hline $\mathrm{mg}$ & milligram & mrem & millirem \\
\hline$\mu \mathrm{g}$ & microgram & $\mathrm{Sv}$ & sievert \\
\hline & & $\mathrm{mSv}$ & millisievert \\
\hline Area & & $\mu \mathrm{Sv}$ & microsievert \\
\hline $\mathrm{mi}^{2}$ & square mile & $\mathrm{R}$ & roentgen \\
\hline $\mathrm{ft}^{2}$ & square foot & $\mathrm{mR}$ & milliroentgen \\
\hline & & $\mu \mathrm{R}$ & microroentgen \\
\hline Volume & & Gy & gray \\
\hline gal & gallon & & \\
\hline $\mathrm{L}$ & liter & & \\
\hline $\mathrm{mL}$ & milliliter & & \\
\hline
\end{tabular}




\section{Fractions and Multiples Units}

\begin{tabular}{|crlcc|}
\hline Multiple & Decimal Equivalent & Prefix & Symbol & Report Format \\
$10^{6}$ & $1,000,000$ & mega- & $\mathrm{M}$ & $\mathrm{E}+06$ \\
$10^{3}$ & 1,000 kilo- & $\mathrm{k}$ & $\mathrm{E}+03$ \\
$10^{2}$ & 100 hecto- & $\mathrm{h}$ & $\mathrm{E}+02$ \\
10 & 10 deka- & $\mathrm{da}$ & $\mathrm{E}+01$ \\
$10^{-1}$ & 0.1 deci- & $\mathrm{da}$ & $\mathrm{E}-01$ \\
$10^{-3}$ & 0.001 milli- & $\mathrm{m}$ & $\mathrm{E}-03$ \\
$10^{-6}$ & 0.000001 micro- & $\mu$ & $\mathrm{E}-06$ \\
$10^{-9}$ & 0.000000001 nano- & $\mathrm{n}$ & $\mathrm{E}-09$ \\
$10^{-12}$ & 0.000000000001 pico- & $\mathrm{p}$ & $\mathrm{E}-12$ \\
$10^{-15}$ & 0.000000000000001 femto- & $\mathrm{f}$ & $\mathrm{E}-15$ \\
$10^{-18}$ & 0.000000000000000001 & atto- & $\mathrm{a}$ & $\mathrm{E}-18$ \\
\hline
\end{tabular}

\begin{tabular}{|lll|}
\hline \multicolumn{3}{|c|}{ Conversion Table (Units of Radiation Measure) } \\
\hline Current System & Systeme International & Conversion \\
curie (Ci) & becquerel (Bq) & $1 \mathrm{ci}=3.7 \times 10^{10}$ \\
rad (radiation absorbed dose) & gray (Gy) & $1 \mathrm{rad}=0.01 \mathrm{~Gy}$ \\
rem (roentgen equivalent man) & sievert (Sv) & $1 \mathrm{rem}=0.01 \mathrm{~Sv}$ \\
\hline
\end{tabular}

\begin{tabular}{|lll|lll|}
\hline \multicolumn{5}{c|}{ Conversion Table } \\
\hline Multiply & By & To Obtain & Multiply & By & To Obtain \\
in & 2.54 & $\mathrm{~cm}$ & $\mathrm{~cm}$ & 0.394 & $\mathrm{in}$ \\
$\mathrm{ft}$ & 0.305 & $\mathrm{~m}$ & $\mathrm{~m}$ & 3.28 & $\mathrm{ft}$ \\
$\mathrm{mi}$ & 1.61 & $\mathrm{~km}$ & $\mathrm{~km}$ & 0.621 & $\mathrm{mi}$ \\
$\mathrm{lb}$ & 0.4536 & $\mathrm{~kg}$ & $\mathrm{~kg}$ & 2.205 & $\mathrm{lb}$ \\
$\mathrm{liq}$ qt-US & 0.945 & $\mathrm{~L}$ & 1 & 1.057 & $\mathrm{liq} \mathrm{qt}-\mathrm{US}$ \\
$\mathrm{ft}^{2}$ & 0.093 & $\mathrm{~m}^{2}$ & $\mathrm{~m}^{2}$ & 10.764 & $\mathrm{ft}^{2}$ \\
$\mathrm{mi}^{2}$ & 2.59 & $\mathrm{~km}^{2}$ & $\mathrm{~km}^{2}$ & 0.386 & $\mathrm{mi}^{2}$ \\
$\mathrm{ft}^{3}$ & 0.028 & $\mathrm{~m}^{3}$ & $\mathrm{~m}^{3}$ & 35.31 & $\mathrm{ft}^{3}$ \\
$\mathrm{~d} / \mathrm{m}$ & 0.450 & $\mathrm{pCi}$ & $\mathrm{pCi}$ & 2.22 & $\mathrm{~d} / \mathrm{m}$ \\
$\mathrm{pCi}$ & $10^{-6}$ & $\mu \mathrm{Ci}$ & $\mu \mathrm{Ci}$ & $10^{6}$ & $\mathrm{pCi}$ \\
$\mathrm{pCi} / \mathrm{L}$ (water) & $10^{-9}$ & $\mu \mathrm{Ci} / \mathrm{mL}$ (water) & $\mathrm{uCi} / \mathrm{mL}$ (water) & $10^{9}$ & $\mathrm{pCi} / \mathrm{L}$ (water) \\
$\mathrm{pCi} / \mathrm{m}^{3}$ (air) & $10^{-12}$ & $\mu \mathrm{Ci} / \mathrm{mL}$ (air) & $\mu \mathrm{Ci} / \mathrm{mL}$ (air) & $10^{12}$ & $\mathrm{pCi} / \mathrm{m}^{3}$ (air) \\
\hline
\end{tabular}


This page intentionally left blank. 

enterprise-Srs 